San Jose State University

SJSU ScholarWorks

Master's Theses

Master's Theses and Graduate Research

1997

\title{
Geology and hydrogeology of the George Air Force Base vicinity, California
}

Shiela Marie Chrisley

San Jose State University

Follow this and additional works at: https://scholarworks.sjsu.edu/etd_theses

\section{Recommended Citation}

Chrisley, Shiela Marie, "Geology and hydrogeology of the George Air Force Base vicinity, California" (1997). Master's Theses. 1563.

DOI: https://doi.org/10.31979/etd.xssq-d5cy

https://scholarworks.sjsu.edu/etd_theses/1563

This Thesis is brought to you for free and open access by the Master's Theses and Graduate Research at SJSU ScholarWorks. It has been accepted for inclusion in Master's Theses by an authorized administrator of SJSU ScholarWorks. For more information, please contact scholarworks@sjsu.edu. 


\section{INFORMATION TO USERS}

This manuscript has been reproduced from the microfilm master. UMI films the text directly from the original or copy submitted. Thus, some thesis and dissertation copies are in typewriter face, while others may be from any type of computer printer.

The quality of this reproduction is dependent upon the quality of the copy submitted. Broken or indistinct print, colored or poor quality illustrations and photographs, print bleedthrough, substandard margins, and improper alignment can adversely affect reproduction.

In the unlikely event that the author did not send UMI a complete manuscript and there are missing pages, these will be noted. Also, if unauthorized copyright material had to be removed, a note will indicate the deletion.

Oversize materials (e.g., maps, drawings, charts) are reproduced by sectioning the original, beginning at the upper left-hand corner and continuing from left to right in equal sections with small overlaps. Each original is also photographed in one exposure and is included in reduced form at the back of the book.

Photographs included in the original manuscript have been reproduced xerographically in this copy. Higher quality 6 " $\times 9$ " black and white photographic prints are available for any photographs or illustrations appearing in this copy for an additional charge. Contact UMI directly to order.

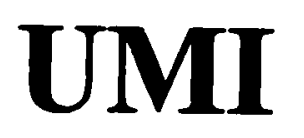

A Bell \& Howell Information Company 
GEOLOGY AND HYDROGEOLOGY OF THE

GEORGE AIR FORCE BASE VICINITY, CALIFORNIA

\author{
A Thesis \\ Presented to \\ The Faculty of the Department of Geology \\ San Jose State University \\ In Partial Fulfillment \\ of the Requirement of the Degree \\ Master of Science
}

by

Shiela Marie Chrisley

December 1997 
UMI Number: 1388181

UMI Microform 1388181

Copyright 1998, by UMI Company. All rights reserved.

This microform edition is protected against unauthorized copying under Title 17, United States Code.

\section{UMI \\ 300 North Zeeb Road \\ Ann Arbor, MI 48103}


(C) 1997

Shiela Marie Chrisley

ALL RIGHTS RESERVED 
APPROVED FOR THE DEPARTMENT OF GEOLOGY

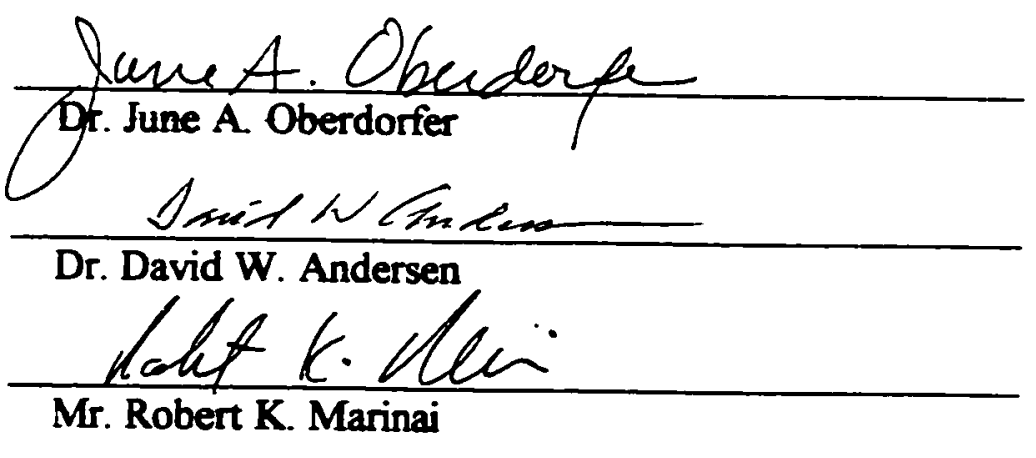

APPROVED FOR THE UNIVERSITY

William Fish en 


\section{ABSTRACT \\ GEOLOGY AND HYDROGEOLOGY OF THE GEORGE AIR FORCE BASE VICINITY, CALIFORNIA \\ by Shiela M. Chrisley}

An existing hydrogeologic model of George Air Force Base near Victorville, California suggests a 3-layer system consisting of two alluvial units separated by a finegrained aquitard. Examination of soil cores, drilling $\log s_{2}$ and chemical and geotechnical data, in addition to thin section point counting and X-Ray diffractometric (XRD) testing, generally support the existing model. Chemical and geotechnical data indicate that the two alluvial units are likely from different source areas, which likely explains the hydrogeologic and chemical differences observed between the area's two aquifers. Sediment composition indicates that the shallowest alluvial unit may not belong to the Victorville Fan, as is suggested by the existing model. Clay minerals and the absence of evaporite minerals suggest the aquitard is likely of lacustrine origin. Evidence from soil cores and point counting results indicate that the aquitard, depicted as a continuous unit in the existing model, may be offset approximately 100-150 feet in the southeastern portion of the base. 


\section{DEDICATION}

To my parents, John and Cathy, who have supported all my accomplishments through their inspiration and loving support. To my sister Jackie, who knows in her heart of hearts that she can accomplish anything she sets her mind to. See? It only boils down to a pile of paper. It is the getting there that means everything. To my husband, Greg, who suffered through it all without a complaint. 


\section{TABLE OF CONTENTS}

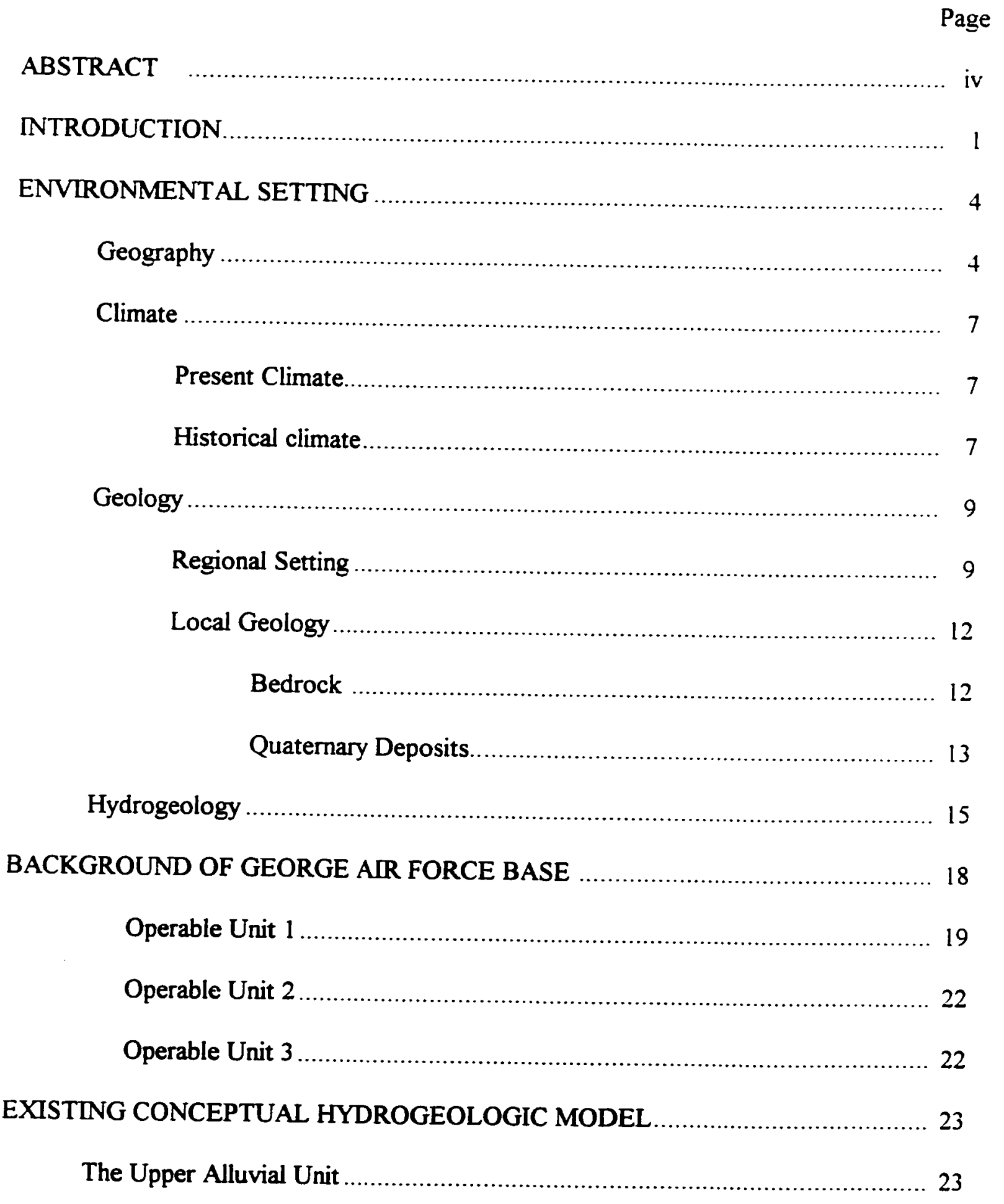




\section{TABLE OF CONTENTS (cont.)}

The Perched Aquifer

The Aquitard

The Lower Alluvial Unit

The Regional Aquifer

OBJECTIVES OF THIS STUDY

METHODS.

Review of Existing Data

Fieldwork

X-Ray Diffractometric Testing

Sample Preparation.

Glycolation and Heating

Testing Parameters

Data Presentation and Interpretation ........................................... 43

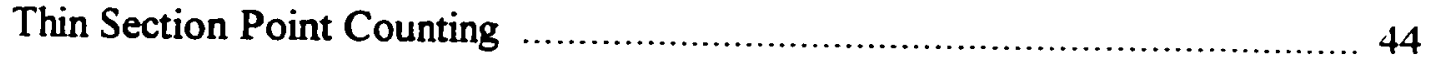

Thin Section Preparation ....................................................... 45

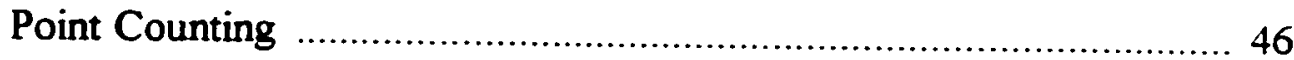

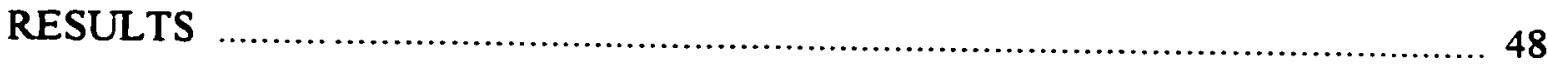

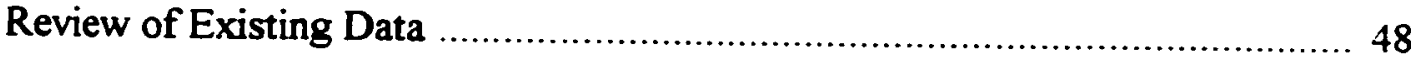

Borehole Logs and Soil Cores ....................................................... 48 


\section{TABLE OF CONTENTS (cont.)}

\begin{tabular}{|c|c|}
\hline & Page \\
\hline Geotechnical Information... & 58 \\
\hline Aquifer Testing Data .......... & 61 \\
\hline Water Levels. & $\ldots 67$ \\
\hline Water Quality. & 72 \\
\hline
\end{tabular}

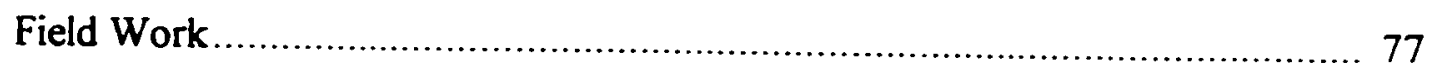

Results of X-Ray Diffactometric Testing .............................................. 80

Results of Thin Section Point Counting ….......................................... 84

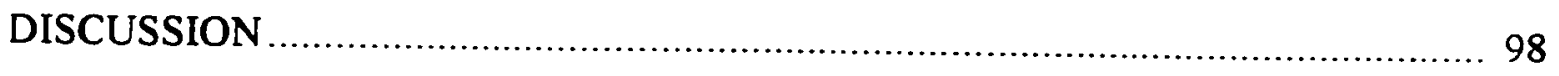

Extent of the Aquitard and its Configuration in the Southeastern

Portion of GAFB

Quantifiable Differences in Water Quality and Hydrogeologic

Characteristics

Age and Origin of Sediments

\section{APPENDICES}

A - Lithologic and geophysical logs for boreholes RZ-01 through RZ-04

B - X-Ray diffraction graphs

C - Thin section point counting data sheets 


\section{LIST OF ILLUSTRATIONS}

Figure

Page

I Vicinity Map for George Air Force Base

2 Major Hydrogeologic Features in the Mojave River Basin.

3 Mojave River Bluffs East of George Air Force Base.

4 Map of Regional Faults and Physiography

5 George Air Force Base Operable Unit Site Locations

6 Map of the OU 1 TCE Plume.

7 Simplified Conceptual Hydrogeologic Model of George Air Force Base

8 Cross Section A-A'

9 Cross Section B-B'

10 Groundwater Elevations in the Perched Aquifer, May 1996

11 Map of the Aquitard Surface

12 Aquitard Thickness

13 Silt and Clay Portions of the Aquitard

14 Groundwater Elevations in the Regional Aquifer, May 1996

15 Locations of "RZ" Boreholes

16 Cross-Section From Wells on and Near George Air Force Base

17 Cross-Section From Wells South of George Air Force Base

18 Cross-Section From Wells North, East, and West of George Air Force Base

19 Interpreted Regional Extent and Surface of the Aquitard 


\section{LIST OF ILLUSTRATIONS (cont.)}

Figure

20 Interpreted Thickness of the Aquitard

21 Coefficient of Uniformity Versus Vertical Hydraulic Conductivity for

Perched and Regional Aquifer Sediments

22 Hydraulic Conductivity for the Regional Aquifer

23 Hydraulic Conductivity for the Perched Aquifer ............................................ 64

24 Hydrographs for Selected Regional Aquifer Wells ..................................6 68

25 Hydrographs for Selected Perched Aquifer Wells .................................... 70

26 Comparison of Metals Concentrations in the Perched and Regional Aquifers

27 Stiff Diagrams for the Regional and Perched Aquifers ............................ 75

28 Piper Diagram for Regional and Perched Aquifers .................................. 78

29 Geologic Map of the George Air Force Base Vicinity ................................ 78

30 XRD Patterns for Unwetted, Crushed Samples...................................... 81

31 Triangular Plots of Thin Section Point Counting Results.............................. 86

32 Comparison of Upper and Lower Alluvial Unit Sand Compositions .............. 87

33 Thin Section of Single- and Poly-Crystalline Quartz Grains and Undulose Extinction in Quartz.

34 Thin Section of Unaltered and Altered Feldspar Grains............................ 90

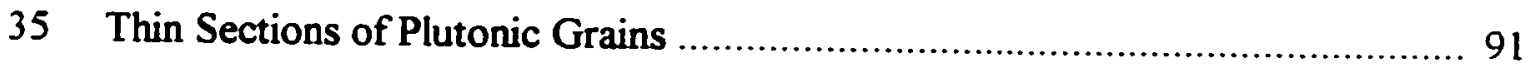

36 Thin Section of Volcanic Clast in Lower Alluvial Unit ................................ 92 


\section{LIST OF ILLUSTRATIONS (cont.)}

Figure

Page

37 Thin Section of Metamorphic or Metavolcanic Grain 93

38 Thin Section of Chert and Dolomite Grains 94

39 Thin Section of Accessory Mineral with High Birefringence 95

40 Schematic Representation of Deposition and Faulting of the Aquitard 102 


\section{LIST OF TABLES}

Table

Page

1 Summary of Samples Tested Using X-Ray Diffractometric Testing ................. 41

2 Summary of Samples Tested Using Thin Section Point Counting ................... 45

3 Aquitard and Groundwater Elevations in 'RZ" Boreholes .......................... 49

4 Geotechnical Information Summary for Water-Bearing Sediment ................. 59

5 Summary of Aquifer Test Results, George Air Force Base ......................... 62

6 Background Concentrations of Selected Constituents in Groundwater, George Air Force Base

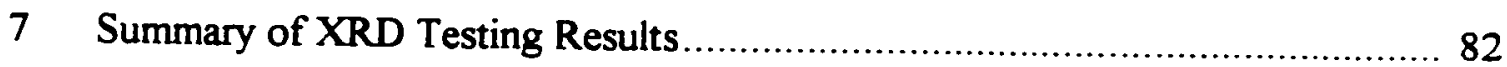

8 Summary of Thin Section Point Counting Results................................... 85 


\section{INTRODUCTION}

George Air Force Base (GAFB) occupies approximately 5,350 acres within the arid Mojave Desert Physiographic Province of Califormia. The base is situated in the Victor Valley just northwest of the city of Victorville and east of Adelanto (Fig. 1). The vicinity of GAFB is underlain by a complex system of alluvial fan, lacustrine, and fluvial deposits, including recent deposits of the Mojave River, which flows just east of GAFB. Three aquifers a perched aquifer, a regional aquifer, and the Mojave River alluvial aquifer - occupy the sediments of the vicinity.

As the protection of limited groundwater resources becomes increasingly important to the desert community of the Victor Valley, local water resource agencies have undertaken a number of studies to investigate groundwater conditions in the vicinity. In addition, a significant amount of hydrogeologic information has been gathered by numerous consultants studying environmental conditions at GAFB, where previous military activities resulted in groundwater contamination by fuel and industrial solvents such as trichloroethene (TCE). Efforts to remediate the groundwater contamination beneath GAFB are presently underway.

To date, much of the hydrogeologic information collected in the Victorville area has been incorporated into broadly based regional studies (Bookman-Edmonston Engineering, Inc., 1994; Boyle Engineering Corp., 1988; Hardt, 1971). At the other end of the spectrum, the information collected for environmental investigations at GAFB has 


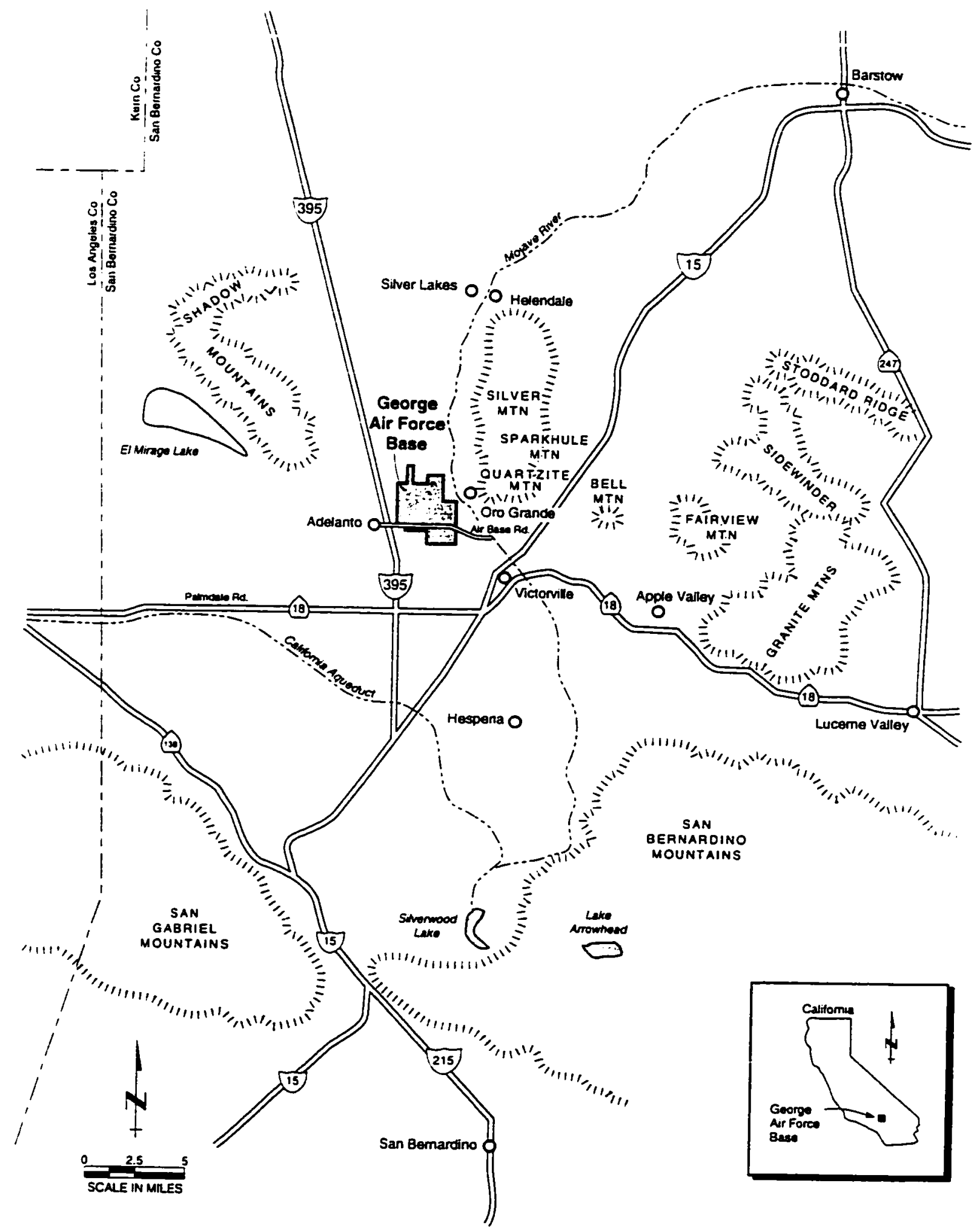
1995).

Figure 1. Vicinity map for George Air Force Base (from Montgomery Watson. 
been used on a very focused basis, primarily as it relates to the study and remediation of soil and groundwater contamination (IT Corp., 1992; JMM, 1992; Montgomery Watson, 1995).

The intent of this thesis is to evaluate the existing conceptual hydrogeologic model formulated for GAFB. This model was compiled by Montgomery Watson (1995), an environmental engineering-consulting firm in Walnut Creek, CA. Montgomery Watson has been providing investigative and remediation services at GAFB since 1986. The author is employed by Montgomery Watson and has worked on the GAFB project and site model formulation. It was during these activities that the author identified several areas of interest for further investigation. 


\section{ENVIRONMENTAL SETTING}

\section{Geography}

The geography of the eastern Mojave Desert varies from elevated mountain environs to low desert basins. Regional elevations range from approximately 8,500 feet above mean sea level (msl), near the headwaters of the Mojave River in the San Bernardino Mountains, to 923 feet msl at the Mojave River terminus at Soda Dry Lake, approximately 85 miles northeast of GAFB (Fig. 2). The topographic relief in the GAFB vicinity of the Victor Valley is dominated by a gently northward-sloping alluvial fan derived from the San Bernardino and San Gabriel Mountains approximately 15 miles south of the base. Numerous small mountain ranges exist locally, including a small unnamed range approximately 1 mile east of GAFB.

Local elevations range from 4,532 feet msl atop Quartzite Mountain east of the base to 2,600 feet along the Mojave River channel. Elevations at GAFB range from 2,650 feet msl at the northeast corner of the base to 2,920 feet at the southwest corner. The average elevation at GAFB is approximately 2,750 feet msl with slopes of approximately 2 to 4 percent toward the northeast. The base topography is relatively flat except along the eastem boundary, where elevations drop approximately 200 feet to the Mojave River channel. Bluffs have formed along the western side of the channel, locally exposing up to 100 feet of sediment (Fig. 3). 


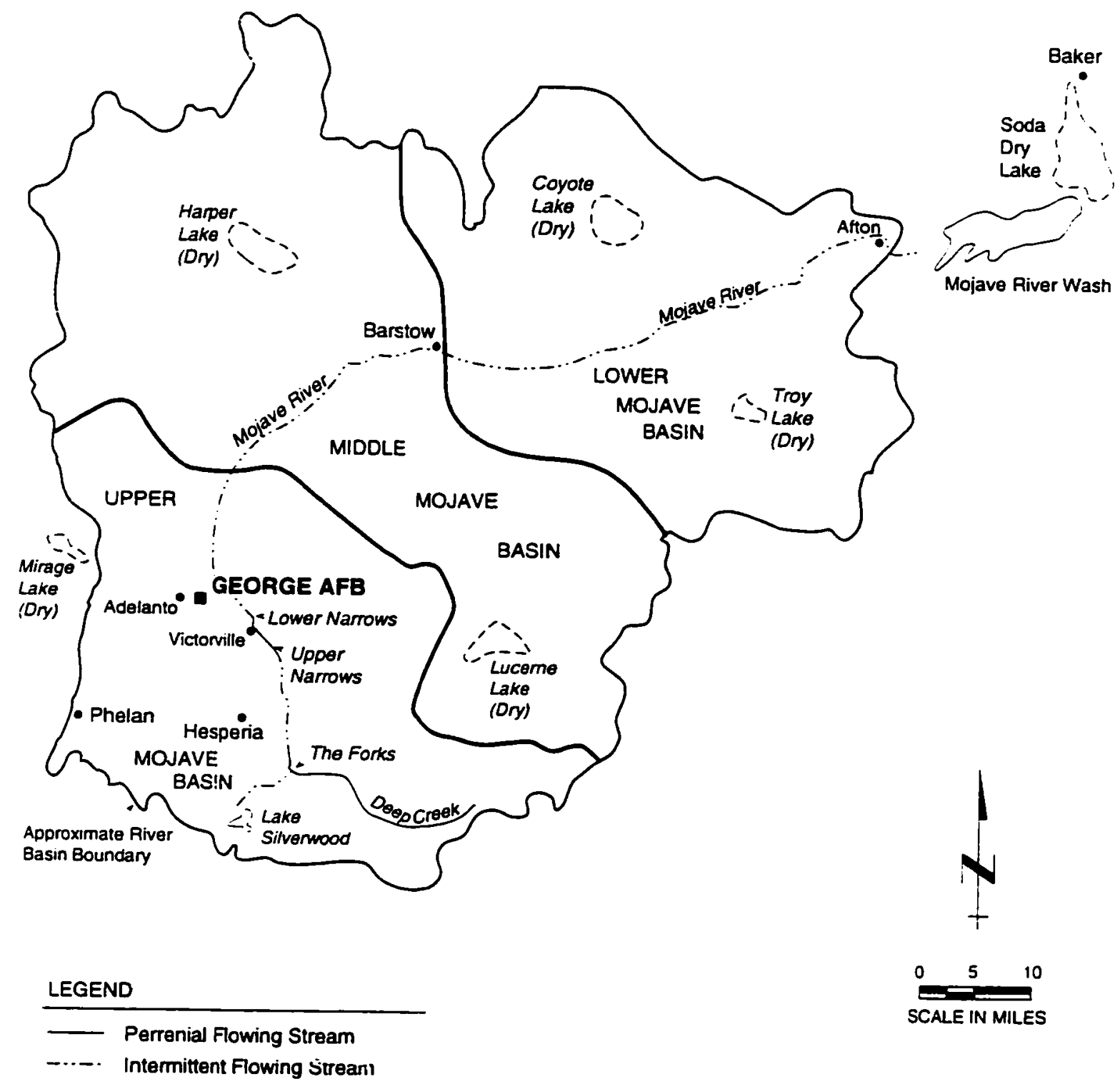

Figure 2. Major hydrogeologic features in the Mojave River Basin (from Montgomery Watson, 1995). 


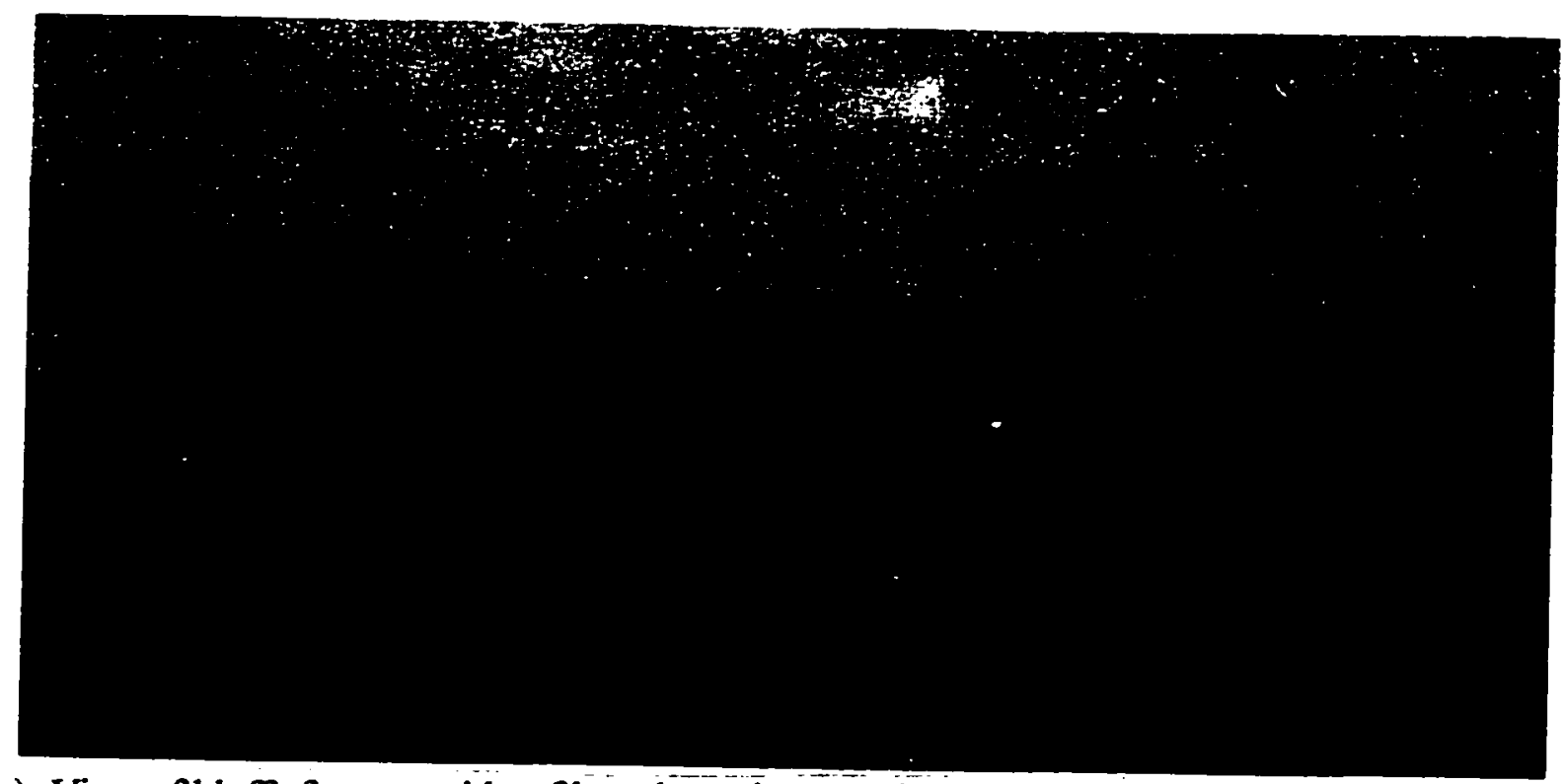

(a) View of bluffs from outside of base boundary northeast of housing area; looking north. Upper Alluvial Unit forms the prominent bluffs. Green vegetation on right-handside of the photo is the Mojave River Channel, roughly $1 / 2$ mile in the distance.

(b) View from top of bluffs on base property, looking east toward cement plant and town of Oro Grande. Quartzite Mountain is in the background. Mojave River Channel, containing green vegetation, is in the middle of the photo. The bluffs are formed by the Upper Alluvial Unit. Beds are essentially horizontal.

Figure 3. Mojave River bluffs east of George Air Force Base. 


\section{Climate}

\section{Present Climate}

The study area is located close to the transitional zone between the tropical desert and the continental desert (McNeil, 1963). The climate of the GAFB area is characterized by extremely hot, dry summers, with maximum daily temperatures often exceeding $100^{\circ} \mathrm{F}$ in July and August. Winters are cool and dry and evening temperatures often fall below freezing in December and January. The annual average temperature is $62^{\circ} \mathrm{F}$ (Montgomery Watson, 1995).

Annual precipitation in the Victor Valley area ranges from 0.77 inches to 11.22 inches, with an average annual precipitation of 5.1 inches (Umari et al., 1993). The majority of precipitation occurs between January and March. The average annual potential evapotranspiration rate throughout most of the area is about 83 inches (Science Applications International Corp., 1987), far exceeding average annual precipitation.

\section{Historical Climate}

Research in the Mojave Desert indicates that the climate of the area was previously much wetter than it is today. Perennial lakes occupied numerous basins throughout the region, not only during late Pleistocene, but also for brief intervals during the middle and late Holocene (Enzel et al., 1990). Ephemeral lakes have filled local playas in the vicinity of GAFB at least eight times during recent history and formed as a result of heavy winter 
storms in the headwaters of the Mojave River in the San Bernardino Mountains (Enzel et al., 1990). Mammalian fossils from local fine-grained sediments indicate that mammoth, horse, camel, and other grazers lived in this area approximately 500,000 years ago (Jefferson, 1986).

The wettest climatic period impacting the region is believed to have occurred approximately 11,000 years ago during the late Pleistocene. During this time, the Mojave River locally re-exposed older, deeper sediments and bedrock along its course. With the return of dryer conditions, downcutting ceased and deposition re-commenced along the river, resulting in the present braided channel (Wells, 1989).

The rise of the San Bernardino and San Gabriel Mountains along the San Andreas fault during the early Pleistocene ultimately accompanied a change in regional drainage from southward to northward, providing the source of the Mojave River and the Victorville Fan (Meisling, 1984). The San Gabriel and San Bernardino Mountains presented barriers to Pacific storms moving northward, ultimately creating the arid climate of today's Mojave Desert. Surface water drainage now terminates in closed dry lakes in the desert basins. 


\section{Geology}

\section{Regional Setting}

The Mojave Desert lies at the southwestern extent of Precambrian continental North America at the present plate edge formed by the San Andreas fault. This western edge of North America has faced an oceanic plate since the late Precambrian. As a result, the Mojave Desert area has been exposed to many types of continental tectonic influences over the last 600 million years, and has been described as one of the most geologically diverse and complex regions in the southwestern North American Cordillera (Glazner et al., 1994).

The western Mojave Desert is a wedge-shaped tectonic block, bordered on the north by the Garlock fault, on the south by the San Andreas fault, and on the east and west by rugged mountain ranges reaching elevations greater than 10,000 feet above sea level (Fig. 4). The block dips gently eastward in the study area (McNeil, 1963). The desert interior is characterized by an alluviated plain of low relief containing numerous undrained playas. Geophysical data indicate that Basin and Range-type normal faulting once played a dominant role in forming many of the bedrock basins in the Mojave Desert.

The uplift of surrounding mountain ranges likely occurred during the late Miocene and earty Pliocene. The Mojave Block is estimated to have risen 15,000 feet during the early Paleocene, with erosion keeping pace with much of the uplift (McNeil, 1963). Major faulting in these mountains likely began in the mid-Pliocene, with existing faults giving 


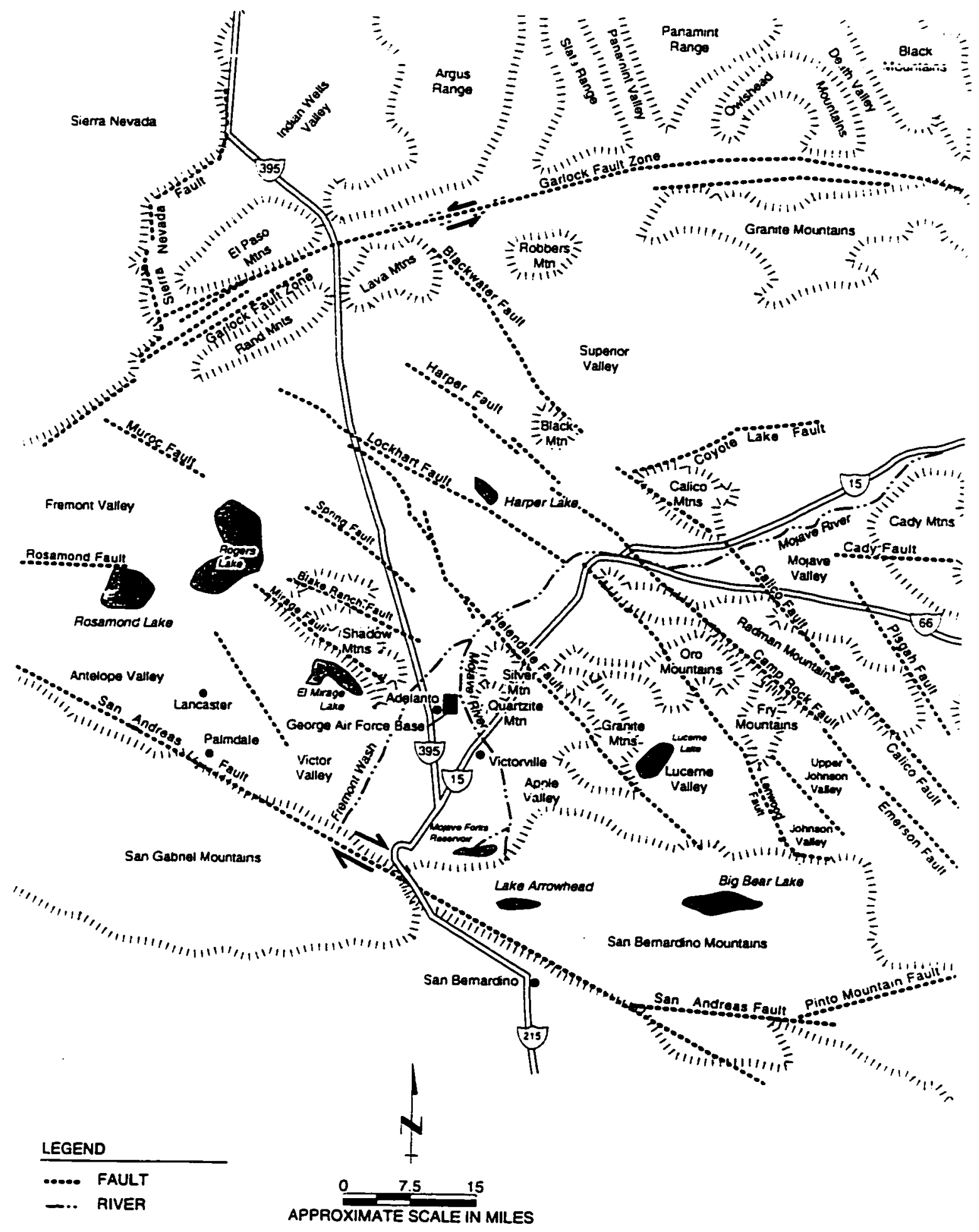

Figure 4. Map of regional faults and physiography (from Montgomery Watson. 1995). 
impetus to uplift and growth of local ranges. Movement along these major faults, including the San Andreas fault, the Helendale fault, and numerous smaller related faults, has continued into Holocene times.

Concurrent with the growth of the San Bernardino and San Gabriel Mountains in the late Tertiary and early Pleistocene, an integrated drainage system evolved. According to Meisling (1984), the ancestral Mojave River began introducing significant amounts of alluvium into the area during the middle Pleistocene, approximately 730,000 years to 500,000 years before present.

The terraces along the Mojave River provide evidence of at least three periods of deposition or three pauses in the erosional history of the river. The lacustrine clays exposed in the Mojave bluffs attest to the expansion of the lakes along the river in the Pleistocene, with glacial ages marked by the expansion of the lakes, and interglacials by their recession (McNeil, 1963). Fluctuations of climate from wet to dry are locally indicated by caliche deposits (McNeil, 1963).

Vertebrate fossils in the valley fill near Victorville are middle Pleistocene in age (approximately 500,000 years old and younger) (Jefferson, 1986). Other lithologic features including caliche-cemented fanglomerates, sandstones, and limey clays are interpreted to be the result of a more pluvial climatic regime than prevails in Holocene times (McNeil, 1963). 


\section{Local Geology}

Bedrock Precambrian rocks in the Upper Mojave Valley consist of severely deformed and highly metamorphosed gneiss and plutonic rocks which form the area's basement. Younger rocks record a warm continental shelf environment of a Late Paleozoic sea. These rocks include Carboniferous-age limestones and dolomites of the Oro Grande Group (McNeil, 1963) exposed in the unnamed mountain range containing Silver and Quartzite Mountains, east of George AFB. Exposures of these carbonates are visible in the central portion of the range, where they are mined for cement. The series also contains a significant quartzite component. The quartzite units are compositionally very mature, containing $95-99 \%$ quartz (Miller, 1977). The tremendous alteration of the sedimentary rocks throughout the region precludes a detailed interpretation.

Great masses of granite were intruded during the late Jurassic or early Cretaceous, and folded and faulted the overlying Oro Grande rocks. The accompanying uplift resulted in a high land mass. Hydrothermal solutions also contributed to the alteration of the sediments. Erosion subsequently removed the Paleozoic rocks, and those presently found in the region are remnants of the original deposits (McNeil, 1963).

The latite-andesite capping over the locally exposed granites provides limited evidence of Mesozoic volcanic flows. While these flows are believed to have extensively impacted the region, much of the local evidence has been eroded. In the range east of 
GAFB, remnants of the volcanics are contained in a unit that includes dark green, structureless, dacite-quartz latite (Miller, 1977). Also present are lenses of pebble conglomerate containing clasts of limestone, metasedimentary (meta-quartzites, marble, chert, and minor thinly layered calc-silicate), plutonic (monzonitic to granitic), and volcanic rocks.

Quaternary Deposits Quaternary alluvium forms the most widespread deposits of the Victor Valley and generally consists of valley fill with secondary fluvial, floodplain, and playa deposits. The majority of the sediments in the Victor Valley have been attributed to the Victorville Fan (Dibblee, 1960), an alluvial fan derived from the San Bernardino and San Gabriel Mountain ranges to the south.

Based on oil well logs southeast of GAFB (Dibblee, 1967), the thickness of the unconsolidated fill in the Victorville area is estimated to be greater than 700 feet, thinning eastward toward bedrock exposures. The deposits are buff to gray and are composed of a heterogeneous mixture of boulders, gravel, and sand of predominantly granitic composition. Exposures iocally contain fine-grained units of silt and clay considered to be lacustrine in origin (Jefferson, 1986).

Floodplain deposits along the Mojave River are predominantly sand, silt, and some gravel. These deposits are largely derived from local sediment and, therefore, are mostly re-worked Pleistocene deposits. 
Pleistocene playa deposits in the area include the Burkhardt dry lake, just north of the Upper Narrows, and Rancho Verde dry lake, south of the Upper Narrows. Burkhardt Lake sediments are primarily gray limy clay, with local streaks of yellow-gray and "blue" clay. The clays contain minor amounts of sand, and gravel is rare. Locally, salts have been found on the lake floor. Sediments merge laterally into alluvial slopes, where the amount of sand increases and grain sizes coarsen (McNeil, 1963). Land reclamation has obscured Burkhardt dry lake, and flooding for recreational uses has completely covered the Rancho Verde lake bed (McNeil, 1963).

The soils throughout the majority of the upper Mojave River basin formed from the residual material of the weathered rock. They have been described by McNeil (1963) as Sierozems that lack the normal soil profile due to scant vegetation or organic material. The development of the azonal desert soils is primarily a process of geological weathering or deposition (McNeil, 1963). The soils are pale gray to light brown, and locally contain near-surface caliche zones. Such caliche zones have been observed at GAFB.

Playa soils are generally saline from close proximity to the water table and evaporated salts. Playa soils are composed of clay with some sand and silt (McNeil, 1963). 


\section{Hydrogeology}

The study area occupies the Mojave River groundwater basin, which underlies approximately 4,000 square miles in the Mojave Desert. The basin originates in the San Bernardino Mountains and terminates northeast of Afton approximately 85 miles northeast of GAFB (Fig. 2). The lateral boundaries of the basin are mountains separating the Mojave River drainage basin from adjacent watersheds; however, the southeastern portion of the groundwater basin encompasses adjacent areas beyond the watershed boundaries (BookmanEdmonston Engineering, 1994).

The Mojave River groundwater basin is subdivided into smaller subareas generally separated by hydrogeologic boundaries and faults. The Victor Valley, including GAFB, occupies the Upper Mojave River Groundwater Basin which originates in the San Bernardino Mountains from a drainage area of just over 200 square miles (Bookman-Edmonston Engineering, 1994) above the Forksite Dam (also called the Mojave River Dam). The eastern and western boundaries of the upper Mojave River basin are basement rocks exposed in local bedrock highs and mountain ranges. The northem boundary is the Helendale fault, an active northwest-trending fault related to the San Andreas fault system.

The basement rocks within the upper Mojave River basin are essentially non-waterbearing. Locally perched aquifers, including the one beneath GAFB, do not produce economic quantities of water. Groundwater flow directions are predominantly northward to northeastward (Boyle Engineering Corp., 1987). 
Most of the region's water production wells draw from the Mojave River alluvial aquifer, which consists of approximately 60 to 100 feet of young, highly permeable river deposits above approximately 90 feet of older river deposits (Boyle Engineering Corp., 1987) The river deposits typically occupy an area approximately 2 miles wide except where bedrock crops out at the Upper and Lower Narrows near Victorville, where the channel narrows and deposits do not accumulate. The Mojave River alluvial aquifer yields significant quantities of water to local production wells.

The Mojave River alluvial aquifer is recharged intermittently along its entire length as a result of flooding in the Mojave River. Recharge is greatest in the San Bernardino and San Gabriel mountains, which receive higher amounts of precipitation than the desert. Data cullected by the USGS indicate that recharge water to the Mojave River is isotopically heavy and much of it originated as precipitation from air masses moving through Cajon Pass. Based on tritium data (Izbicki et al., 1994), water in the alluvial aquifer downstream of the mountain front was recharged after 1952 by water from the Mojave River.

Water levels in wells screened in the Mojave River aquifer are first encountered about 50 to 60 feet bgs (Montgomery Watson, 1995). During the summer, when surface flow in the river is absent, water levels in the alluvial aquifer decline as a result of evapotranspiration and groundwater pumping. Water level declines are greatest during drought periods in areas where the river has not flowed for several years. 
The area's regional aquifer occupies older unconsolidated alluvium and fan deposits that underlie the Victor Valley. According to the Lzbicki et al. (1994), the regional aquifer is more than 980 feet thick and contains most of the area's groundwater in storage. Groundwater recharge from rainfall is negligible due to the low precipitation rates and high evapotranspiration rates characteristic of the Mojave Desert.

Water in the regional aquifer adjacent to the Mojave River channel does not contain detectable tritium $\left({ }^{3} \mathrm{H}\right)$, and carbon $14\left({ }^{14} \mathrm{C}\right)$ data indicate that this water was recharged less than 2,400 years ago (Lzbiki et al., 1994). Recharge in this part of the regional aquifer is likely episodic, occurring primarily in wetter-than-average years.

During the early 1930's, when local groundwater levels are first known to have been recorded, depths to the regional aquifer throughout the Victor Valley area were approximately 120 feet bgs (Hardt, 1971), corresponding to elevations of approximately 2,750 to 2,700 feet msl in the GAFB area. While a slight water level decline ensued, regional groundwater elevations in the area remained close to 2,700-2,750 feet msl until at least the early 1980 's (Boyle Engineering, 1987). The most extreme water level declines occurred in the vicinities of Adelanto, Victorville, and southwest of GAFB, where the city of Adelanto has a production well field. The USGS recently informed Montgomery Watson that groundwater elevations recorded in those production wells were approximately 2,585 feet msl, reflecting a drop of approximately 165 feet in regional water elevations between the early 1980's and the present (P. Martin, oral communication, 1996). 


\section{BACKGROUND OF GEORGE AIR FORCE BASE}

George Air Force Base was initially activated on October 1, 1941, and was used for flight training during World War II and again following the outbreak of the Korean War (Montgomery Watson, 1995). In December 1988 the Defense Secretary's Commission on Base Realignments and Closures (BRAC) recommended the closure of 145 military installations, including GAFB. In February 1990 GAFB was placed on the National Priorities List by the U.S. Environmental Protection Agency (EPA) as a result of the identification of confirmed and suspected contamination of the soil and groundwater. GAFB was formally closed in December 1992 and is being turned over to the local community for a variety of reuse activities (Montgomery Watson, 1995).

Since 1982, numerous environmental investigations have been conducted at GAFB under the United States Air Force's Installation Restoration Program (IRP), resulting in the identification of a number of individual sites that have been impacted by hazardous materials. To date, most of these sites were recommended for no further action following additional investigations which proved that they presented no risk to human health or the environment.

The sites remaining on the regulatory lists for remediation are grouped into three operable units (OUs) according to their locations and the nature of their contaminants. 
The individual OUs at GAFB are displayed on Figure 5. A brief description of the three individual OUs is presented below.

\section{Operable Unit 1}

OU 1 consists of a plume of TCE dissolved in groundwater beneath approximately 600 acres in the northeast portion of the base and off-base to the north (Fig. 6). Because the TCE plume contains concentrations above the federal Maximum Contaminant Level (MCL) of 5 micrograms per liter $(\mu \mathrm{g} / \mathrm{L})$, the Air Force has implemented an active groundwater remediation program at the request of the regulatory community. The OU 1 plume is being remediated using groundwater extraction and treatment by air stripping.

Approximately 80 percent of the estimated TCE mass exists in a perched aquifer encountered beneath the base. An estimated 20 percent of the plume mass resides in the deeper regional aquifer. Small amounts of contaminated water from the plume's leading edge in the regional aquifer are believed to have impacted the Mojave River alluvial aquifer northeast of GAFB (Montgomery Watson, 1995).

The primary source of the OU 1 TCE plume is suspected to be contaminated waste water from the former industrial/storm drain that infiltrated through the unlined arroyo near the north base boundary. A secondary source is believed to be a former fire training area (FT-19) in the northeastern portion of the base (Fig. 5). 


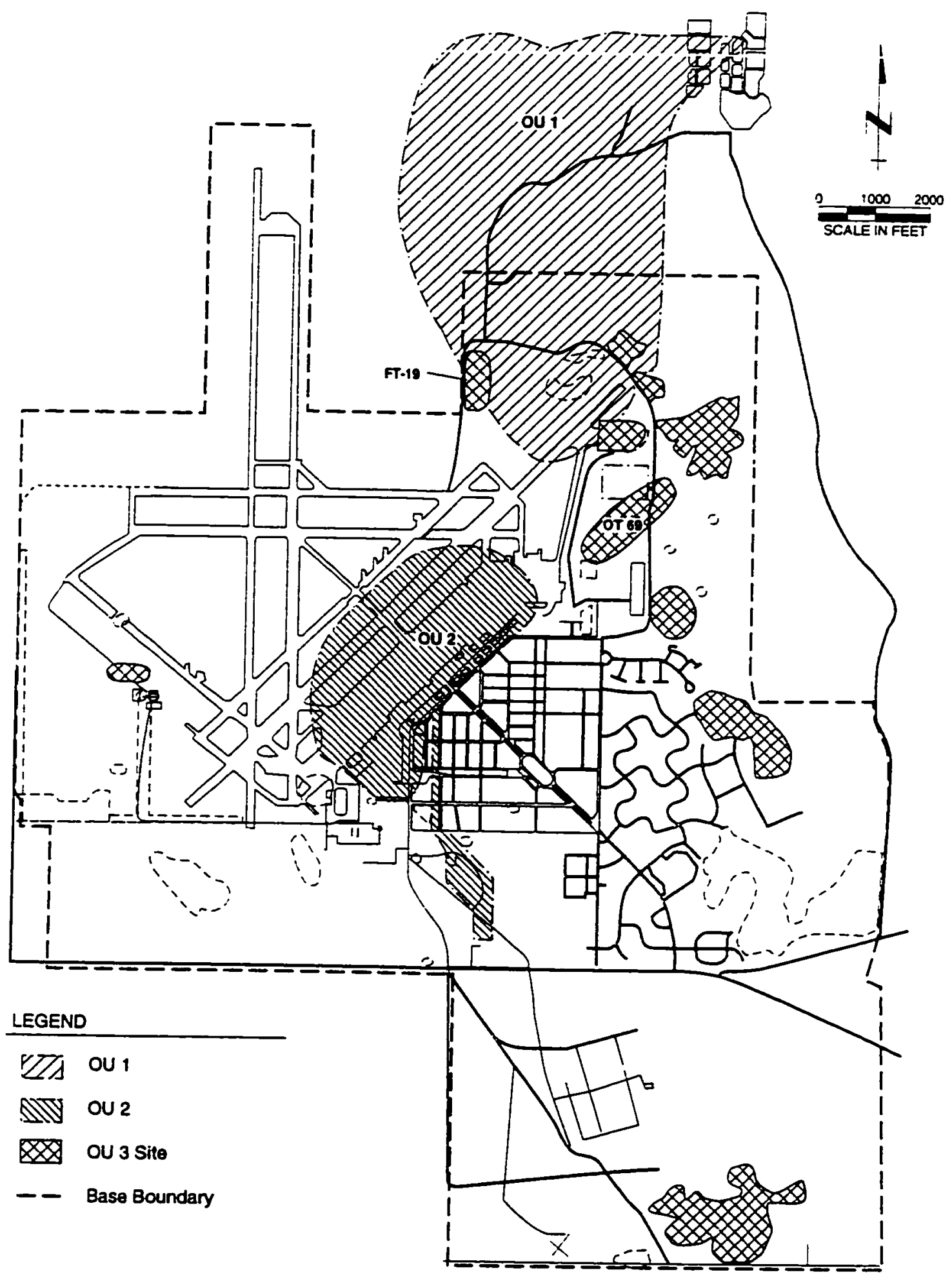

Figure 5. George Air Force Base Operable Unit site Locations (from Montgomery Watson, 1995). 


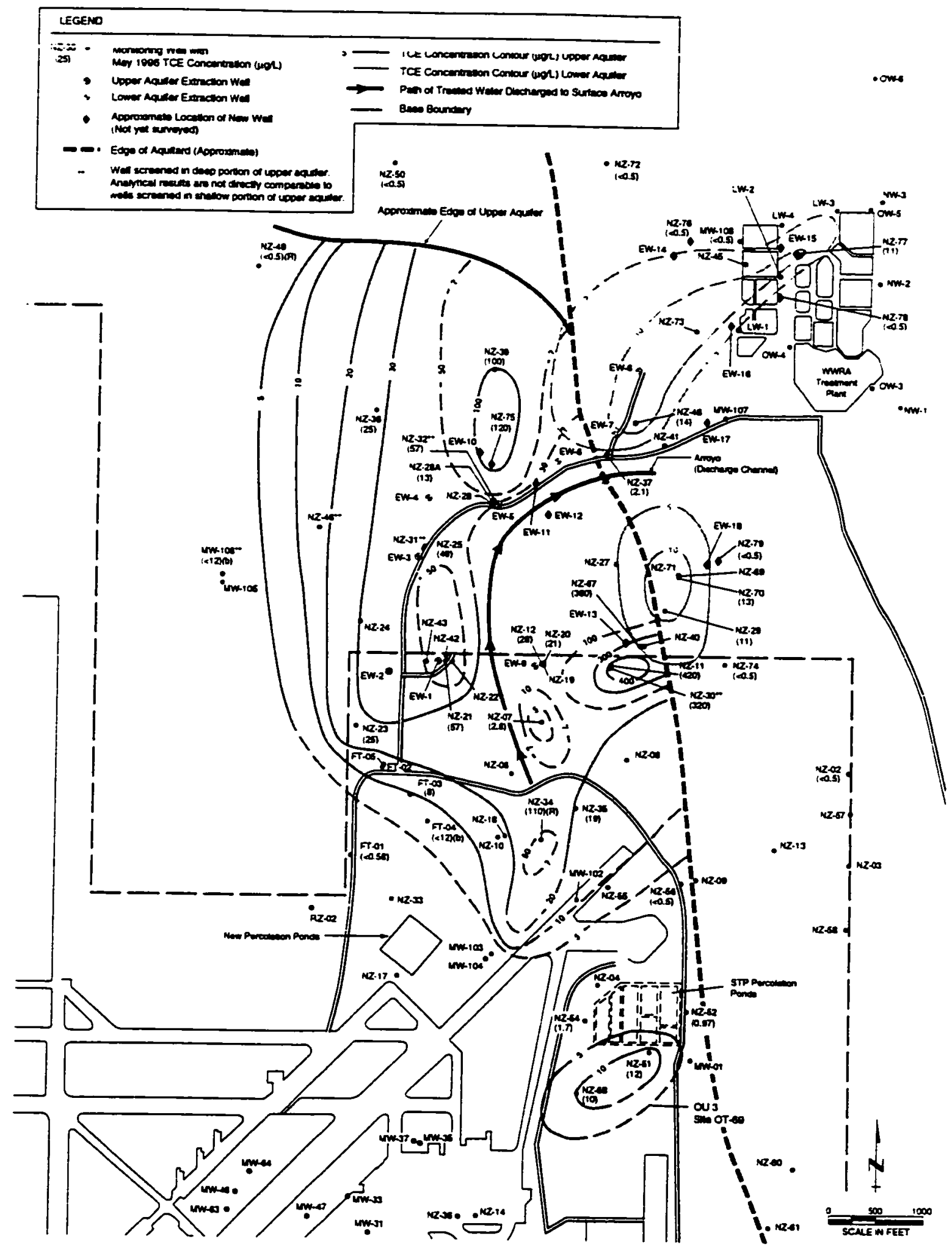

Figure 6. Map of the OU 1 TCE plume (from Montgomery Watson, 1996b). 
Operable Unit 2

OU 2 consists of a plume of jet propulsion fuel grade $4(J P-4)$ beneath the flightline in the central portion of the base. The plume, which includes free-phase liquid, impacts only the perched aquifer. A small, localized TCE plume has also been identified in the southern portion of OU 2 and contains TCE concentrations up to approximately 12 $\mu \mathrm{g} / \mathrm{L}$. The JP-4 plume is being remediated through free-phase fuel recovery and natural attenuation. The OU 2 TCE plume is also being allowed to naturally attenuate considering its relatively low concentrations and limited extent.

\section{Operable Unit 3}

OU 3 consists of 60 miscellaneous sites. The results of extensive soil and groundwater investigations and risk assessments narrowed the list of sites presenting potential human and environmental risk to eight. Five of these sites are landfills containing scattered areas of low-level contamination, in all cases limited to shallow soil (typically less than 20 feet). These sites are being remediated by constructing native soil covers or rehabilitating existing soil covers (Montgomery Watson, 1996a). Only three of the OU 3 sites, FT-19, OT-51, and OT-69 (Fig. 5), contain groundwater contamination that impacts limited areas of the perched aquifer only. These sites are being remediated via natural attenuation or using bioventing and soil vapor extraction. 


\section{EXISTING CONCEPTUAL HYDROGEOLOGIC MODEL}

The existing conceptual hydrogeologic model for GAFB (Montgomery Watson, 1995) essentially states that the geology beneath GAFB consists of a crystalline basement at a depth of approximately 750 to 1,000 feet. That basement is overlain by three stratigraphic units composed primarily of alluvial fan material originating in the surrounding mountains. Figure 7 presents a simplified depiction of the hydrogeologic model. Figures 8 and 9 are cross sections modified from the existing site model that display in more detail the lithology beneath GAFB.

\section{The Upper Alluvial Unit}

The shallowest sediments beneath GAFB, named the "Upper Alluvial Unit" by Montgomery Watson (Montgomery Watson, 1995), were assigned to the Victorville Fan, which is composed predominantly of granitic sediment originating in the San Gabriel and San Bernardino Mountains approximately 15 miles south of the base (Fig. 1).

The Upper Alluvial Unit consists of sediments from the ground surface to approximately 150 feet bgs. The sediments are a heterogeneous mixture of fine- to medium-grained sand, with local caliche zones, gravel, and cobbles. The sand typically is brown to yellow- or red-brown and sub-angular to angular. Sand ranges from well-sorted to poorly-sorted, and contains interbedded clay and silt units, which are lenticular and of limited extent (Montgomery Watson, 1995). Fine-grained units range in thickness from 


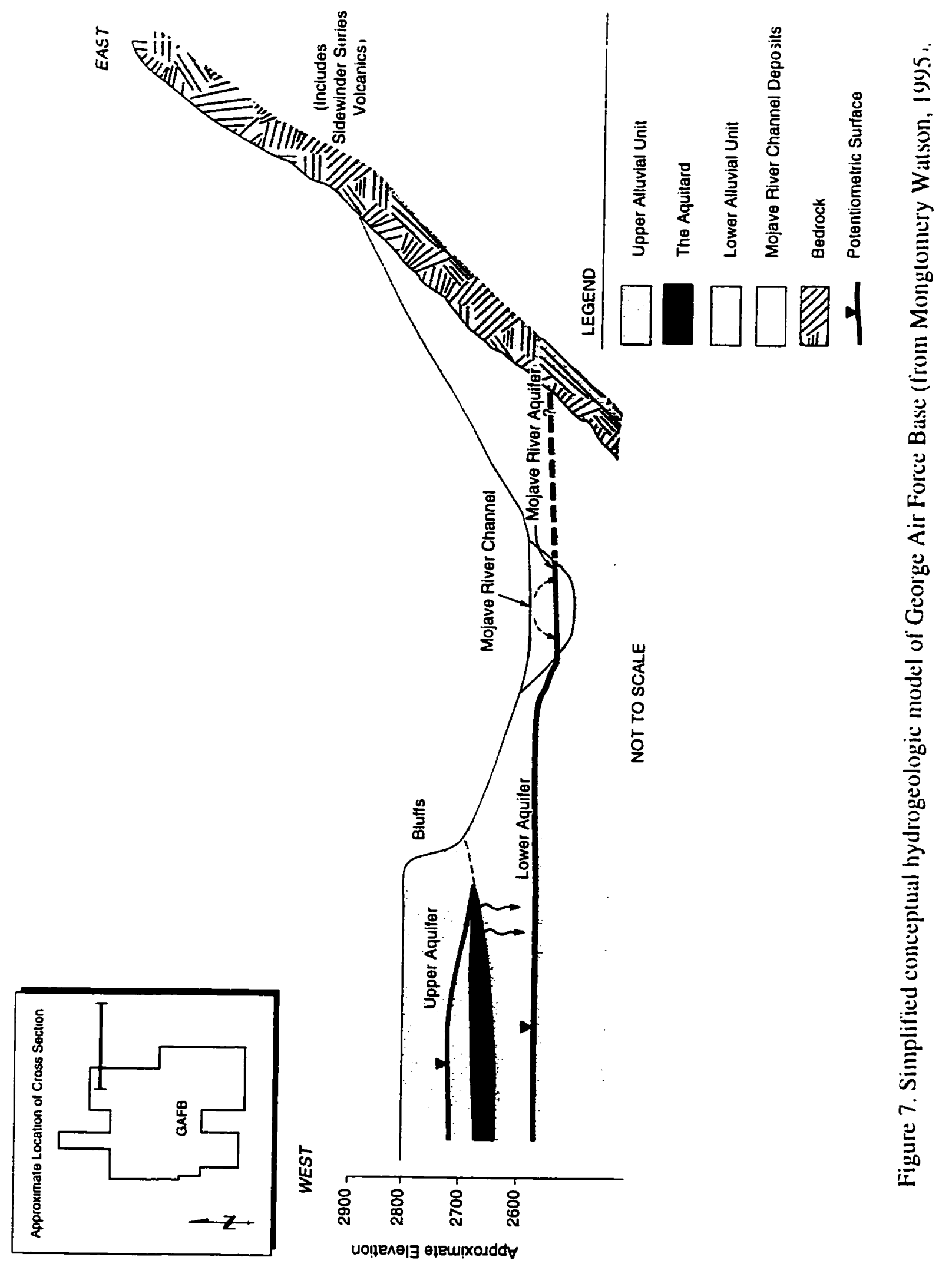



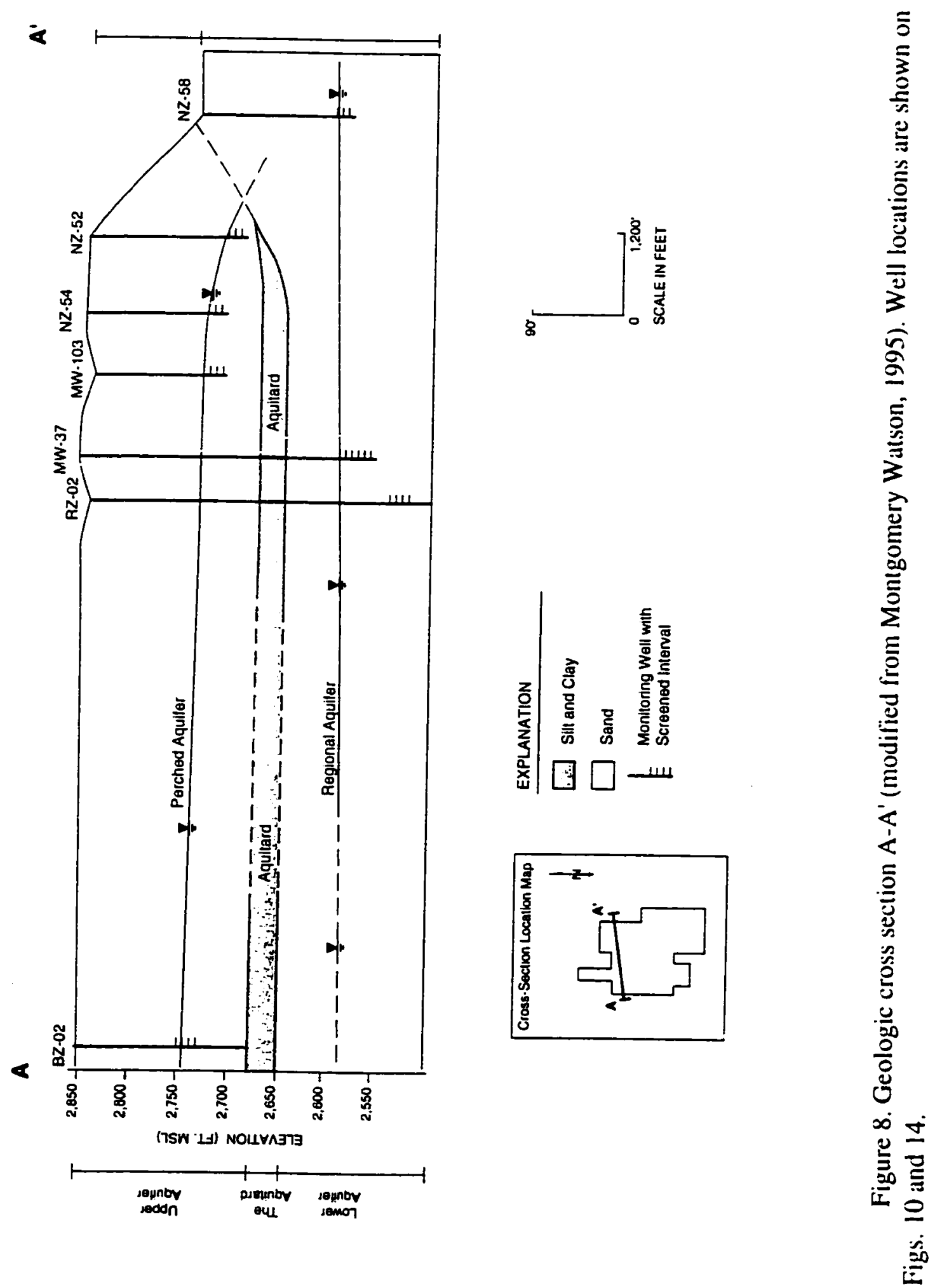

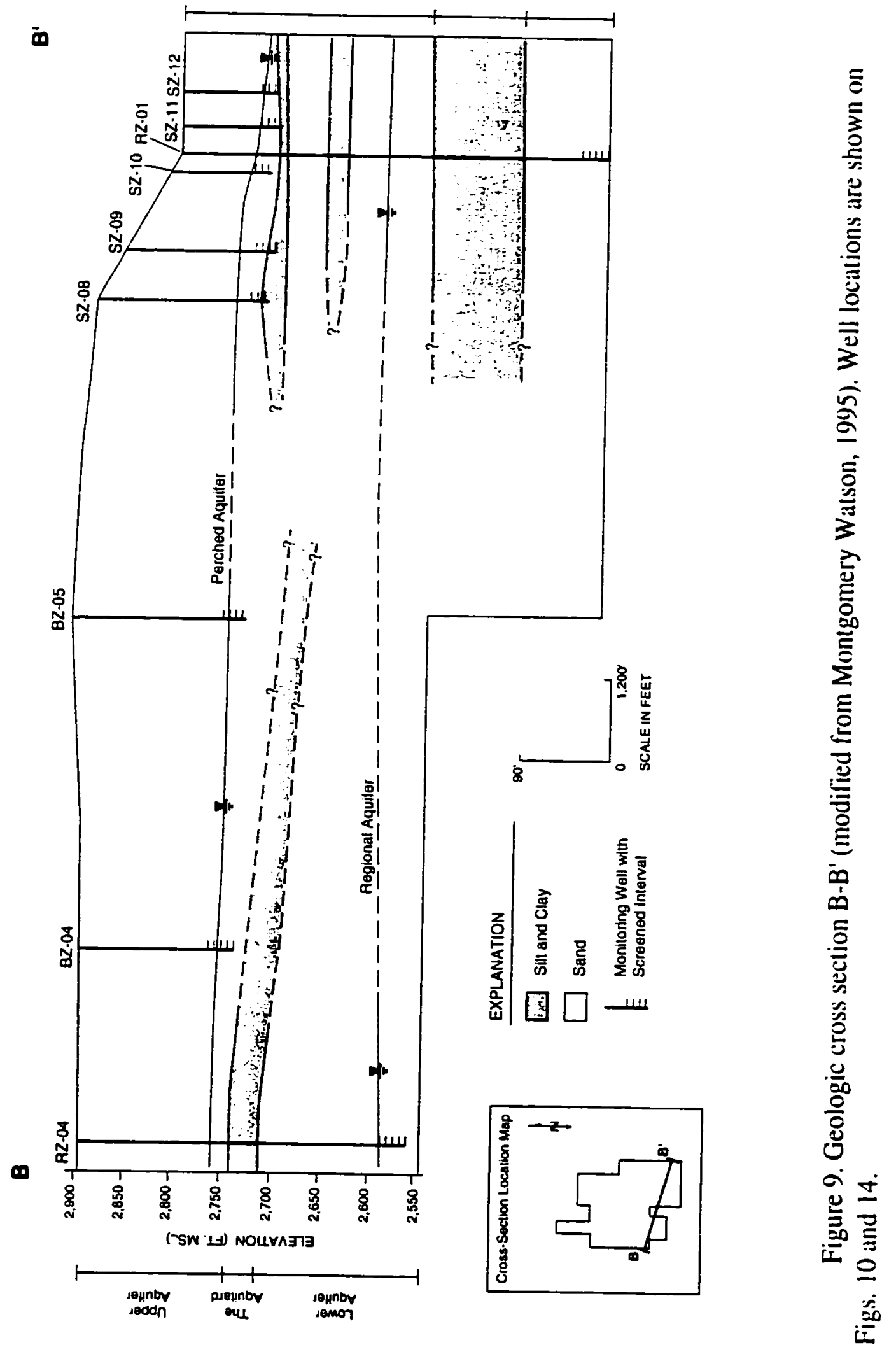
only a few feet to over 20 feet (Montgomery Watson, 1995). The Upper Alluvial Unit may also contain local stream-channel deposits of the paleo-Mojave River, which presently flows east of GAFB.

\section{The Perched Aquifer}

The deeper portions of the Upper Alluvial Unit are occupied by a perched aquifer of limited lateral extent. Figure 10 displays the surface elevations and extent of the perched aquifer beneath GAFB. This figure is based on water level data collected by Montgomery Watson during May 1996, which was the last basewide water level survey conducted at GAFB (Montgomery Watson, 1996b). The extent of the perched aquifer beneath GAFB generally corresponds to the extent of the underlying aquitard; however, in some locations the perched aquifer appears to disappear before reaching the aquitard's edge (Montgomery Watson, 1995). Based on water levels and lithologic logs, the perched aquifer pinches out north of GAFB and along the eastern boundary of the base. The extent of the perched aquifer off-base to the south and west is not known (Montgomery Watson, 1995).

\section{The Aquitard}

The Upper Alluvial Unit is underlain by a clay and silt aquitard that exists beneath most of the base, pinching out along the eastern base boundary and to the northeast. The 


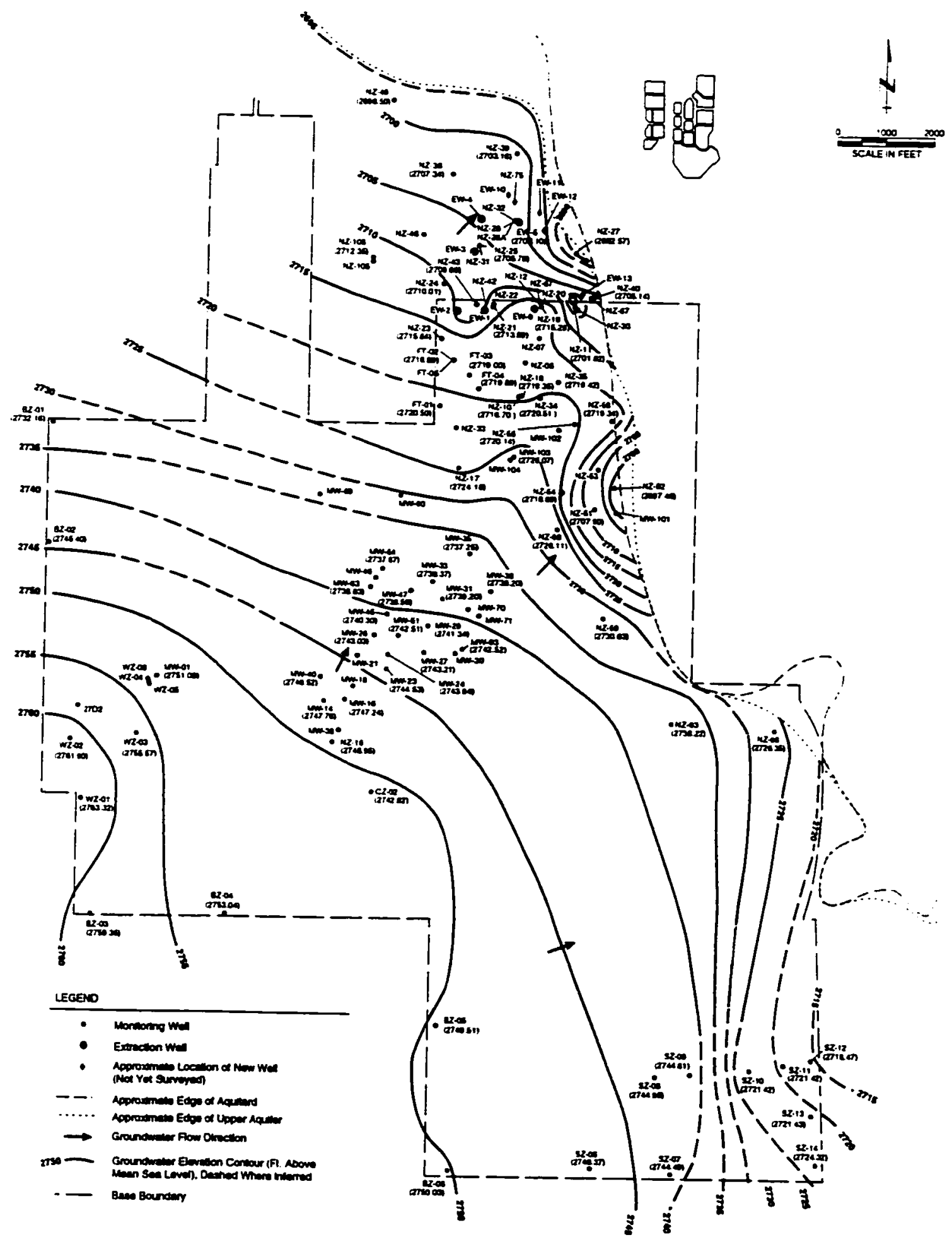

Figure 10. Groundwater elevations in the perched aquifer, May 1996 (from Montgomery Watson, 1996b). 
aquitard is believed to be a lacustrine deposit formed in a basin occlipying the vicinity of GAFB during the Pleistocene. The aquitard is hydrogeologically significant as it supports the perched aquifer beneath GAFB. Figures 11 and 12 display the aquitard's surface and thickness, respectively, according to the existing site model (Montgomery Watson, 1995). The approximate eastern edge of the aquitard was inferred based on the pattern of outcrops east of GAFB, evidence from borehole logs, and the disappearance of the perched aquifer (Montgomery Watson, 1995). Indirect evidence such as trees and springs, which are believed to be supported by or caused by seepage of water perched above a fine-grained unit, were also used to identify the edge of the unit. Fine-grained units cropping out in exposures in the southern portion of the base and southeast of the base are believed to be the aquitard (Montgomery Watson, 1995). Further north, there are no outcrops of the aquitard, and its edge is believed to be west of the Mojave River bluffs, buried beneath Upper Alluvial Unit sediment (Montgomery Watson, 1995).

The uppermost portion of the aquitard is composed of gray to olive-brown silt to very fine-grained, micaceous sand. The silt and sand are typically thinly laminated (Fig. 13a), a characteristic that is interpreted to indicate calm water deposition. The lower portion of the aquitard typically is highly plastic, massive, brown clay containing local white caliche nodules and very little sand (Fig. 13b). The clay typically lacks structure such as cusps or fissures that would indicate drying. The olive-brown color likely reflects deposition in an anoxic, consistently hydrated setting typical of a lacustrine environment. 


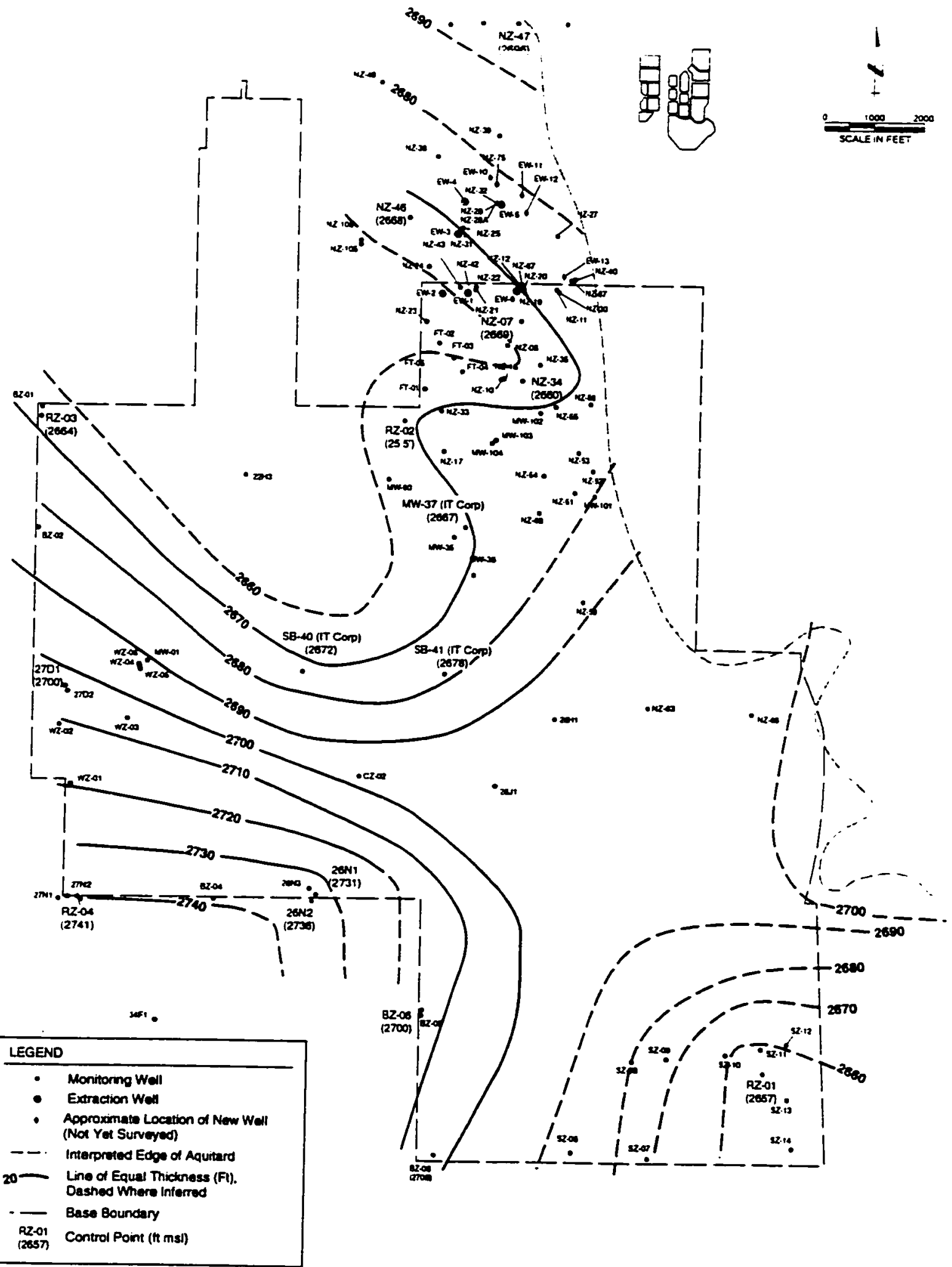

Figure 11. Map of the aquitard surface (from Montgomery Watson, 1996b). 


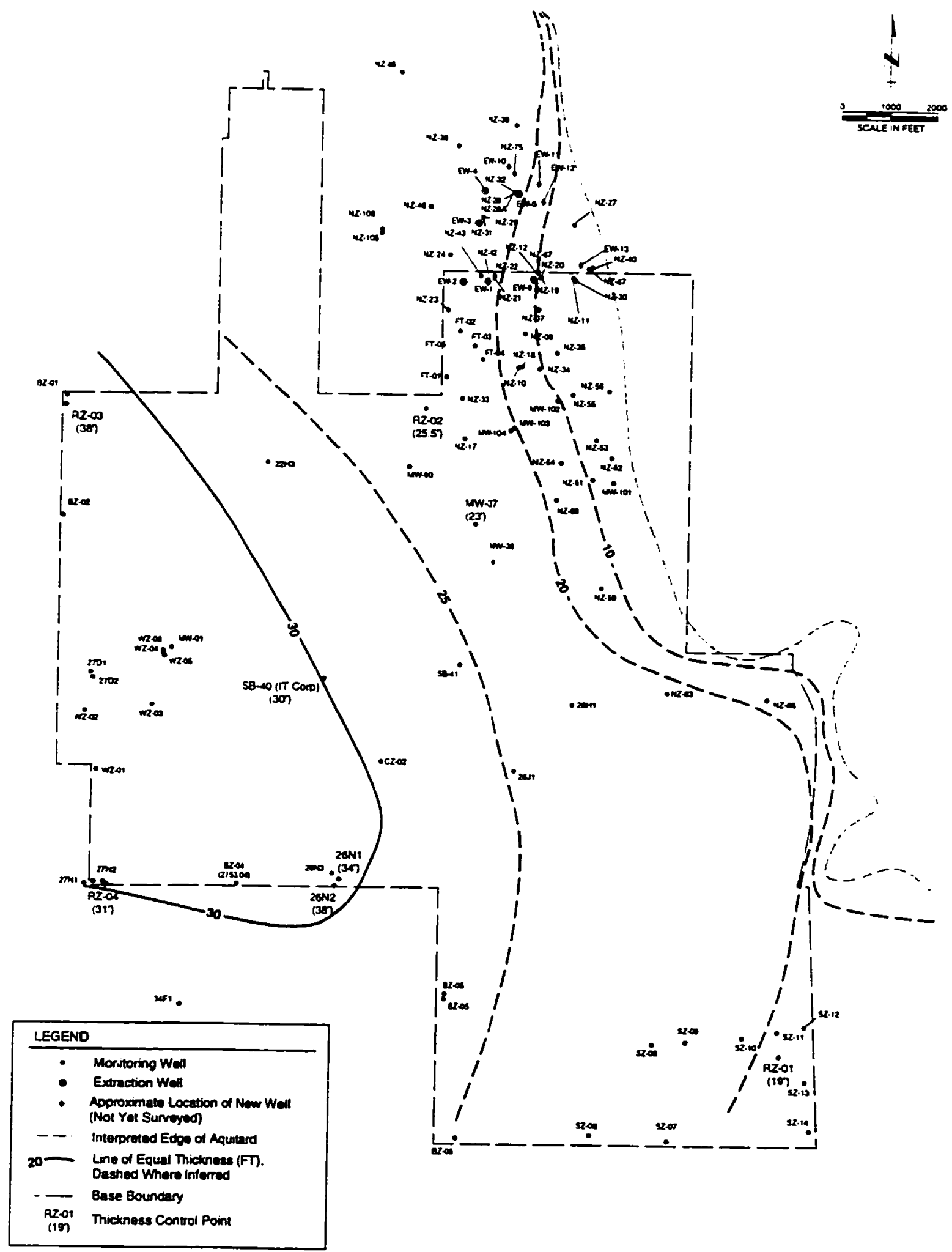

Figure 12. Aquitard thickness (from Montgomery Watson, 1995). 


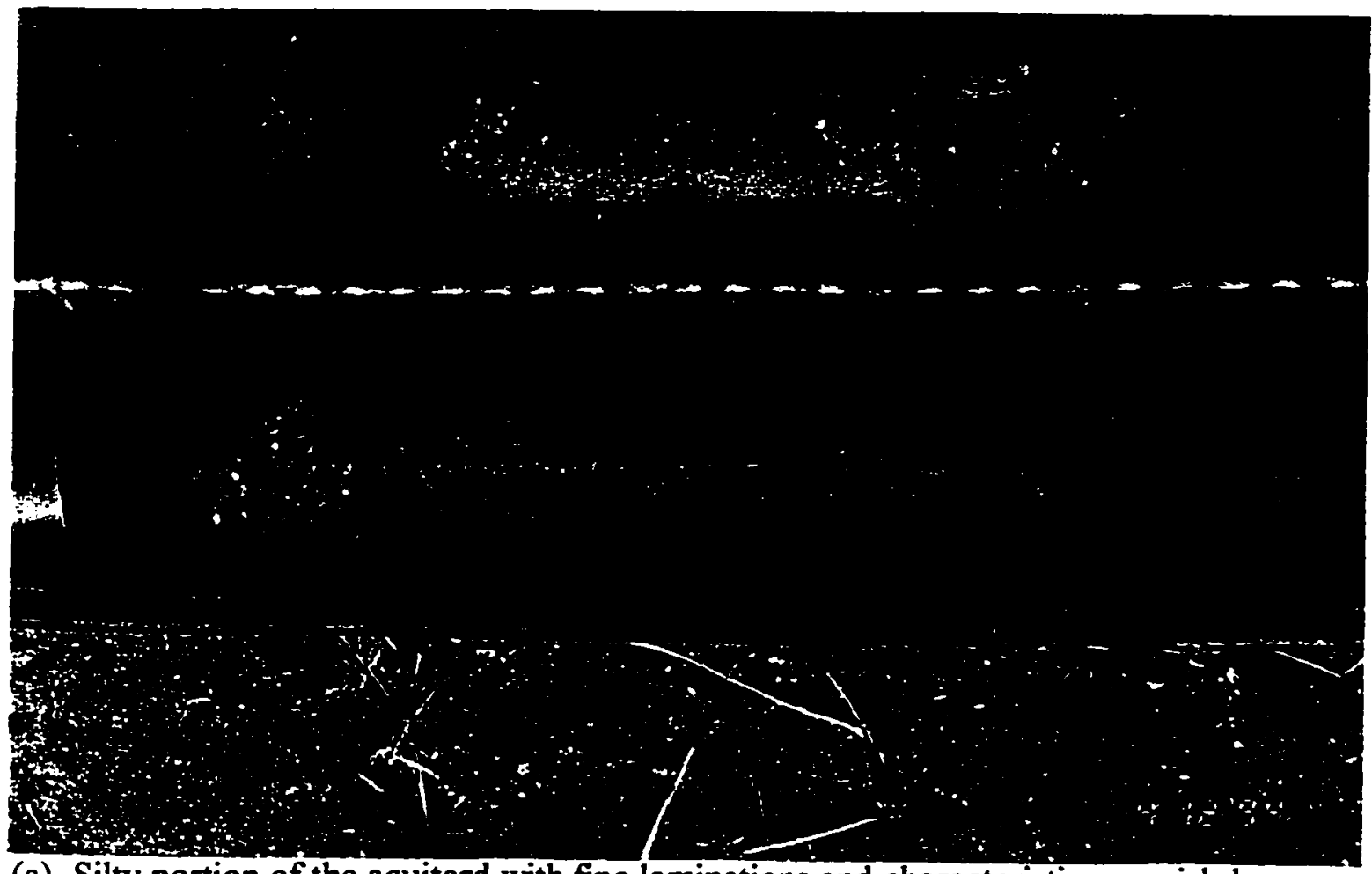

(a) Silty portion of the aquitard with fine laminations and characteristic greenish-brown color. Sample from RZ-03 (Fig. 11) at 195 feet.

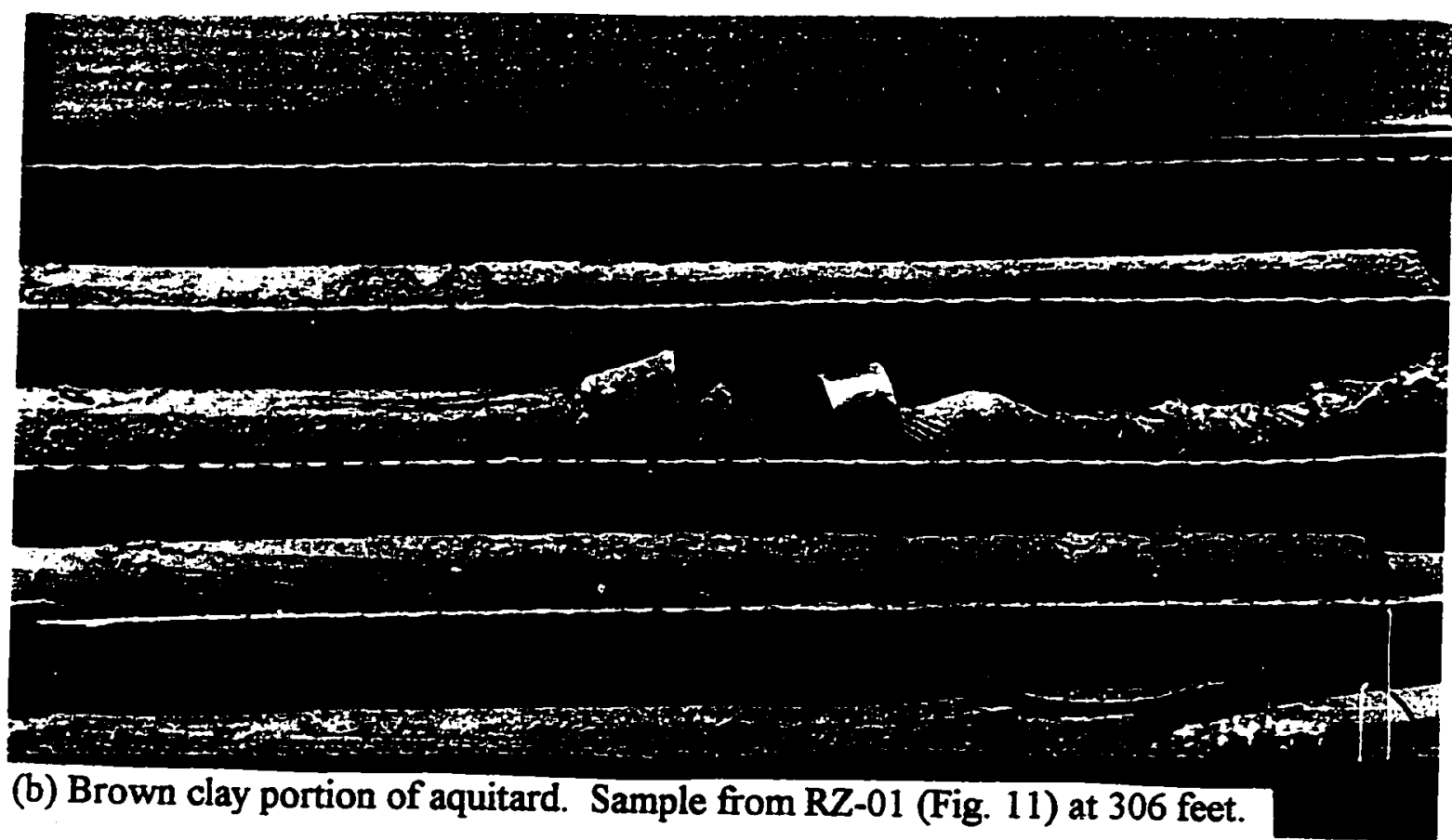

Figure 13. Silt (a) and clay (b) portions of the aquitard. 
Vertical hydraulic conductivities of aquitard silt and clay range from $9.1 \times 10^{-9} \mathrm{~cm} / \mathrm{sec}$ to $5.0 \times 10^{-8} \mathrm{~cm} / \mathrm{sec}$ (Montgomery Watson, 1995).

The top of the aquitard is encountered beneath most of the base between about 130 feet and 200 feet bgs, corresponding to elevations between approximately 2,740 feet $\mathrm{msl}$ and 2,660 feet msl. The average thickness of the aquitard basewide is about 25 feet. The aquitard is thickest in the western portion of the base, where it was measured to be 38.5 feet thick. Because of its relatively uniform thickness, the aquitard does not appear to have been significantly eroded before it was buried, and variations in surface topographic expression are interpreted to reflect the surface upon which the unit was deposited. The unit gradually thins eastward and northward before it pinches out. The unit is exposed in outcrop southeast of the base. The existing conceptual site model does not address the regional extent of the aquitard north, south, and west of GAFB and the OU 1 TCE plume.

\section{The Lower Alluvial Unit}

The sediment stratigraphically below the aquitard is called the Lower Alluvial Unit (Montgomery Watson, 1995). These soils contain a heterogeneous mixture of interbedded sand with varying amounts of gravel, silt, and clay. The sand is brown to redbrown, poorly sorted, fine- to medium-grained, sub-angular to angular, and is predominantly granitic. The sand of the Lower Alluvial Unit generally resembles the 
Upper Alluvial Unit, but there are several compositional differences that distinguish the two, most notably the presence of a volcanic component in the Lower Alluvial Unit.

The source of the volcanics in the Lower Alluvial Unit is believed to be the small unnamed mountain range east of GAFB. The central and northern portions of this range are mapped as a porphyritic complex of primarily andesite and latite, thought to be of Mesozoic age (Dibblee, 1967).

\section{The Regional Aquifer}

The upper 40 to 60 feet of the Lower Alluvial Unit are unsaturated, but below this depth the Lower Alluvial contains groundwater of the area's regional aquifer system. The regional aquifer is encountered at approximately 210 to 250 feet bgs basewide. Elevations in the regional aquifer range from 2,588 to 2,582 feet msl, dropping approximately 6 feet basewide. Figure 14 displays the potentiometric surface and the extent of the regional aquifer beneath GAFB. This figure is based on water levels collected during May 1996, which was the last nearly basewide water level survey conducted at GAFB (Montgomery Watson, 1996b). The Lower Alluvial Unit is believed to extend to the bedrock surface beneath GAFB, however, it is not known if the regional aquifer corresponds to this thickness. 


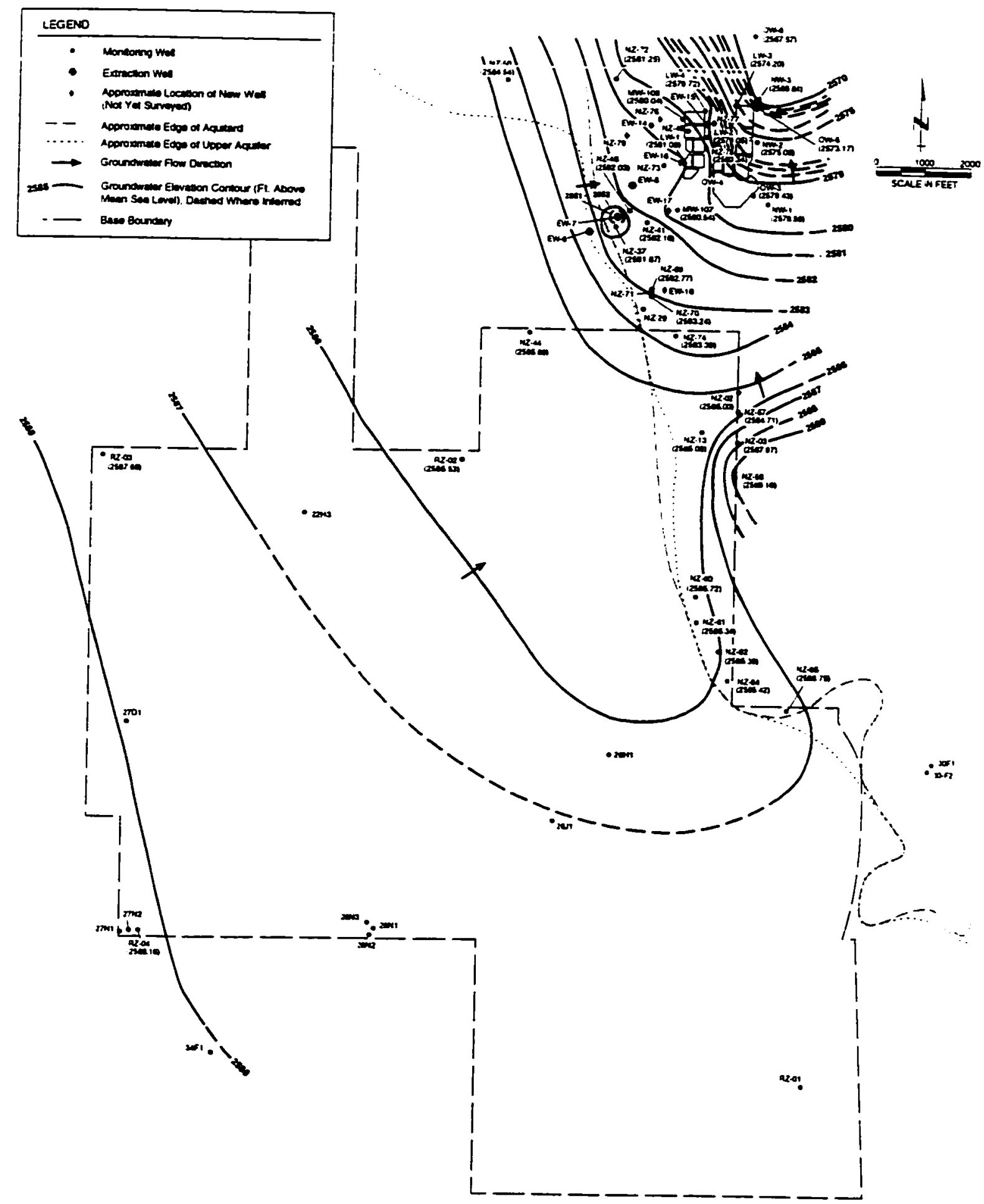

Figure 14. Groundwater elevations in the regional aquifer, May 1966 (from Montgomery Watson, 1996b). The groundwater elevation for RZ-01 is not included in the figure because aquifer conditions in this vicinity are confined as opposed to elsewhere on base. 


\section{OBJECTIVES OF THIS STUDY}

The primary objective of this thesis is to assess the existing conceptual hydrogeologic model for GAFB in order to develop a consistent model for the site and the surrounding vicinity by integrating available geologic, chemical, and hydrogeologic data. Secondary objectives are to seek: 1) any qualitative and/or quantitative evidence within lithological and chemical data that indicate the provenance of the Upper and Lower Alluvial Units; 2) evidence indicating the depositional environment of the aquitard and the nature of its distribution basewide; and 3) any quantifiable differences in the hydrogeologic characteristics and groundwater quality between the two aquifers beneath GAFB. 


\section{METHODS}

The data review, fieldwork, and laboratory studies for this project were conducted between 1994 and 1996.

\section{Review of Existing Data}

The data reviewed to support the investigations performed for this thesis include published and unpublished data from regional groundwater studies and governmentfunded investigations at GAFB, lithologic and geophysical logs, soil cores, aquifer pumping test results, results of chemical and geotechnical laboratory analyses for soil and groundwater samples, and groundwater levels collected at GAFB.

Lithologic data reviewed included well drillers' logs from the surrounding region. These logs were dated from the late 1950's through the late 1980's, and included several wells drilled by Boyle Engineering for an investigation into alternative water supplies for George AFB (Boyle Engineering Corp., 1987).

Approximately 50 borehole logs compiled by various consultants making environmental investigations at George AFB were reviewed. Also examined were soil cores from boreholes RZ-01 through RZ-04 installed by Montgomery Watson in 1994. The locations of boreholes RZ-01 through RZ-04 are presented on Figure 15. RZ-01 through RZ-04 were installed by Montgomery Watson primarily to examine the location 


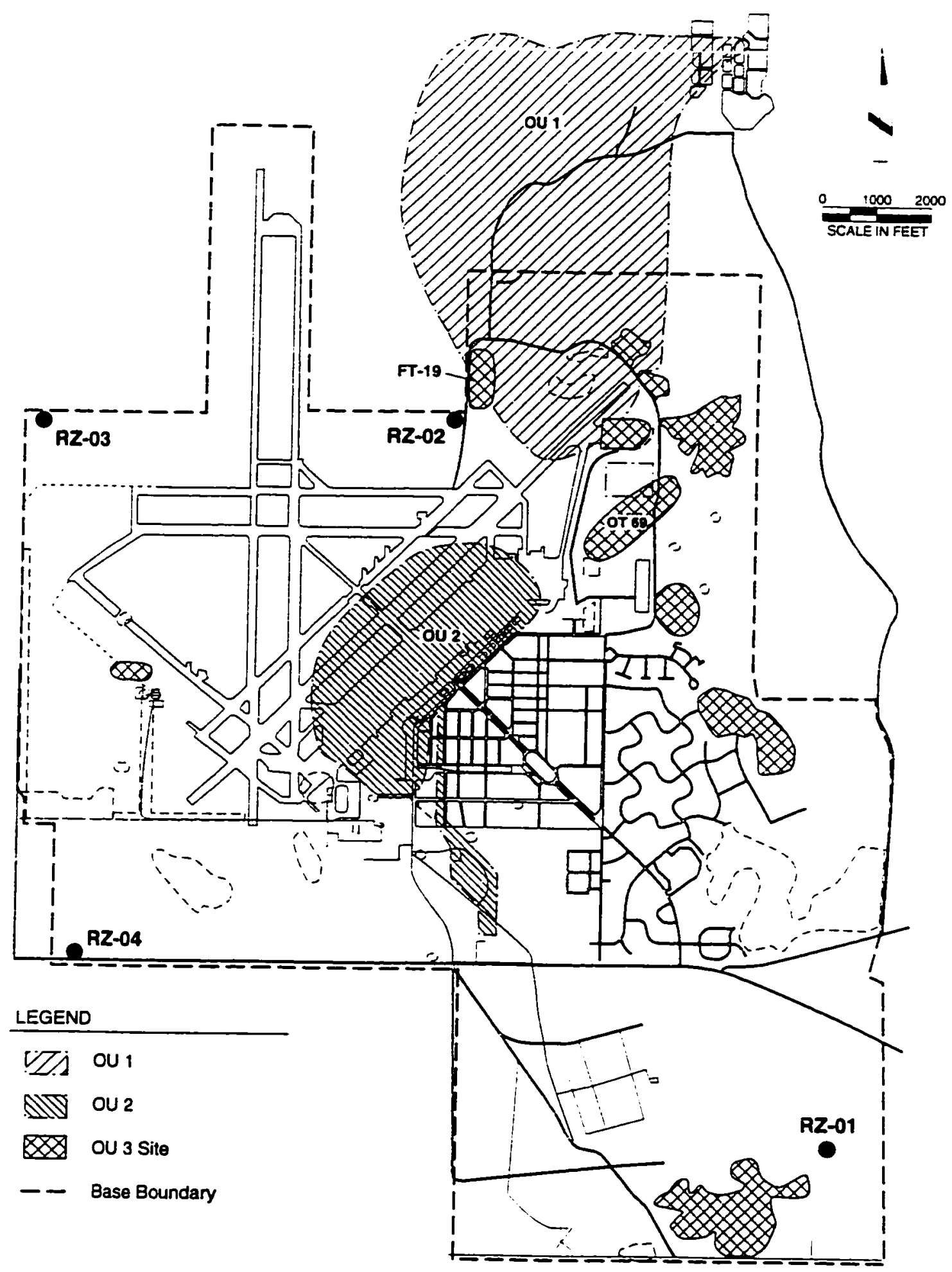

Figure 15. Locations of "RZ" boreholes (basemap from Montgomery Watson, 1995). 
and extent of the aquitard beneath GAFB (Montgomery Watson, 1995). These boreholes were completed as regional aquifer wells. The primary objective of reviewing lithologic borehole logs was to obtain additional information regarding the extent and characteristics of the aquitard, and to investigate the presence of volcanics or other distinguishing soil characteristics.

Geotechnical information for samples collected from the saturated sand portions of the perched and regional aquifer was examined to establish potential trends and identify distinguishing characteristics between the two aquifers. Geotechnical information was tabulated and coefficients of uniformity $\left(\mathrm{C}_{\mathrm{u}}\right)$ were calculated using grain size distribution curves. This information was compared to vertical hydraulic conductivities obtained from falling head permeameter tests (Montgomery Watson, 1995). The geotechnical characteristics were examined to evaluate whether certain characteristics generally applied to distal versus proximal source deposits.

The results of historical and recent aquifer testing were tabulated. Figures displaying the distribution of hydraulic conductivity in the perched and regional aquifers were created. using information from pumping tests.

Background concentrations of metals and selected constituents in groundwater were also tabulated and graphs were created for general comparison. Analytical results for major ions and anions were used to draw Stiff and Piper diagrams. 


\section{Field Work}

The author performed field mapping visits to the GAFB area in March and June 1994, and in the summer through fall of 1996. Mapping notes were recorded in field logbooks and directly on a USGS 7.5-minute map of the Victorville and Adelanto quadrangles. Some field mapping was performed with USGS personnel to exchange information regarding observations and insights on the area.

The primary objectives of field mapping were to become familiarized with the visual differences between the primary lithologic units beneath GAFB, to identify exposed contacts between the units, to examine characteristics of the Victorville Fan, and to attempt to locate potential outcrops of the aquitard to better understand its extent.

\section{$\underline{X-R a y ~ D i f f r a c t o m e t r i c ~ T e s t i n g ~}$}

$X$-Ray diffractometric (XRD) testing was performed on five samples to gather qualitative information regarding the mineral composition of the aquitard and to provide a basis for comparison of samples collected from around the base. The results of XRD testing were also examined to determine the presence of other important indicator minerals, such as evaporites or zeolites, that could provide clues to the aquitard's origin.

Samples tested using XRD are summarized in Table 1. These samples were selected from soil cores from boreholes for regional aquifer wells RZ-01 through RZ-04. 
These wells provide good basewide coverage and are among the deepest of the boreholes drilled for environmental investigations at GAFB. Continuous cores from the boreholes

Table 1. Summary of Samples Tested Using X-Ray Diffractometric Testing

\begin{tabular}{|c|c|c|c|}
\hline $\begin{array}{l}\text { Sample } \\
\text { Number }\end{array}$ & $\begin{array}{l}\text { Location and } \\
\text { Depth (bgs) }\end{array}$ & $\begin{array}{l}\text { Elevation } \\
\text { (feet msl) }\end{array}$ & Comments \\
\hline 1 & $\mathrm{RZ}-01$ at 157 feet & 2.655 & $\begin{array}{l}\text { Brown clayey silt: shallow unit in southeast: previously } \\
\text { identified as aquitard }\end{array}$ \\
\hline 2 & $\mathrm{RZ}-0 \mathrm{I}$ at 302 feet & 2.505 & Grayish-brown clay; offset aquitard in southeast \\
\hline 3 & $R Z-02$ at 195 feet & 2.647 & $\begin{array}{l}\text { Brown clay: near bottom of aquitard; northeast portion of } \\
\text { GAFB }\end{array}$ \\
\hline+ & $\mathrm{RZ}-03$ at 200 feet & 2.640 & $\begin{array}{l}\text { Brown clay: near bottom of aquitard: northwest portion } \\
\text { of GAFB }\end{array}$ \\
\hline 5 & $\mathrm{RZ}-04$ at 172 feet & 2.723 & $\begin{array}{l}\text { Olive clay/clayey silt: middle of aquitard: southwest } \\
\text { portion of GAFB }\end{array}$ \\
\hline
\end{tabular}

- Samples from each location were prepared as (1) air-dried samples mounted on greased glass slides, and (2) clay smears. After initial XRD testing, clay smears were XRD-tested after the following treatments: ( 1 ) heating at $60^{\circ} \mathrm{C}$ above an ethylene glycol pool; (2) heating to $400^{\circ} \mathrm{C}$; and (3) heating to $550^{\circ} \mathrm{C}$.

had been collected by Montgomery Watson and were stored in wax-coated cardboard boxes.

Most of the samples were selected from brown, clayey portions of the aquitard. Two samples from RZ-01 were taken from fine-grained units at different depths to see if one or the other would compare more closely with aquitard samples elsewhere. 


\section{Sample Preparation}

The selected air-dried samples were ground using a porcelain mortar and pestle. A portion of the powder from each sample was mounted on a greased glass slide. To avoid dissolving potential evaporites, these samples were not wetted before mounting.

The remaining portions of the powdered samples were shaken in distilled water to promote dispersion and separation of the sand-sized grains from the clay- and silt-sized grains. After allowing the samples to settle, a spatula was used to remove clay from the top portion, which contained predominantly fine-grained material. This material was smeared onto glass slides and allowed to air-dry. The air-dried samples were X-Rayed first, before further treatment.

\section{Glycolation and Heating}

According to instructions published by the University of Washington Oceanography Department (University of Washington, 1961), each air dried clay smear was placed in a desiccator above a pool of ethylene glycol and heated in an oven at $60^{\circ} \mathrm{C}$ for one hour. Exposure to the ethylene glycol vapor facilitates expansion of any montmorillonoid clays. The lattices of such minerals swell from about 12 angstroms $(\AA)$ $15 \AA$ to $17 \AA-18 \AA$, which distinguishes them from the non-expanding $14 \AA$ clays chlorite and "vermiculite" (University of Washington, 1961). After glycolation, the samples were tested using XRD. 
The glycolated samples were subsequently heated at $400^{\circ} \mathrm{C}$ for one hour to differentiate any chlorite and "vermiculite" clays. This temperature does not collapse chlorite, but breaks down the vermiclite clays to $10 \AA$ where they re-enforce the illite peak (University of Washington, 1961). The samples were then analyzed using XRD.

The samples were then heated to $550^{\circ} \mathrm{C}$ for one hour to collapse the strucsure of any kaolinite and to diminish or eliminate all but the $14 \AA$ basal reflection of chlorite. This final heating concentrates chlorite into one peak (14 $\AA$ ) with no other clays remaining to interfere with that peak (University of Washington, 1961). This heating was again followed by XRD testing.

\section{Testing Parameters}

All of the sample mounts were scanned from 2 to 36 degrees two theta on a Philips Electrical Instruments diffractometer using copper radiation and nickel filter at 35 kilovolts (kV) and 15 milli-amps (mA). The machine was set for 200 steps per degree.

Data Presentation and Interpretation

The output from XRD testing was read using computer software specially written for the Philips Electrical Instruments diffractometer. Results were stored on a diskette and subsequently were downloaded into Microsoft ${ }^{\circ}$ EXCEL spreadsheets. Results were 
translated by the author from two theta into d-spacing in angstroms $(\AA)$ using the following conversion formula included in the software package:

$$
\mathrm{d} \text {-spacing }=1.15418 / 2\{\sin [(2 \text { theta/2) } \times(\Pi / 180)]\}
$$

where I. 15418 equals the copper radiation wavelength of the diffactometer.

Graphs of converted results were created using EXCEL's graphing program. For each sample test, $d$-spacing was plotted on the $x$-axis against relative intensity on the $y$ axis.

The outputs for the air-dried, crushed samples were examined for potential evaporites or zeolites that would have been dissolved or destroyed by wetting performed on the clay smears. The outputs for the smeared, glycolated, and heated slides were examined according to the University of Washington instructions to identify clay minerals. The minerals identified were tabulated qualitatively, and a figure was prepared displaying the graphical output for the air-dried clay smears for general visual comparison.

\section{Thin Section Point Counting}

Ten samples were prepared as thin sections to microscopically examine the lithologic characteristics of the two primary lithologic units beneath GAFB. In addition, two samples were selected from sands within the aquitard. These samples were selected from soil cores from boreholes for regional aquifer wells RZ-01 through RZ-04 (Fig. 15) 
installed by Montgomery Watson in 1994. Information regarding these samples is summarized in Table 2.

Table 2. Summary of samples tested using thin section point counting

\begin{tabular}{|c|c|c|c|}
\hline $\begin{array}{l}\text { Sample } \\
\text { Number }\end{array}$ & $\begin{array}{l}\text { Location and } \\
\text { Depth (bgs) }\end{array}$ & $\begin{array}{l}\text { Elevation } \\
\text { (ft msl) }\end{array}$ & Comments \\
\hline 1 & RZ-01 at 250 feet & 2.557 & $\begin{array}{l}\text { Shallow clay in southeast portion } \\
\text { of the base }\end{array}$ \\
\hline 2 & $R Z-01$ at 423 feet & 2,384 & $\begin{array}{l}\text { Deep clay in southeast portion } f \text { the } \\
\text { base }\end{array}$ \\
\hline 3 & RZ-02 at 146 feet & 2,696 & Sand above the aquitard \\
\hline 4 & $\mathrm{RZ}-02$ at 190 feet & 2,652 & Sand parting in the aquitard \\
\hline 5 & $R Z-02$ at 225 feet & 2,617 & Sand below the aquitard \\
\hline 6 & $R Z-03$ at 172 feet & 2,668 & Sand above the aquitard \\
\hline 7 & RZ-03 at 242 feet & 2,598 & Sand below the aquitard \\
\hline 8 & $R Z-04$ at 152 feet & 2.743 & Sand above the aquitard \\
\hline 9 & RZ-04 at 163 feet & 2,732 & $\begin{array}{l}\text { Sand parting in the aquitard; } \\
\text { subarkosic }\end{array}$ \\
\hline 10 & RZ -04 at 189 feet & 2,706 & $\begin{array}{l}\text { Sand below the aquitard; visible } \\
\text { volcanic grains }\end{array}$ \\
\hline
\end{tabular}

\section{Thin Section Preparation}

In order to isolate and emphasize the rock fragment sized particles in the sands, each sample was sieved using a number 10 U.S. standard sieve to separate material larger than 0.0787 inches $(2.0 \mathrm{~mm})$. The material passing the number 10 sieve was retained for thin sections. This material was washed on a number 40 sieve to eliminate material 
smaller than 0.0167 inches $(425 \mu \mathrm{m})$. Following a tap water wash, the samples were rinsed thoroughly with deionized water and oven dried in glass beakers.

The sieved samples were mixed with epoxy in plastic ice cube trays and heat-cured to harden. The samples were numerically labeled and submitted to Burnham Petrographics of Monrovia, California, where they were mounted on glass slides and ground to thin sections. Sample identification numbers were etched onto the edges of the slides by Burnham Petrographics.

\section{Point Counting}

To prevent bias while examining the samples, the etched labels were covered with masking tape. The slides were shuffled and re-labeled alphabetically. The slides were examined on a mechanical stage mounted on the rotating stage of an Olympus BHAmodel binocular polarizing microscope. Two hundred points were counted for each slide while moving the samples along longitudinal lines approximately $2.5 \mathrm{~mm}$ apart. Only those grains landing at the intersection of the eyepiece cross hairs were identified and described.

Rock fragments were classified as plutonic, volcanic, or metamorphic. Other classifications were made for single- and poly-crystalline quartz, altered and unaltered feldspar, and accessories. Fragments containing $90 \%$ or more of one mineral type were identified as minerals; otherwise, they were identified as rock fragments. The type of rock 
or mineral comprising accessories was identified when possible, however, individual categories were not created for accessories.

While some poly-crystalline quartz grains may be indicative of metamorphic rocks (e.g., quartzite), these grains were characterized as quartz mineral grains. Furthermore, quartz with undulose extinction was not ascribed to a particular rock type because fragments that exhibit this type of extinction occur in many types of metamorphic and plutonic rocks, and can be derived from most types of source terrains (Scholle, 1979).

The results of point counting were tabulated and, for each individual sample, the primary categories were each calculated as a percentage of the total. After examining numerous potential categorizations, the results were plotted on triangular diagrams. 


\section{RESULTS}

\section{$\underline{\text { Review of Existing Data }}$}

\section{Borehole Logs and Soil Cores}

Well drillers' logs were made with varying degrees of detail and suspected accuracy by a variety of drillers. The drillers' logs were primarily useful in identifying significant clay layers and the presence of groundwater. Logs from numerous local production wells and on-site test wells (Boyle Engineering Corp., 1987) record the presence of a number of "blue" and "green" clay layers interbedded in the deeper portions of the Lower Alluvial Unit. These clays are interpreted to be lacustrine deposits that record a history of significant Pleistocene lakes similar to those that formed the aquitard.

Based on their elevation and the "blue" and "green" appearance of thick clay units, several of the drillers' logs appear to indicate that the aquitard is present off-base. The aquitard appears to extend at least a mile north, west, and south-southwest of George AFB. These logs also appear to indicate that the perched aquifer is present throughout a similar area. At distances greater than a mile or so there is some evidence of the perched aquifer; however, evidence for the aquitard is inconclusive because thick clay units are prevalent over significant intervals, and it is difficult to determine if a distinguishable aquitard unit is present. 
While most of the well drillers' logs noted only the first water encountered (assumed to be the perched aquifer), the elevation and length of many of the well screens provide indirect evidence of deeper water-bearing units region wide.

The borehole logs from environmental investigations on GAFB were made using a variety of logging styles and soil classification systems, and they contained few notes providing reliable descriptive evidence for the presence of volcanics. Ultimately, little conclusive evidence was derived from these logs, with the exception of the logs for RZ-01 through RZ-04, which were logged using the Unified Soil Classification System (USCS) with a substantial amount of detail and consistency. In addition, continuous soil cores from these boreholes were available to the author to examine. The lithologic logs for RZ01 through RZ-04, which include geophysical (gamma-ray) logs, are presented in Appendix A.

Information regarding the depth, elevation, and thickness of the aquitard based on information from the " $R Z$ " borehole logs and soil cores is summarized in Table 3. It

Table 3. Aquitard and groundwater elevations in " $R Z$ " boreholes

\begin{tabular}{|c|c|c|c|c|c|c|}
\hline \multirow[b]{2}{*}{ Well Name } & \multirow{2}{*}{$\begin{array}{l}\text { Top of Well } \\
\text { Screen } \\
\text { Depth (ft) / } \\
\text { Elev. (ft ms) }\end{array}$} & \multicolumn{2}{|c|}{$\begin{array}{c}\text { Groundwater } \\
\text { Depth (ft)/Elev. (ft msl) }\end{array}$} & \multicolumn{3}{|c|}{ Aquitard Information } \\
\hline & & Drilling & Static & $\begin{array}{c}\text { Depth } \\
\text { (fi) }\end{array}$ & $\begin{array}{c}\text { Elev. } \\
\text { (ft msi) }\end{array}$ & $\begin{array}{l}\text { Thickness } \\
\text { (ft) }\end{array}$ \\
\hline RZ-01 & $408 / 2,399$ & $413 / 2,394$ & $210 / 2,597$ & $\begin{array}{l}150 \\
252\end{array}$ & $\begin{array}{l}2,657 \\
2,555\end{array}$ & $\begin{array}{l}19 \\
94\end{array}$ \\
\hline $\mathrm{RZ}-02$ & $310 / 2.532$ & $318 / 2,524$ & $258 / 2.584$ & 173 & 2.669 & 26 \\
\hline $\mathrm{RZ}-03$ & $257 / 2.583$ & $262 / 2,578$ & $253 / 2,587$ & 175 & 2.664 & 39 \\
\hline $\mathrm{RZ}-04$ & $313 / 2.582$ & $317 / 2,578$ & $309 / 2.586$ & 154 & 2.741 & 31 \\
\hline
\end{tabular}


should be noted that the term "aquitard", as used in Table 3 and throughout this discussion, refers to the distinctive unit characterized by olive-green laminated silt and massive brown clay. While there are other fine-grained perching horizons that could act as aquitards (specifically, in the vicinity of RZ-01), they do not display the characteristics of the main aquitard and are suspected to have origins different than that unit.

The RZ logs and selected well drillers logs are posted on Figures 16 through 18. Information from these logs was also used to create Figure 19, the interpreted regional extent and surface configuration of the aquitard, and Figure 20, the aquitard thickness. Figures 11 and 12, from the existing conceptual hydrogeologic model (Montgomery Watson, 1995), depict a more detailed interpretation of the aquitard's characteristics directly beneath GAFB, and are based on the assumption that the aquitard is one continuous unit beneath GAFB. Figures 19 and 20 are based on the interpretation that the aquitard is offset downward in the southeastern portion of GAFB. This interpretation accounts for the primary differences between Figures 11 and 12 and Figures 19 and 20. In addition, the interpreted thinning of the aquitard toward the east (Fig. 12) is not depicted on Figure 20 because detail supporting this interpretation was not contained in the well drillers' logs used to create Figure 20.

Volcanics are noted only on the logs for RZ-02 and RZ-04; however, they were observed by the author in the soil cores for all four of the 'RZ' boreholes. These clasts appear to be present only below the aquitard (Fig. 16). The volcanics are light 


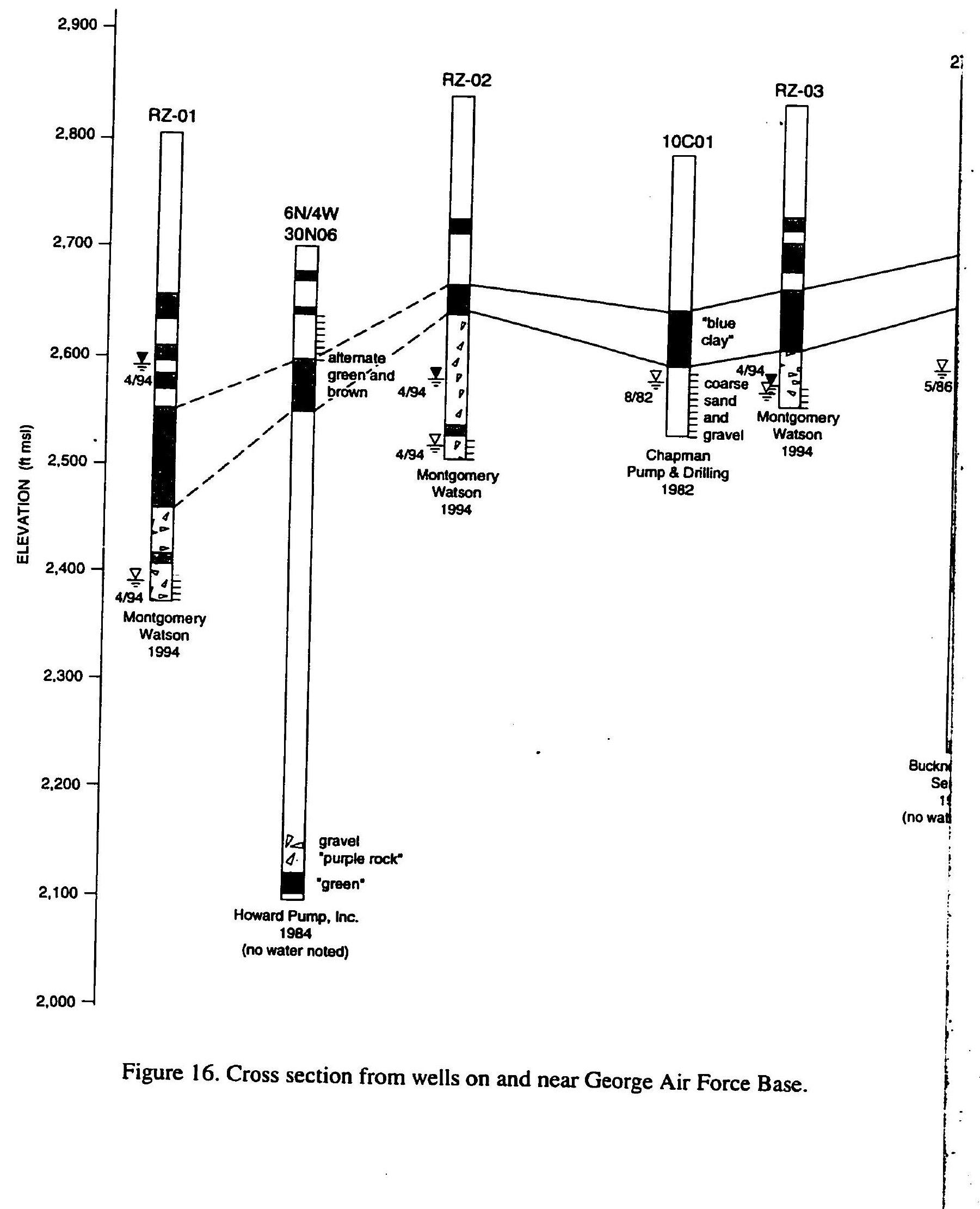




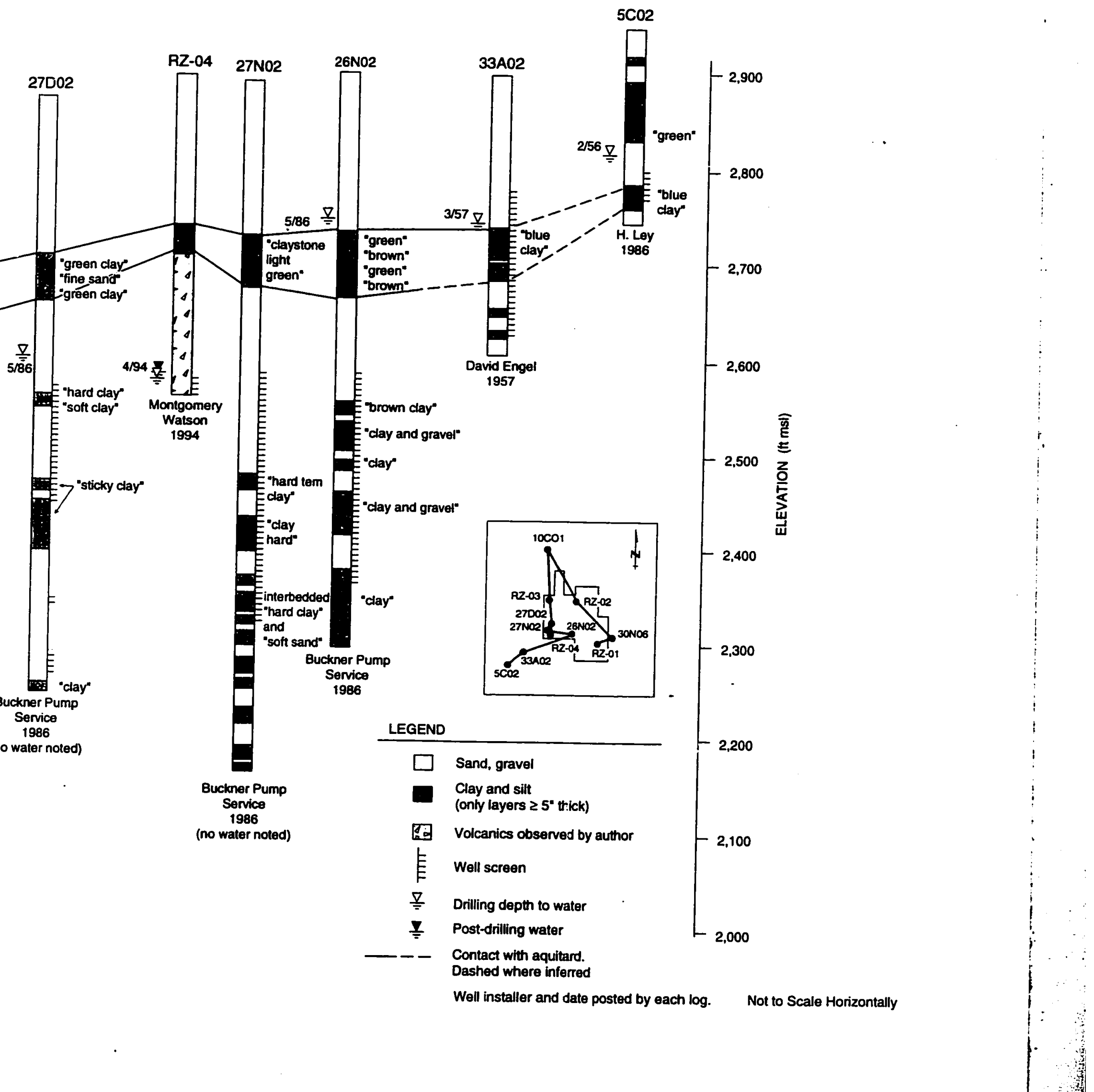




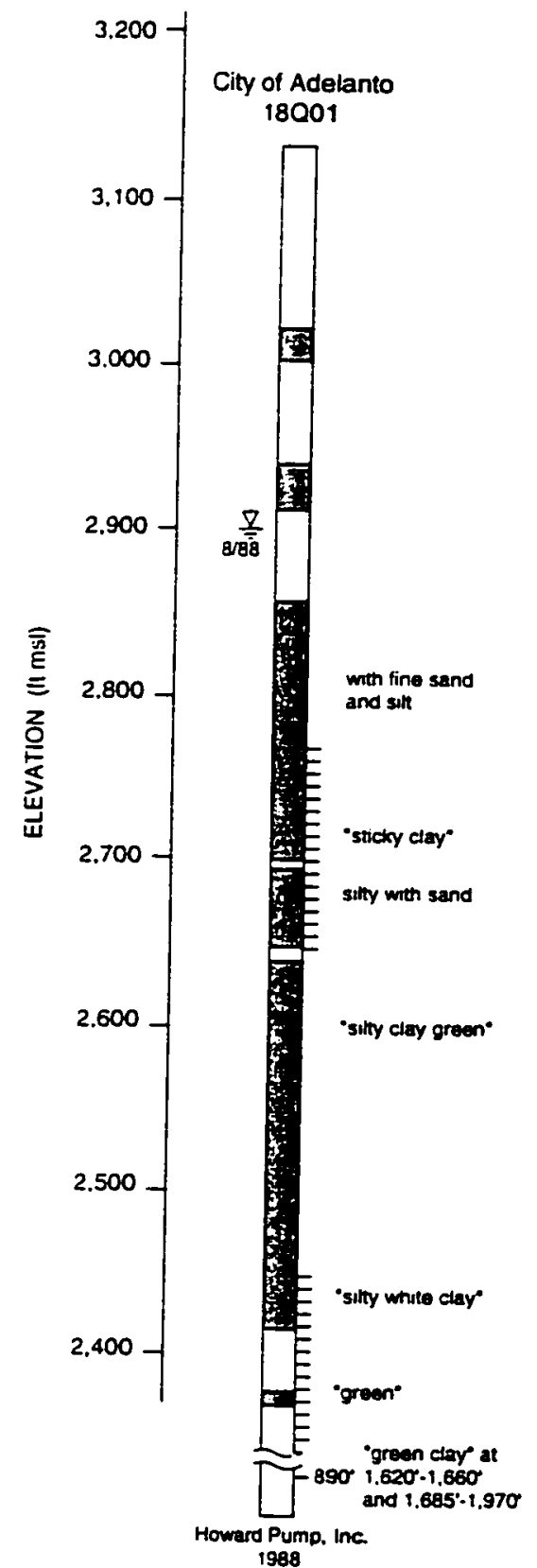

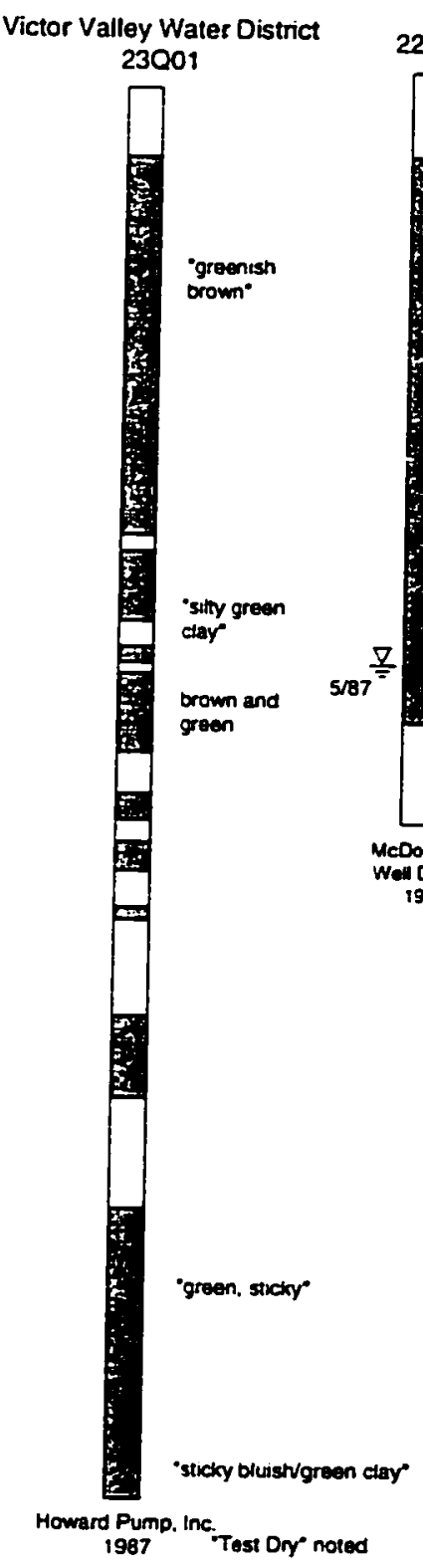

Figure 17. Cross section from wells south of George Air Force Base. 

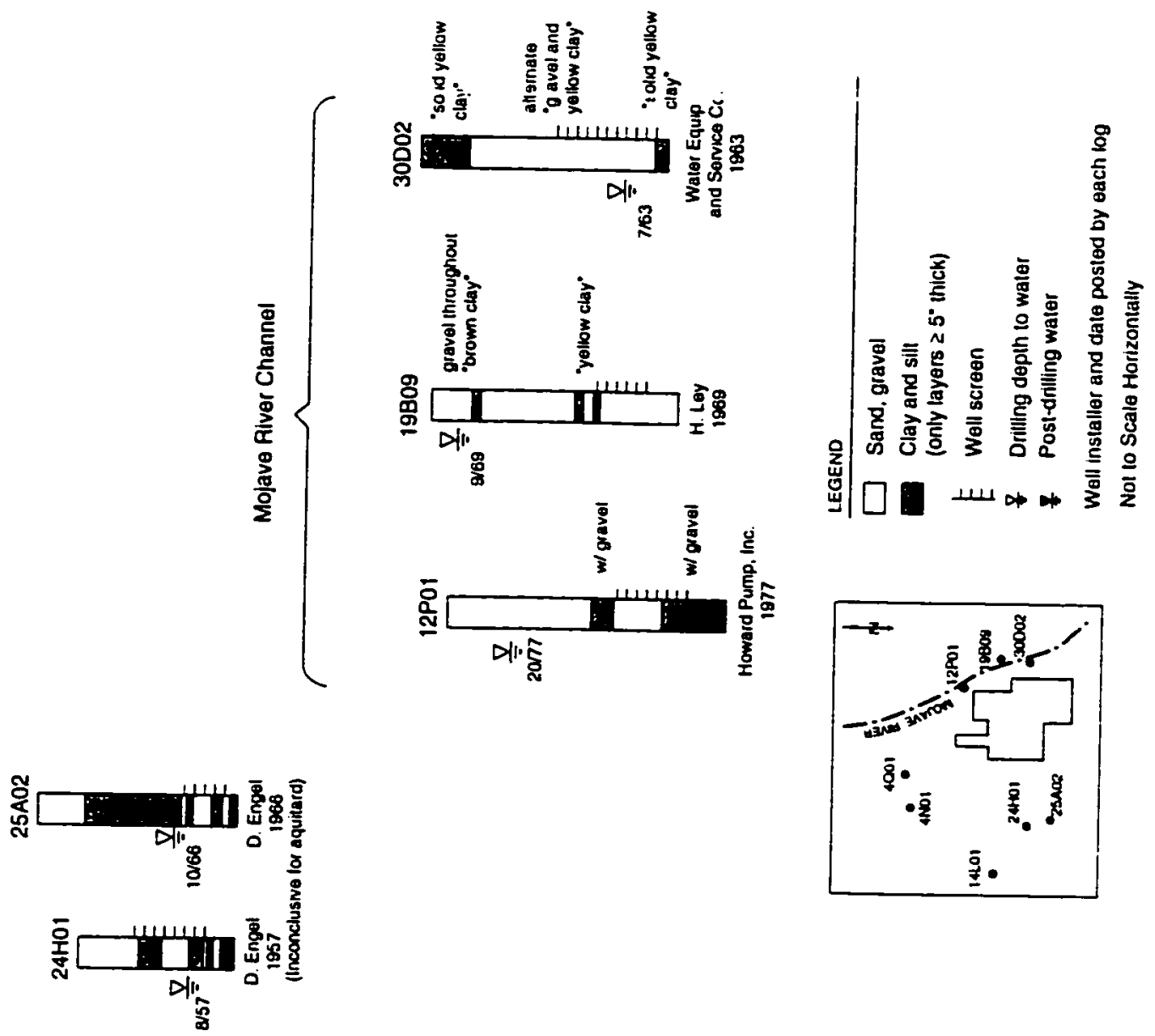

نే.

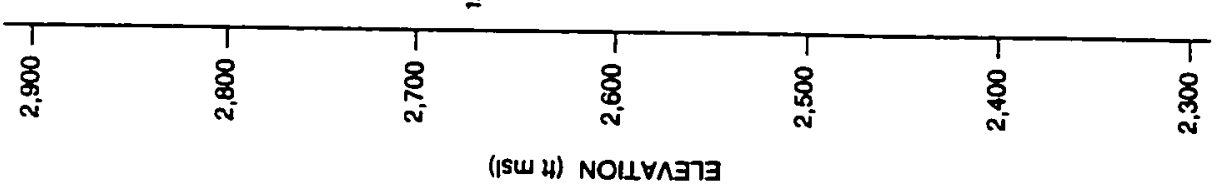



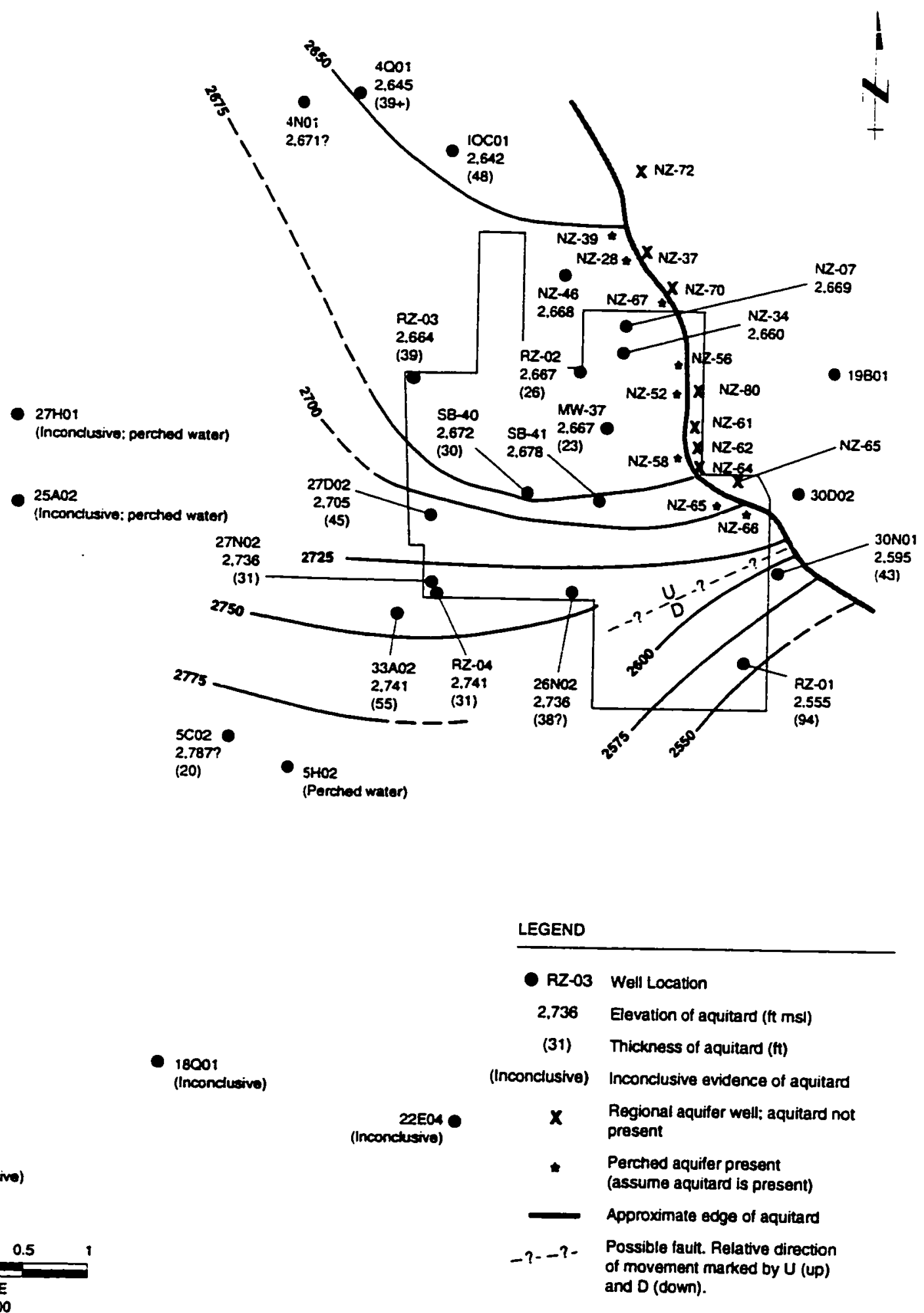

Figure 19. Interpreted regional extent and surface of the aquitard. 

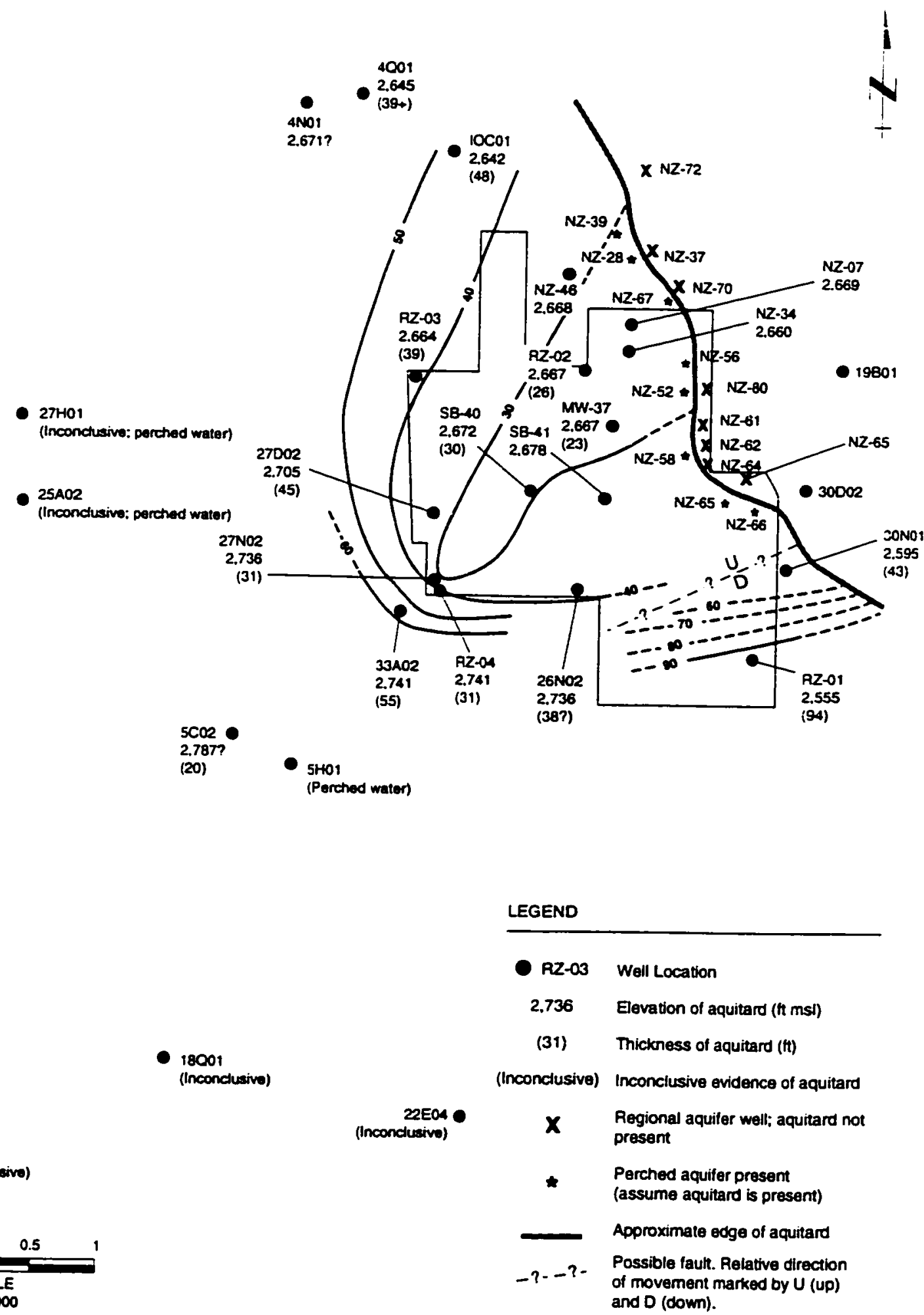

Figure 20. Interpreted thickness of the aquitard. 
purple-pink to dark purple-gray clasts with white feldspar laths. The clasts are typically subrounded to rounded and many are altered to a soft, clayey consistency. Flow banded textures are visible in some of the clasts. Other distinctive clasts in the Lower Alluvial Unit include hard, dark gray to black clasts whose compositions are difficult to identify due to their small size in the soil core samples, brown to red chert, and granule-sized clasts that appear to be epidote based on their bright, apple-green color.

The distinctively greenish-brown, laminated silt and massive brown clay indicative of the aquitard were observed at similar elevations in the soil cores for RZ-02, RZ-03, and RZ-04. In RZ-01, the fine-grained horizon noted as the aquitard in the existing model (Fig. 9) does not contain the distinguishing characteristics of the aquitard elsewhere - such as olive color, laminated silt, and brown clay. Rather, the unit in RZ-01 is a brown clayey silt, with trace coarse sand. In addition, the unit is only 19 feet thick, significantly thinner than elsewhere. Approximately 100 feet below the shallow fine-grained unit in RZ-01, however, there is a unit that strongly resembles the aquitard. The core sample from the deeper unit was observed to contain characteristic laminated silt and massive clay with brown and olive coloration.

The gamma log signatures for the $\mathbf{R Z}$ boreholes (Appendix A) render positive peaks in the presence of silts and clays. These peaks are typically 70 to $150 \mathrm{cps}$ higher than background readings. While the shallow fine-grained unit in RZ-0I did not produce a response above background readings, the deeper fine-grained unit created a signature 
roughly 90 to $150 \mathrm{cps}$ higher than background. The signature of the deeper unit in RZ-01 is similar to the signature rendered by the aquitard on the other logs, most notably that for RZ-03 (Appendix A). The reason for the narrow, low spikes within the aquitard signatures on the logs for RZ-01 at 286 feet and RZ-03 at 187 feet is unknown; however, they may be caused by sand units not noted in the borehole logs.

The well drillers' logs were examined to assess whether the deep clay unit in RZ01 is part of a deeper unit unrelated to the aquitard. While a number of deeper clays are logged, none is as thick as the deeper unit in RZ-01 or present at precisely the same elevation (Fig. 16).

An interesting finding is the presence of a thick, green to brown clay in well 30N06 near the southeastern boundary of GAFB (Fig. 16). The elevation of this clay is intermediate between the deep clay in RZ-0I and the aquitard beneath the rest of the base and appears to support the observation that the units in the southeastern portion of GAFB may be offset.

The primary findings from reviewing the borehole logs and the " $R Z$ " soil cores are that the aquitard appears to be regionally extensive in the vicinity surrounding GAFB, and that volcanics appear to be present only in sediments below the aquitard. In addition, the unit resembling the aquitard in the southeast portion of the base may be significantly deeper than elsewhere, possibly indicating offset in this area. 
Geotechnical Information

A summary of geotechnical information for water-bearing soils beneath GAFB is presented in Table 4. This information includes USCS classification, vertical hydraulic conductivity (from falling head permeability testing), and coefficient of uniformity $\left(C_{u}\right)$.

The $C_{v}$ values were used as a measure of the grain size distribution in the soils. A smaller $C_{u}$ indicates that soils are relatively well-sorted, whereas a larger $C_{u}$ indicates poor sorting. $C_{u}$ values for the perched aquifer (Upper Alluvial Unit) range from approximately 3 to 84 , with a geometric mean of 7.8. $C_{u}$ values for the regional aquifer (Lower Alluvial Unit) range from about 5 to 1,000 , with a geometric mean of 44.7. A comparison of $C_{u}$ values and USCS classifications indicates that perched aquifer soils are typically better sorted and contain less fine-grained material than soils of the regional aquifer.

The vertical hydraulic conductivity values for perched aquifer soils range from $0.0001 \mathrm{ft} /$ day to $4.25 \mathrm{ft} /$ day, with a geometric mean value of about $1.0 \times 10^{-1} \mathrm{ft} / \mathrm{day}$. Vertical hydraulic conductivities for the regional aquifer range from less than 0.0001 $\mathrm{ft} /$ day to $3.97 \mathrm{ft} /$ day, with geometric mean value of $3.1 \times 10^{-2} \mathrm{ft} / \mathrm{day}$.

Although no strong trends appear to be evident in the data, the relationship between vertical hydraulic conductivity and $\mathrm{C}_{\mathrm{u}}$ appears to indicate that poorly-sorted soils with higher percentages of fine materials generally have lower vertical permeabilities than well-sorted soils. These findings are presented on Figure 21. 
Table 4. Geotechnical information summary for water-bearing sediment

\begin{tabular}{|c|c|c|c|c|}
\hline $\begin{array}{c}\begin{array}{c}\text { Sample } \\
\text { Name }\end{array} \\
\text { PERCEID A }\end{array}$ & $\frac{\text { Depth (ft) }}{\text { FER }}$ & $\begin{array}{c}\text { USCS } \\
\text { Classification } \\
\end{array}$ & $\begin{array}{l}\text { Vertical } \\
\text { Hydraul. Conductivity } \\
\text { (ft/day) } \\
\end{array}$ & $\begin{array}{c}\text { Coefincient } \\
\text { of Uniformity }\left(C_{a}\right) \\
\end{array}$ \\
\hline \multicolumn{5}{|c|}{ PERCHED AQUTIFER } \\
\hline$N Z-68$ & 135.0 & SC & 0.0001 & 84.0 \\
\hline $\mathrm{NZ}-59$ & 144.0 & SM & 0.0015 & 22.4 \\
\hline WZ-03 & 132.0 & SP & 0.0065 & 4.9 \\
\hline$N Z-67$ & 70.0 & SM & 0.0156 & 16.3 \\
\hline $\mathrm{BZ}-05$ & 160.0 & SW-SM & 0.0397 & 7.7 \\
\hline SZ-07 & 168.0 & SW & 0.1077 & 6.8 \\
\hline WZ-02 & 130.0 & SP & 0.1871 & 4.7 \\
\hline WZ-01 & 130.0 & SP & 0.3969 & 5.0 \\
\hline BZ-02 & 160.0 & SW-SM & 0.4252 & 6.8 \\
\hline$N Z-56$ & 118.0 & SP-SM & 0.5669 & 58 \\
\hline SZ-11 & 96.5 & SP & 0.6236 & 3.1 \\
\hline SZ-08 & 166.5 & SP-SM & 1.3039 & 7.1 \\
\hline NZ-59 & 125.0 & SP-SM & 3.6850 & 3.7 \\
\hline SZ-09 & 93.5 & SP-SM & -4.2520 & 48 \\
\hline Geometric Me & & & 1.0. $\times 10^{-1}$ & 7.8 \\
\hline \multicolumn{5}{|c|}{ REGIONAL AQUTFER } \\
\hline NZ-74 & 148.5 & SC & 0.00004 & 233.3 \\
\hline$N Z-71$ & 190.0 & SM & 0.0001 & 243.3 \\
\hline RZ-OI & 420.0 & SC & 0.0001 & 140.0 \\
\hline$R Z-03$ & 266.5 & SC & 0.0003 & 292.9 \\
\hline $\mathrm{NZ}-73$ & 104.0 & SM & 0.0004 & 106.3 \\
\hline $\mathrm{NZ}-72$ & 211.0 & SM & 0.0009 & 688.9 \\
\hline NZ-73 & 110.5 & SM & 0.0028 & 846.2 \\
\hline NZ-71 & 159.5 & SM & 0.0043 & 28.6 \\
\hline NZ-74 & 142.5 & SM & 0.0045 & 70.0 \\
\hline NZ-70 & 141.5 & SM & 0.0142 & 1000.0 \\
\hline NZ-73 & 98.0 & SM & 0.0340 & 350.0 \\
\hline NZ-58 & 150.0 & SP-SM & 0.0510 & 5.1 \\
\hline RZ-04 & 322.0 & SC & 0.0624 & +1.4 \\
\hline $\mathrm{NZ}-64$ & 200.0 & SW-SM & 0.0992 & 7.4 \\
\hline$N Z-69$ & 141.5 & SW-SM & 0.1162 & 16.8 \\
\hline NZ-71 & 199.0 & SW-SM & 0.1247 & 6.1 \\
\hline $\mathrm{NZ}-74$ & 139.5 & SP-SM & 0.1276 & 34.0 \\
\hline RZ-02 & 312.0 & SW-SM & 0.1588 & 18.1 \\
\hline NZ-71 & 180.5 & SW-SM & 0.2070 & 6.7 \\
\hline$N Z-61$ & 283.5 & SP-SM & 0.5386 & 6.0 \\
\hline$N Z-62$ & 289.5 & SW-SM & 0.6803 & 38.3 \\
\hline $\mathrm{NZ}-64$ & 288.0 & SW-SM & 0.7370 & 7.5 \\
\hline $\mathrm{NZ}-60$ & 230.0 & SP-SC & 2.6646 & 46.5 \\
\hline NZ-57 & 114.0 & SW-SM & 2.7496 & 14.4 \\
\hline NZ-60 & 293.5 & SP-SM & 3.9685 & 5.0 \\
\hline \multirow[t]{2}{*}{ NZ-62 } & 170.0 & SM & 3.9685 & 20.9 \\
\hline & & Gcometric hean: & $3.1 \times 10^{-2}$ & 4.7. \\
\hline \multirow{2}{*}{\multicolumn{5}{|c|}{$\begin{array}{l}\text { Information Source: Montgomary Warson, } 1995 \\
\text { Notes: } \\
\text { USCS = Unified Soils Classification System }\end{array}$}} \\
\hline & & & & \\
\hline \multicolumn{5}{|c|}{ Vertical hydraulic conductivity values derived from laboratory falling head permeameter tests. } \\
\hline
\end{tabular}



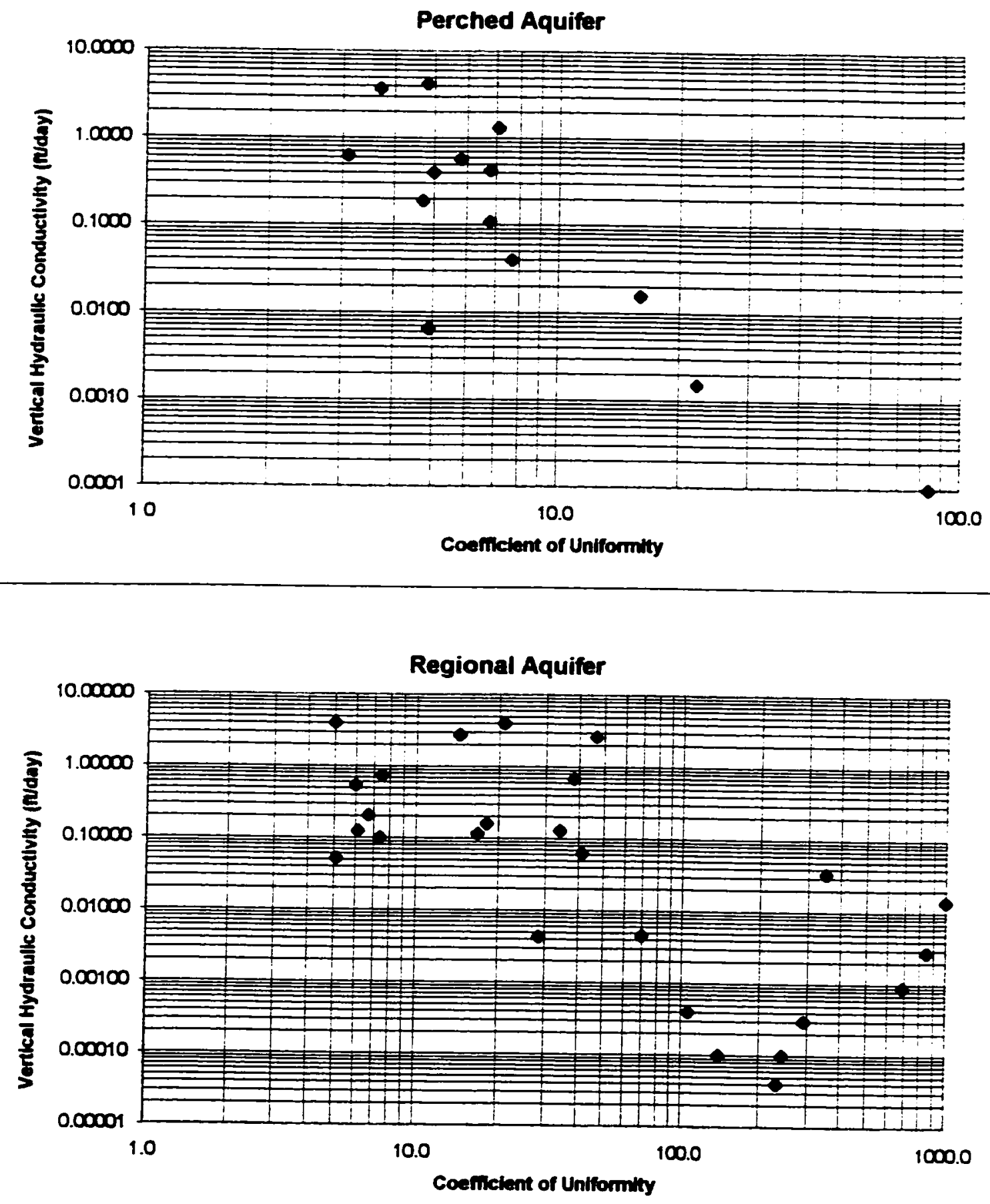

Figure 21. Coefficient of Uniformity versus vertical hydraulic conductivity for perched and regional aquifer sediments 
It was initially anticipated that the regional aquifer sediments, suspected of being locally derived, would contain a predominance of coarse-grained sediments and, therefore, would display relatively high hydraulic conductivities. The hydraulic conductivities of the perched aquifer were expected to be lower because of a greater suspected lithologic heterogeneity. It was interesting to find that the opposite was true. Perhaps these findings indicate that the perched aquifer soils were sorted over distance and much of the fine grained material was removed. The higher percentages of fines in the regional aquifer soils may be indicative of the fluvial and lacustrine environments that existed locally during their deposition.

\section{Aquifer Testing Data}

A variety of aquifer tests ranging from slug tests to long-term pumping tests were performed to estimate aquifer characteristics at GAFB. The first known aquifer tests for the GAFB area were performed by Boyle Engineering Corp. (1987) in production wells screened in the regional aquifer. Numerous other tests have been performed in both the perched and regional aquifers by Montgomery Watson (JMM, 1992; Montgomery Watson, 1995), and by IT Corp. (IT Corp., 1992). The results of these tests are summarized in Table 5. The distributions of hydraulic conductivity $(\mathrm{K})$ values from aquifer tests in the regional and perched aquifers beneath GAFB are presented on Figures 22 and 23 , respectively. 
Table 5. Summary of aquifer test results, George Air Force Base, California

\begin{tabular}{|c|c|c|c|c|c|c|c|c|c|}
\hline Well & $\begin{array}{c}\text { Test } \\
\text { Method } \\
\end{array}$ & $\begin{array}{c}T \\
\left(f^{2} / d a y\right)\end{array}$ & $\begin{array}{c}\mathbf{K} \\
\text { (ft/day) }\end{array}$ & $\mathbf{s}$ & Well & $\begin{array}{c}\text { Test } \\
\text { Method } \\
\end{array}$ & $\begin{array}{c}T \\
\left(f^{2} / d a y\right)\end{array}$ & $\begin{array}{c}\bar{K} \\
\text { (ft/day) }\end{array}$ & $\mathbf{S}$ \\
\hline \multicolumn{5}{|c|}{ PERCHED AQUIFER } & \multicolumn{5}{|c|}{ REGIONAL AQUTHER } \\
\hline $\mathrm{BZ}-0 \mathrm{I}$ & $S^{(\mathbf{s})}$ & 1 & 0.01 & NA & EW-7 & $\mathrm{L}^{(0)}$ & 5,904 & 84.30 & NA \\
\hline $\mathrm{BZ}-02$ & $S^{(a)}$ & 78 & 1.11 & NA & EW-14 & $L^{(0)}$ & 2,160 & 20.90 & NA \\
\hline $\mathrm{BZ}-03$ & $S^{(a)}$ & 133 & 5.30 & NA & $E W-15$ & $L^{(0)}$ & 1,872 & 18.70 & $+3 \times 10^{-3}$ \\
\hline$B Z-04$ & $S^{(\boldsymbol{a})}$ & 0 & 0.01 & NA & EW-16 & $L^{(D)}$ & 1,843 & 18.50 & 128 \\
\hline$B Z-06$ & $\mathbf{S}^{(\boldsymbol{\omega})}$ & 0 & 0.01 & NA & EW-17 & $L^{(b)}$ & 12,672 & 126.40 & NA \\
\hline EW-3 & $L^{(b)}$ & 1,421 & 25.80 & $2.2 \times 10^{-4}$ & $E W-18$ & $L^{(b)}$ & 18,720 & 186.60 & NA \\
\hline FT-04 & $S^{(2)}$ & 2,005 & 40.11 & NA & MW-107 & $\mathrm{L}^{(0)}$ & 14,256 & 143.20 & $3.5 \times 10^{-4}$ \\
\hline MW-27 & $\mathbf{S}^{(a)}$ & 1,695 & 24.22 & NA & MW-108 & $L^{(b)}$ & 22,176 & 221.20 & $2.9 \times 10^{-4}$ \\
\hline$M W-40$ & $\mathbf{S}^{(\mathbf{a})}$ & 1,478 & 21.12 & NA & NZ-13 & $S^{(\mathbf{b})}$ & 840 & 12.00 & NA \\
\hline$M W-42$ & $S^{( \pm)}$ & 4,993 & 71.33 & $\mathrm{NA}$ & NZ-57 & $\mathbf{S}^{(\boldsymbol{})}$ & 966 & 13.80 & NA \\
\hline MW-51 & $S^{(\Delta)}$ & 2.094 & 29.92 & NA & $N Z-60$ & $\mathbf{S}^{(\mathbf{( 1 )}}$ & 1,938 & 32.30 & $\mathrm{NA}$ \\
\hline MW-57 & $\mathbf{S}^{(\mathbf{a})}$ & 2,348 & 33.54 & NA & $N Z-61$ & $S^{(a)}$ & 546 & 9.10 & NA \\
\hline MW-58 & $\mathbf{S}^{(\boldsymbol{\omega})}$ & 3.744 & 53.48 & NA & $N Z-62$ & $\mathbf{S}^{(\mathbf{a})}$ & 2,592 & 43.20 & NA \\
\hline NZ-35 & $\mathbf{S}^{(\mathbf{e s})}$ & 5,251 & 80.78 & NA & $N Z-64$ & $S^{(\mathbf{a})}$ & 0.3 & 0.005 & NA \\
\hline NZ-36 & $S^{(2)}$ & 1,390 & 21.38 & NA & $N Z-65$ & $S^{(\mathbf{a})}$ & 6.0 & 0.10 & NA \\
\hline$N Z-43$ & $S^{(\mathbf{a})}$ & 1,566 & 26.10 & NA & NZ-69 & $\mathrm{L}^{(b)}$ & 6,048 & 60.20 & $1.2 \times 10^{-3}$ \\
\hline NZ-55 & $S^{(2)}$ & 1,051 & 21.02 & NA & NZ-71 & $\mathrm{L}^{(D)}$ & 11,761 & 117.60 & $8.7 \times 10^{-1}$ \\
\hline$N Z-56$ & $\mathbf{S}^{(\boldsymbol{a})}$ & 1 & 0.02 & NA & NZ-72 & $\mathbf{S}^{(\mathbf{( 1 )}}$ & NA & 4.92 & NA \\
\hline NZ-59 & $\mathbf{S}^{(\mathbf{a})}$ & 12 & 0.23 & NA & NZ-73 & $S^{(2)}$ & 3,326 & 47.50 & NA \\
\hline$N Z-63$ & $\mathbf{S}^{(\boldsymbol{a})}$ & 16 & 0.35 & NA & NZ-74 & $\mathbf{S}^{(\mathbf{a})}$ & 173 & 2.47 & NA \\
\hline$N Z-66$ & $S^{(2)}$ & 186 & 12.40 & NA & NZ-76 & $\mathrm{I}^{(b)}$ & 2,016 & 20.20 & $1.6 \times 10^{-3}$ \\
\hline$N Z-67$ & $\mathbf{S}^{(\mathbf{a})}$ & 17 & 1.73 & NA & NZ-77 & $L^{(b)}$ & 2,160 & 21.10 & $3.9 \times 10^{-4}$ \\
\hline NZ-68 & $\mathbf{S}^{(\mathbf{a})}$ & 635 & 12.70 & NA & NZ-78 & $\mathrm{L}^{(b)}$ & 9,504 & 95.60 & $2.7 \times 10^{-4}$ \\
\hline SZ-06 & $S^{(2)}$ & 58 & 1.92 & NA & NZ-79 & $L^{(0)}$ & 12,816 & 127.60 & $1.4 \times 10^{-3}$ \\
\hline SZ-07 & $S^{(a)}$ & 16 & 0.45 & NA & $R Z-01$ & $\mathbf{S}^{(\mathbf{e})}$ & 418 & 5.97 & NA \\
\hline SZ-08 & $S^{(\mathbf{a})}$ & 648 & 18.51 & NA & RZ-02 & $\mathbf{S}^{(\boldsymbol{)})}$ & 691 & 9.87 & NA \\
\hline SZ-09 & $\mathbf{S}^{(\boldsymbol{a})}$ & 151 & 4.32 & NA & RZ-03 & $S^{(2)}$ & 346 & 4.94 & NA \\
\hline$S Z-10$ & $\mathbf{S}^{(\mathbf{a})}$ & 20 & 0.58 & NA & $R Z-04$ & $L^{(b)}$ & 3,082 & 30.80 & NA \\
\hline$S Z-11$ & $S^{(\mathbf{a})}$ & 12 & 0.21 & NA & \multirow{2}{*}{\multicolumn{2}{|c|}{ Geometric Mean: }} & 1,175 & 17.78 & $2.1 \times 10^{5}$ \\
\hline SZ-12 & $\mathbf{S}^{(\mathbf{e})}$ & 1,887 & 34.30 & NA & & & & & \\
\hline$S Z-13$ & $S^{(2)}$ & 2 & 0.04 & NA & & & & & \\
\hline SZ-14 & $S^{(\mathbf{a})}$ & 245 & 8.16 & NA & & & & & \\
\hline$W Z-04$ & $S^{(2)}$ & 148 & 1.98 & NA & & & & & \\
\hline WZ-0S & Slug & NA & 0.55 & NA & & & & & \\
\hline$w Z-06$ & Slug & NA & 2.28 & NA & & & & & \\
\hline \multicolumn{2}{|c|}{ Geometric Menn: } & 112 & 1.1 & $2.2 \times 10^{5}$ & & & & & \\
\hline
\end{tabular}

Notes:

$\mathrm{T}=\mathrm{Transmissivity}$

$S=$ Storativity

$\mathrm{K}=$ Hydraulic Conductivity

$\mathrm{NA}=$ Not determined

(a) $S$ = Step test; duration approximately 4 hours

${ }^{\text {b }} \mathrm{L}=$ Long-term test, duration approximately 24 to 72 hours 


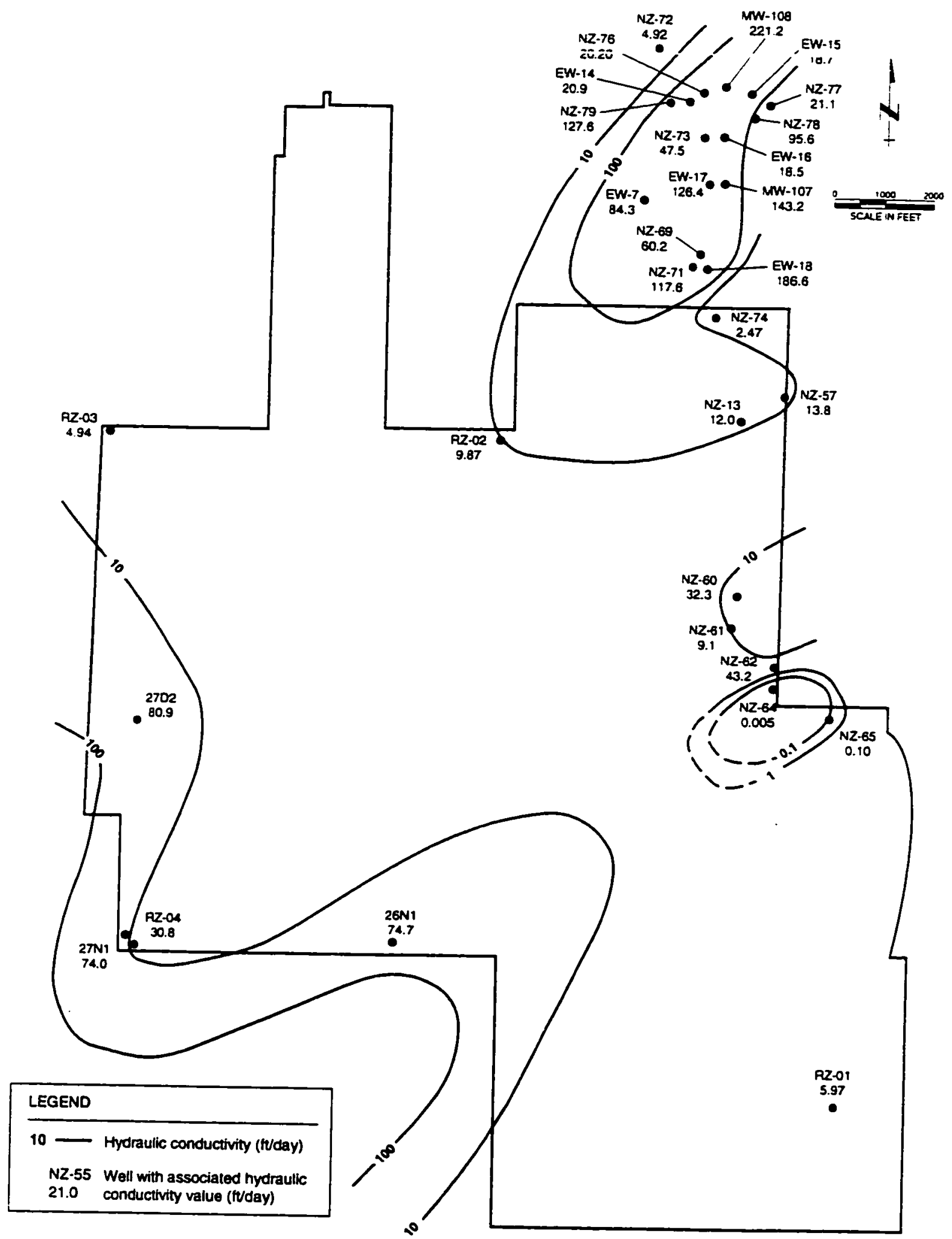

Figure 22. Hydraulic conductivity distribution for the regional aquifer. Data for individual wells from Montgomery Watson (1995). 


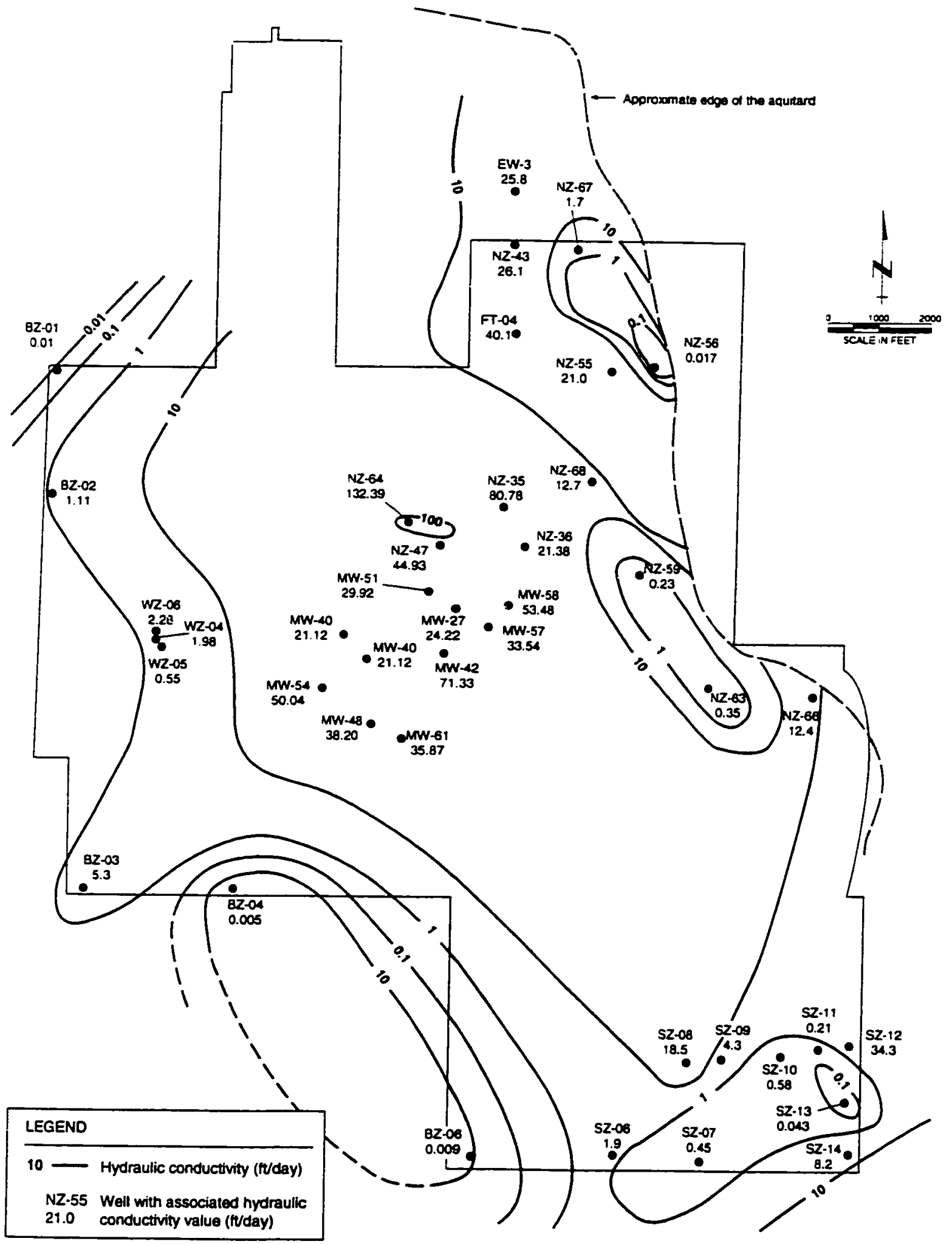

Figure 23. Hydraulic conductivity distribution for the perched aquifer.

Data for individual wells from Montgomery Watson (1995) and IT Corp. (1992). 
Because of the variety of aquifer testing methods used and the widely different outcomes of tests in the same aquifer conducted by different firms, the reliability of the aquifer test results are questionable. For example, hydraulic conductivities collected by slug tests and long-term tests may not be directly comparable. Regardless of potential weaknesses in the data, some general comparisons were made.

$\mathrm{K}$ estimates for the regional aquifer range from about $0.005 \mathrm{ft} /$ day to $221 \mathrm{ft} /$ day, with a geometric mean of $17.8 \mathrm{ft} /$ day. Some of the low $\mathrm{K}$ values estimated from shortterm regional aquifer tests are suspected to be due to low transmissivity estimates resulting from turbulent well losses and reduction in the saturated well bore interval due to excessive drawdown (Montgomery Watson, 1995). The distribution of $\mathrm{K}$ values in the regional aquifer indicates a southwest- to northeast-trending zone of high $\mathrm{Ks}$ in the northeastern portion of the base. The shape of the current TCE plume in the regional aquifer reflects this zone of high values, which facilitates TCE migration beneath the wastewater treatment plant and toward the Mojave River (Fig. 6). The zone of high $\mathrm{K}$ values may represent buried channels of coarser sediments and/or inter-fingered deposits of the Mojave River. The lack of detail in the central and western portions of the base on Figure 22 reflects the general lack of hydrogeologic data for these areas.

Mean storativity estimates for the regional aquifer beneath GAFB range from about 0.0003 to 0.004 , indicating partially confined to unconfined conditions beneath most 
of the base (Montgomery Watson, 1995). The regional aquifer may be locally semiconfined. For example, water was encountered during drilling for RZ-02 at approximately 318 feet bgs, and subsequently rose 60 feet to 258 feet. This occurrence may have been partially due to slow groundwater entrance into the borehole and/or clay smearing during drilling of RZ-02. The regional aquifer appears to be fully confined in the southeastern portion of the base in the vicinity of RZ-01. Regional aquifer groundwater in this borehole was encountered below the deep clay and silt unit (depth approximately 252 feet), approximately 100 feet deeper than in the other $R Z$ boreholes. The groundwater subsequently rose to elevations similar to, although slightly higher than, elevations observed in other regional aquifer wells at GAFB.

Hydraulic conductivity values for the perched aquifer range from approximately $0.01 \mathrm{ft} /$ day to $80.8 \mathrm{ft} /$ day with a geometric mean of $1.1 \mathrm{ft} /$ day. The highest perched aquifer $K$ values are in the eastern portions of GAFB, with values decreasing westward A zone of low $\mathrm{K}$ values also exists in a northwest- to southeast-trending zone in the northeastern portion of the base (Fig. 23). According to information from tests performed by IT Corp., there is a northwest-trending zone of high permeability in the central portion of GAFB, which is interpreted by IT Corp. (1992) as indicating potential buried stream channels.

The mean hydraulic conductivity of the regional aquifer is more than ten times greater than the perched aquifer. The distribution of hydraulic conductivity zones also 
varies noticeably between the two aquifers. Zones in the regional aquifer appear to display a southwest to northeast trend, while zones in the perched aquifer appear to display southeast to northwest trend. The lower hydraulic conductivity values for the perched aquifer may be due to the fact that they were primarily determined by short-term step tests, which frequently render underestimated conductivity values.

While $\mathrm{K}$ values from aquifer tests are greater in the regional aquifer, this is not the case for vertical hydraulic conductivities (discussed in the section above), where values for the perched aquifer are typically greater than in the regional aquifer. Despite this contrast, the higher overall $\mathrm{K}$ values for the regional aquifer are likely the result of the greater transmissivity values of regional aquifer sediments due, at least in part, to greater saturated thicknesses.

Water Levels

Since environmental investigations began at GAFB in the early 1980's, the elevation of the regional aquifer beneath the base has been approximately 2,585 feet msl. According to water levels recorded since the 1980 's, regional groundwater elevations beneath GAFB have dropped an average of approximately 2 feet over the past 9 years. This drop may be partially due to groundwater pumping for remediation, which began in 1991 in the northwestern portion of GAFB. Figure 24 displays hydrographs for representative regional aquifer wells based on water levels measured during environmental investigations at GAFB. 


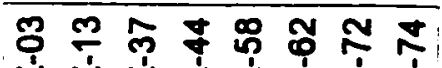

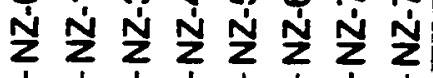

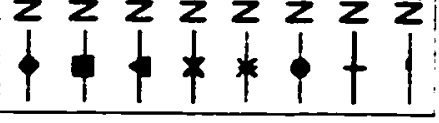

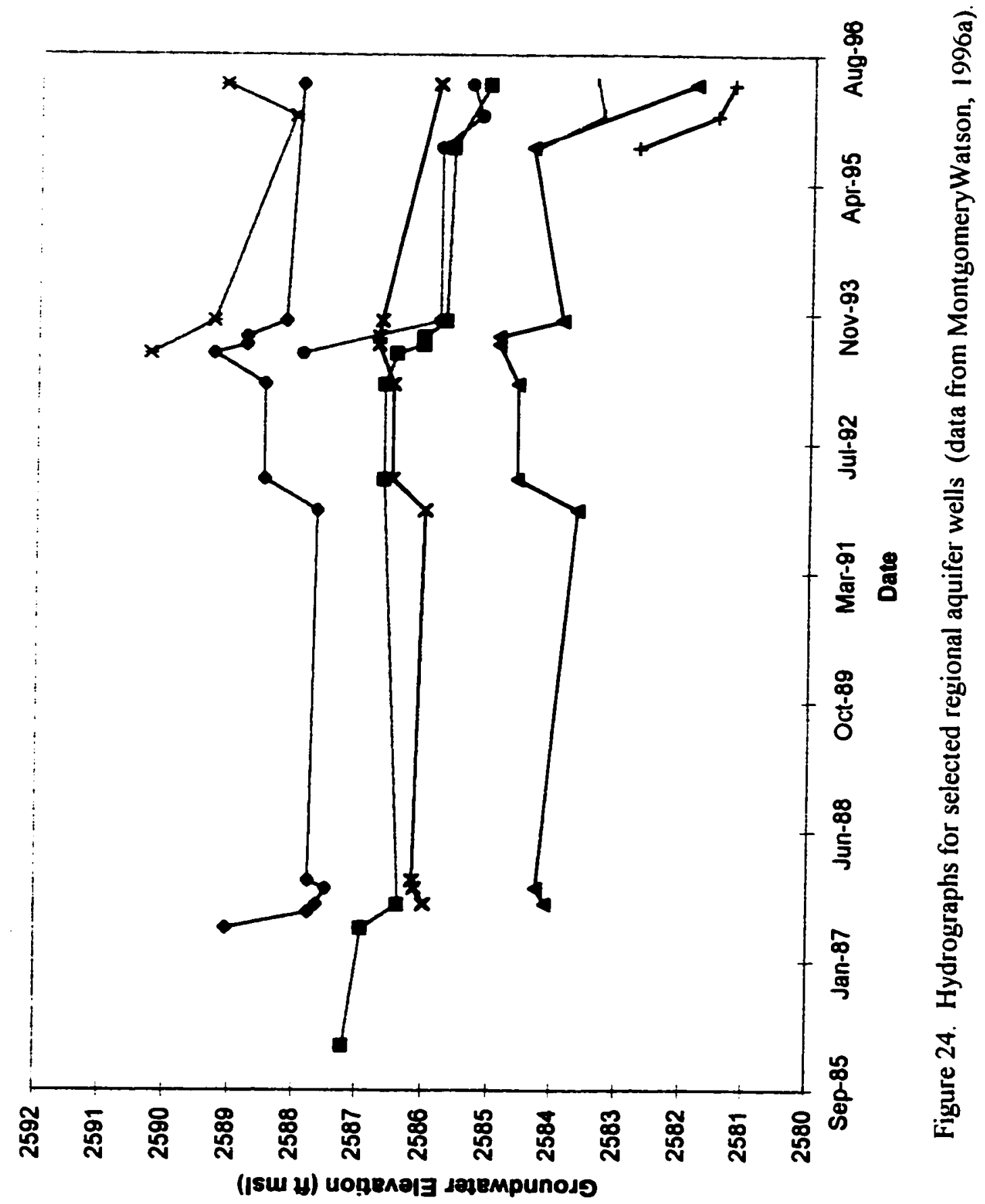




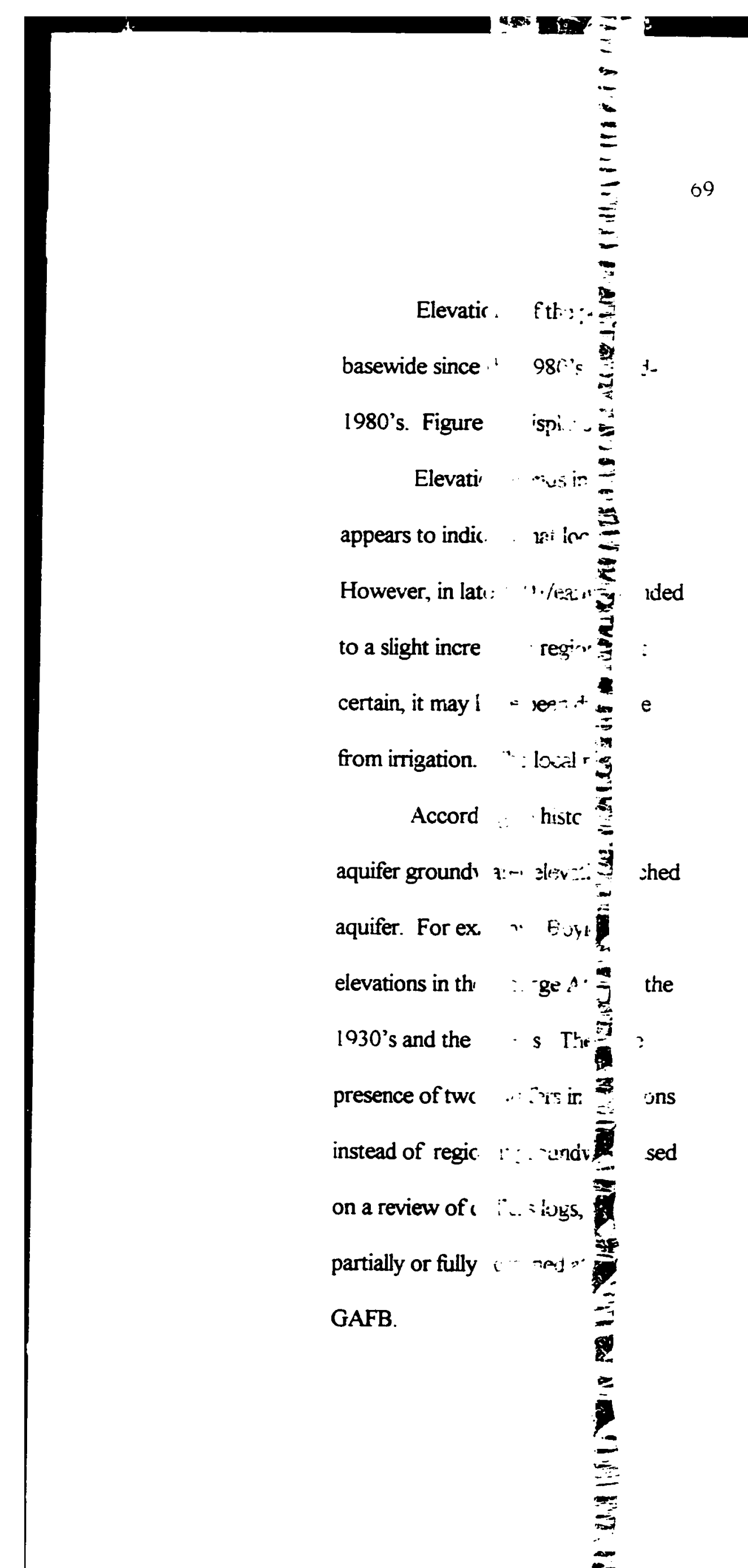


Elevations of the perched aquifer have been between 2,720 and 2,750 feet msl basewide since the 1980's. Water levels have declined approximately 4 feet since the mid1980's. Figure 25 displays hydrographs of selected perched aquifer wells.

Elevation trends in the perched and regional aquirers are generally similar, which appears to indicate that local seasonal precipitation influences both aquifers similarty. However, in late 1991/earty 1992 a slight decrease in perched aquifer elevations corresponded to a slight increase in regional aquifer elevations. While the cause of this occurrence is not certain, it may have been due to base closure and the subsequent decrease in local recharge from irrigation. The local recharge to the perched aquifer is further discussed below.

According to historical groundwater measurements for the Victor Valley, regional aquifer groundwater elevations were once as high as elevations measured today in the perched aquifer. For example, Boyle Engineering Corp. (1987) reports that regional groundwater elevations in the George AFB area were between about 2,750 and 2,700 feet msl between the 1930 's through the 1960's. The authors of past regional studies may have failed to identify the presence of two aquifers in the area and erroneousty reported perched groundwater elevations instead of regional groundwater elevations throughout the Upper Mojave River Basin. Based on a review of drillers logs, most of the area's large and municipal production wells are partially or fully screened at elevations far below the thin perched stratum found beneath GAFB. 


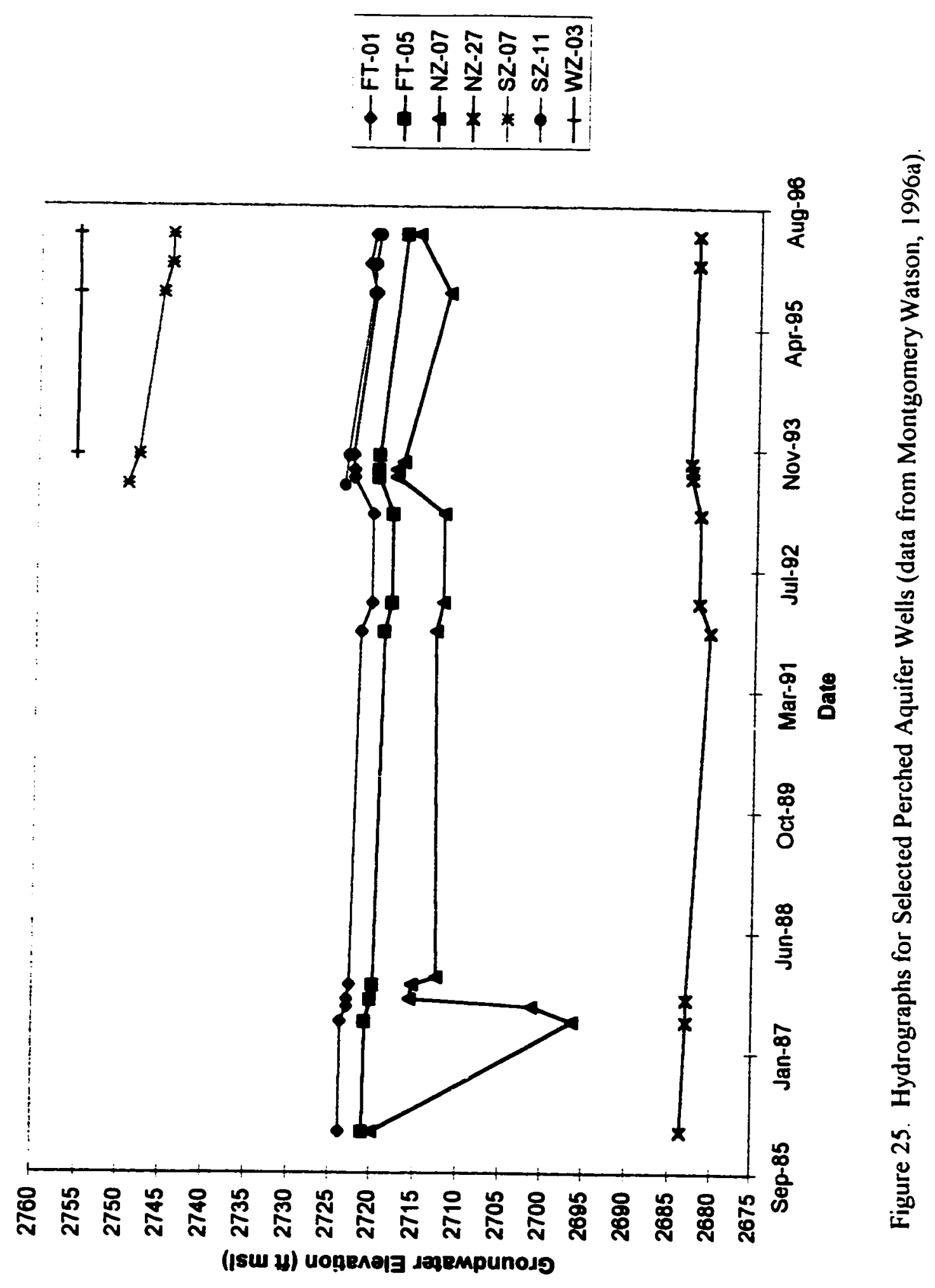


Following significant population growth in the Victorville area, the regional system may have been significantly de-watered, essentially resulting in the perched aquifer becoming "stranded" above the aquitard. The perched aquifer appears to persist in the vicinity extending roughly 1 mile north, south, and west of GAFB. This observation is based on well drillers' logs from the mid-1950's through the late 1980's that record groundwater at elevations similar to the perched aquifer beneath GAFB (Figs. 16, 17, and 18).

Because of slow recharge rates in this portion of the Mojave River groundwater basin, the perched aquifer may be partially sustained by anthropogenic recharge including septic tanks in the city of Adelanto, west of the base, and by irrigation and water losses at GAFB. This belief is held by some personnel of the USGS (P. Martin, oral communication, 1996).

Despite base closure, irrigation of the golf course and landscaping around main roads and occupied buildings has continued. In addition, unsubstantiated reports by GAFB maintenance personnel indicate that up to 10,000 gallons per day of water are lost through leaks in the GAFB water conveyance system. Furthermore, the author has observed that chemical analyses of perched aquifer water samples at GAFB have consistently detected low concentrations (approximately 0.5 to $2 \mu \mathrm{g} / \mathrm{L}$ ) of chloroform, a common component of treated drinking water. These findings may provide indirect evidence that treated water is recharging the perched aquifer. Chloroform has rarely been detected in regional aquifer samples.

Historical water level declines in the perched aquifer are likely the result of decreased recharge following base closure and withdrawals from local private wells and the OU 1 pump 
and treat system Much of the water removed and treated by the system is returned via percolation to the perched aquifer, however, percolation has historically been in the northeastern portion of the base near the edge of the aquitard, where losses occur from the perched to the regional aquifer.

\section{Water Quality}

Background concentrations of metals in the perched aquifer were calculated by Montgomery Watson using the data from wells upgradient from known potential contaminant sources (Montgomery Watson, 1996a). A statistically significant number of samples is not available to assess background concentrations for the regional aquifer, therefore, average metal concentrations were estimated. These concentrations are presented in Table 6.

A comparison of average concentrations of metals in the perched and regional aquifers is presented on Figure 26. In general, average metal concentrations in the regional aquifer are higher than in perched aquifer. The most extreme differences were observed in manganese and iron, but barium, calcium, and sodium are also found in higher average concentrations in the regional aquifer. Vanadium and aluminum are present in slightly higher concentrations in the perched aquifer.

Stiff and Piper diagrams for the regional and perched aquifers are presented on Figures 27 and 28, respectively. According to these diagrams, the regional aquifer in the 
Table 6. Mean and background concentrations of selected constituents in groundwater, Ǵeorge Air Force Base.

\begin{tabular}{|c|c|c|c|c|}
\hline \multirow[b]{2}{*}{ Constituent } & \multicolumn{2}{|c|}{ PERCHED AQUIFER } & \multicolumn{2}{|c|}{ REGIONAL AQUTFER } \\
\hline & Mean (mg/L) & \begin{tabular}{|c|} 
Maximum Background \\
Concentration (mg/L) (a)
\end{tabular} & Mean (mg/L) & $\begin{array}{c}\text { Background } \\
\text { Range (mg/L) (b) }\end{array}$ \\
\hline Aluminum & 2.5 & 11 & 2.096 & $0.1-0.296$ \\
\hline Antimony & NA & $9.06(\mathrm{c})$ & - & - \\
\hline Arsenic & 0.004 & 0.01 & 0.0066 & 0.04 \\
\hline Barium & 0.052 & 0.12 & 0.0758 & 0.145 \\
\hline Beryllium & NA & 0.002 (c) & 0.002 & - \\
\hline Cadmium & NA & $0.005(c)$ & - & $0.005(c)$ \\
\hline Calcium & 22.5 & +4.3 & 41.27 & $1.3-64.5$ \\
\hline Chromium & 0.009 & 0.03 & 0.0151 & 0 \\
\hline Cobalt & NA & $0.01(c)$ & 0.01 & - \\
\hline Copper & NA & $0.04(\mathrm{c})$ & 0.0349 & $0.02-0.363$ \\
\hline Iron & 2.8 & 12 & 23.685 & $0.04-3.307$ \\
\hline Lead & NA & $0.005(c)$ & 0.0083 & $0.026-0.043$ \\
\hline Magnesium & 5.4 & 11 & 6.013 & $1.2-16$ \\
\hline Manganese & 0.08 & 0.4 & 0.4118 & $0.03-0.8$ \\
\hline Mercury & NA & $0.0002(c)$ & - & 0 \\
\hline Molybdenum & NA & $0.02(\mathrm{c})$ & - & - \\
\hline Nickel & NA & $0.04(\mathrm{c})$ & 0.0438 & - \\
\hline Potassium & NA & $5(c)$ & 7.6 & $0.5-4.8$ \\
\hline Selenium & NA & $0.005(c)$ & - & 0.046 \\
\hline Silver & NA & $0.01(\mathrm{c})$ & - & $0.01(\mathrm{c})$ \\
\hline Sodium & 74 & 125 & 121.1 & $30.6-112$ \\
\hline Thallium & NA & 0.002 (c) & - & - \\
\hline Vanadium & 0.033 & 0.071 & 0.025 & - \\
\hline Zinc & 0.04 & 0.1 & 1.7 & $0.05-2.08$ \\
\hline
\end{tabular}

Notes:

NA = Not applicable; constituent not detected in tested samples. Background is laboratory detection limit.

$\mathrm{mg} / \mathrm{L}=$ milligrams per liter

(a) Based on statistical calculations from data collected by Montgomery Watson (1996a). Values represent the maximum concentrations computed for background ranges (Montgomery Watson, 1996a).

(b) Background statistical calculations not pertormed due to small number of representative samples from regional aquifer wells (Montgomery Watson, 1996a).

(c) Laboratory detection limit used as background value if constituent was not detected. 

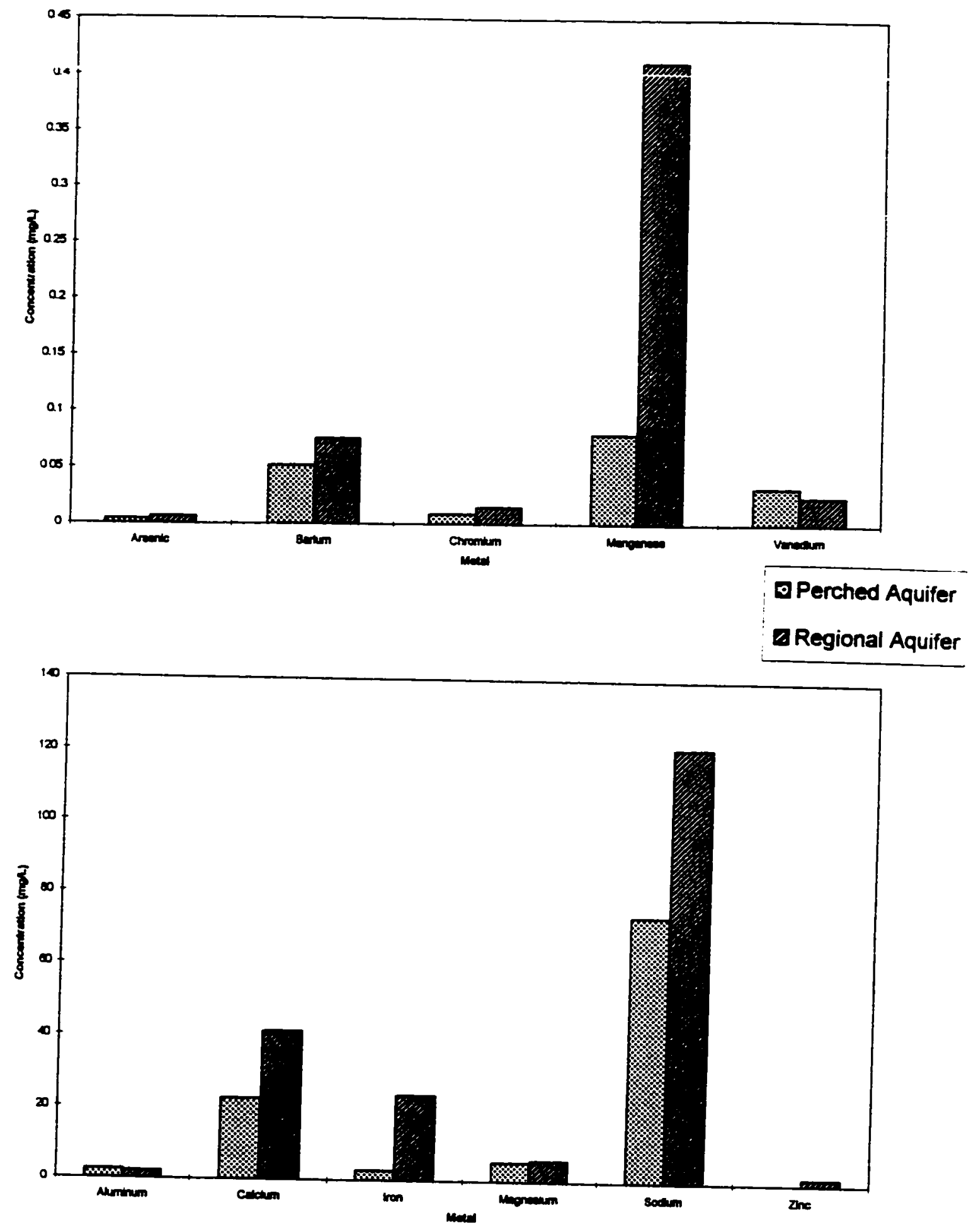

Figure 26. Comparison of average metals concentrations in the perched and regional aquifers. 


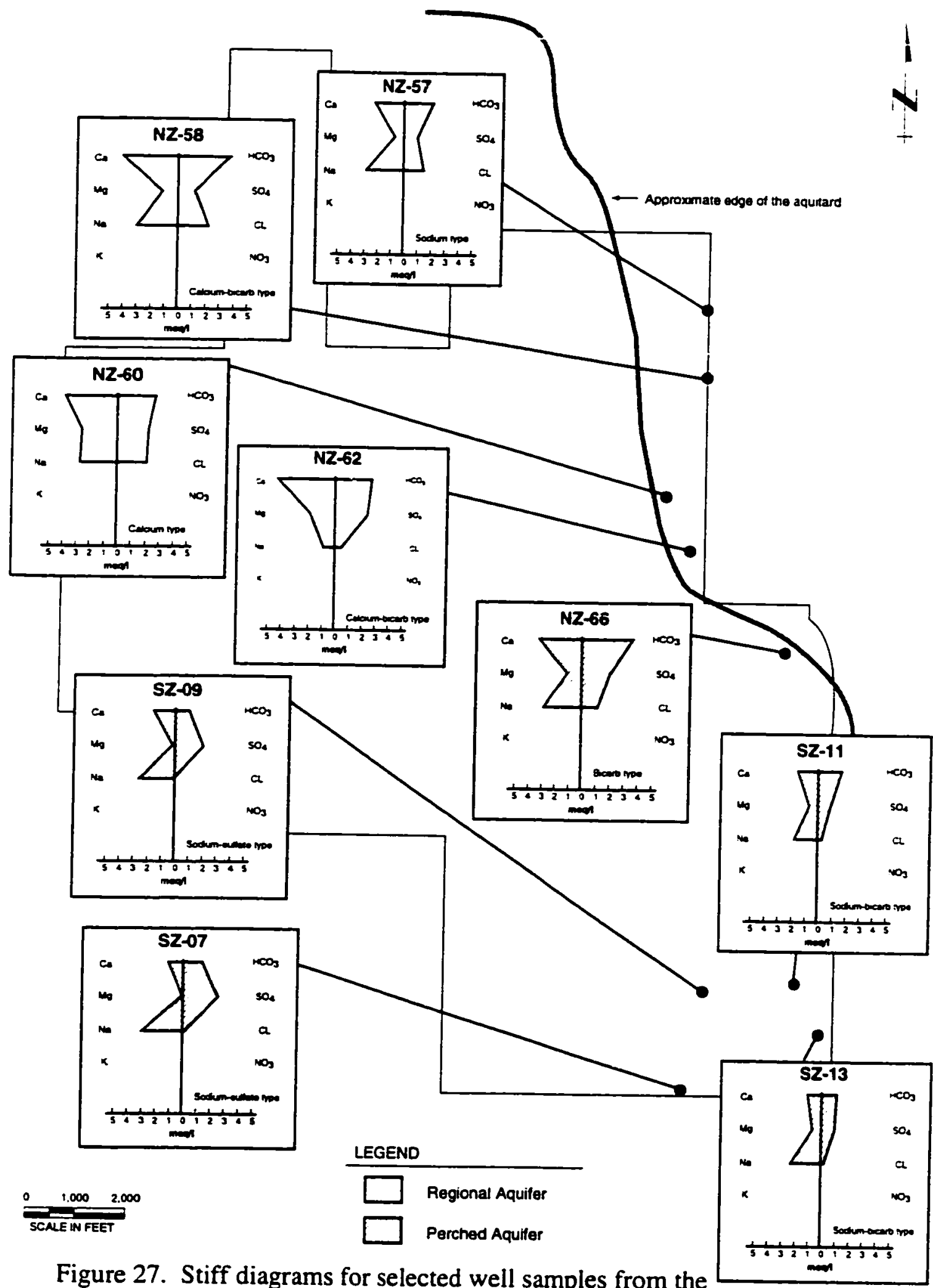
regional and perched aquifers. 


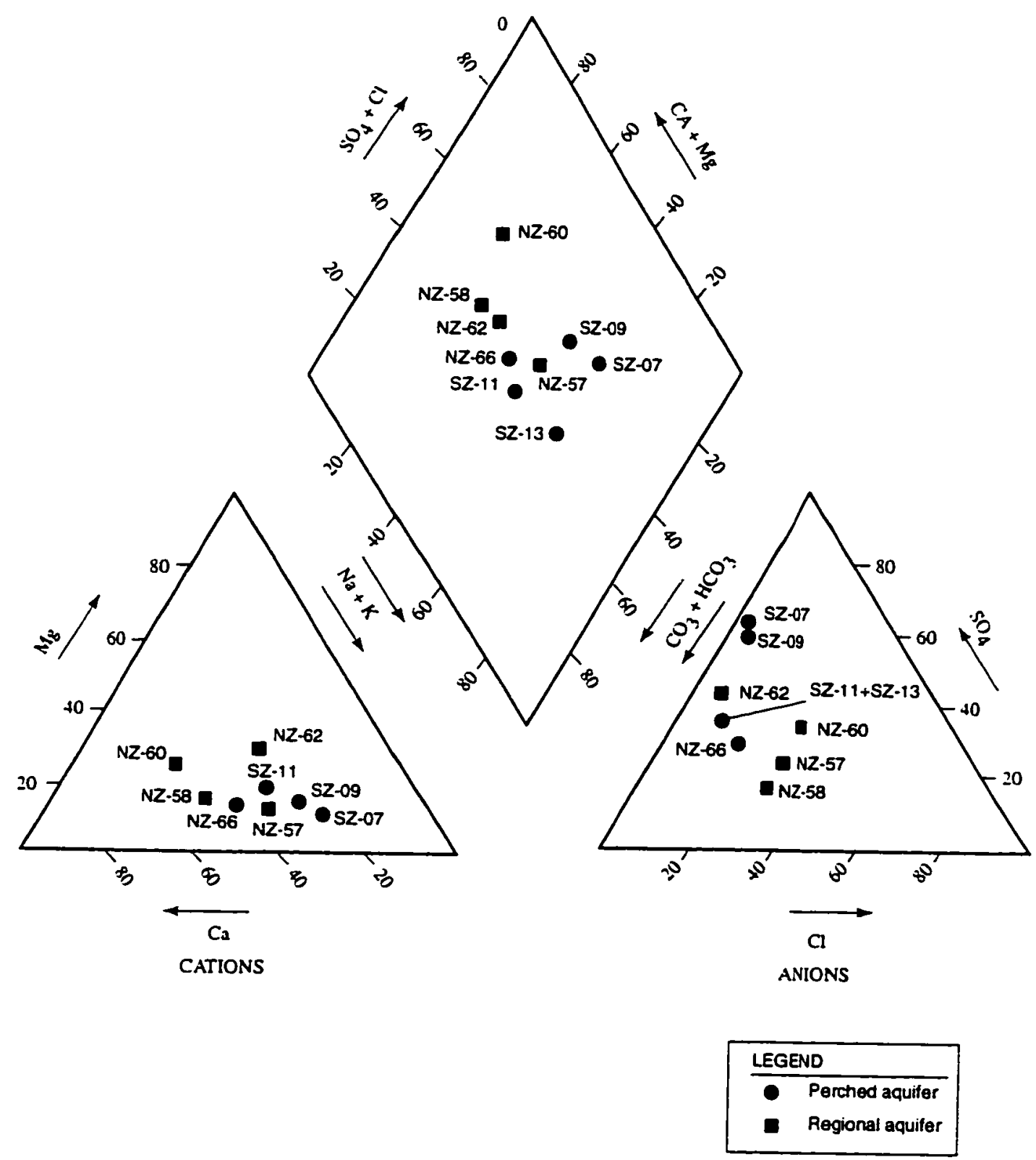

Figure 28. Piper diagram for selected well samples from the perched and regional aquifers. Chemical analyses of water represented as percentages of total equivalents per liter. 
northeastern portion of the base is a calcium-bicarbonate to sodium-bicarbonate-type.

The perched aquifer in the southeastern portion of the base is predominantly a sodium-sulfate to sodium-bicarbonate-type. Chloride is more prevalent in the regional aquifer than in the perched aquifer.

\section{Field Work}

Surficial exposures of significant lithologic units and other geologic features at GAFB and the immediately surrounding area are displayed on Figure 29. Field mapping observations were used to construct this figure, which is refined from existing maps of the area.

The contact between the Upper and the Lower Alluvial Units was mapped based on the presence of volcanic clasts in the Lower Alluvial Unit. These clasts are easily identified as rounded purple and pink clasts, in addition to hard, subangular to subrounded, dark gray to black clasts. These volcanics are attributed to the Mesozoic Sidewinder group (B. Cox, 1996, oral communication). Other distinctive components of the Lower Alluvial Unit were identified in both soil cores and in outcrop, and include brown to red chert and epidote. The distinctive purple, pink, and dark colored volcanics were observed in the alluvial fan beneath the mountains east of GAFB. This fan is, therefore, mapped as the Lower Alluvial Unit (Fig. 29). 


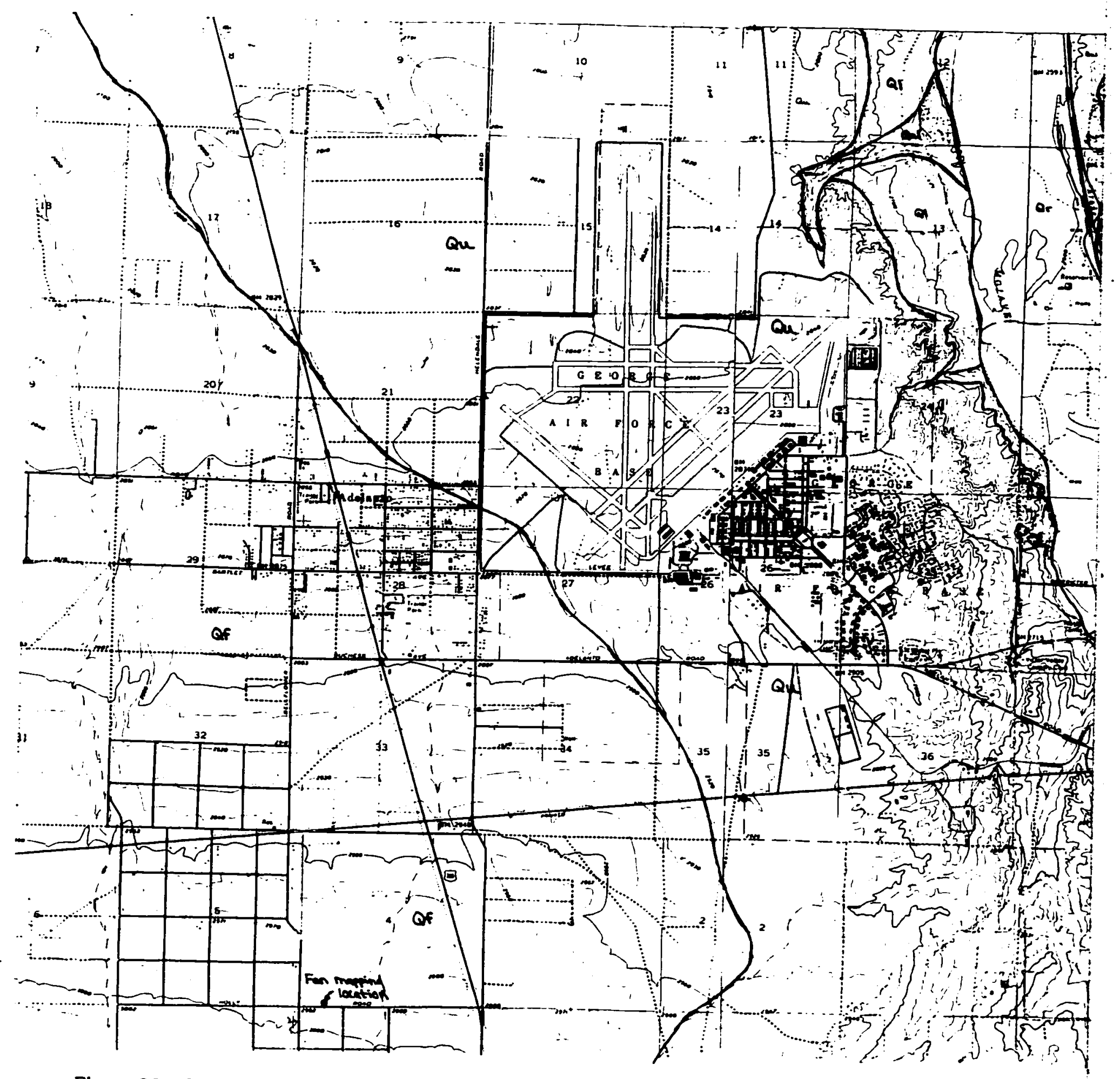

Figure 29. Geologic map of the George Air Force Base vicinity (basemaps USGS Victorville and Adelanto $7.5 \mathrm{~min}$. quadrangles, 1981). Quaternary units mapped by the author; bedrock units are modified from Dibblee (1960). 


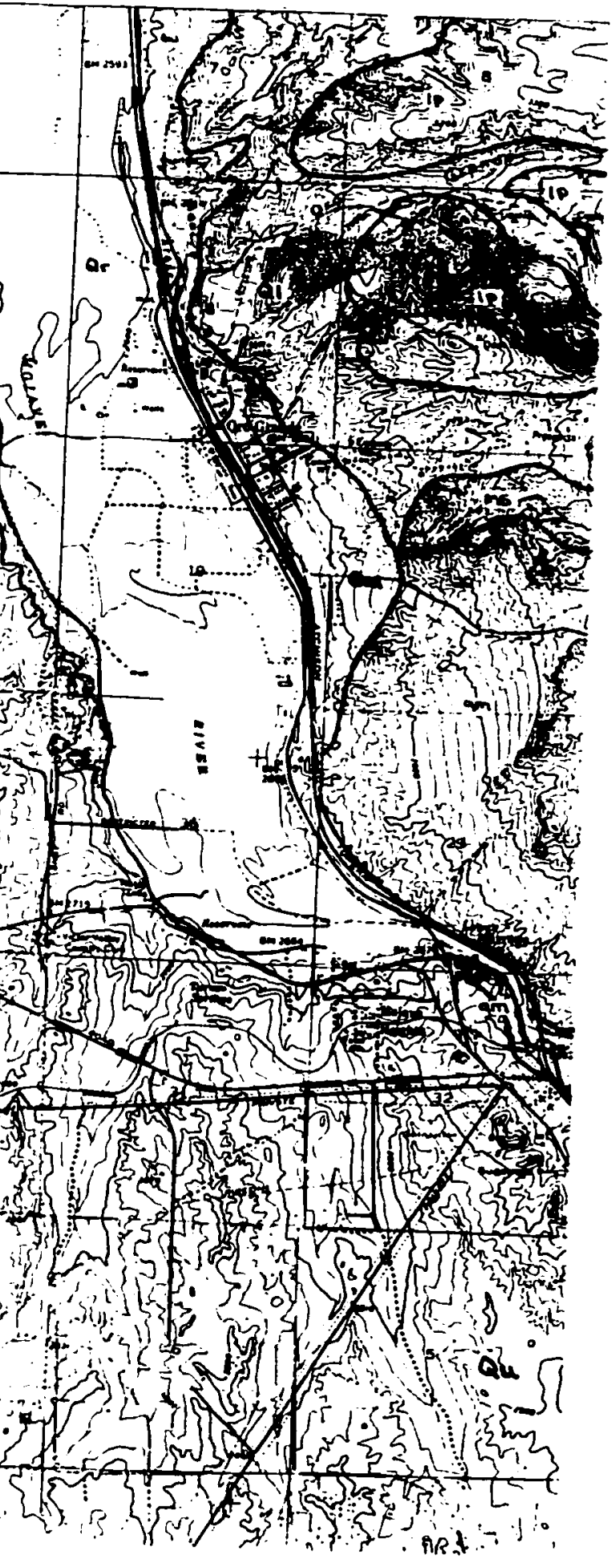

\section{LEGEND}

Qal Quaternary Alluvium (undifferentiated)

Qf Quaternary Victorville Fan

Qu Quaternary Upper Alluvial Unit

Q1 Quaternary Lower Alluvial Unit

Ip Latitic porphyry (Mesozoic?)

Porphynitic volcanic and motavolcanic racks of composition within the range of katite, quartz latite, dacite, and andesite; may contein Triassic (?) Sidewinder volcanics (Dibbleo, 1960).

qm Quartz monzonite (Mesozoic?)

ms Metasedimentary rocks (Paleozoic?)

Oro Grande motasedimentary rocks of marine origin. Includes finestone, dolomite, calc-silicato homfels, schist and argilite, and quartite (Dibbloo, 1960).

\section{QBO Trees}

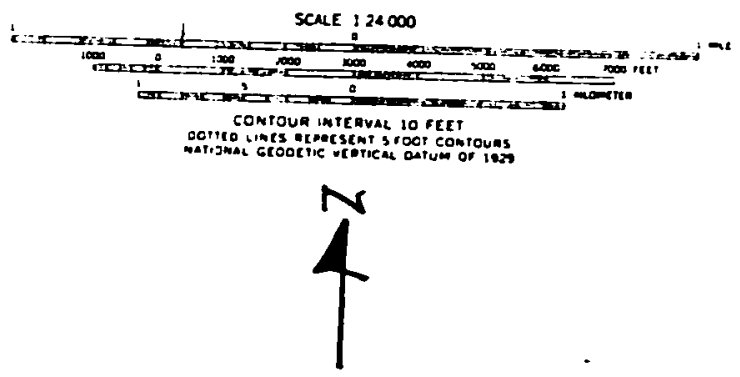


In addition to volcanic indicators, the contact between the Upper and Lower Alluvial Units is identifiable in the field as a distinct break in slope. This break occurs at an elevation of approximately 2,760 to 2,740 feet msl along the northeastern portion of GAFB, and drops to approximately 2,700 feet toward the south (Fig. 29). Above this break, the Upper Alluvial Unit forms steep bluffs characterized by tan to light gray finegrained units. The Lower Alluvial Unit forms gentler slopes (Fig. 3), which are locally covered by slope wash from the steeper portion of the overlying bluffs.

East of GAFB, a fine-grained unit was observed cropping out in the vicinity of the isolated stands of trees and Turner Springs at an elevation approximately 2,700 feet msl (Fig. 29). This fine-grained unit, and units like it, are believed to have created the springs and supported tree growth in the desert by sustaining seepage of perched water in surficial exposures.

The exposures at Tumer Springs and beneath the trees are tan to light gray sandy silt and silty sand and do not resemble the olive-brown laminated silt or brown clay of the aquitard. These units may be related to the shallow unit supporting the perched aquifer in the southeastern portion of GAFB. In RZ-01, this unit is encountered at approximately 2,660 feet msl. The elevation of the perched aquifer at the eastern edge of the base is approximately 2,720 feet msl, which is only slightly higher than the trees and springs to the east, possibly indicating that seepage from the perched aquifer sustains these features. 
Surficial deposits and shallow roadcuts were examined in the Victorville Fan approximately 2.5 miles southwest of GAFB along Holly Road (Fig. 29). Pebbles and small cobbles of a distinctive, dark-brown schist were observed throughout the exposure of the fan material. According to published documentation (Meisling, 1984; Bortungo and Spittler, 1986) and field observations by USGS personnel (B. Cox, 1996, oral communication), the clasts are from the Pelona Schist, a significant component of the San Bernardino Mountains and of the Victorville Fan. This schist was not observed in the shallow deposits beneath GAFB, possibly indicating that the Upper Alluvial Unit may not be part of the Victorville Fan.

\section{Results of X-Ray Diffractometric Testing}

Table I summarizes information regarding the samples tested using XRD techniques. Graphs of the XRD patterns for all tested samples are presented in Appendix B. Figure 30 presents the graphs of the XRD results for the unwetted, crushed samples. This figure is presented to provide a qualitative comparison of the general XRD patterns generated by aquitard samples basewide. Table 7 summarizes the mineral composition of clays and lists other minerals detected using XRD testing.

Qualitatively, the XRD patterns created by the crushed samples appear very similar basewide, displaying dominant peaks in the range of 10-14 $\AA$ (montmorillonite and illite) and near $3 \AA$ (quartz and feldspar). Other peaks identified include calcite ( 3.0 and 


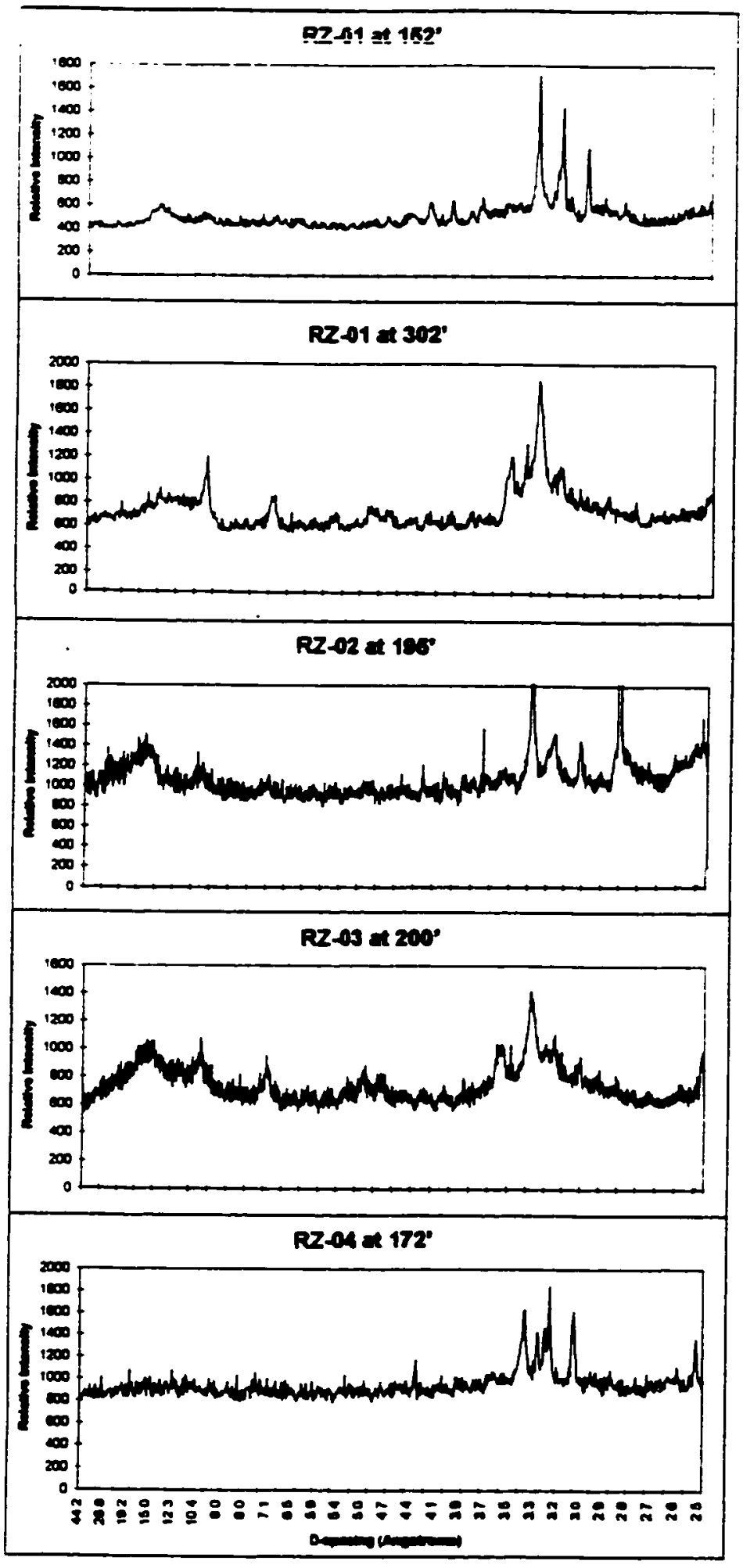

Figure 30. XRD patterns for unwetted, crushed samples. 


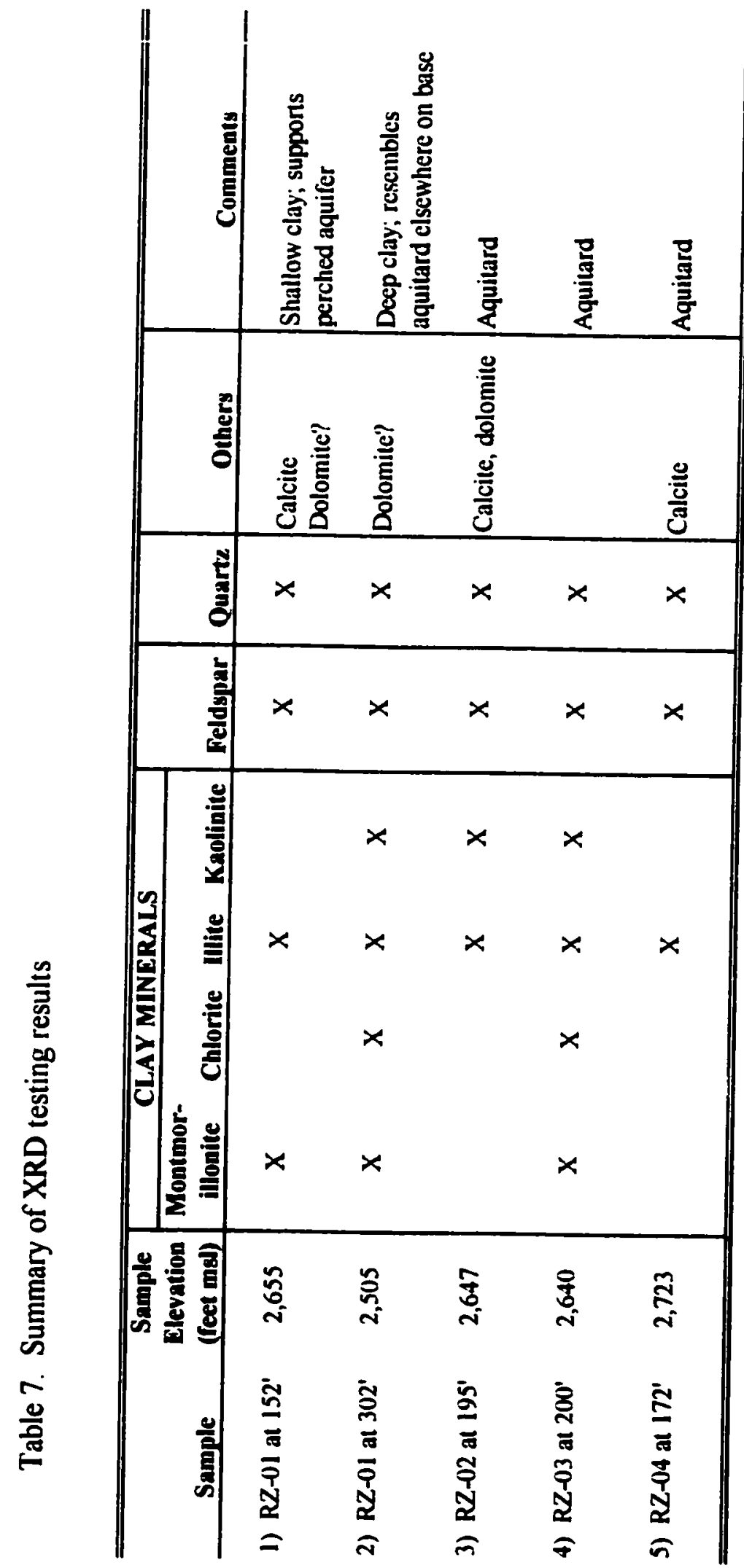


$3.9 \AA)$ in RZ-01 at 152 feet, RZ-02, and RZ-04; and dolomite (2.89 and $3.7 \AA)$ in RZ-02 and possibly in the two samples from RZ-0I.

The sample from RZ-01 at 302 feet displays elevated peaks in the $10 \AA$ range, and in the 2.5 to $2.6 \AA$ range.. The $10 \AA$ range peak is interpreted to be from the predominance of clays in the sample with little interference from other constituents.

Heating and glycolation revealed that three samples contain montmorillonite (RZ01 at 152 and 302 feet, and RZ-03), two contain chlorite (RZ-01 at 302 feet and RZ-03), three contain kaolinite (RZ-01 at 302 feet, RZ-02, and RZ-03), and all samples contain illite. Quartz and feldspar are also present in all samples.

Considering the predominantly siliceous source areas and abundance of feldspar in the vicinity, the presence of montmorillonite and kaolinite in the tested samples is expected. Similarly, the presence of illite is interpreted to reflect a siliceous source. Although chlorite is commonly associated with metamorphic rocks, it is also a common constituent of igneous rocks and is likely attributable to local igneous sources.

$\mathrm{XRD}$ testing did not reveal peaks in the ranges of common evaporites such as halite, gypsum, thenardite, or trona, all of which are reportedly present in the soils of the Victorville area (Izbicki et al., 1994). Furthermore, there were no peaks in the ranges of authigenic silicate minerals such as analcime, chabazite, or clinoptilolite, which are common in desert playas. Those minerals have been identified in Lake Tecopa and the Barstow Formation in the eastern Mojave Desert, where saline lake conditions facilitated 
their formation from silicate minerals and tuffs (Sheppard and Gude, 1968). XRD testing is not useful in determining whether clays are detrital or authigenic.

\section{Results of Thin Section Point Counting}

Table 2 summarizes information regarding the samples used for point counting. Table 8 and Appendix $\mathrm{C}$ summarize the results of the point counting and the percentages of various categories identified. Figure 31 displays the point counting results plotted on triangular diagrams, one with quartz plus feldspar, plutonic rock fragments (PRF), and volcanic rock fragments (VRF) at the apices; and the other with quartz, feldspar, and total rock fragments at the apices. For the classification depicted in Figure 31, chert was counted as a rock fragment according to Folk's (1980) classification scheme. Figure 32 graphically compares sand above and below the aquitard.

Figure 31 shows that all of the sands tested fall within relatively similar areas on the diagrams. Significantly different population compositions between sands above and below the aquitard are not evident. Sample 9 (RZ-04 at 163 feet) plots farthest away from the other samples, predominantly due to its relatively high quartz content. This sample is further discussed below.

The majority of rock fragments identified in the Upper and Lower Alluvial Units are plutonic rocks, ranging from approximately 9 to 39 percent. Chert is the second most abundant rock fragment, and is present in quantities between 0 and 11 percent. Volcanics 


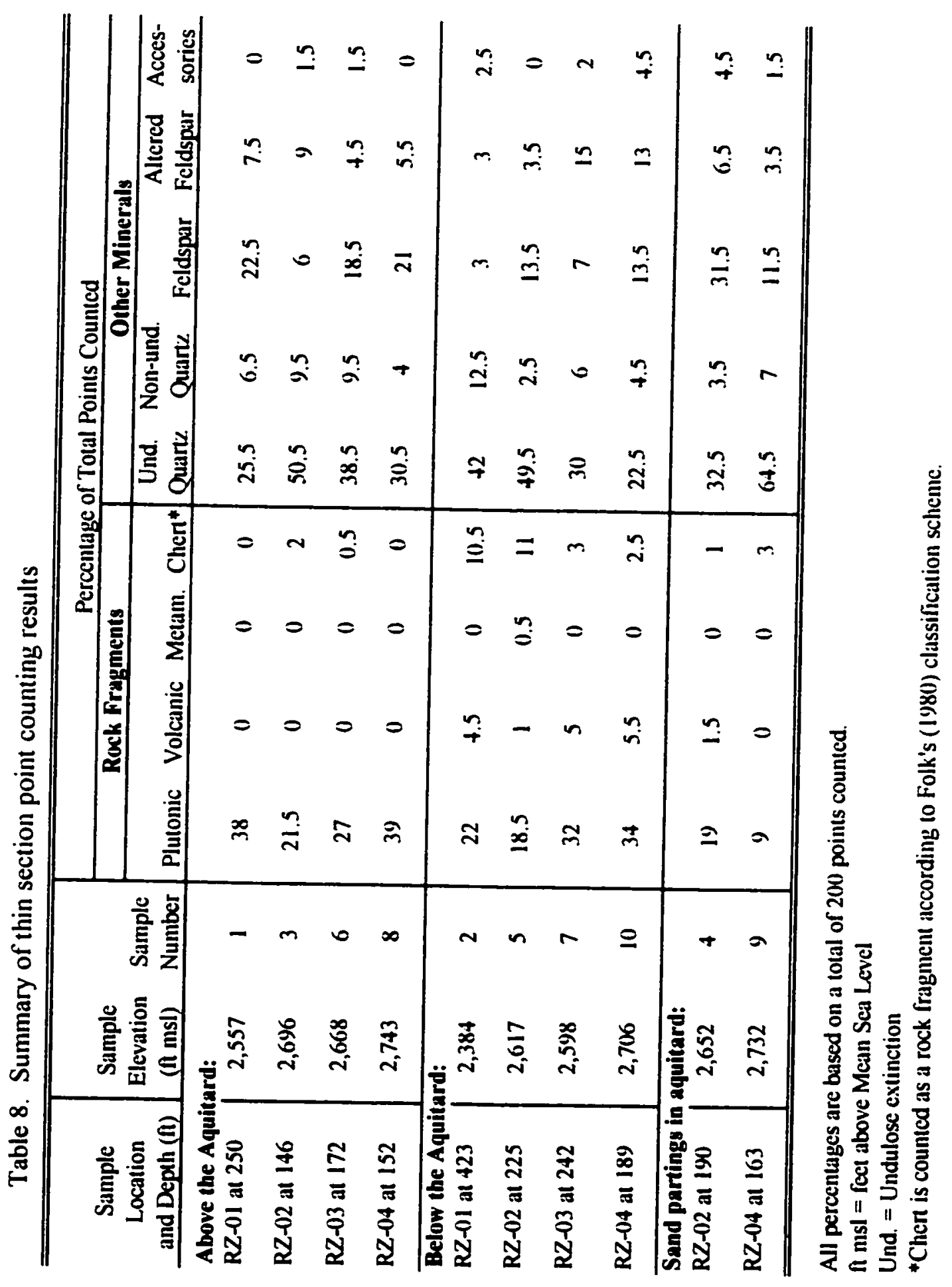



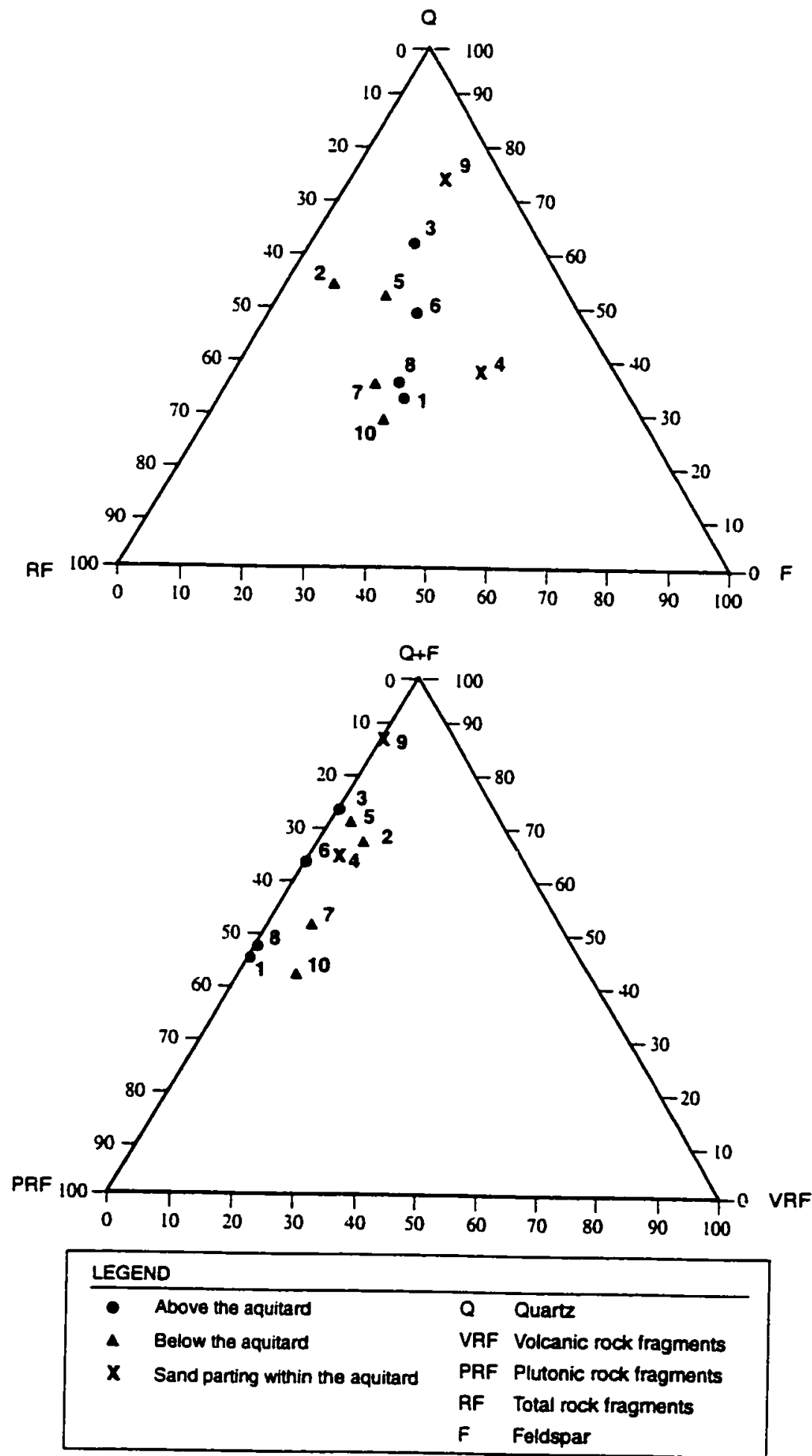

Figure 31. Triangular plots of thin section point counting results. 


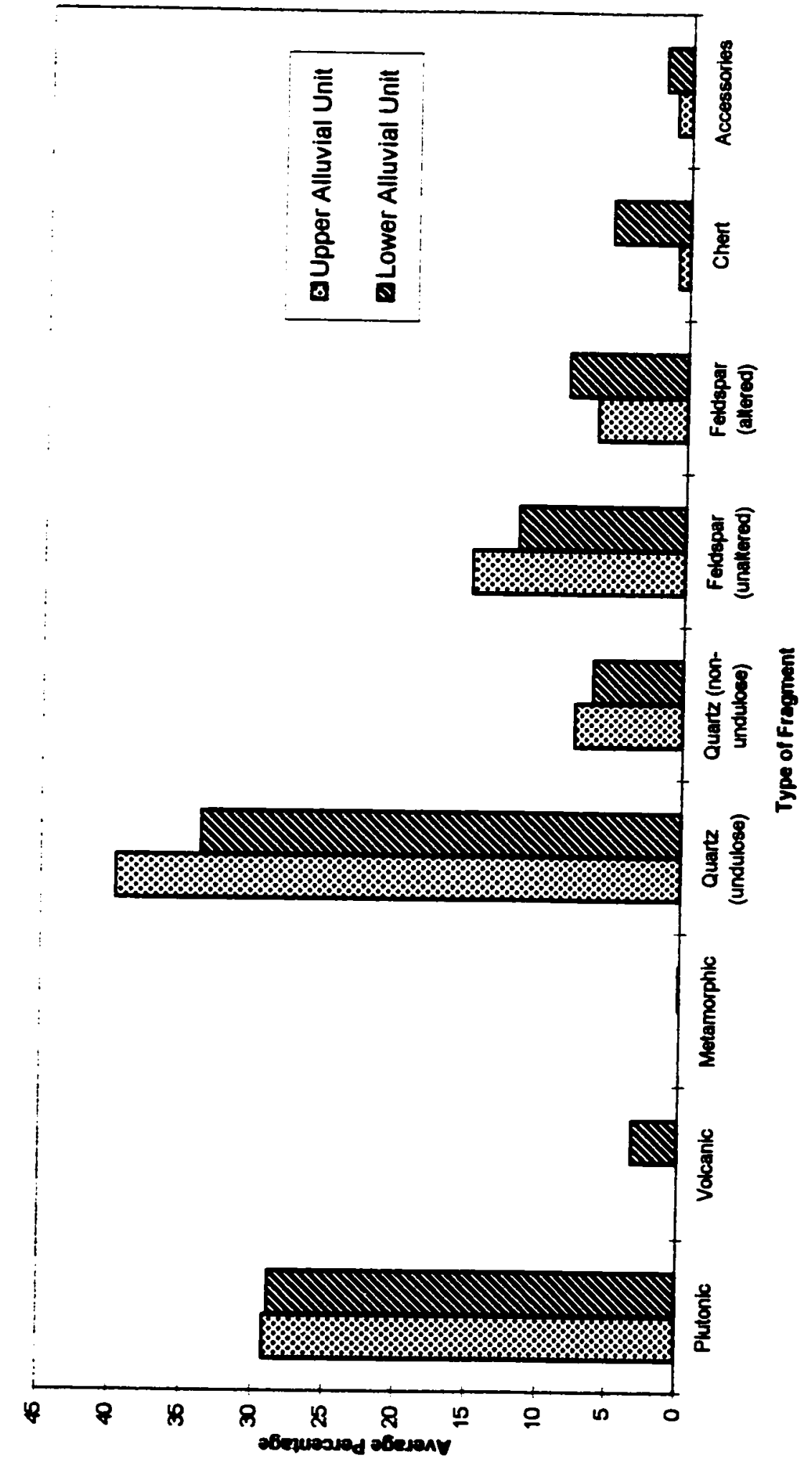

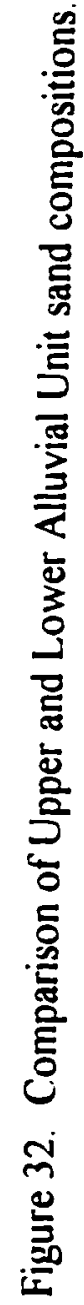


are the third most abundant rock fragments, ranging from 0 to 5.5 percent.

Fragments composed entirely of quartz are present in both single- and multicrystalline grains, often exhibiting undulose or semi-undulose extinction (Fig. 33).

Feldspar grains typically exhibit albite twinning and range in appearance from fresh to partially or significantly altered (Fig. 34).

The plutonic grains typically exhibit a hypidiomorphic-granular (subhedral) texture (Fig. 35). The primary constituents of plutonic grains are quartz and feldspar, with rare accessory minerals exhibiting high birefringence (Fig. 35). Volcanic grains contain euhedral feldspar laths enclosed in a cryptocrystalline matrix. Volcanic grains include deep red vitreous components within the matrix material (Fig. 36).

Of all grains counted, only one was characterized as metamorphic (sample RZ-02 at 225 feet). This grain may actually be of metavolcanic origin, displaying crystal alignment from a flow texture (Fig. 37).

Accessory minerals, though a minor part of the grain population, primarily include minor dolomite (Fig. 38) and rare grains exhibiting high birefringence (Fig. 39). These highly birefringent grains are likely pyroxenes or epidote.

Of the rock fragments counted, plutonics are predominant in sands both above and below the aquitard, and are present in similar amounts in both units (approximately 29 percent). Chert is significantly more abundant below the aquitard than above it. Volcanics are present only in sediment below the aquitard, and in one sample (Sample 4) from a sand parting within the aquitard. 


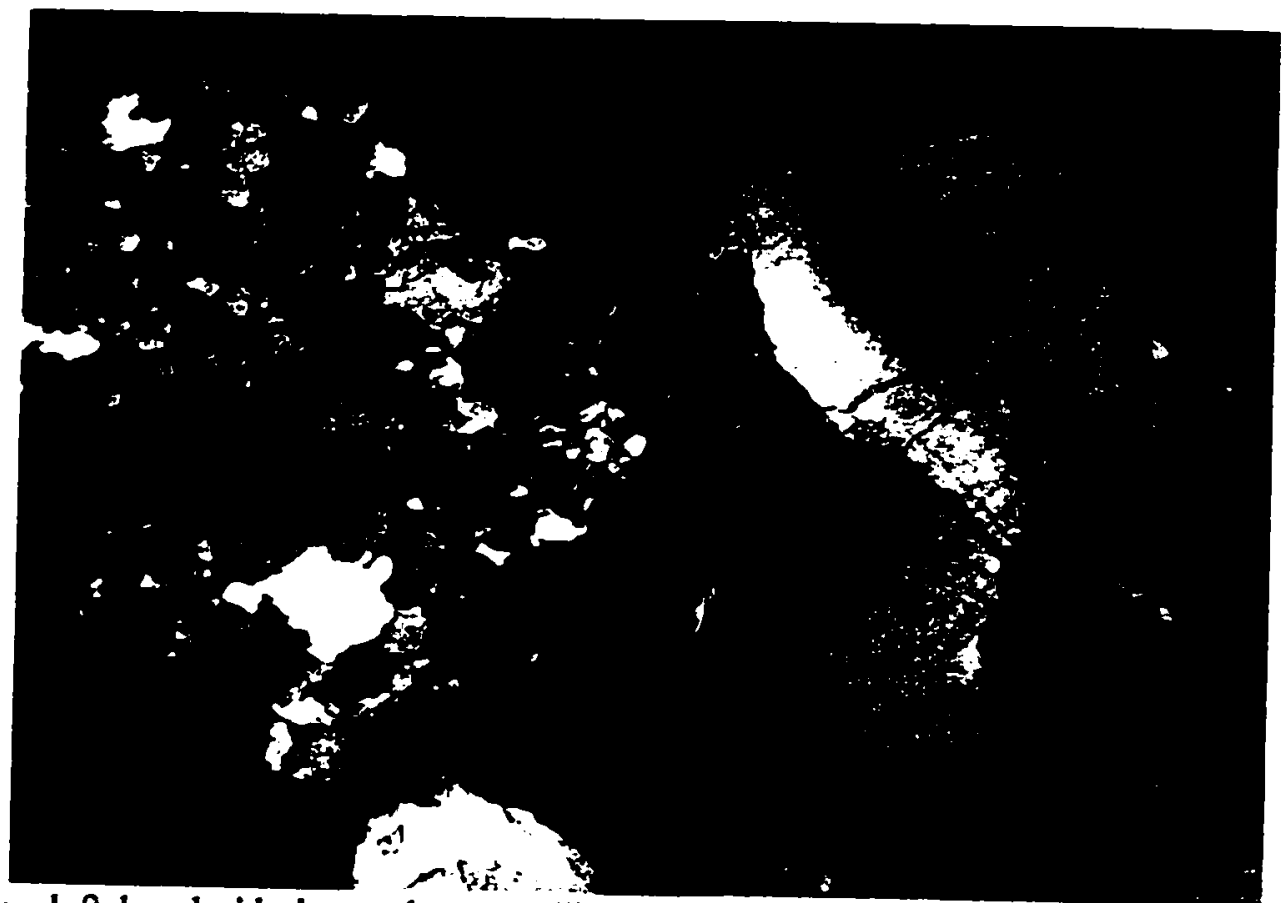

(a) Grain on left-hand-side is a poly-crystalline quartz. Grain on right is single quartz grain.

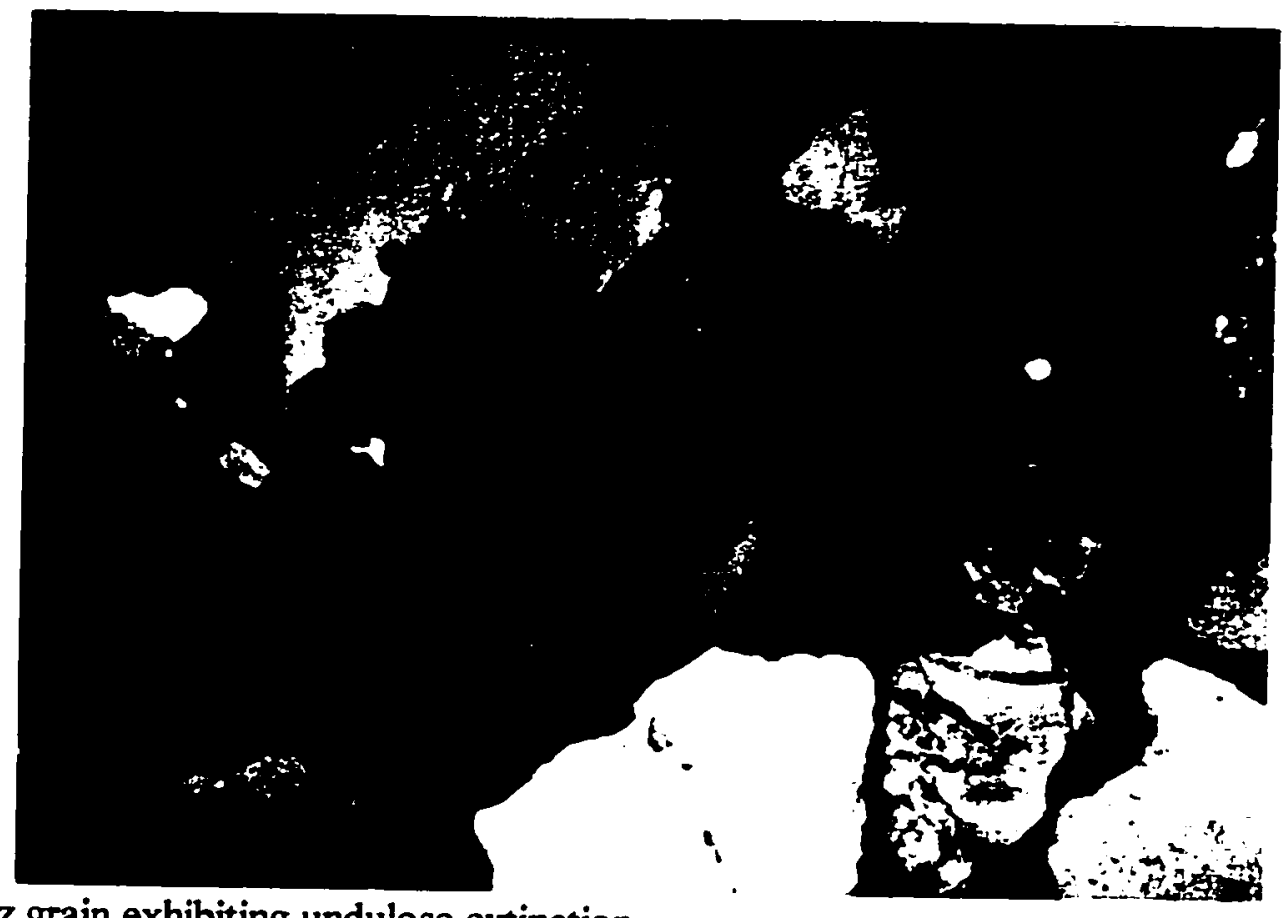

(b) Quartz grain exhibiting undulose extinction.

Figure 33. Thin sections of single- and poly-crystalline quartz grains (a) and undulose extinction in quartz (b) in Sample 4. Width of field of view is $3 \mathrm{~mm}$. 

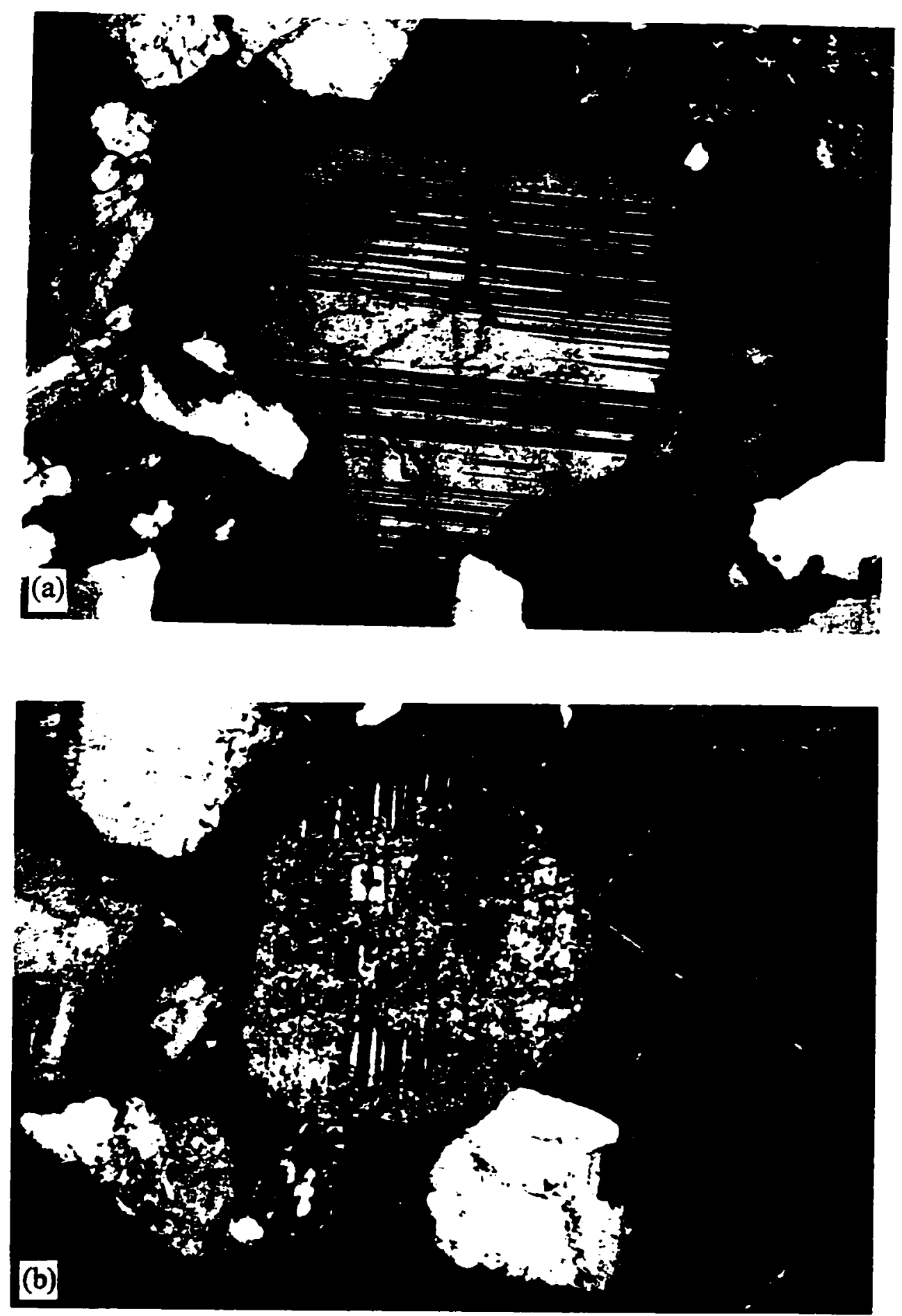

Figure 34. Thin section of unaltered (a) and altered (b) feldspar grains in Sample 2. Width of field of view is $3 \mathrm{~mm}$. 

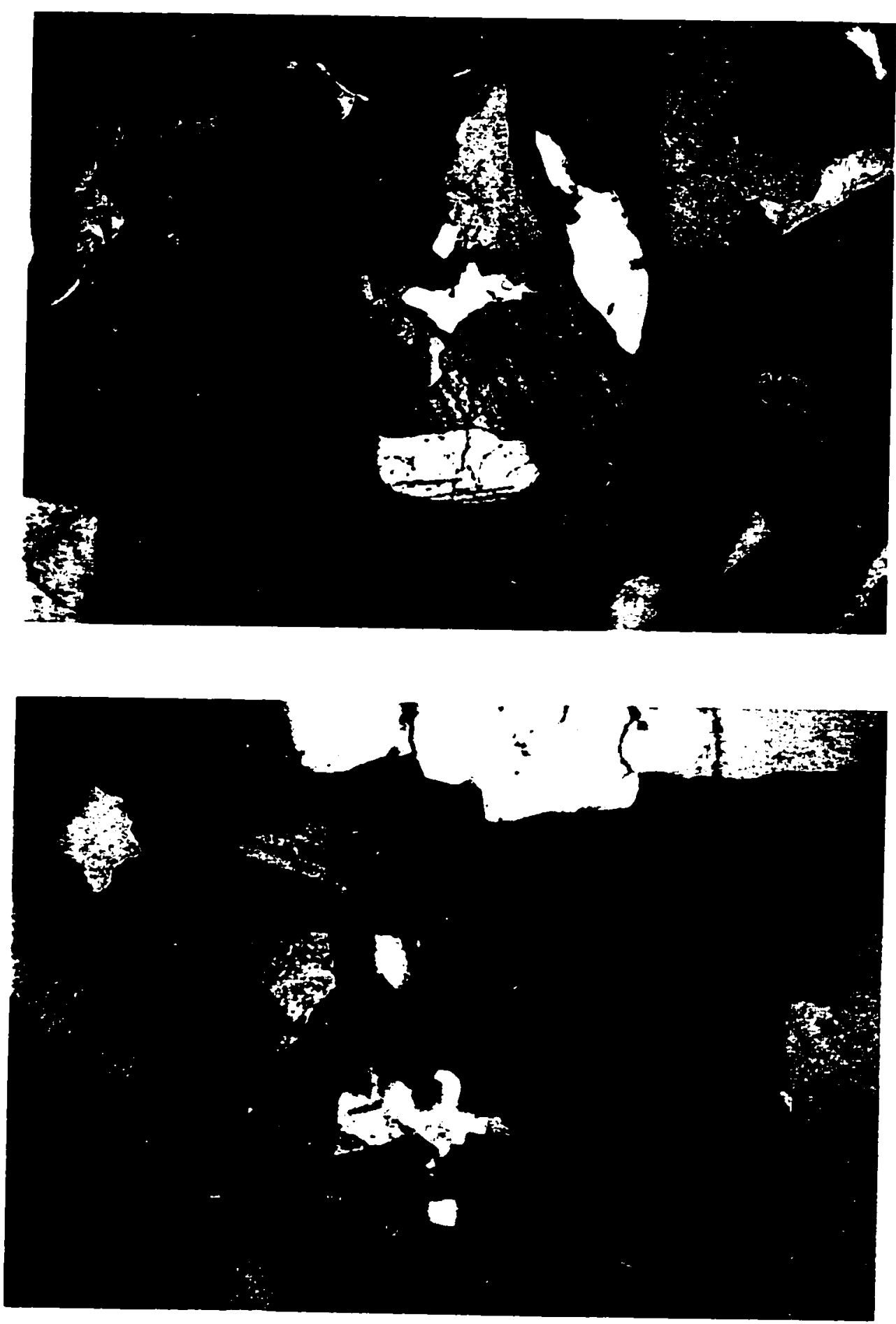
$3 \mathrm{~mm}$.

Figure 35. Thin sections of plutonic grains in Sample 3. Width of field of view is 


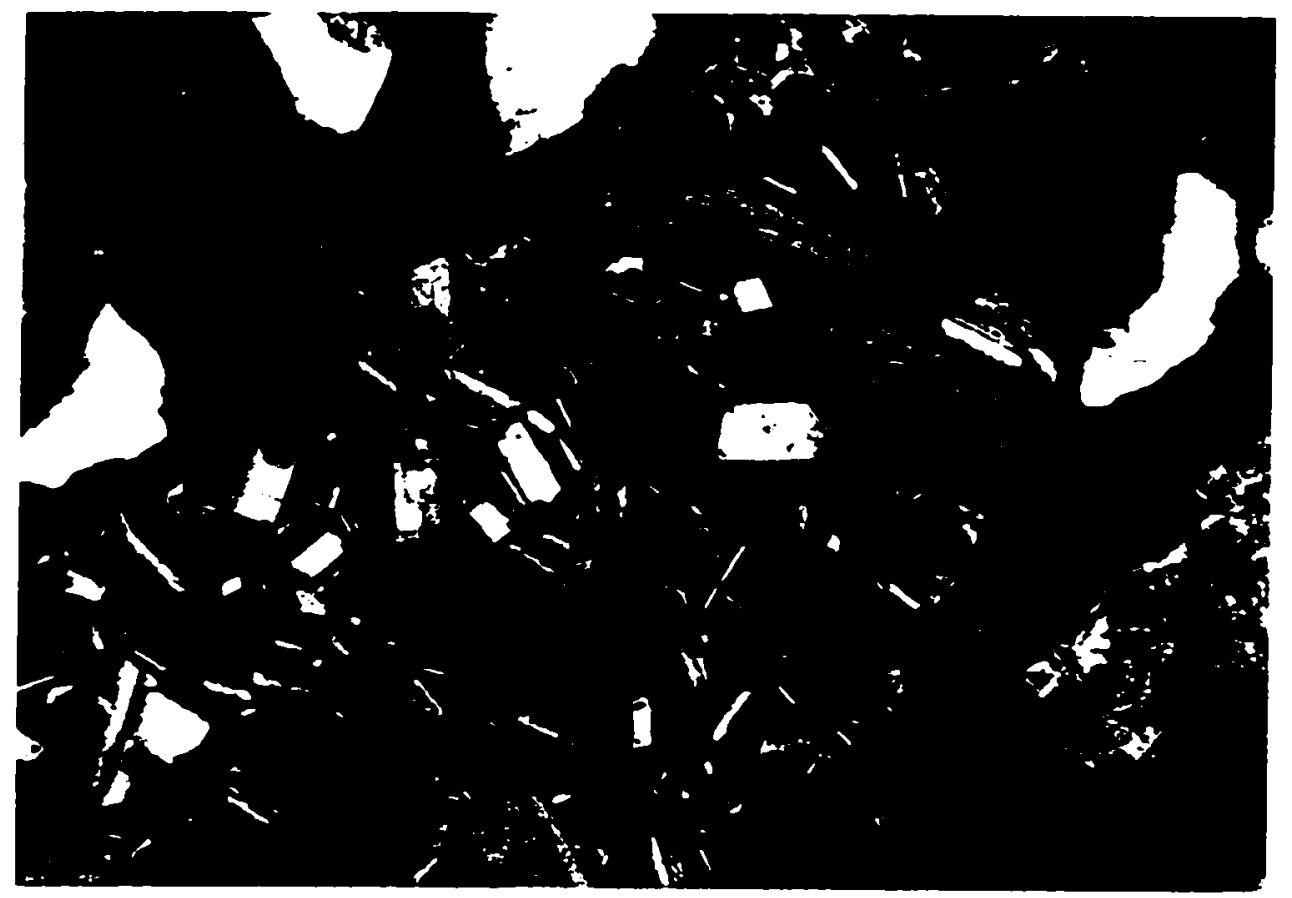

Figure 36. Thin Section of volcanic clast in Lower Alluvial Unit in Sample 7. Light-colored inclusions are twinned feldspar crystals. Width of field of view is $3 \mathrm{~mm}$. 


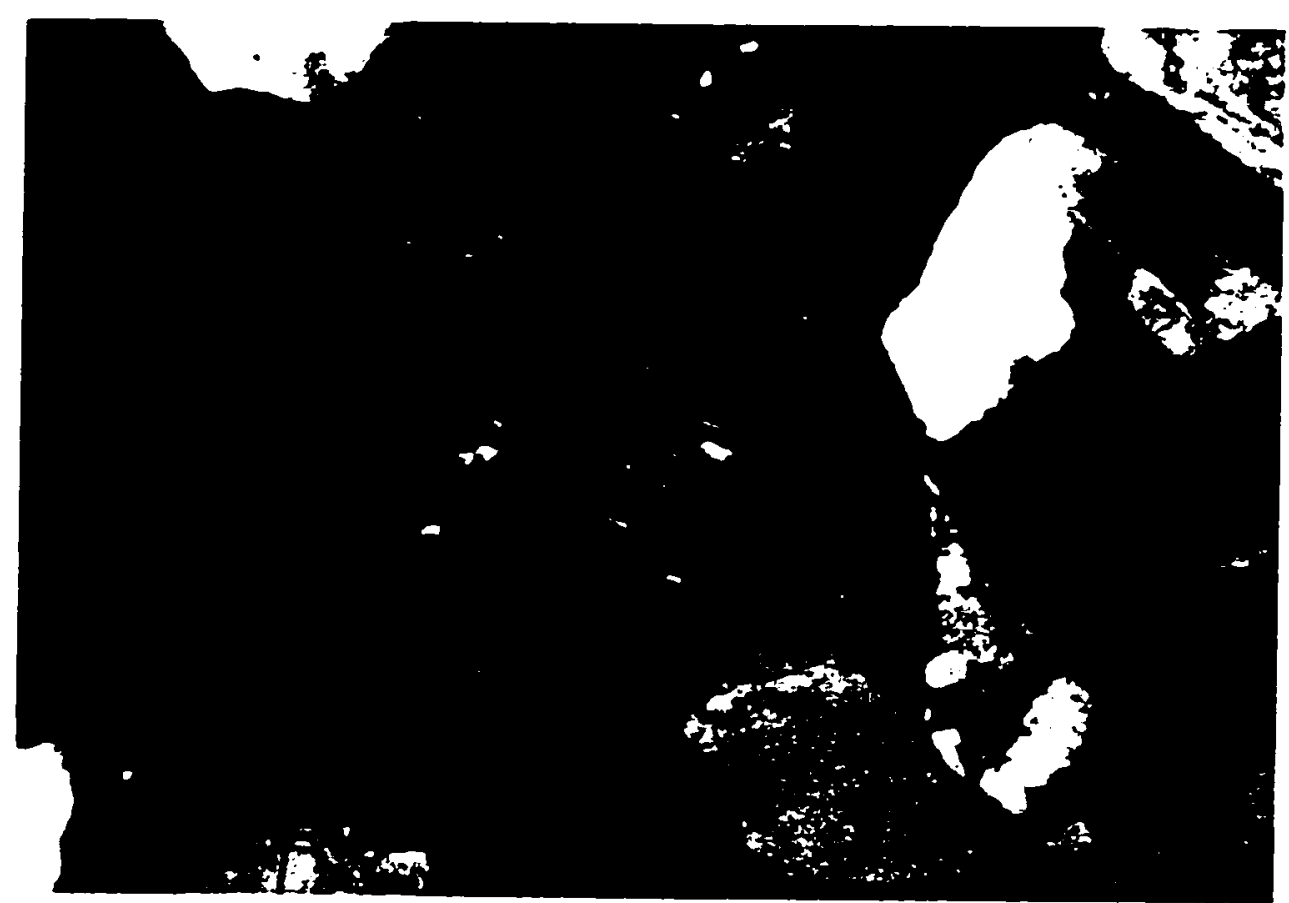

Figure 37. Thin section of metamorphic or metavolcanic grain in Sample 2. Width of field of view is $3 \mathrm{~mm}$. 

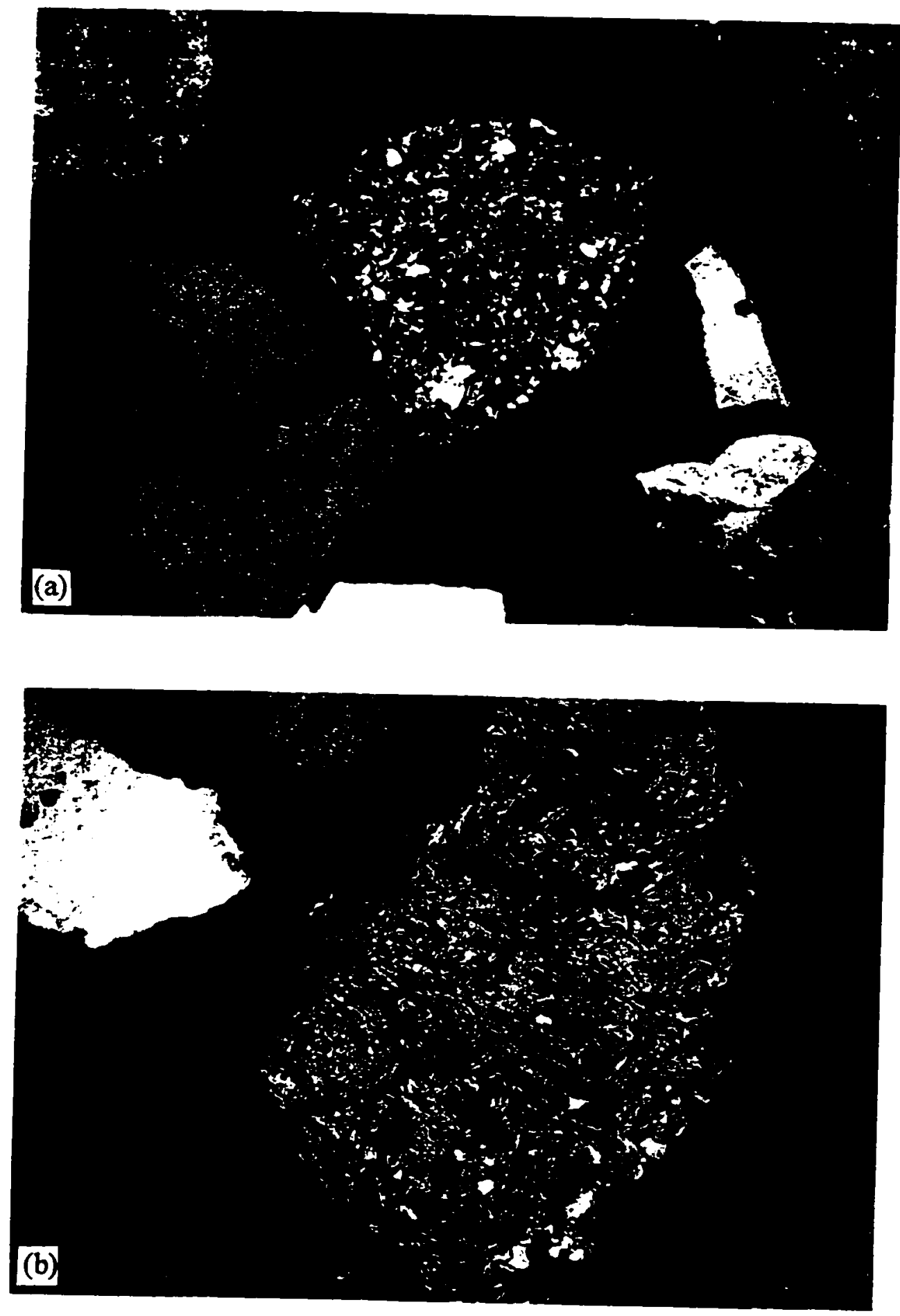

Figure 38. Thin section of chert (a) and dolomite (b) grains in Sample 10. Width of field of view is $3 \mathrm{~mm}$. 


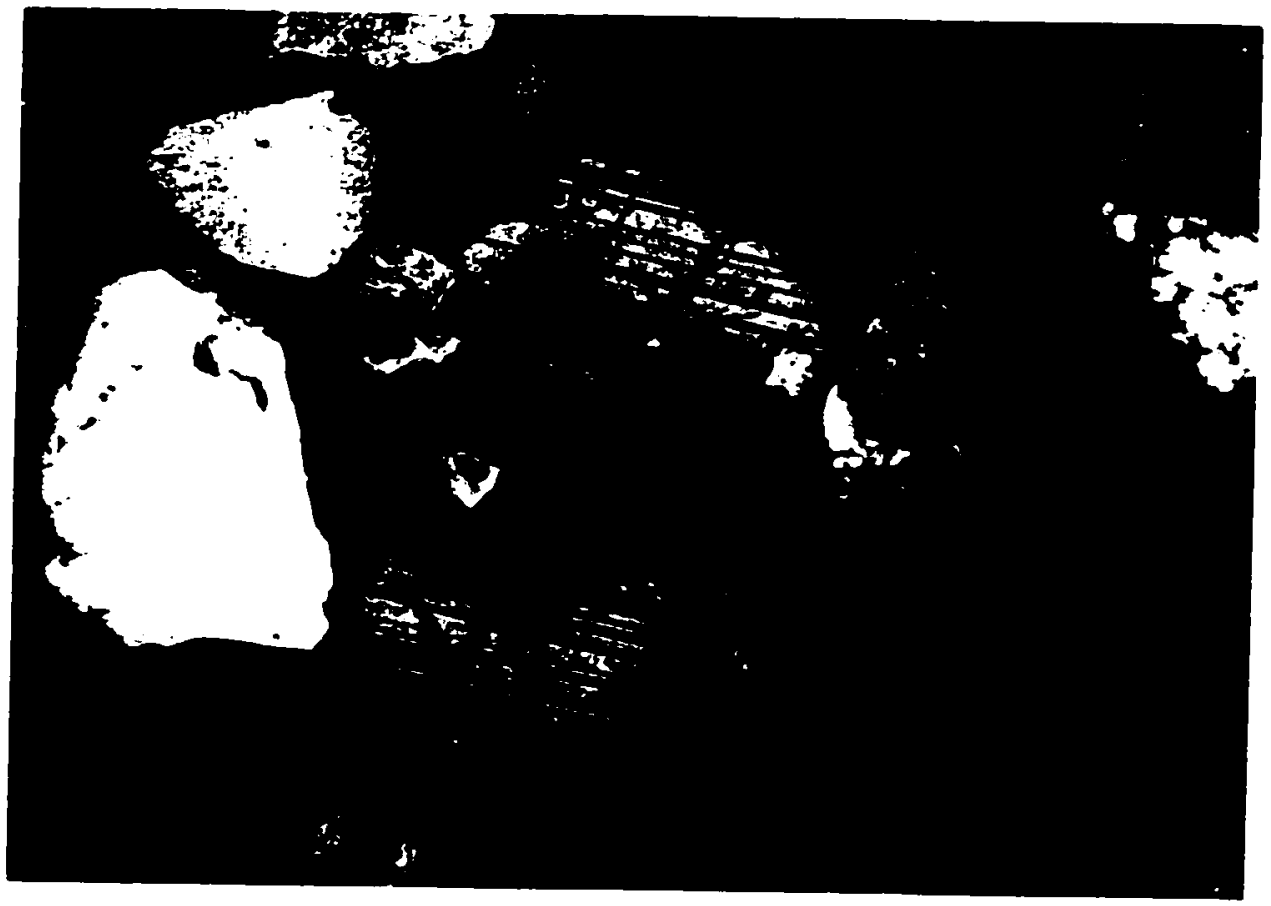

Figure 39. Thin section of accessory mineral with high birefringence in Sample 10. Striated grain in middle of figure is feldspar. Width of field of view is $3 \mathrm{~mm}$. 
Of the single mineral fragments counted, quartz (both single- and poly-crystalline fragments) is predominant, with the majority of fragments displaying undulose or semiundulose extinction. The predominance of quartz is expected, as the study area is dominated by granitic source areas and quartzite is common in both the San Bernardino and San Gabriel Mountains (B. Cox, oral communication, 1996), and in the mountains east of GAFB. Feldspar is the second most common mineral, with chert and accessory minerals least common.

Quartz and unaltered feldspar are slightly more predominant in sand above the aquitard than below. Altered feldspar is more common below the aquitard. Accessories, primarily composed of dolomite, are also more abundant below the aquitard.

The two sand samples from within the aquitard differ notably in composition. While both samples consist predominantly of quartz, Sample 4 (RZ-02 at 190 feet; elevation 2,656 feet msl) contains 36 percent quartz, 19 percent plutonic rock fragments and 1.5 percent volcanics. Sample 9 (RZ-04 at 163 feet; 2,732 feet msl) contains nearly 72 percent quartz, 9 percent plutonic rock fragments and no volcanics. This sample plots furthest from the other samples on the triangular plots (Fig. 31) due to its relatively high quartz content.

An interesting finding is the absence of volcanics in Sample 1 (RZ-01 at 250 feet; elevation 2,557 feet msl). This sample is below the shallow, fine-grained unit in RZ-01 but above the unit resembling the true aquitard. Volcanics would be expected beneath the 
shallow unit in RZ-01 if that unit were the aquitard or a related facies. Volcanics were found in Sample 2 (RZ-01 at 423 feet), which is below the unit resembling the aquitard. 


\section{DISCUSSION}

The existing 3-layer, 2-aquifer conceptual hydrogeologic model of GAFB developed by Montgomery Watson (1995) was essentially supported by this investigation. The suspected difference between the Upper and Lower Units, based on the presence of volcanics in the Lower Alluvial Unit, was also supported.

The primary findings of this investigation that differ from the existing model are the interpretations that (1) the Upper Alluvial Unit may not be part of the Victorville Fan, as stated in the existing model; and (2) the aquitard may not be one continuous unit basewide, but, rather, it may be offset in the southeastern portion of the base. The suspicion that the Upper Alluvial Unit may not be part of the Victorville Fan is supported primarily by the apparent absence of Pelona Schist in the shallow soils beneath GAFB and by the absence of metamorphic rock fragments in the sand samples.

\section{Extent of the Aquitard and its Configuration in the Southeastern Portion of GAFB}

Drillers logs for production wells in the region surrounding GAFB suggest that the aquitard extends roughly 1 mile north, west, and south of the base. This observation is supported by the appearance of thick "blue" and "green" clay layers close in elevation to the aquitard on GAFB (Figs. 16 through 18). Indirect evidence of the aquitard is based on the presence of the perched aquifer noted on the logs. The interpreted extent of the 
aquitard seams reasonable based on the sizes of Pleistocene lakes studied by Wells (1989) and Wells et al. (1990, 1994).

According to the physical appearance of the aquitard in soil cores, the aquitard in the southeastern portion of GAFB near RZ-01 appears to be significantly deeper than elsewhere. It is also thicker - approximately 94 feet versus 25 to 38 feet elsewhere. In addition, the shallow fine-grained unit in RZ-01 thought to be the aquitard in the existing model does not appear to be underlain by volcanics like the aquitard is beneath the rest of the base. This conclusion is supported by the RZ- 01 soil core and by thin section point counting results.

The explanation for the apparently unique conditions in the southeast portion of the base is not clear. One potential interpretation is that the shallow unit is a transitional facies such as a deltaic or shoreline deposit and, therefore, does not resemble the aquitard observed elsewhere because of its different depositional environment.

Another potential explanation could be that the shallower fine-grained unit is an unrelated unit that is present at an elevation coincidentally similar to that of the aquitard observed elsewhere. The deeper unit in RZ-01 may be the true aquitard, offset downward relative to sediments to the north by folding, faulting, or a combination of both.

The USGS (B. Cox, 1996, oral communication) cites potential evidence of a local east-west-trending fault in the vicinity of the Victorville Country Club on Turner Springs Road at the southwesternmost corner of Section 30 (Fig. 29). If this fault extended 
westward, it could offset the aquitard in the southeast portions of the base. Considering the abundance of local faults in the Mojave Desert, this does not appear to be an unrealistic scenario. Surficial evidence of the suspected fault was not observed by the author on GAFB, and the fault does not appear on known published maps of the area. The lateral extent of a potential fault or faults in this area is unknown.

If faulting created the conditions observed in the southeast portion of GAFB, movement likely began during or shortly after the deposition of the aquitard, as the aquitard appears to be present on both sides of the offset zone. The fact that the aquitard in the southeastern portion of the base is significantly thicker than elsewhere may indicate that downdropping created conditions that dammed drainage coming into the area from the south. This may have led to the formation of an upstream lake where the rate of sedimentation kept pace with displacement.

A late Pleistocene lacustrine sedimentation rate of about 1 meter ( 3.3 feet) per 1,000 years has been documented in the Mojave Basin (Wells et al., 1990). The aquitard in the southeast portion of the base is approximately 94 feet thick, which is roughly 60 feet ( 18 meters) thicker than elsewhere. The distance between the bottom of the unit on the north and south sides of the hypothetical fault indicates a total offset of roughiy 190 feet (58 meters). Based on the area's Pleistocene lacustrine sedimentation rates, it seems reasonable that the additional 60 feet of sediment could have accumulated on the south side of the fault. This accumulation would have occurred over a period of approximately 
18,000 years. A schematic figure depicting the above-described scenario for aquitard deposition and offset is presented in Figure 40.

The perched aquifer does not appear to be significantly impacted by the suspected fault; however, there are no monitoring wells in the vicinity of the suspected feature that can be used to examine whether there are indicators of hydraulic control by faulting. The perched aquifer on the south side of the fault appears to be supported by an approximately 20-foot section of fine-grained silt and clayey silt units logged in RZ-01 starting at a depth of 148.5 feet (elevation 2,658 feet msl). Considering the depositional history of the area, these fine-grained units are probably lacustrine or deltaic deposits.

Another potential scenario creating the unique conditions in the southeast portion of GAFB is that the aquitard is folded. According to the existing site model, the surficial expression of the aquitard beneath the GAFB appears to be irregular (Figs. 8 and 18). Considering the relatively uniform thickness of the unit, it is assumed that the aquitard has not been significantly eroded. Irregular surface elevations, therefore, may indicate that the aquitard was folded once it was deposited. The depth of the aquitard in borehole $6 \mathrm{~N} / 4 \mathrm{~W}$ 30 N06 (Fig. 16) northeast of RZ-01 is intermediate between the depth of the suspected aquitard in RZ-01 and the rest of the base, potentially indicating a gradual offset by folding rather than a more abrupt offset that would be expected from faulting.

The contact between the Upper and Lower Alluvial Units may also indicate folding. Brett Cox of the USGS has traced this contact from GAFB to approximately 6 


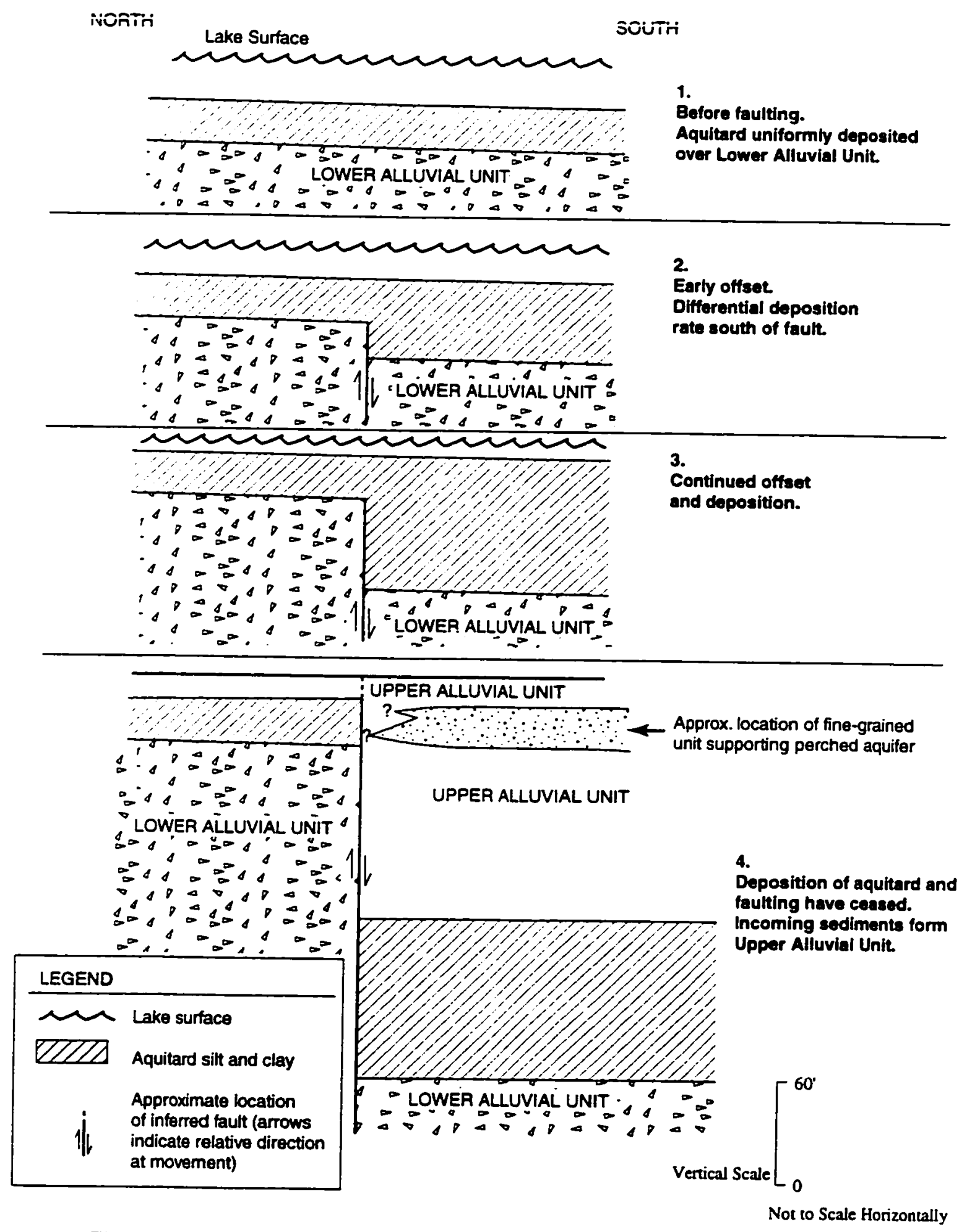

Figure 40. Schematic representation of deposition and faulting of the aquitard. This is one potential interpretation of the configuration of the aquitard in the southeastern portion of the George Air Force Base. 
miles north of GAFB (B. Cox, 1997, oral communication). According to Cox's observations, the elevation of the contact varies, which is interpreted to represent local potential folding.

\section{Quantifiable Differences in Water Quality and Hydrogeologic Characteristics}

The differences in average metal concentrations and general water quality parameters between the two aquifers may be attributable to lithologic differences in the materials forming the two aquifers. For example, the comparatively higher concentrations of manganese and iron in the regional groundwater may be due to the presence of volcanics in the Lower Alluvial Unit. The predominantly calcium-bicarbonate-type water in the regional aquifer may reflect the greater quantities of limestone and dolomite in the sediments forming this unit. The unnamed range east of GAFB contains significant amounts of dolomite and limestone and is suspected to be, at least partially, a source area for the Lower Alluvial Unit. By comparison, the perched aquifer, which is a predominantly sodium-sulfate type, contains generally lower percentages of calcium and bicarbonate than the regional aquifer.

The differences in hydraulic characteristics between the two aquifers also may indicate differences in the sediment that the aquifers are composed of, but hydraulic characteristics are not particularly useful in assessing the distance of source(s) from the study area. Hydraulic conductivity values from aquifer tests are greater in the regional 
aquifer than in the perched aquifer; however, this is not the case for vertical hydraulic conductivities obtained from falling head permeameter tests. Vertical conductivity values for the perched aquifer are typically higher than in the regional aquifer. The differences between the two sets of values may indicate that the sand layers in the regional aquifer dominate lateral hydraulic conductivity, while the fine-grained layers in this unit are stronger barriers to vertical flow.

Although the overall reliability of hydraulic conductivity values derived from aquifer tests may be questionable, the different directions of apparent spatial trends in hydraulic conductivity zones may imply that different regional drainage directions existed during deposition of the Upper and Lower Alluvial Units.

\section{Age and Origin of Sediments}

The volcanic component observed in the Lower Alluvial Unit beneath GAFB is a useful index for assessing the depositional sequence, relative age, and possibly, the sediment source areas for the study area. The differences in sediment composition beneath GAFB are interpreted to reflect either a change in the composition of the source area south of the base due to movement along the San Andreas fault and/or a transition in drainage origin and/or direction.

A significant change in regional drainage occurred approximately 500,000 to 730,000 years ago due to the rise of the San Bernardino and San Gabriel Mountains along 
the San Andreas fault south of the study area (Meisling, 1984). The aquitard appears to span this transition: its deeper portions contain volcanics, whereas sand in the upper portion and depositionally above the aquitard lacks volcanics.

XRD testing results appear to indicate that, from a qualitative standpoint, the nature of the aquitard beneath GAFB is similar basewide, and it may have been derived from the same source area. The presence of calcite, dolomite, and volcanics in the aquitard's deeper sand unit may indicate a sediment source east of the base where these constituents are abundant.

The aquitard appears to be a fresh-water, lacustrine feature rather than an ephemeral saline playa feature. This is supported not as much by the minerals that were present in the XRD samples, but by the absence of indicator minerals such as evaporites and authigenic silicates including zeolites that form in saline conditions.

Based on the above discussion, the Upper Alluvial Unit may be younger than 500,000 years old, and is probably derived from fluvial sources originating south of GAFB and moving northward as a result of regional drainage transitions accompanying mountain building along the San Andreas fault. The heterogeneous nature of the Upper Alluvial Unit probably reflects braided stream deposits interbedded with fine-grained overbank, pond, and/or deltaic deposits. The distribution of hydraulic conductivity appears to indicate a northwest trend to the deposits. 
The Lower Alluvial Unit may be older than approximately 500,000 years. The similarity of Lower Alluvial Unit volcanics to those in the fan along the small unnamed range east of GAFB suggests that the unit may be derived from this range. However, the San Bernardino and San Gabriel Mountains cannot necessarily be ruled out as a potential source for the Lower Alluvial Unit. Although limited in extent, there are volcanics in the Transverse Ranges (Bortungo and Spittler, 1986), and their presence in the Lower Alluvial Unit could indicate that the area's ancestral drainage sampled volcanics during evolution of and movement along the San Andreas fault.

It is also worth mentioning that the regional drainage in the Mojave Desert was toward the south prior to the rise of the Transverse Ranges (Meisling, 1984). Therefore, the Lower Alluvial Unit may have been derived, at least in part, from sources to the north. 


\section{CONCLUSIONS}

The primary conclusions of this thesis generally support the 3-layer conceptual hydrogeologic model for GAFB suggested by Montgomery Watson (1995); that is, there do appear to be three primary lithologic units beneath GAFB that can be distinguished from each other by sediment types and source area. Using the volcanic component as an indicator, the Upper and Lower Alluvial Units appear to be derived from different source areas. The Upper Alluvial Unit may contain fluvial deposits and may not be part of the Victorville Fan as is suggested in the existing conceptual site model. Because the Lower Alluvial Unit contains volcanic clasts, its source is suspected to be the mountain range east of GAFB. This remains an area for further investigation.

The perched and regional aquifers appear to contain quantifiable differences in hydrogeologic characteristics such hydraulic conductivity, and in groundwater quality, including general water quality parameters and metals content. These differences may be due to the differences in composition of the Upper and Lower Alluvial Units containing the aquifers.

The aquitard appears to be of lacustrine origin, as suggested by the existing model. This observation is based not as much by the minerals identified using XRD testing, but by the absence of indicator minerals such as evaporites or zeolites that might indicate saline playa conditions. 
Where the findings of this thesis differ most from the existing model is in the interpretation of the configuration of the aquitard in the southeastern portion of GAFB. Conditions in this area appear different from those elsewhere on base, with the aquitard apparently offset downward. Once again, while this investigation did not prove this condition, additional work could be performed, including age-dating of the fine-grained units basewide to establish a greater basis for comparison. This dating could be performed using a variety of techniques and/or by examining fossils such as ostracods or pollen.

The findings of this investigation indicate that the study area is characterized by a complex hydrogeologic environment. The alluvial, fluvial, and lacustrine sediments beneath GAFB appear to possess source area indicators that record a history of Pleistocene change and evolution in the Mojave Desert. 


\section{REFERENCES CITED}

Bookman-Edmonston Engineering, Inc., 1994, Regional water management plan for the Mojave Water Agency, Apple Valley, California, 135 p.

Bortungo, E.J., and Spittler, T.E., 1986, Geologic map of the San Bernardino quadrangle, California: California Department of Mines and Geology, Map No. 3A.

Boyle Engineering Corporation, 1987, Alter base water supply, George AFB, Victorville, $\mathrm{CA}$, well field analysis, $54 \mathrm{p}$.

Boyle Engineering Corporation, 1988, Domestic water supply review and evaluation, George AFB, San Bernardino County, California, Sections 2, 3, and 4.

Brown, William J., Wells, S.G., Enzel, Y., Anderson, R.Y., and McFadden, L.D., 1990, The Late Quaternary history of pluvial Lake Mojave-Silver Lake and Soda Lake Basins, California in At the end of the Mojave: Quaternary studies in the Eastern Mojave Desert: special publication of the San Bernardino County Museum Association, p. 55-72.

Dibblee, T.W., Jr., 1960, Preliminary geologic map of the Victorville Quadrangle, California: U.S. Geologic Survey, Mineral Investigations Field Studies Map MF229 , scale $1: 62,500$.

Dibblee, T.W., Jr., 1967, A real geology of the western Mojave Desert, California: United States Geological Survey Professional Paper 522, 153 p.

Enzel, Yehouda, Anderson, R.Y., Brown, W.J., Cayan, D.R, and Wells, S.G., 1990, Tropical and subtropical moisture and southerty displaced North Pacific storm track: factors in the growth of Late Quaternary lakes in the Mojave Desert in Betancourt, J.L. and A.M. Mackay, Eds., Proceedings of the sixth annual Pacific Climate (PACLIM) workshop, March 5-8, 1989: California Department of Water Resources, Interagency Ecological Studies Program Technical Report 23, 233 p.

Folk, Robert L., 1980, Petrology of sedimentary rocks: Hempill, Austin, Texas, 185 p.

Glazner, Allen F., Walker, J.D., Bartley, J.M., Fletcher, J.M., Martin, M.W., Schermer, E.R., Boetcher, S.S., Miller, J.S., Fillmore, R.P., and Linn, J.K., 1994, Reconstruction of the Mojave Block in Geological Investigations of an Active Margin: Geological Society of America Cordilleran Section Guidebook, 27th Annual Meeting, San Bernardino, California, March 21-23, 1994, p. 3-30. 
Hardt, William F., 1971, Hydrologic analysis of Mojave River Basin, California using electric analog model: USGS Open-File Report 72-157, 83 p.

IT Corporation, 1992, Remedial Investigation, Operable Unit 2, JP-4 spill, George Air Force Base, California, v. 1 .

Izbicki, John A., Martin, P., and Michel, R.L., 1994, Source, movement, and age of groundwater in the upper part of the Mojave River basin, California, USA: publication of the U.S. Geological Survey, $15 \mathrm{p}$.

James M. Montgomery, Consulting Engineers, Inc. (JMM), 1992, Remedial Investigation report, Operable Unit 1, George Air Force Base, California, v.1. 1993, Feasibility Study, Operable Unit 1, George Air Force Base, California, v.1.

Jefferson, George T., 1986, Fossil vertebrates from Late Pleistocene sedimentary deposits in the San Bernardino and Little San Bernardino Mountains region in Geology around the margins of the eastern San Bernardino Mountains: Inland Geological Society, v. 1, p. 109-116.

McNeil, Mary Deligant, 1963, The Victorville Pediment, San Bernardino County, California, its geology and climatic significance (master's thesis): University of California at Los Angeles, $113 \mathrm{p}$.

Meisling, K.E., 1984, Neotectonics of the North Frontal Fault System of the San Bernardino Mountains, Southern California, Cajon Pass to Lucerne Valley (Ph.D. dissertation): California Institute of Technology, Pasadena, California, 120 p.

Miller, E.L., 1977, Geology of the Victorville region, California (Ph.D. dissertation): Rice University, Houston, Texas, $68 \mathrm{p}$.

Montgomery Watson, 1995. Installation Restoration Program, Operable Unit 1 pre-design study, George Air Force Base, Victorville, California, v. 1 and 2.

Montgomery Watson, 1996a, Remedial Investigation, Operable Unit 3 landfill sites, George Air Force Base, Victorville, California, v. 1, 88 p.

Montgomery Watson, 1996b, Results of long-term groundwater monitoring, May 1996, George Air Force Base, Victorville, California, $42 \mathrm{p}$.

Scholle, Peter A., 1979, A color illustrated guide to constituents, textures, cements, and porosities of sandstones and associated rocks: American Association of Petroleum Geologists Memoir 28, $201 \mathrm{p}$. 
Science Applications International Corporation (SAIC), 1987, Installation Restoration Program, phase II - stage 2 confirmation/quantification, George Air Force Base, California $313 \mathrm{p}$.

Sheppard, R.A., and Gude, A.J., 3d, 1968, Distribution and genesis of authigenic silicate minerals in tuffs of Pleistocene Lake Tecopa, Inyo County, California: Geological Survey Professional Paper 597, 38 p.

Thompson, D.G., 1929, The Mojave Desert region, California, a geographic, geologic, and hydrogeologic reconnaissance: U.S. Department of the Interior, Water-Supply Paper 578, p. 1-29.

Umari, A., Martin, P., Schroeder, R.A., Duell, L F.W., Jr., and Fay, R.G., 1993, Potential for ground-water contamination from movement of wastewater through the unsaturated zone, upper Mojave River Basin, California: USGS Water-Resources Investigations Report 93-4137, p. 7-53.

University of Washington, 1961, Qualitative and quantitative identification of clay minerals by X-Ray diffractometric techniques, $7 \mathrm{p}$.

Wells, S.G., 1989, Late Quaternary paleohydrology of the eastern Mojave River drainage, Southern California, quantitative assessment of the Late Quaternary hydrologic cycle in large arid watersheds [Abstract]: Technical Completion Report, New Mexico Water Resources Research Institute in Cooperation with Department of Geology, University of New Mexico, p. 14.

Wells, S.G., Anderson, R.Y., Enzel, Y., and Brown, W.J., 1990, An overview of floods and lakes within the Mojave River drainage basin, implications for latest Quaternary paleoenvironments in southern California in At the end of the Mojave: Quaternary studies in the eastern Mojave Desert: special publication of the San Bernardino County Museum Association, p. 31-38.

Wells, S.G., Tinsley, J.C., McFadden, L.D., and Lancaster, N., 1994, Quaternary stratigraphy and dating methods, understanding geologic processes and landscape evolution in Southern California in Geological investigations of an active margin, Geological Society of America Cordilleran Section Guidebook, 27th Annual Meeting, San Bernardino, California, p. 120-213. 
Appendix A

Lithologic and Geophysical Logs for Boreholes RZ-01 Through RZ-04 


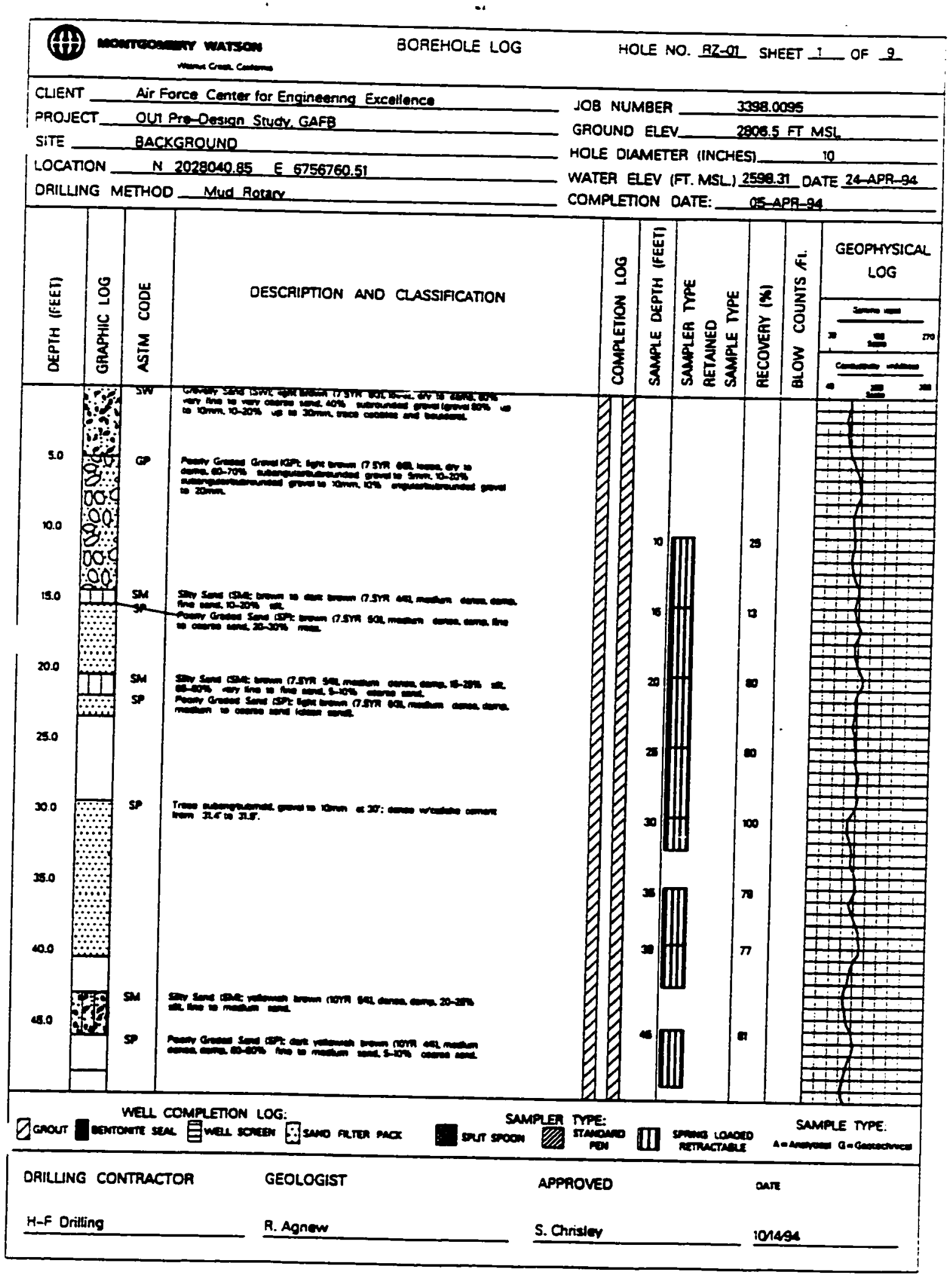




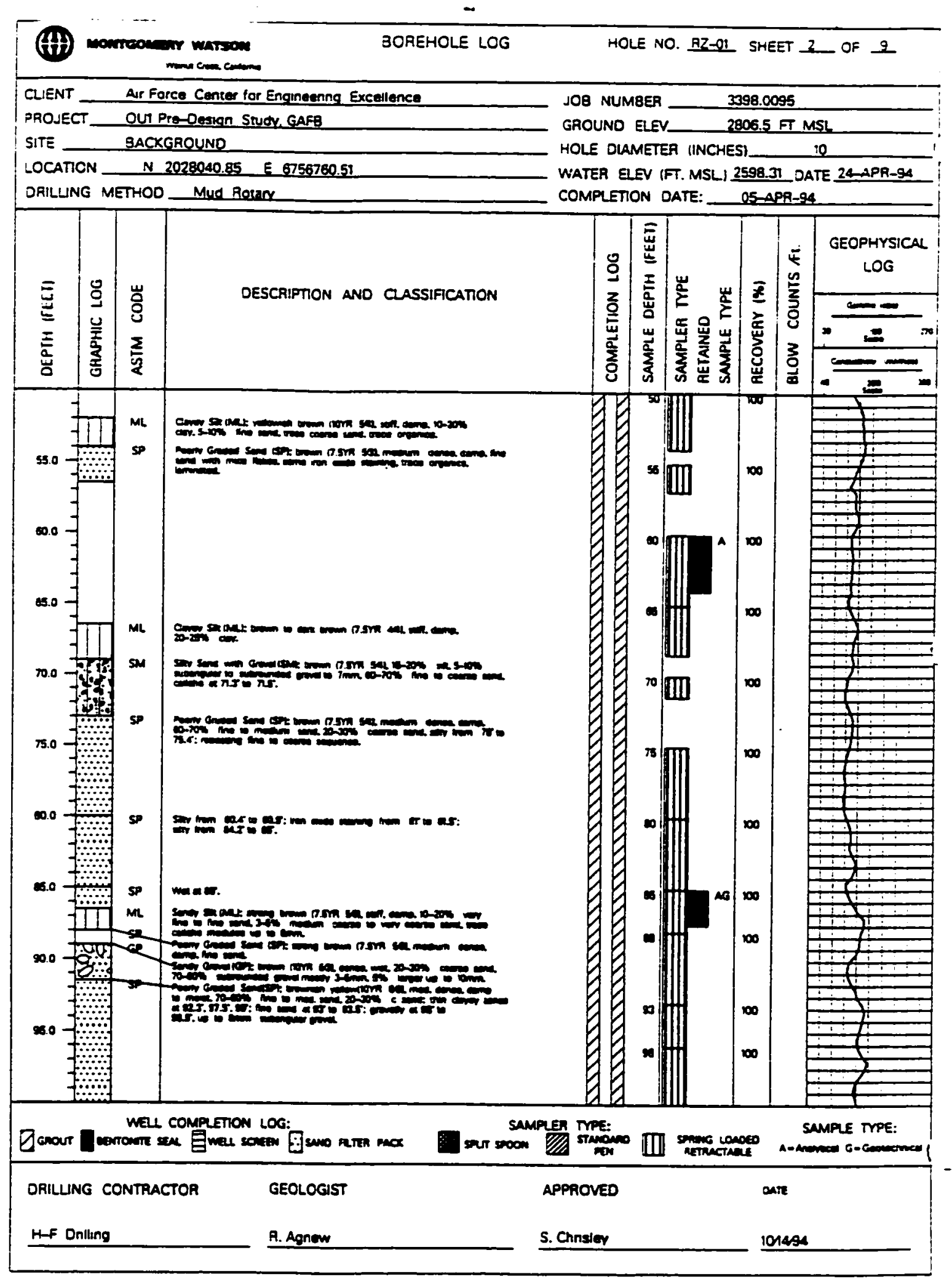




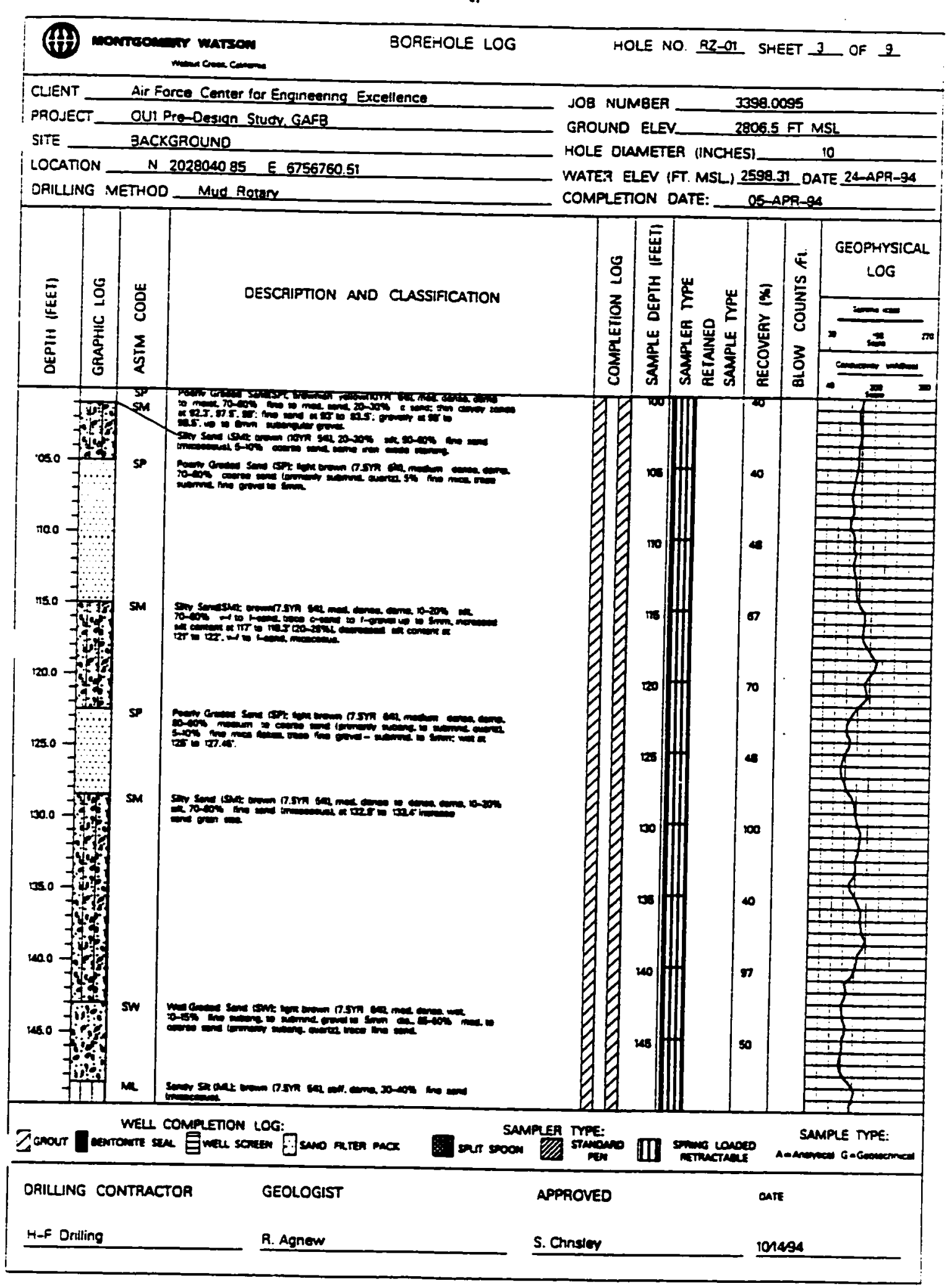




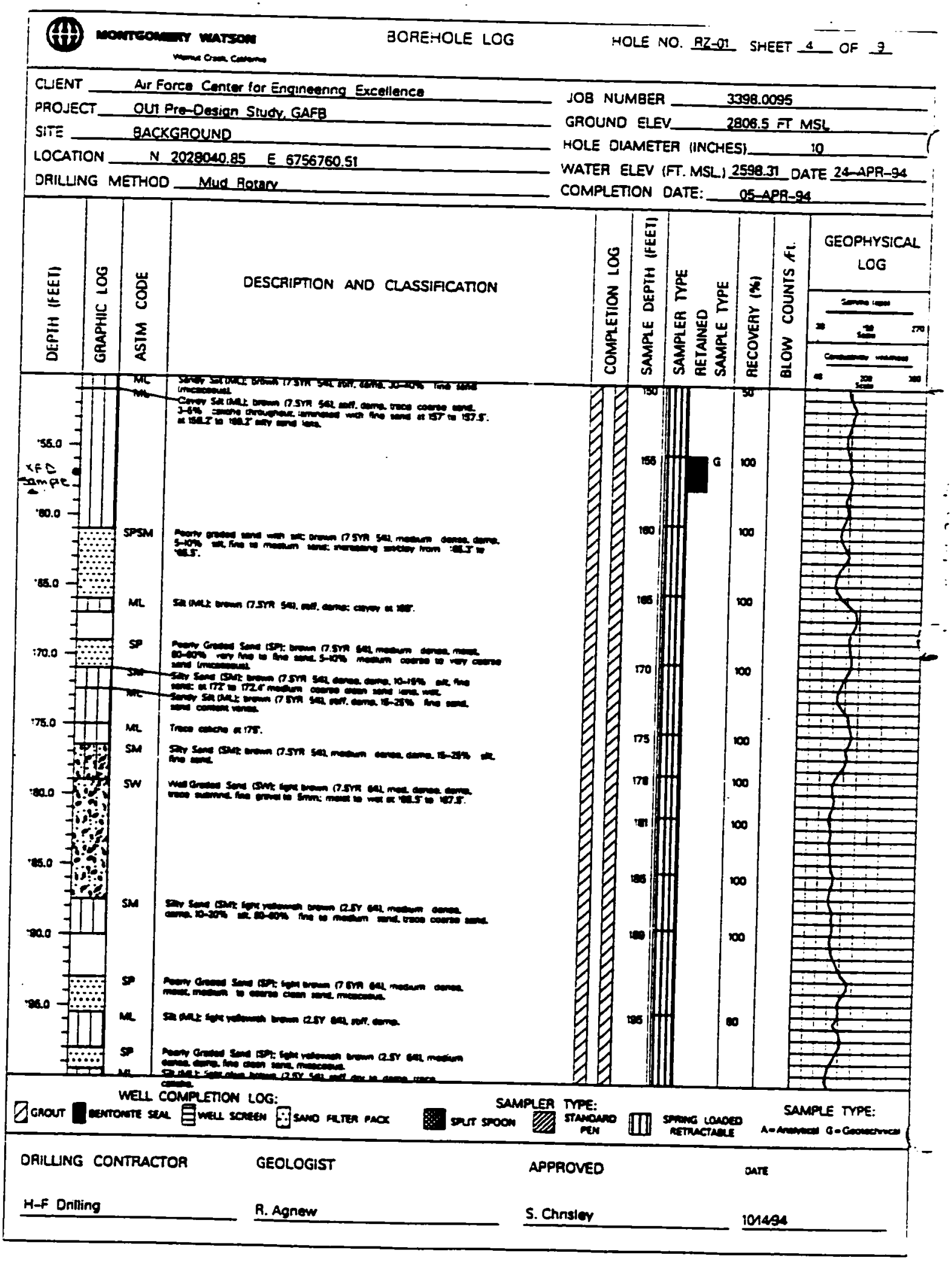




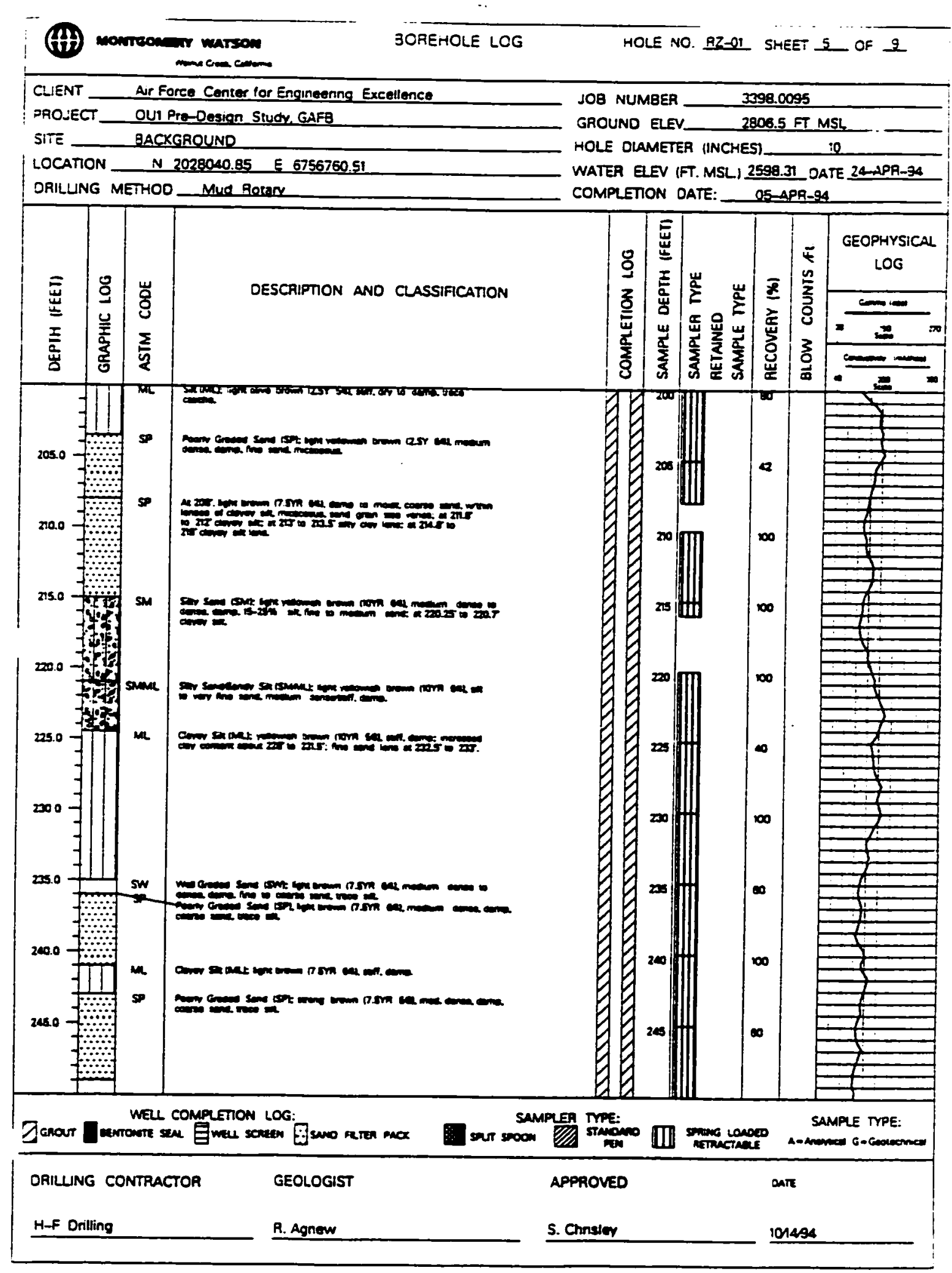




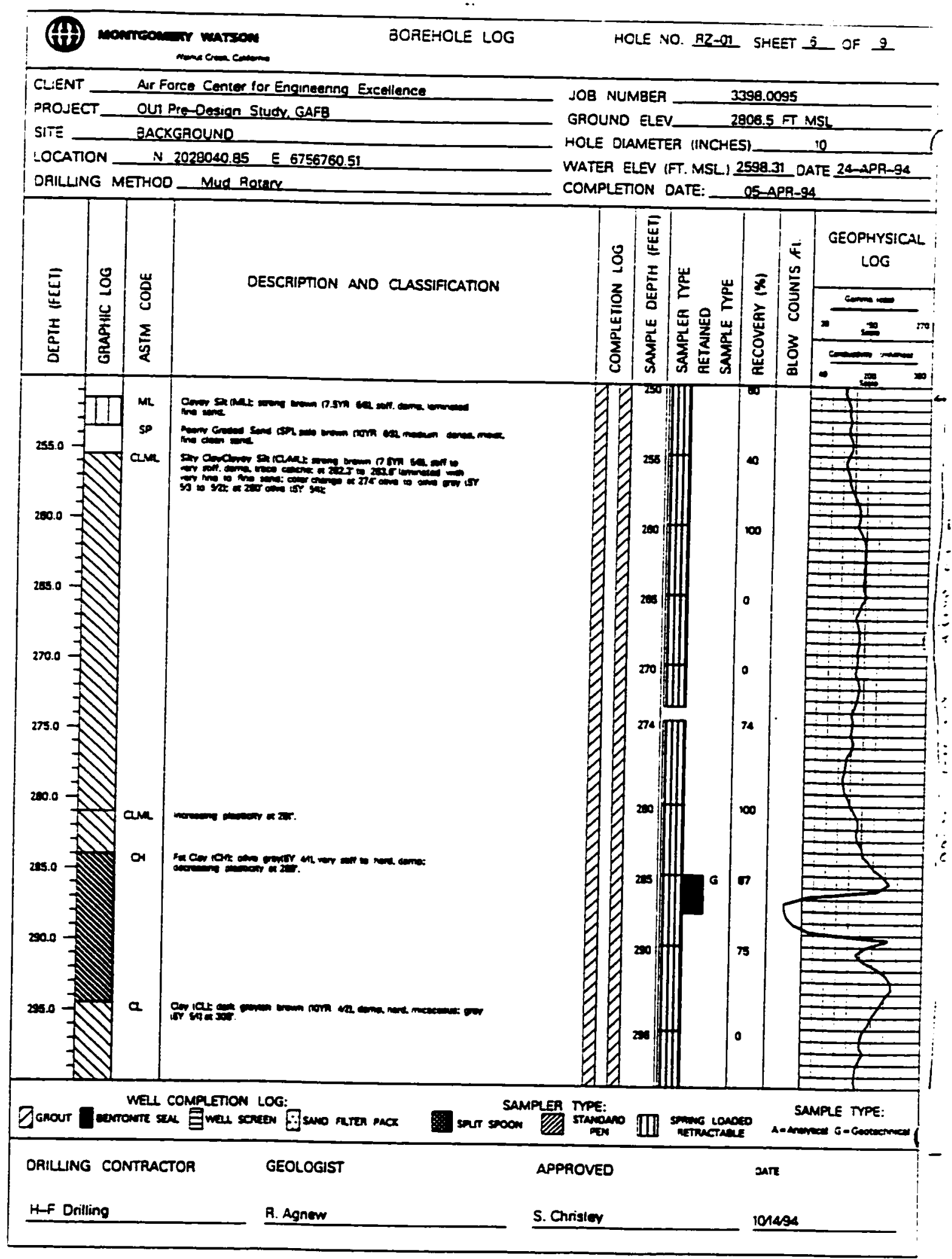




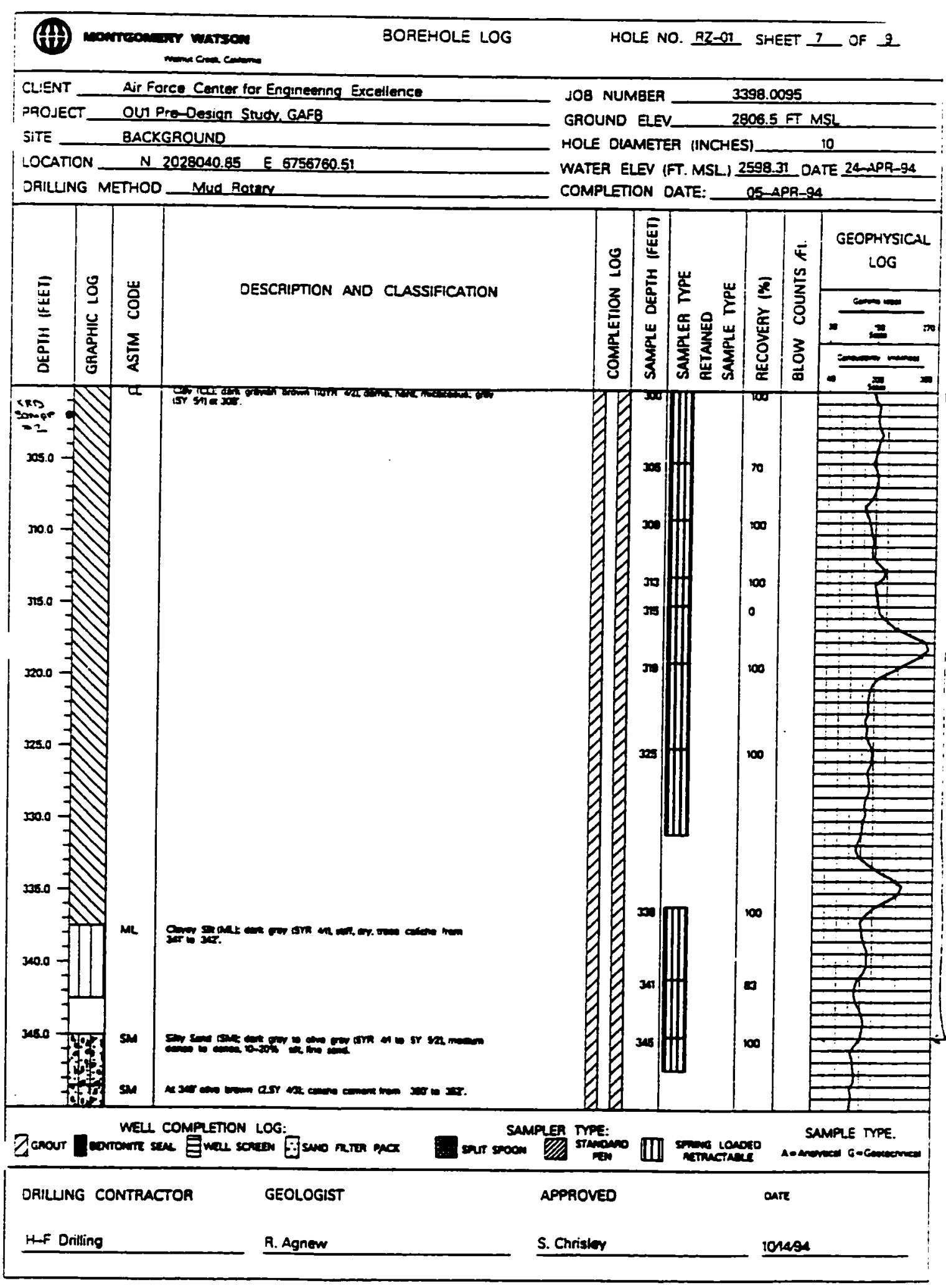




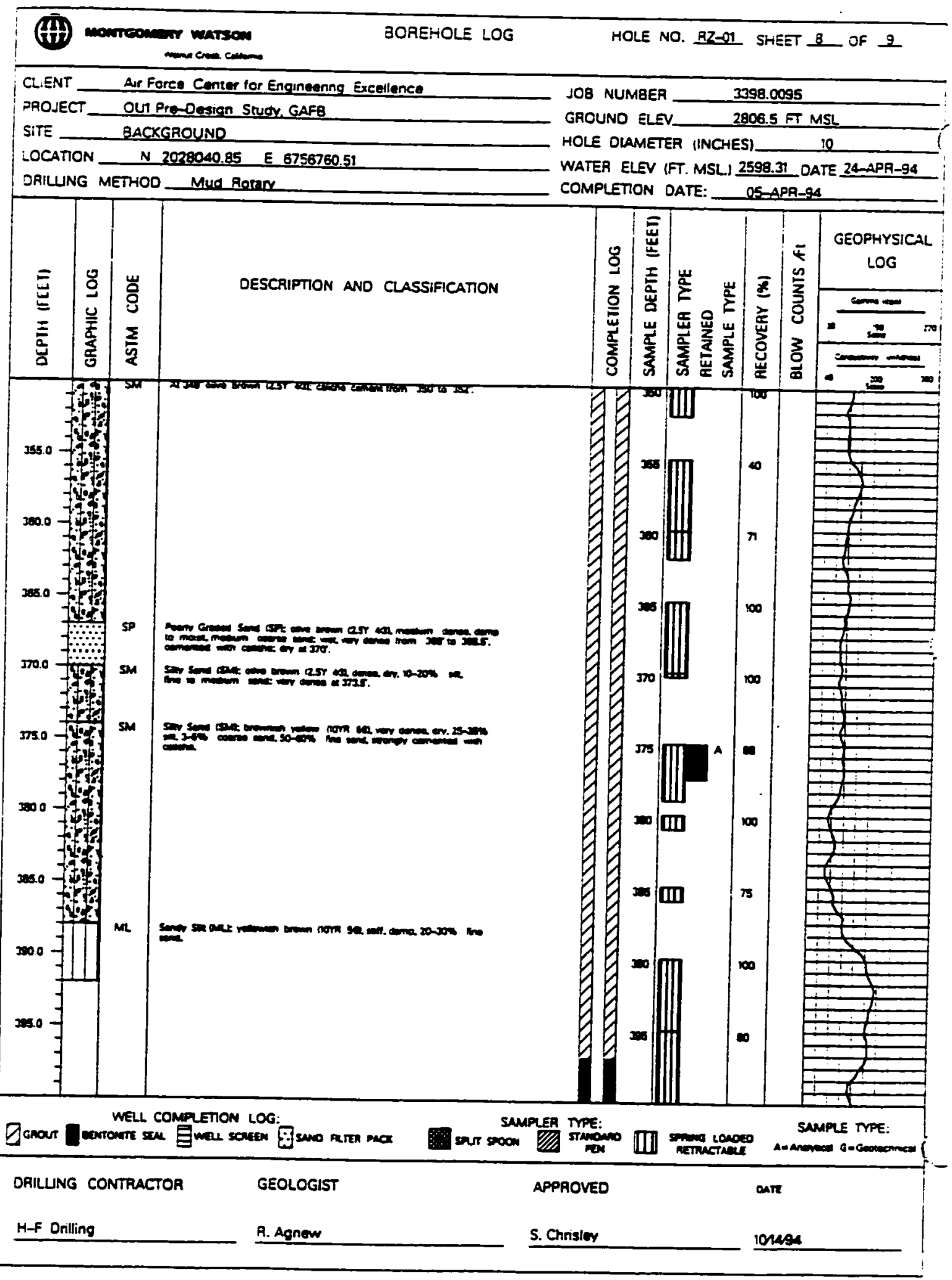




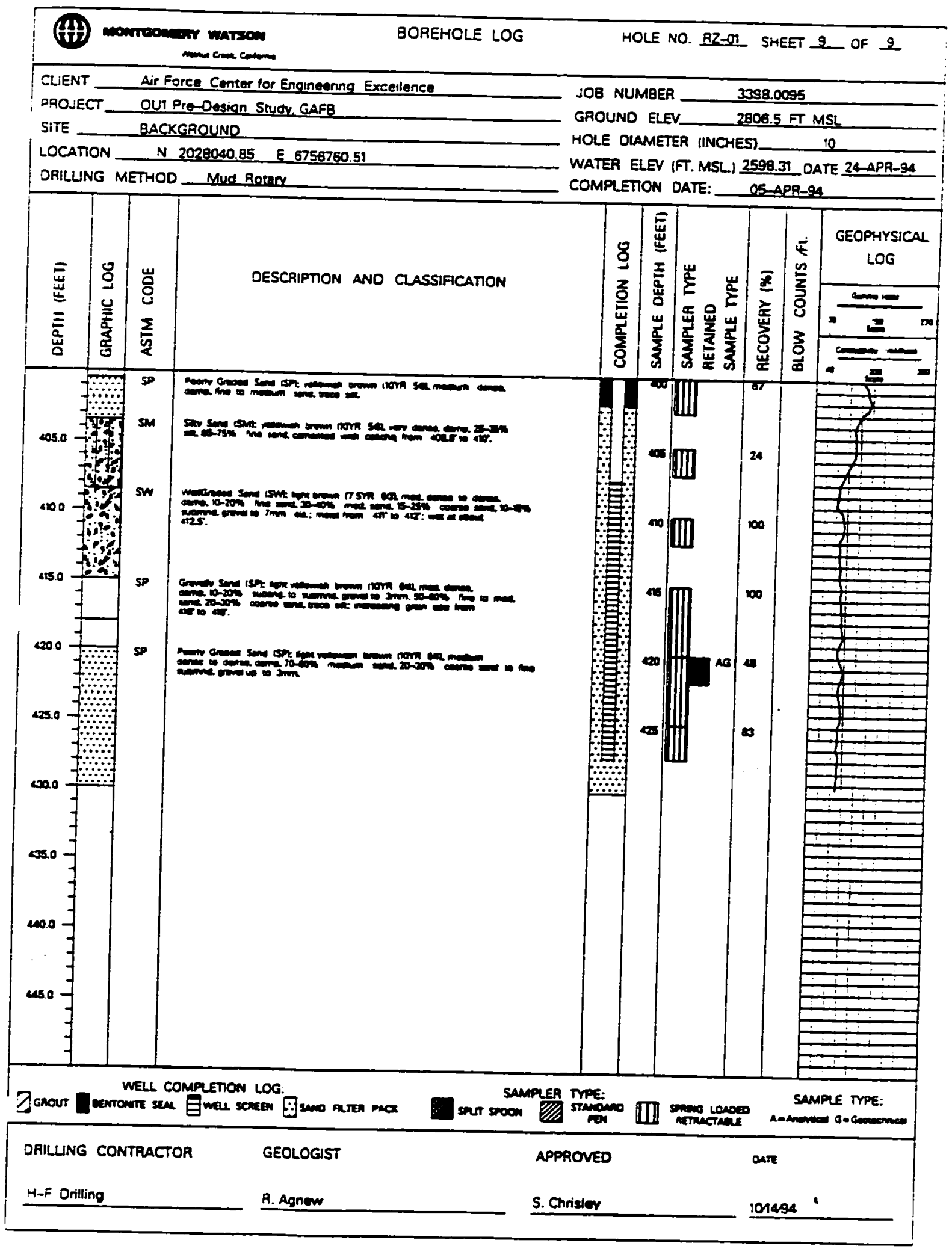




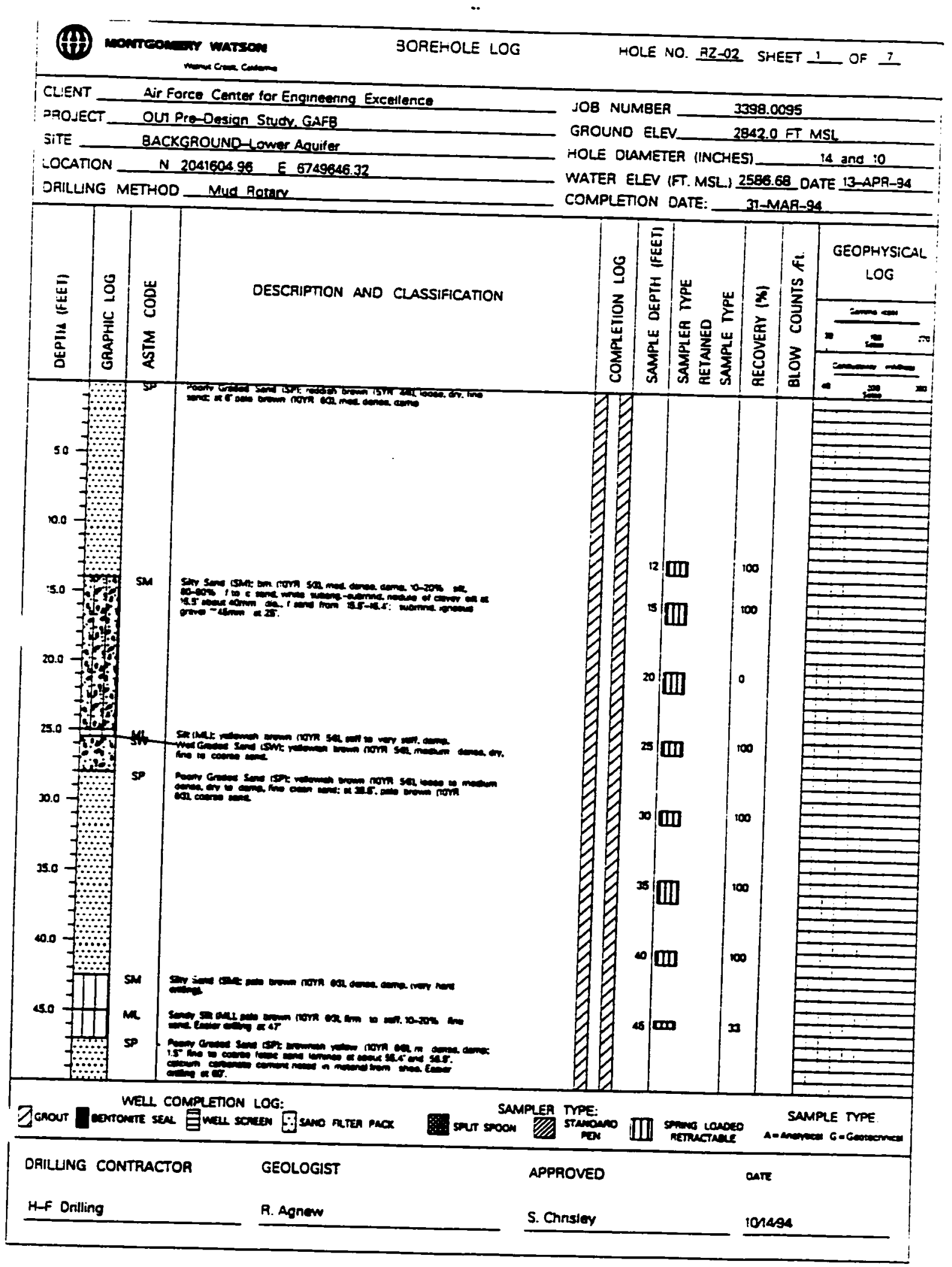




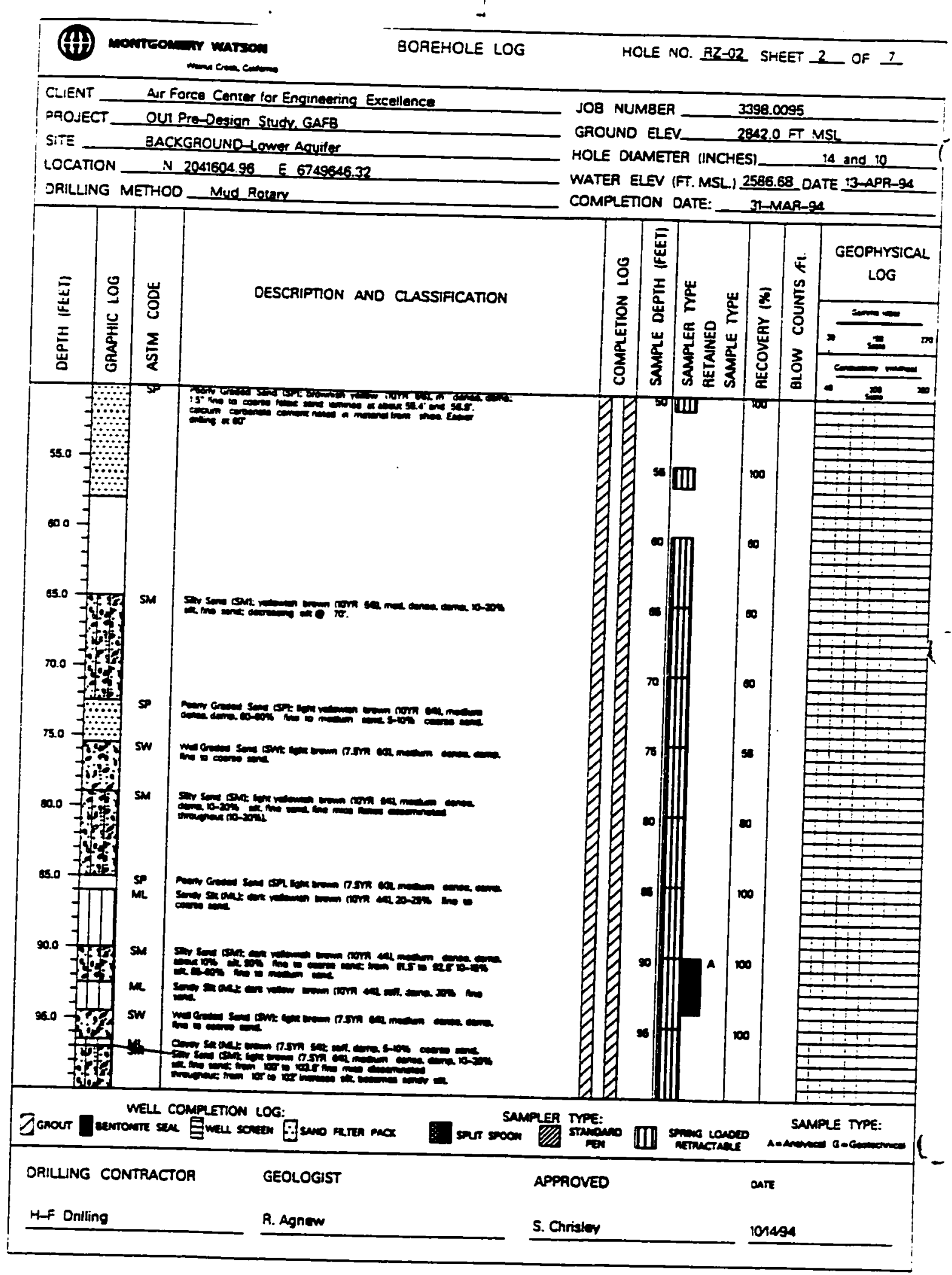




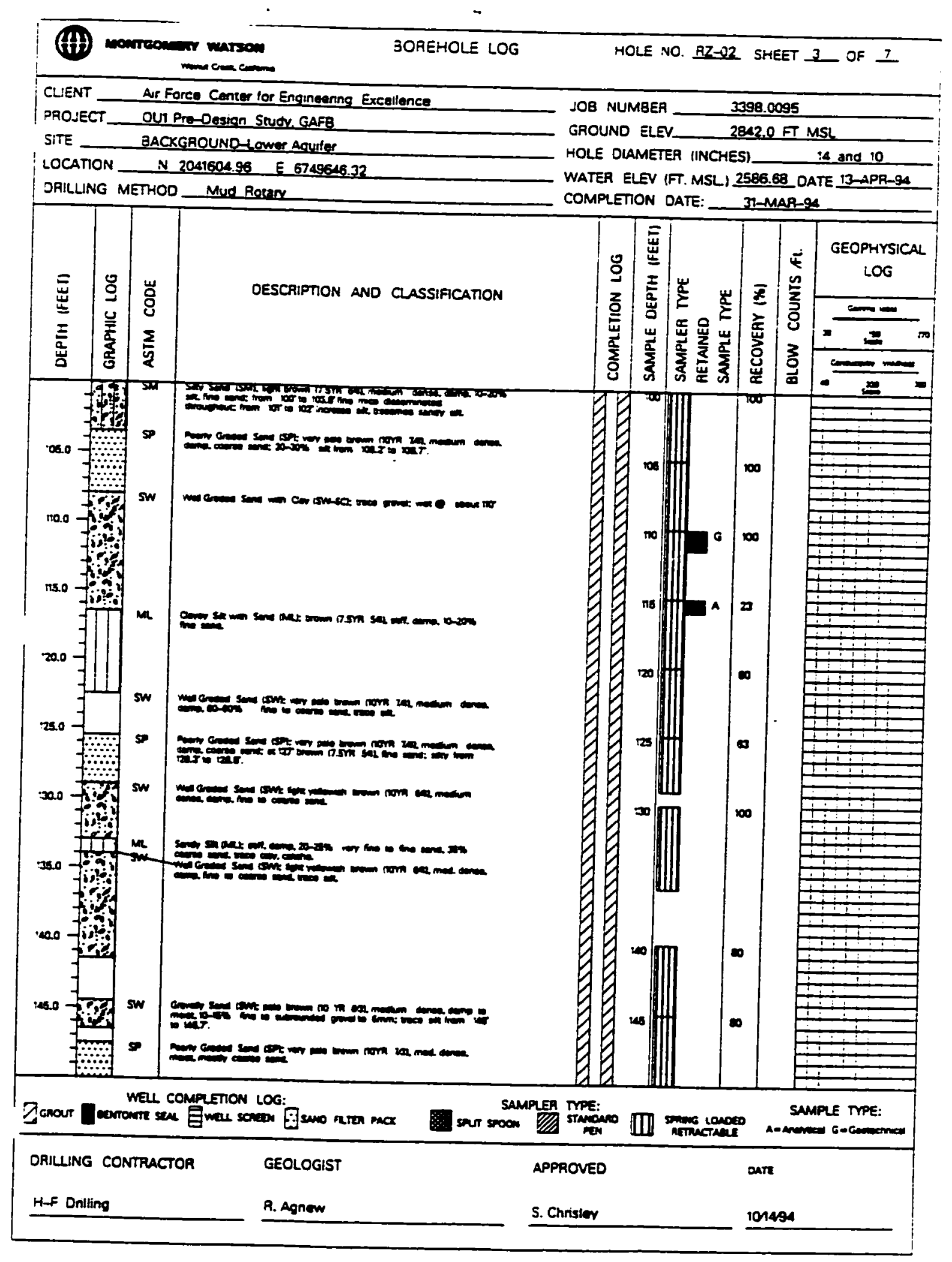




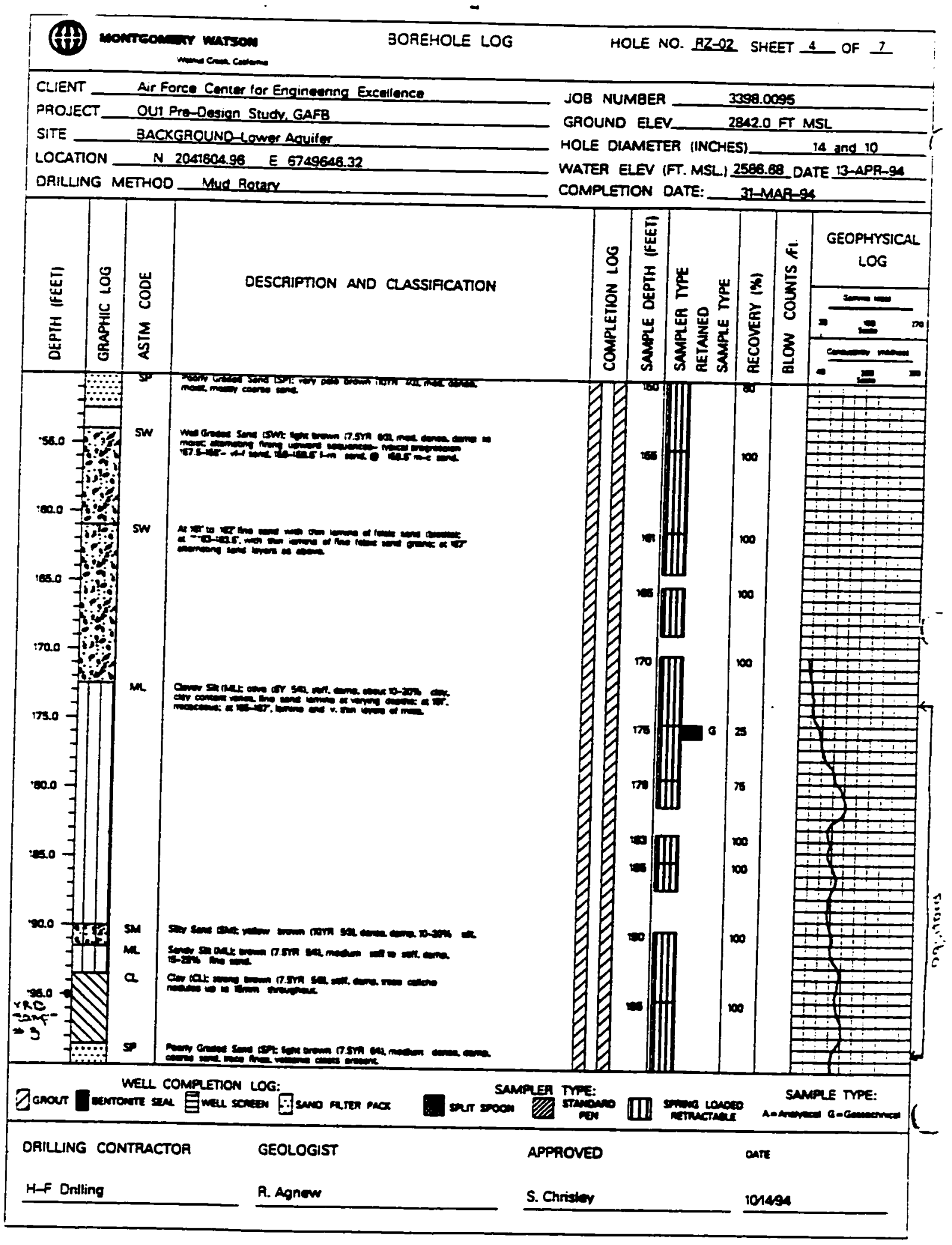




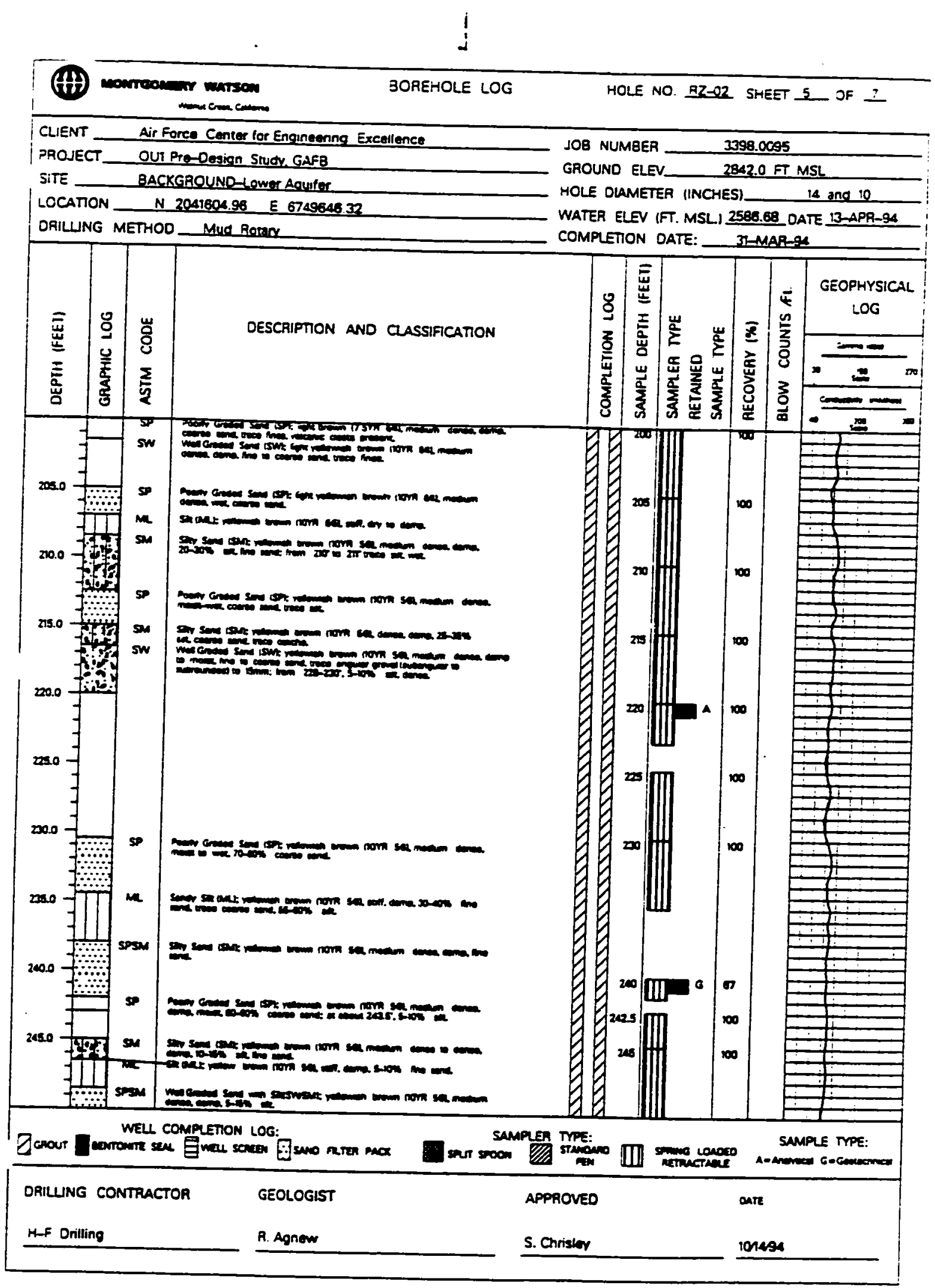




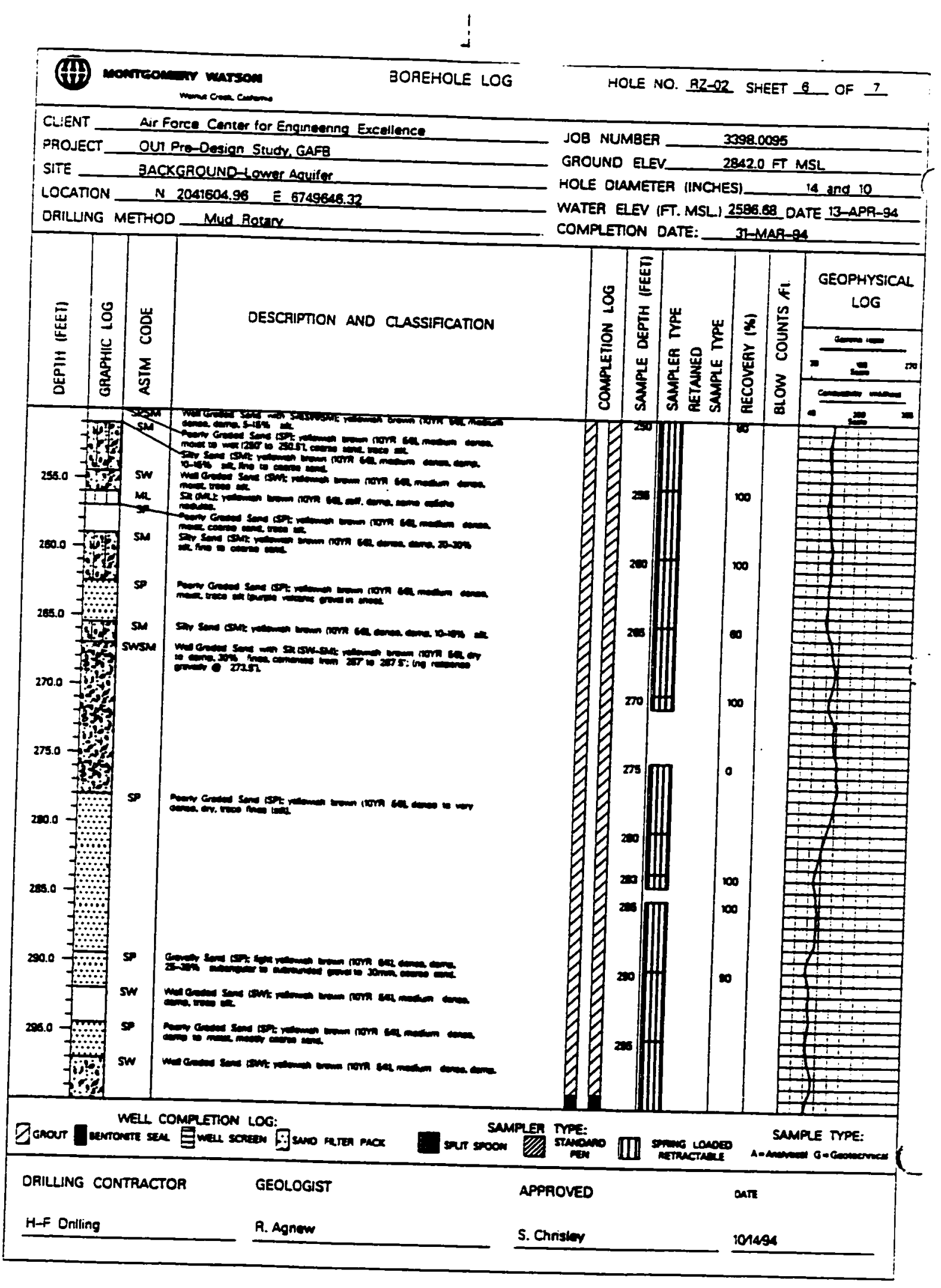




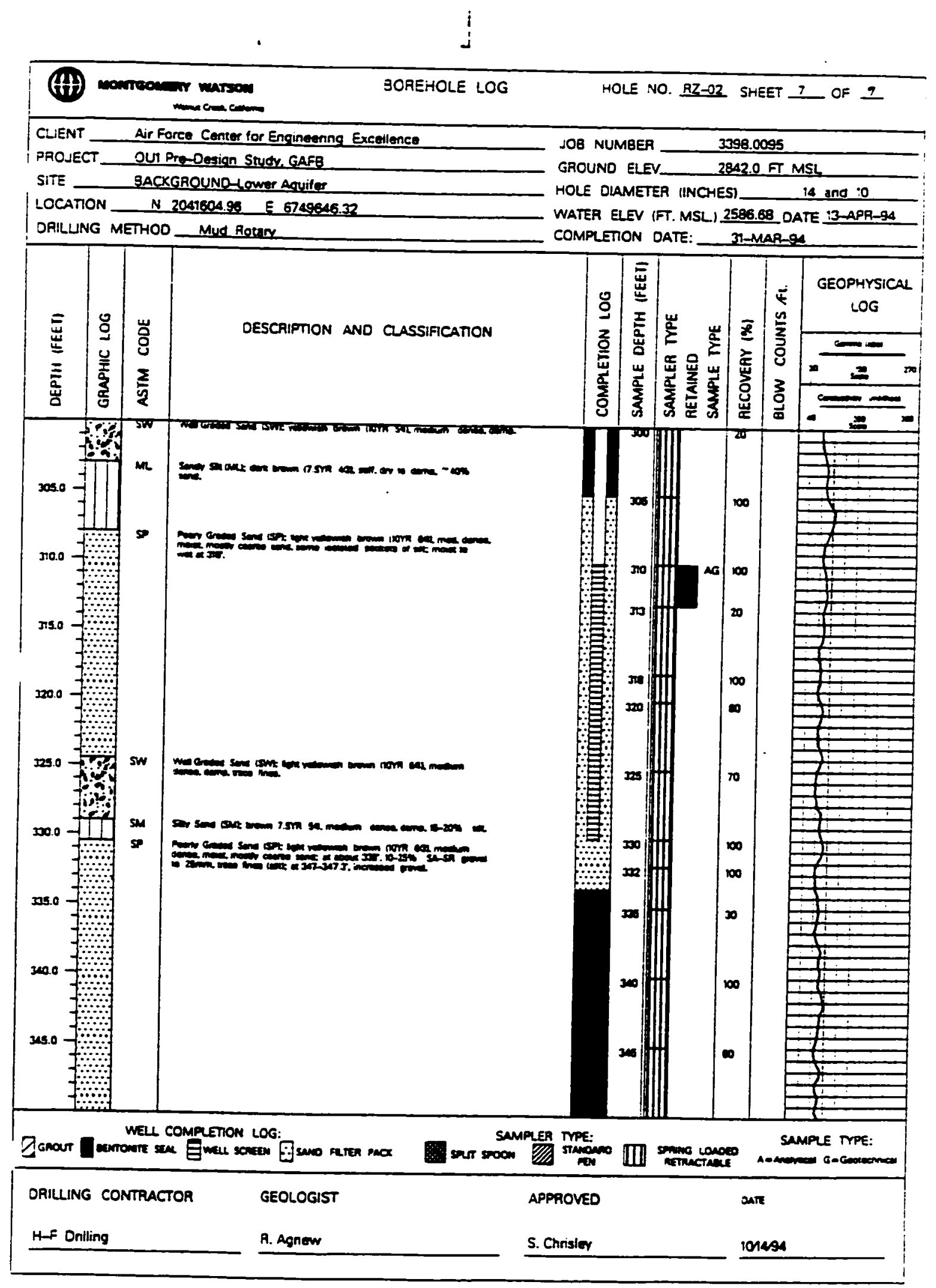




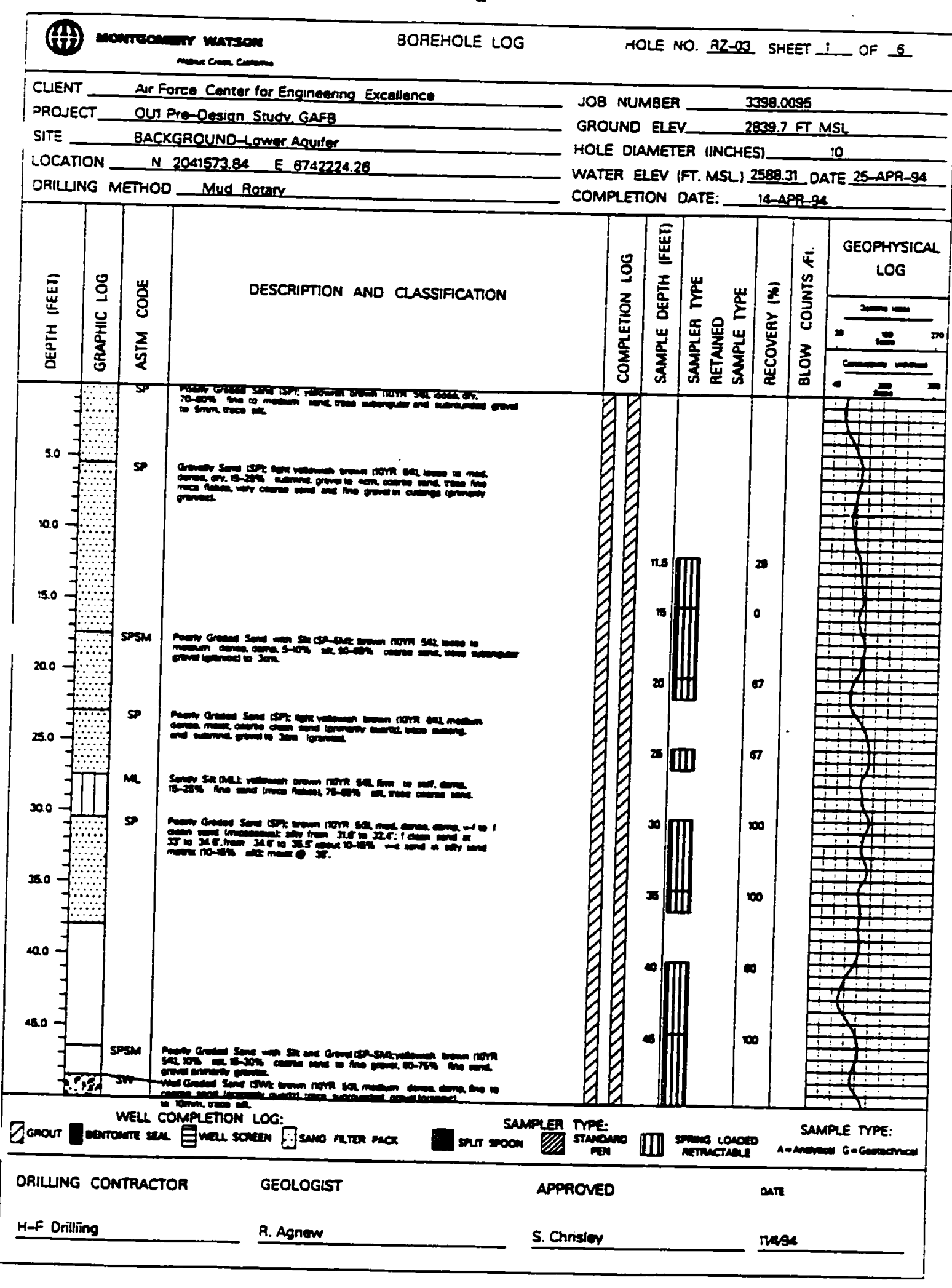




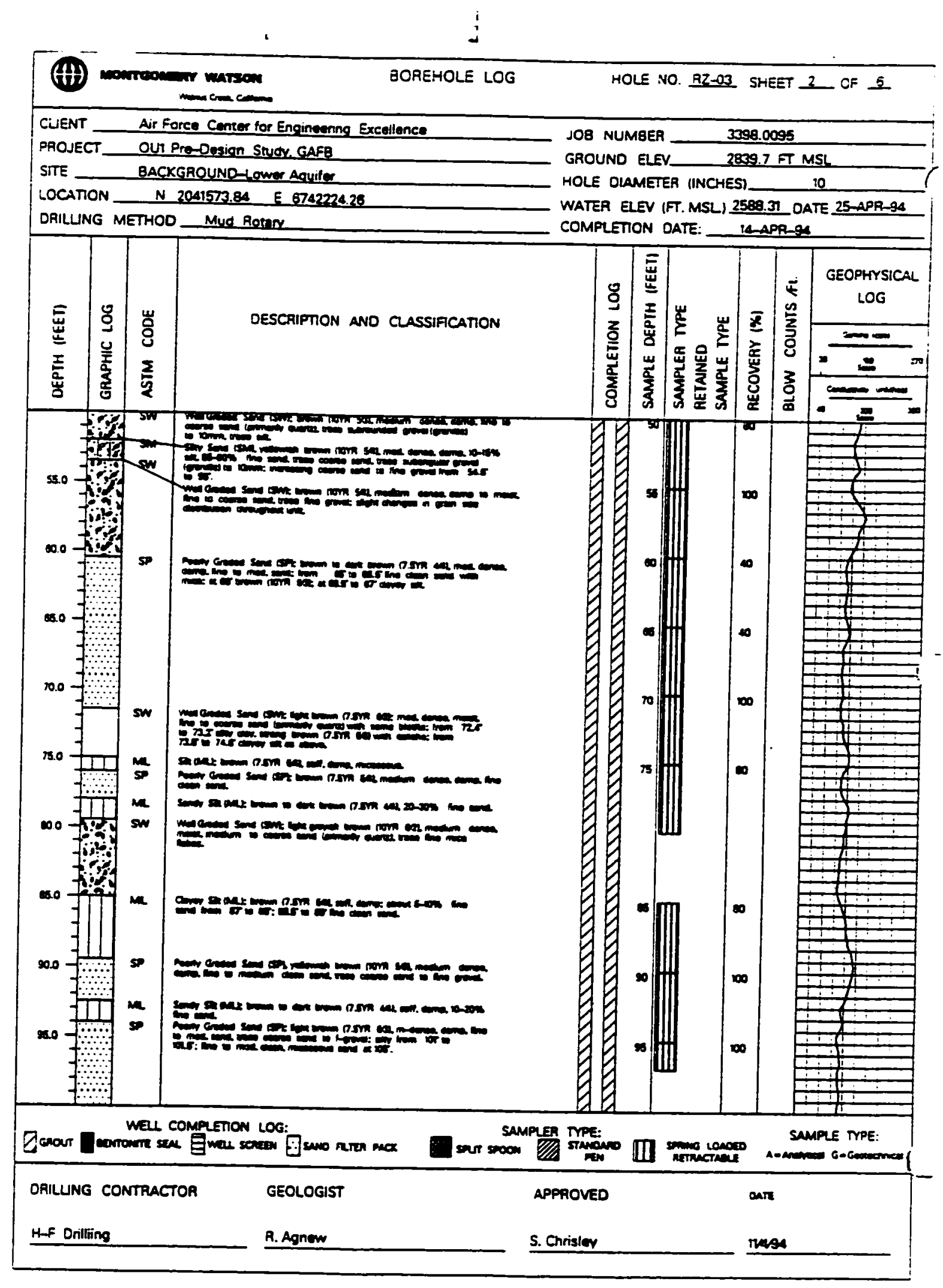




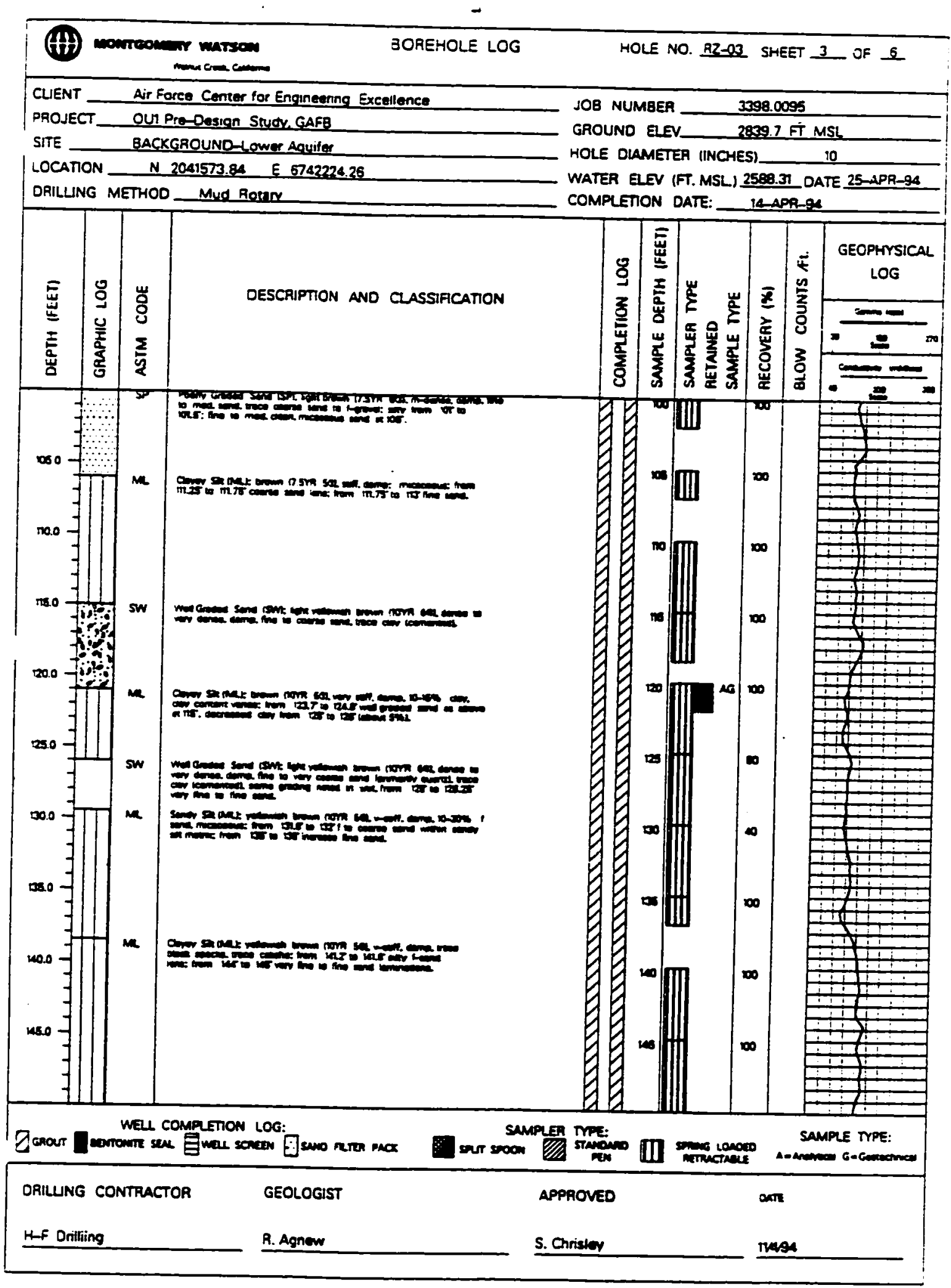




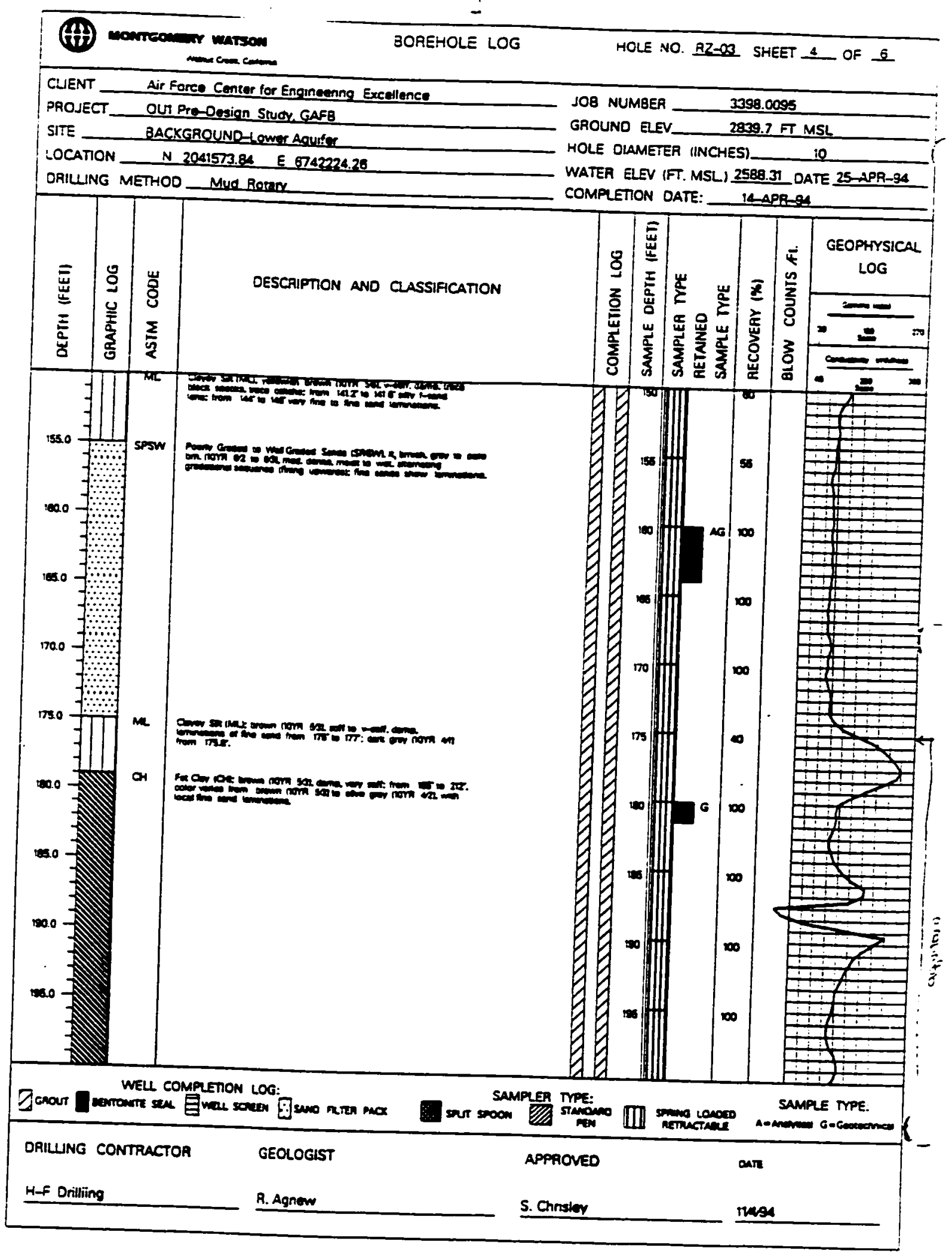




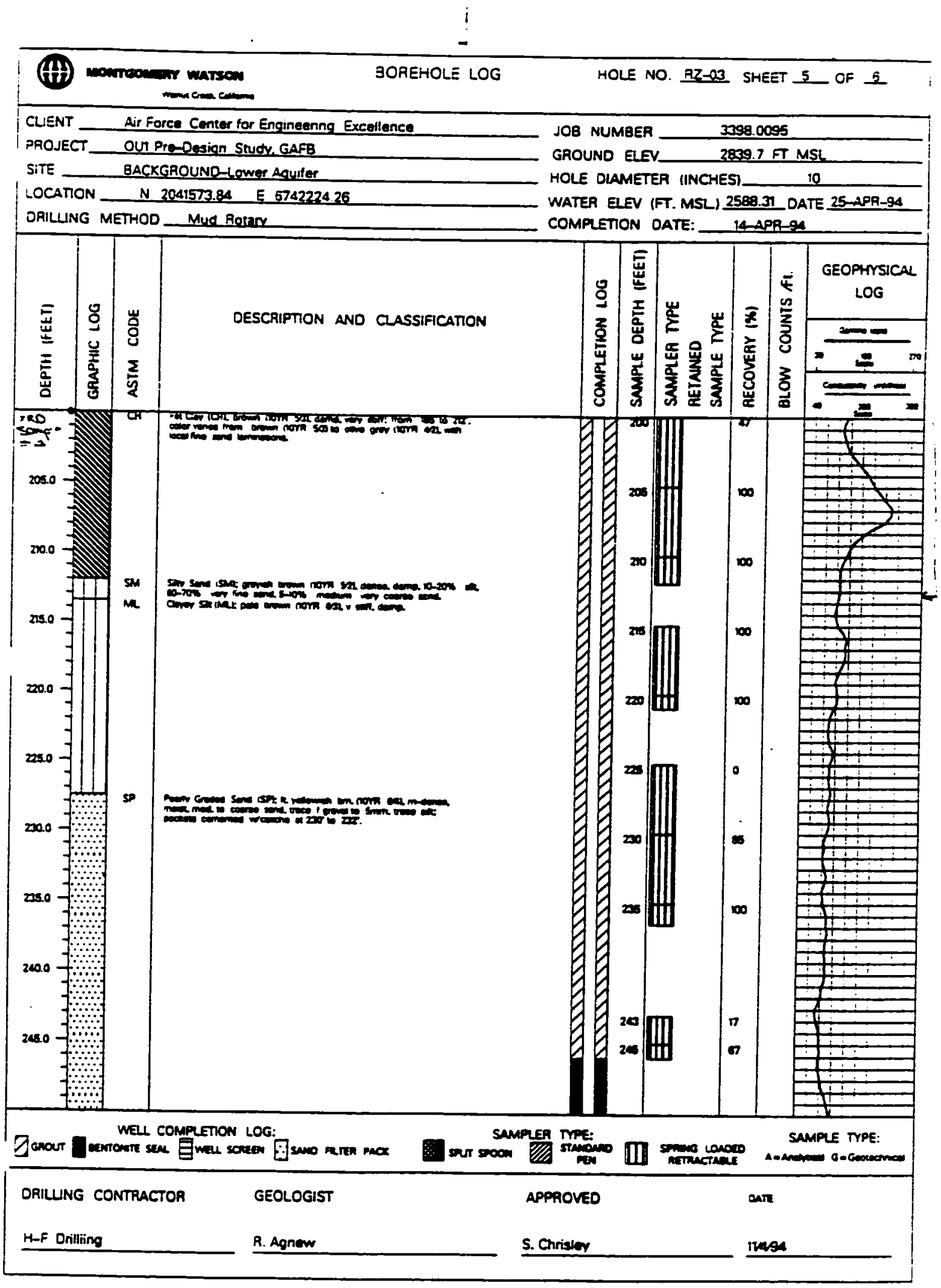




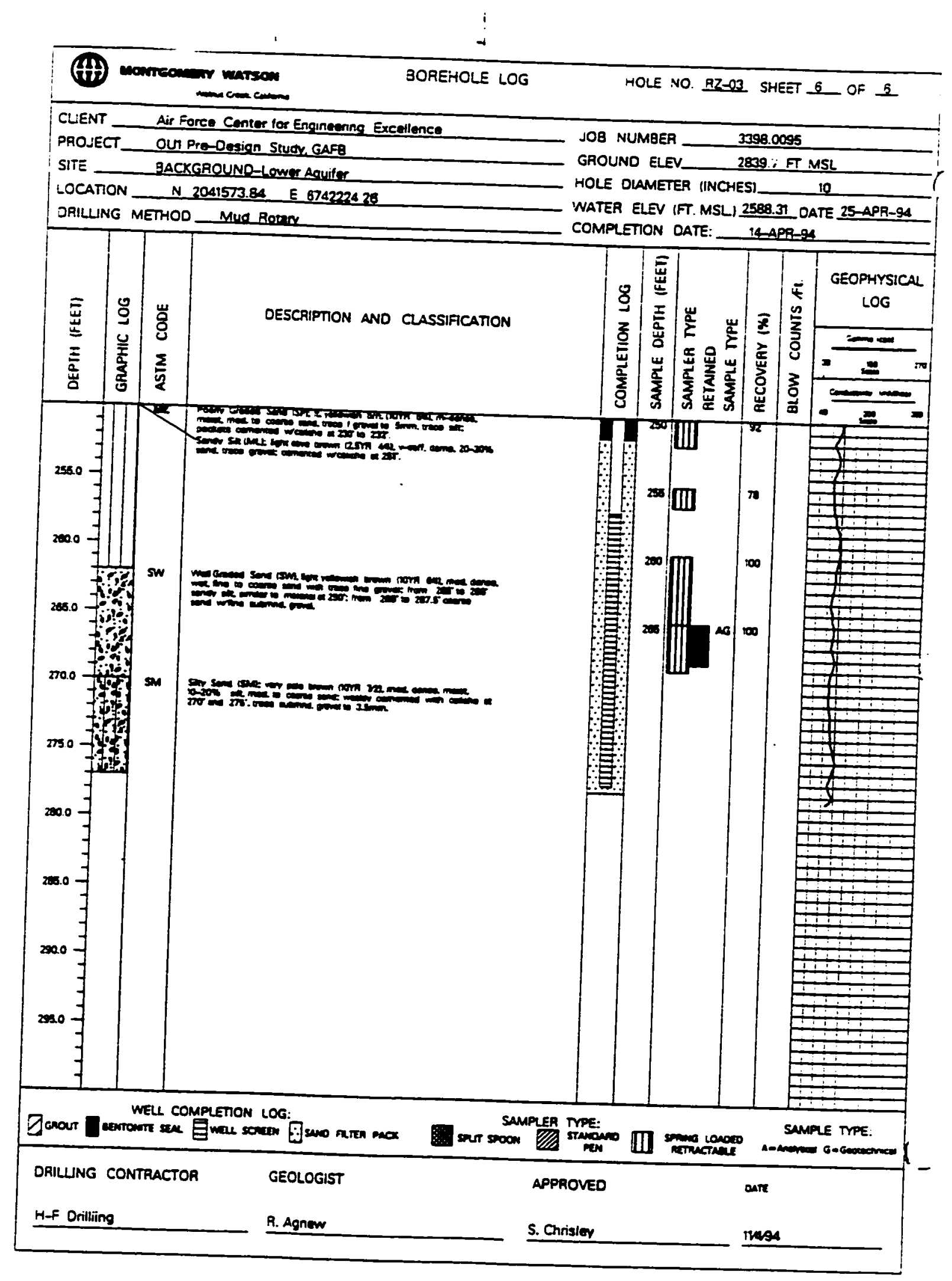




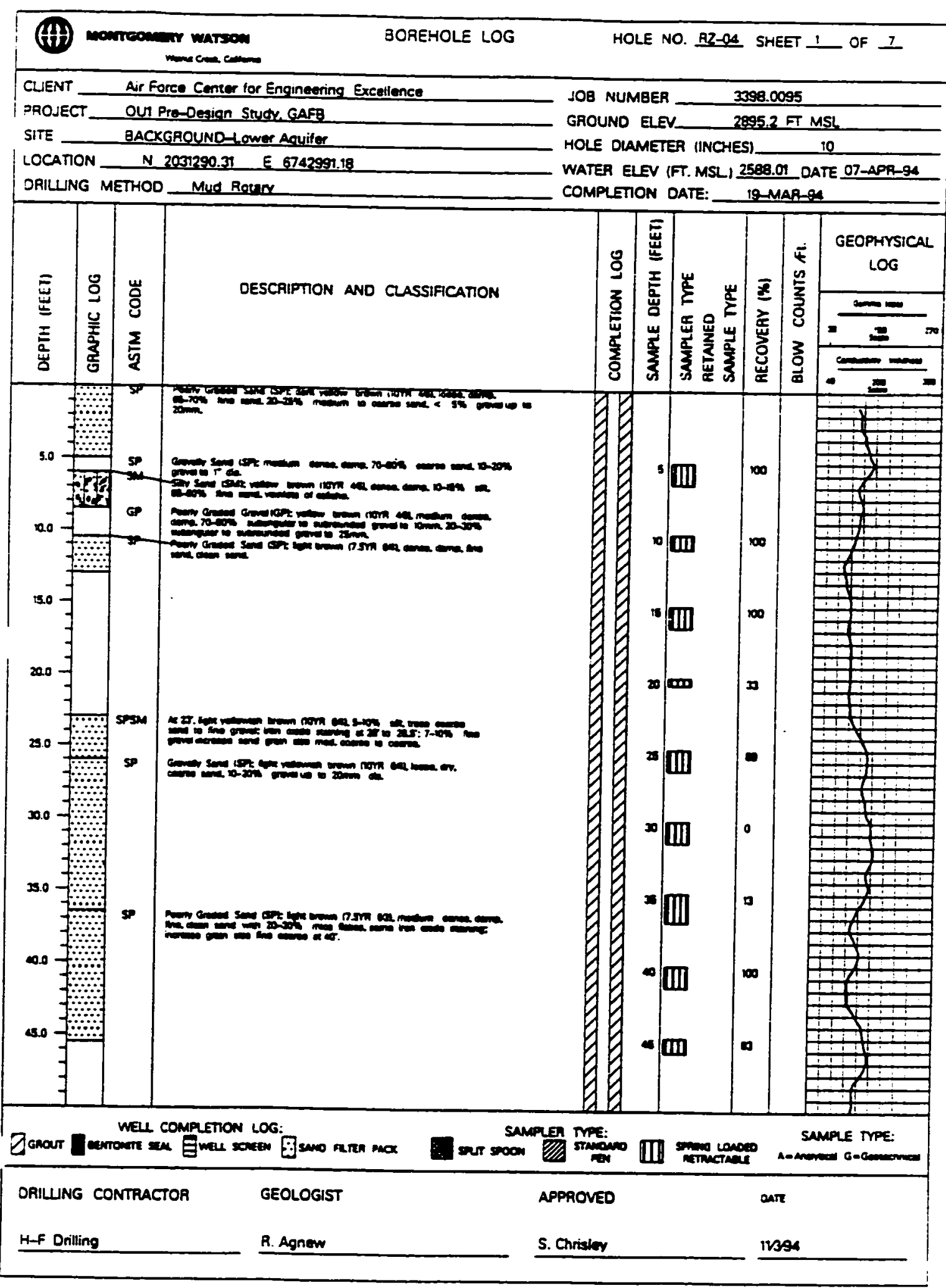




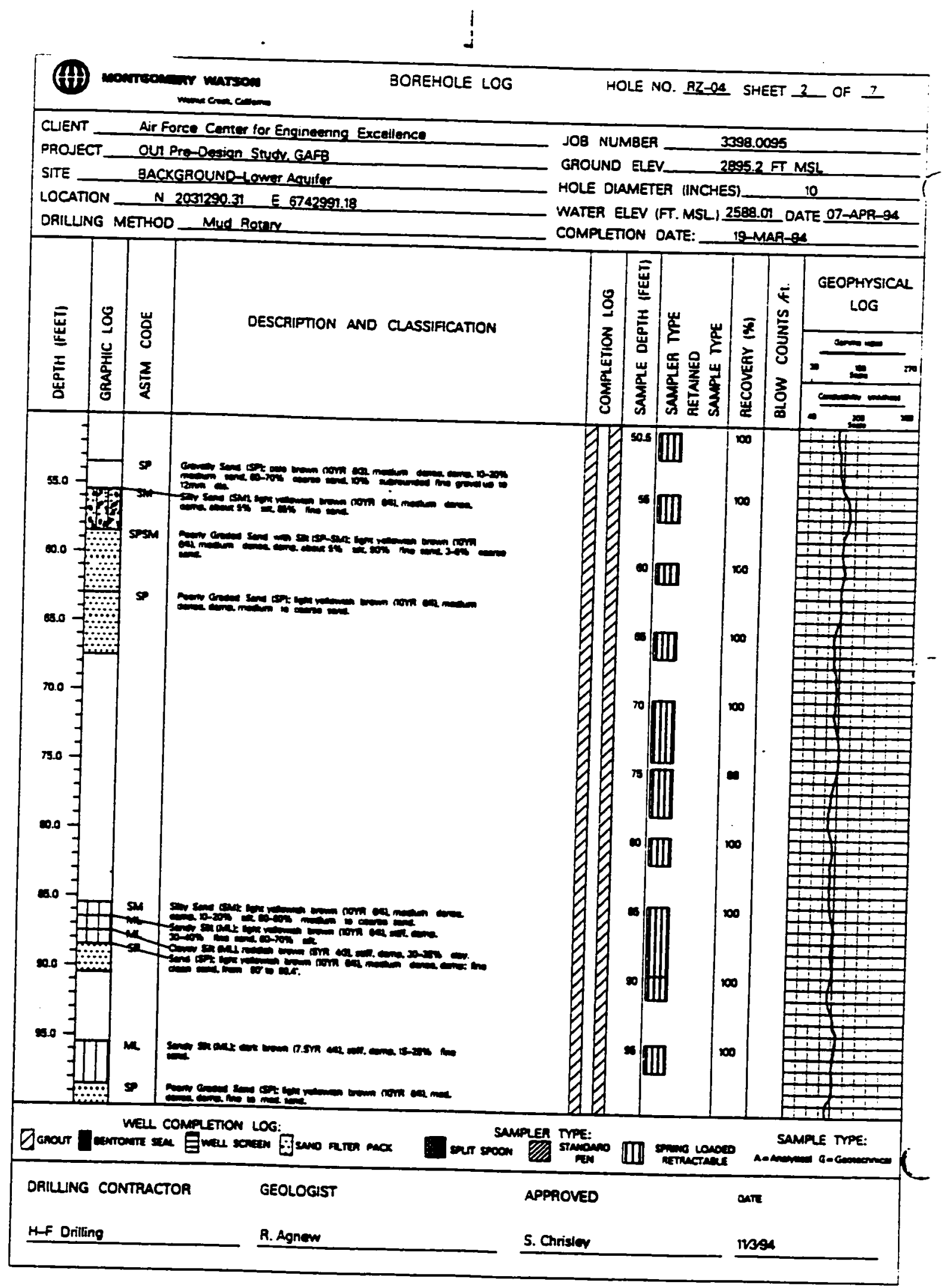




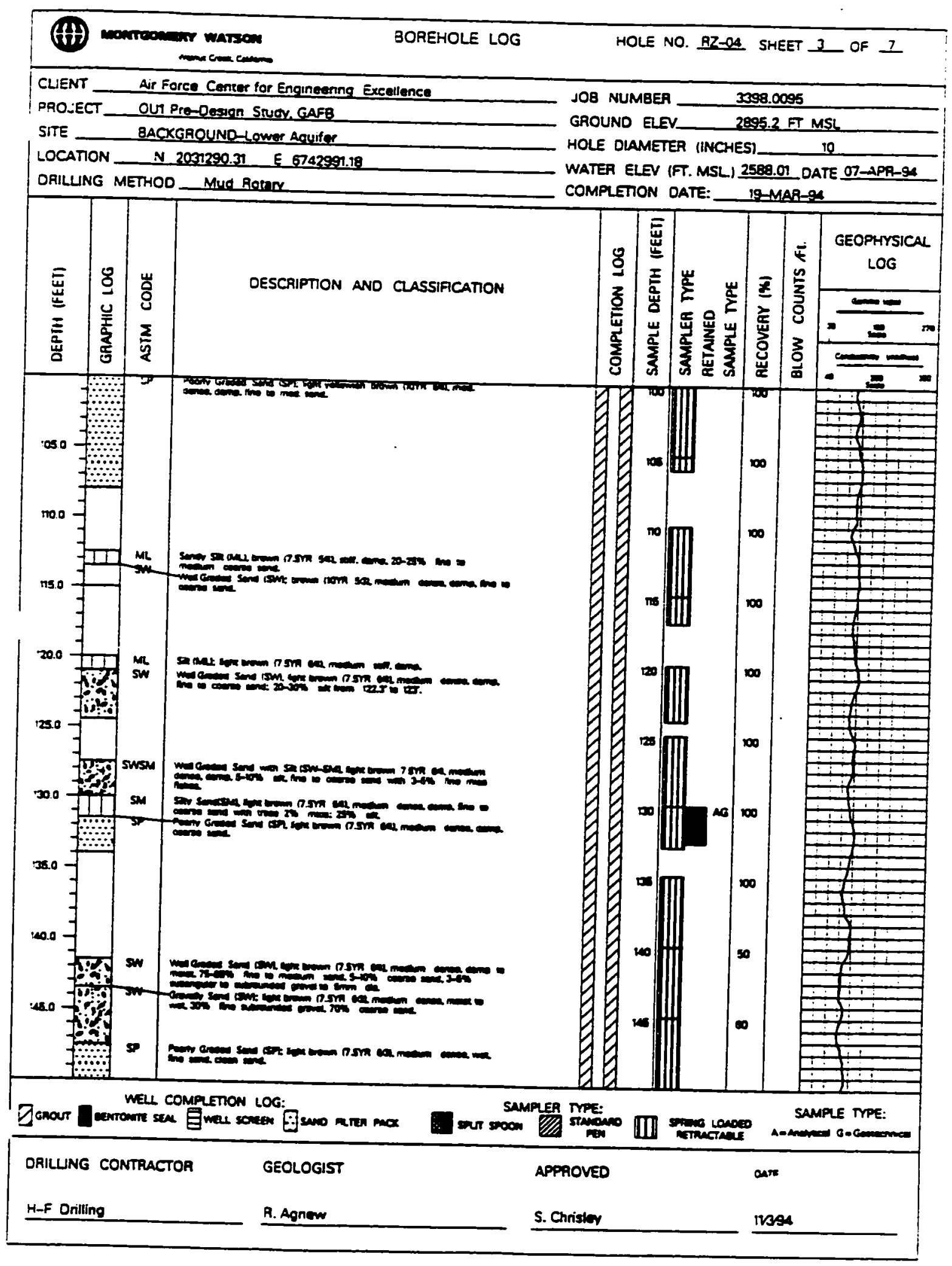




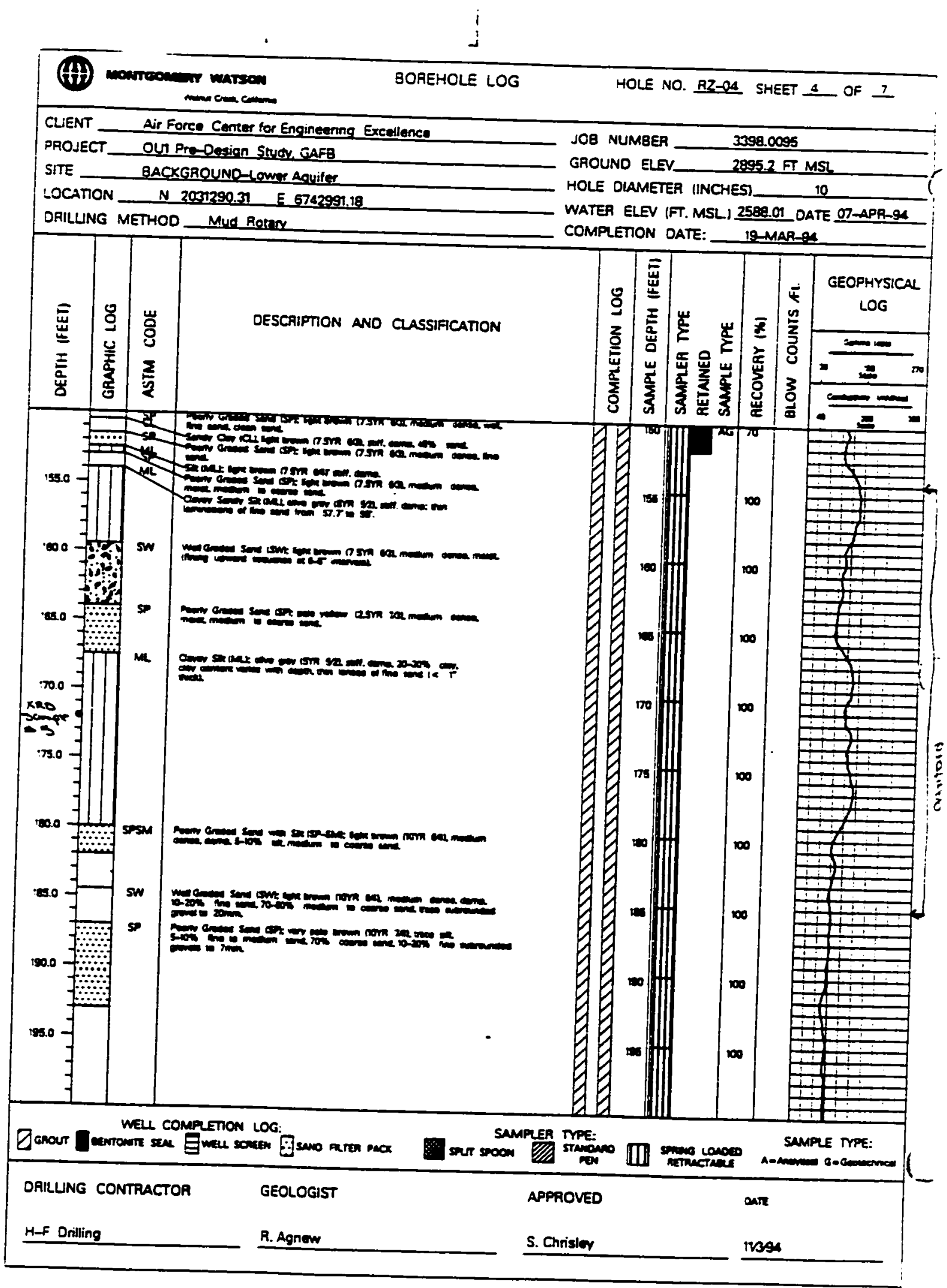




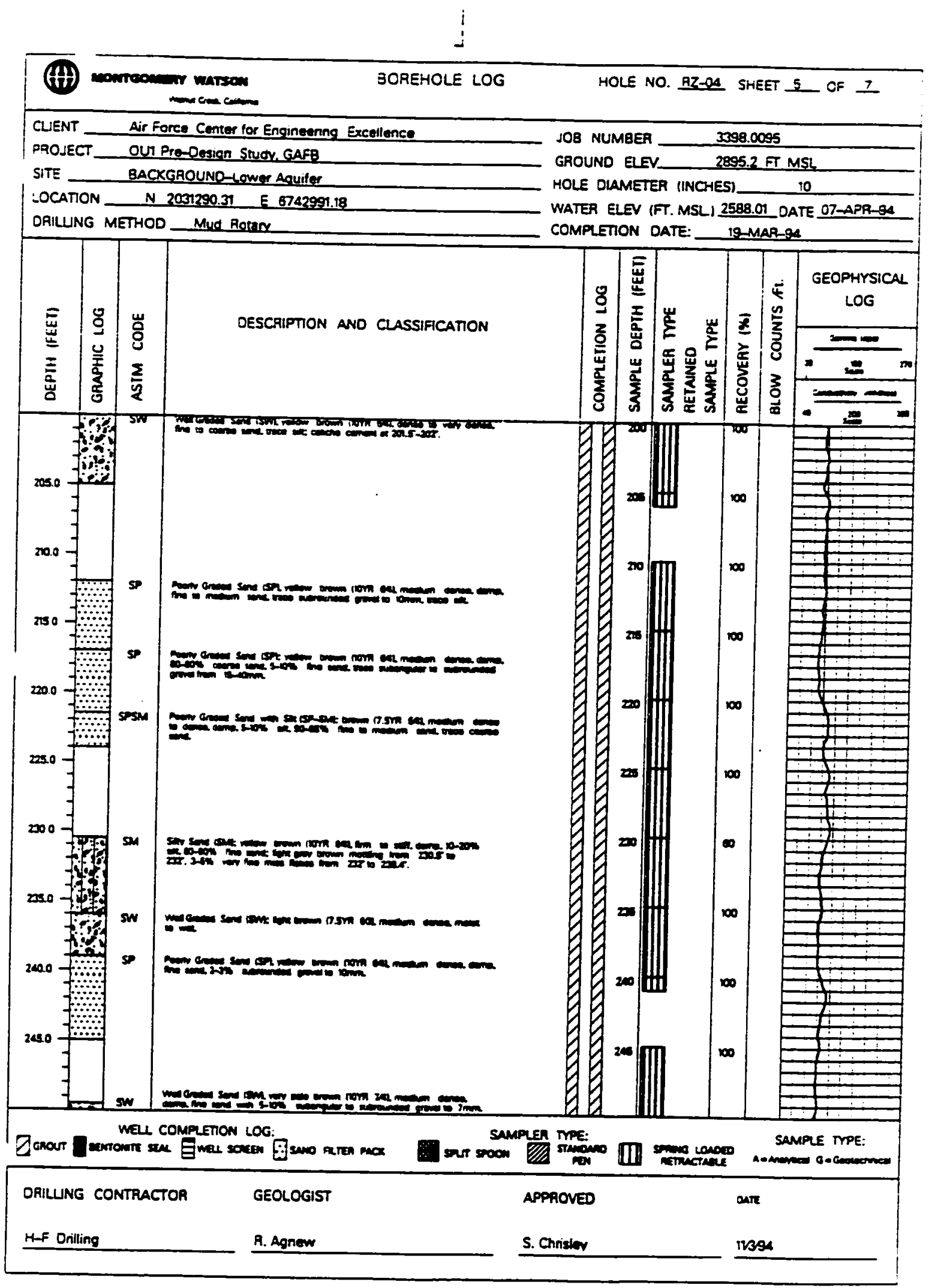




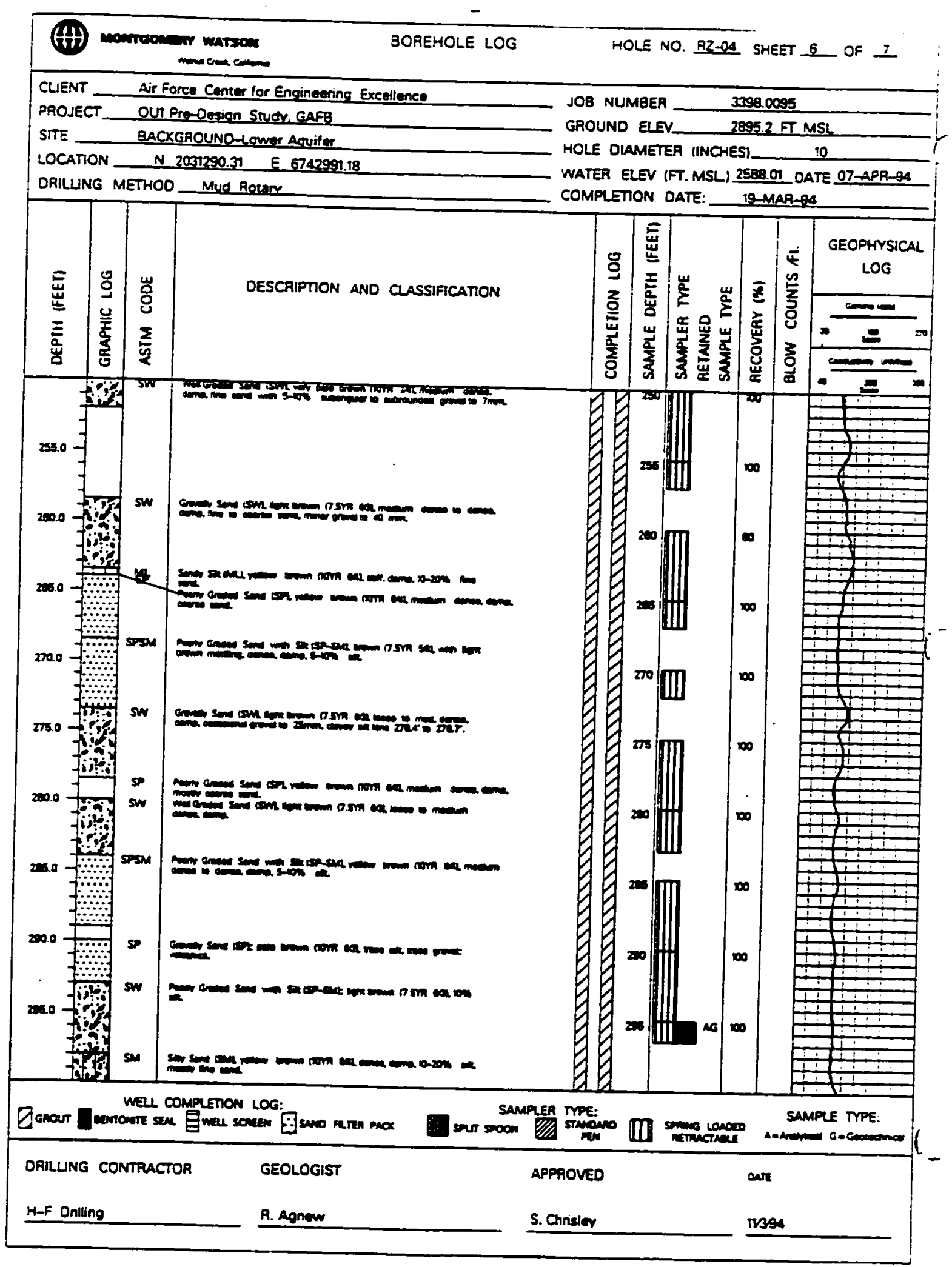




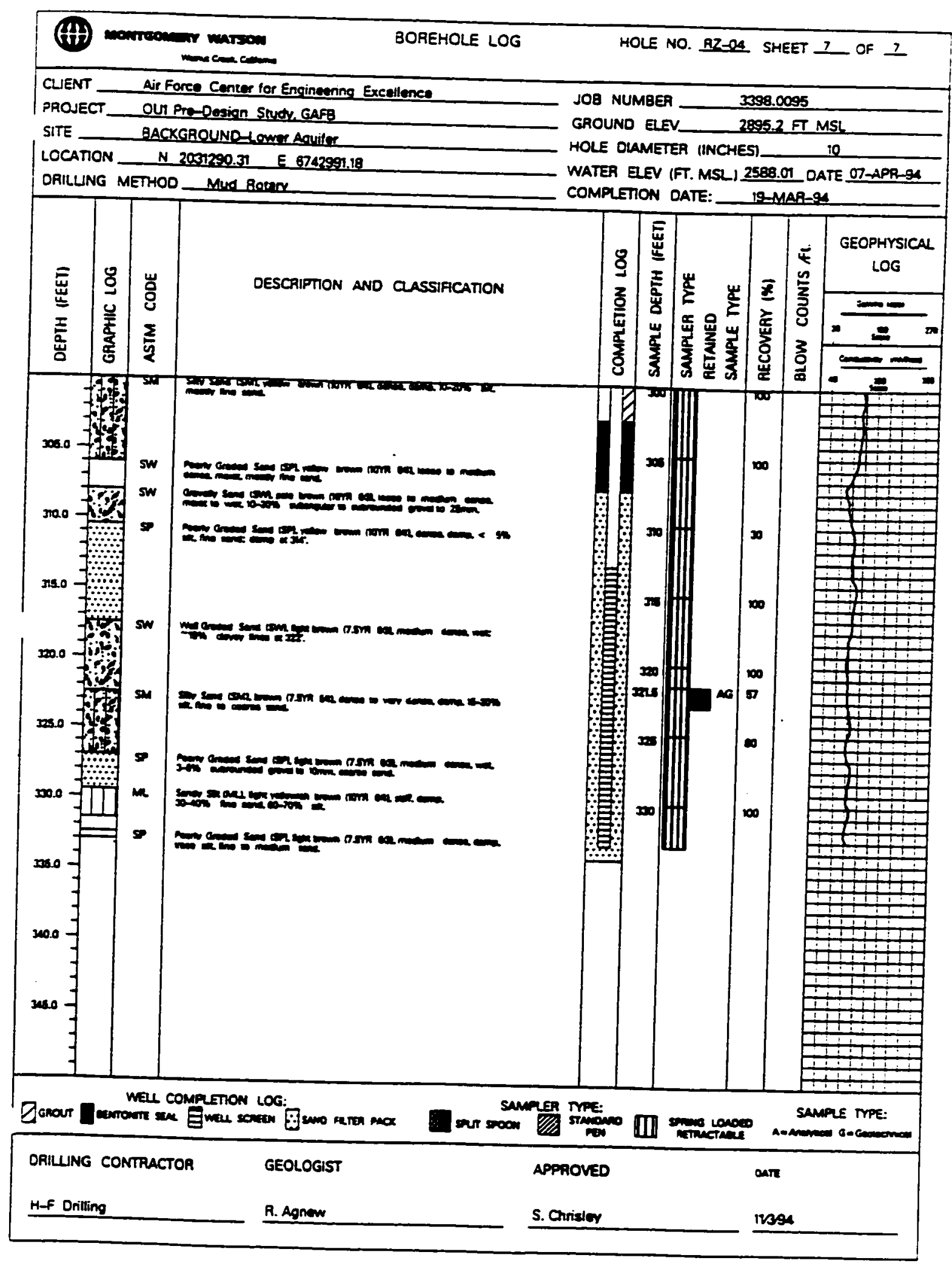


Appendix B

X-Ray Diffraction Graphs 


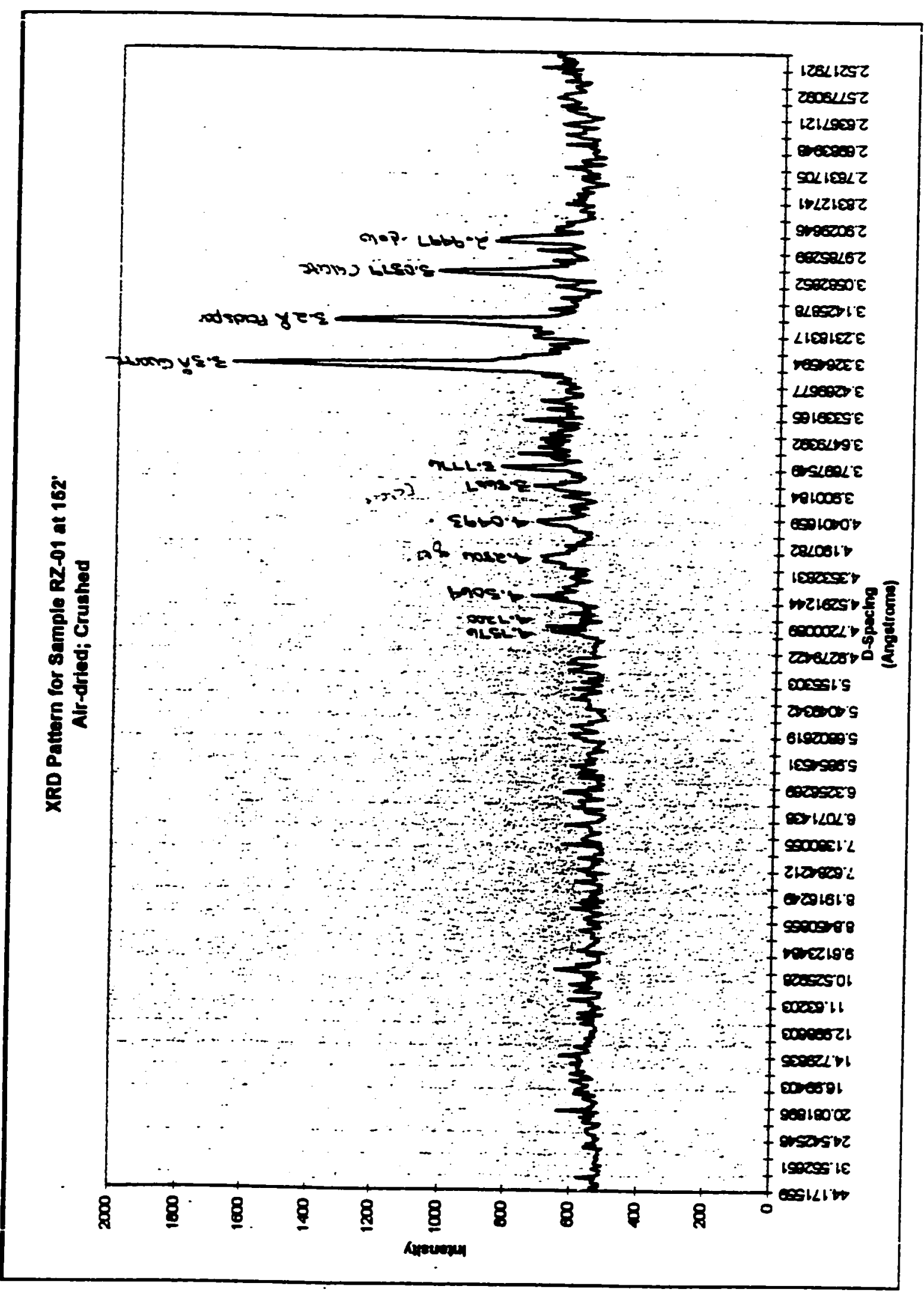




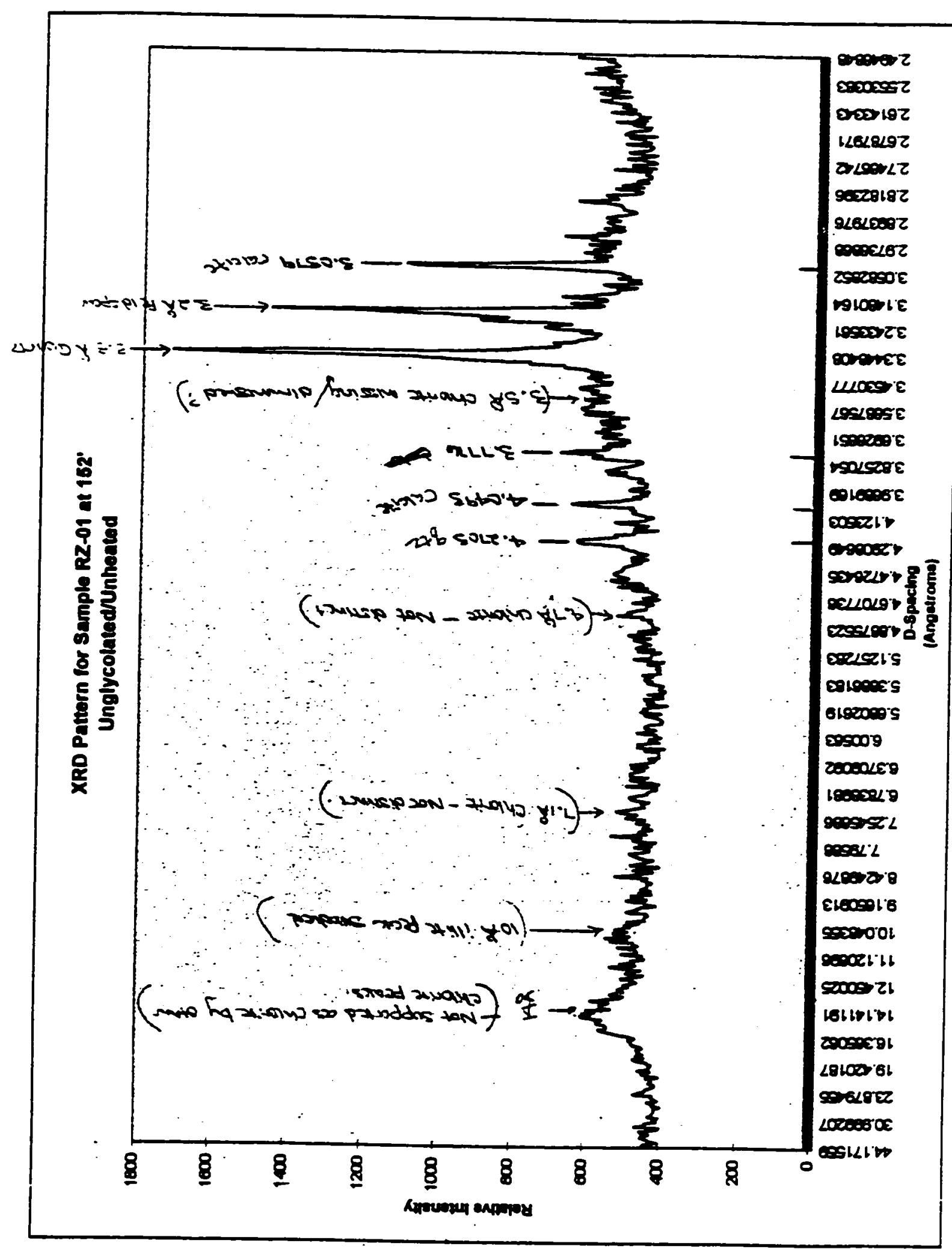




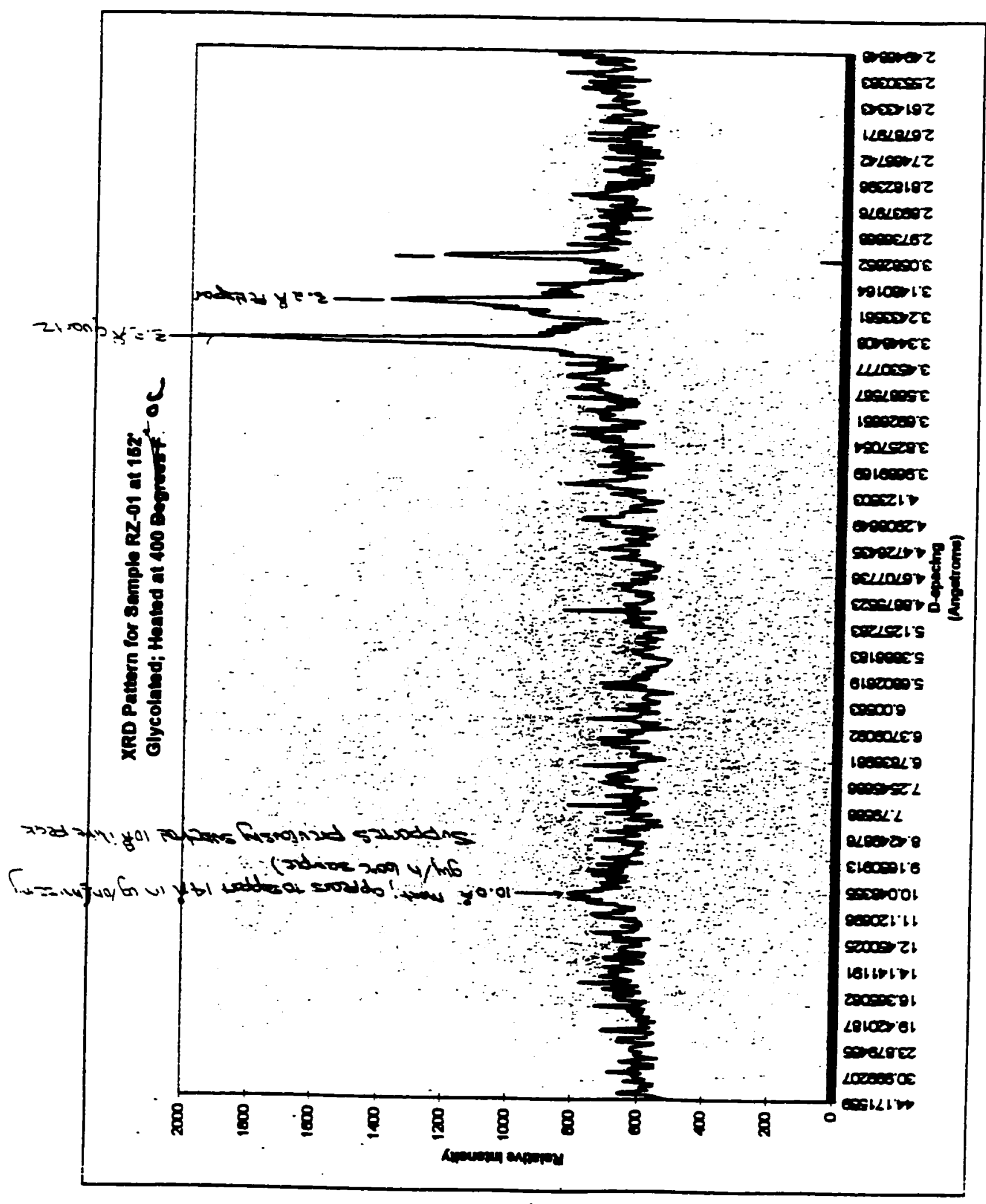




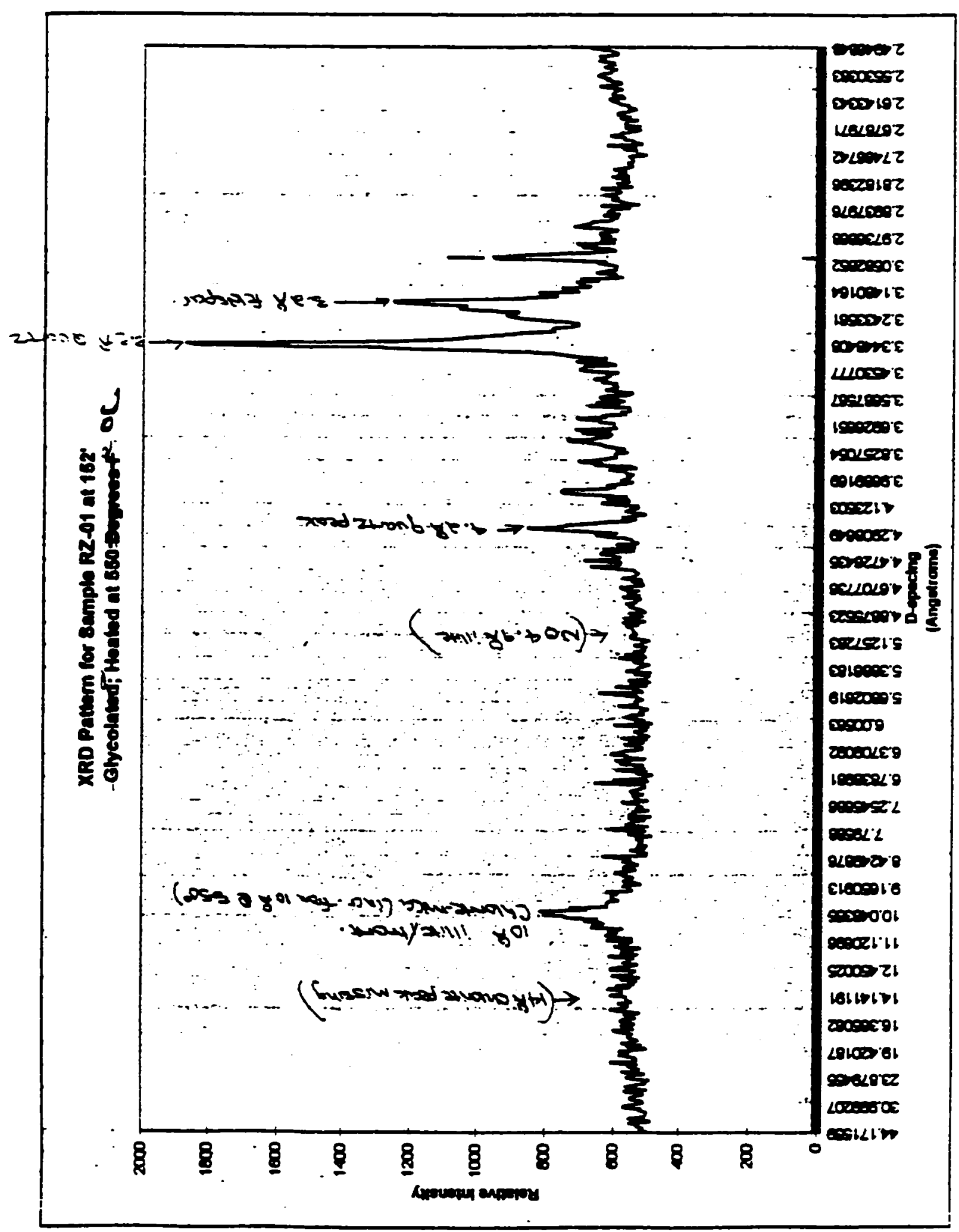




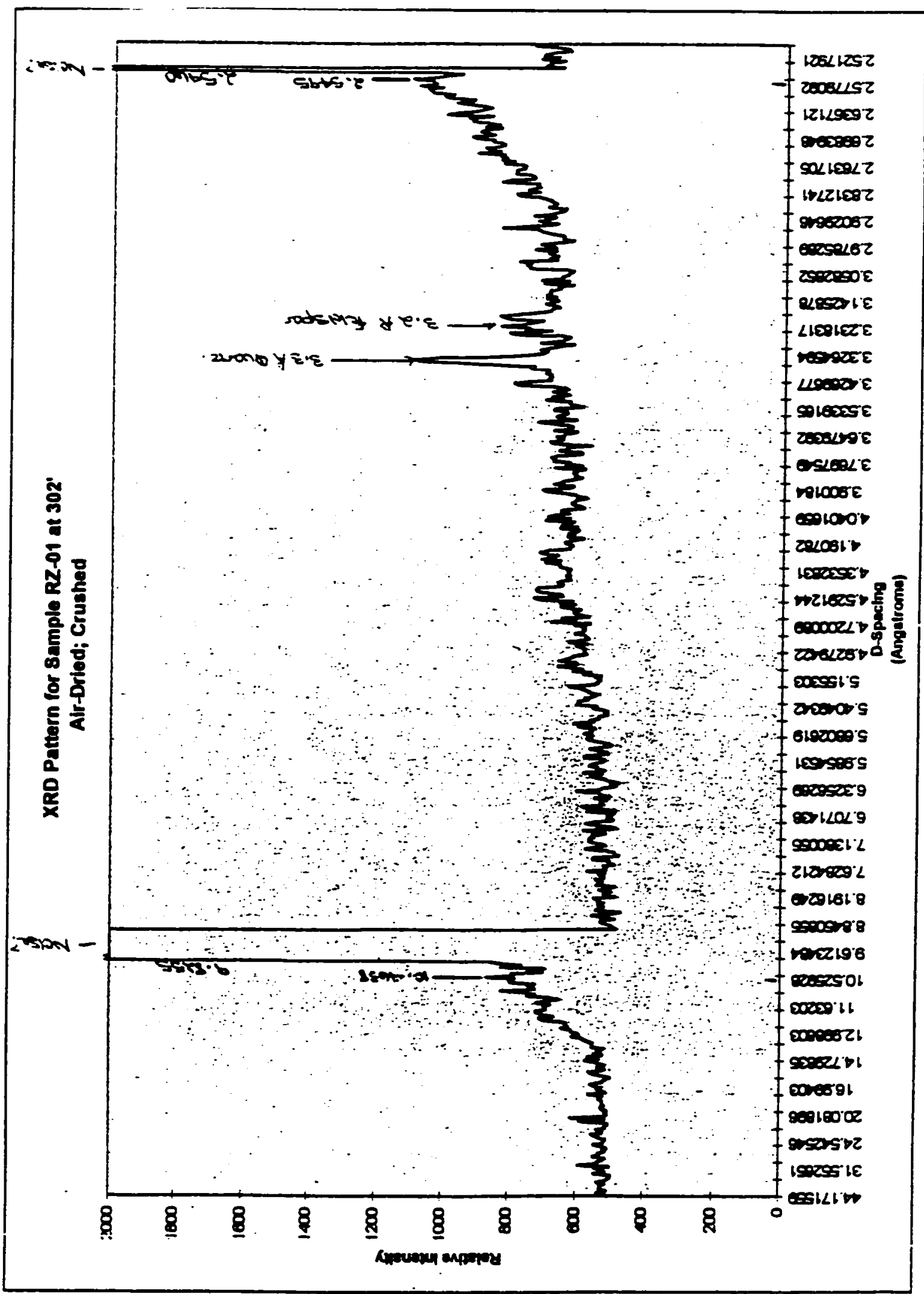




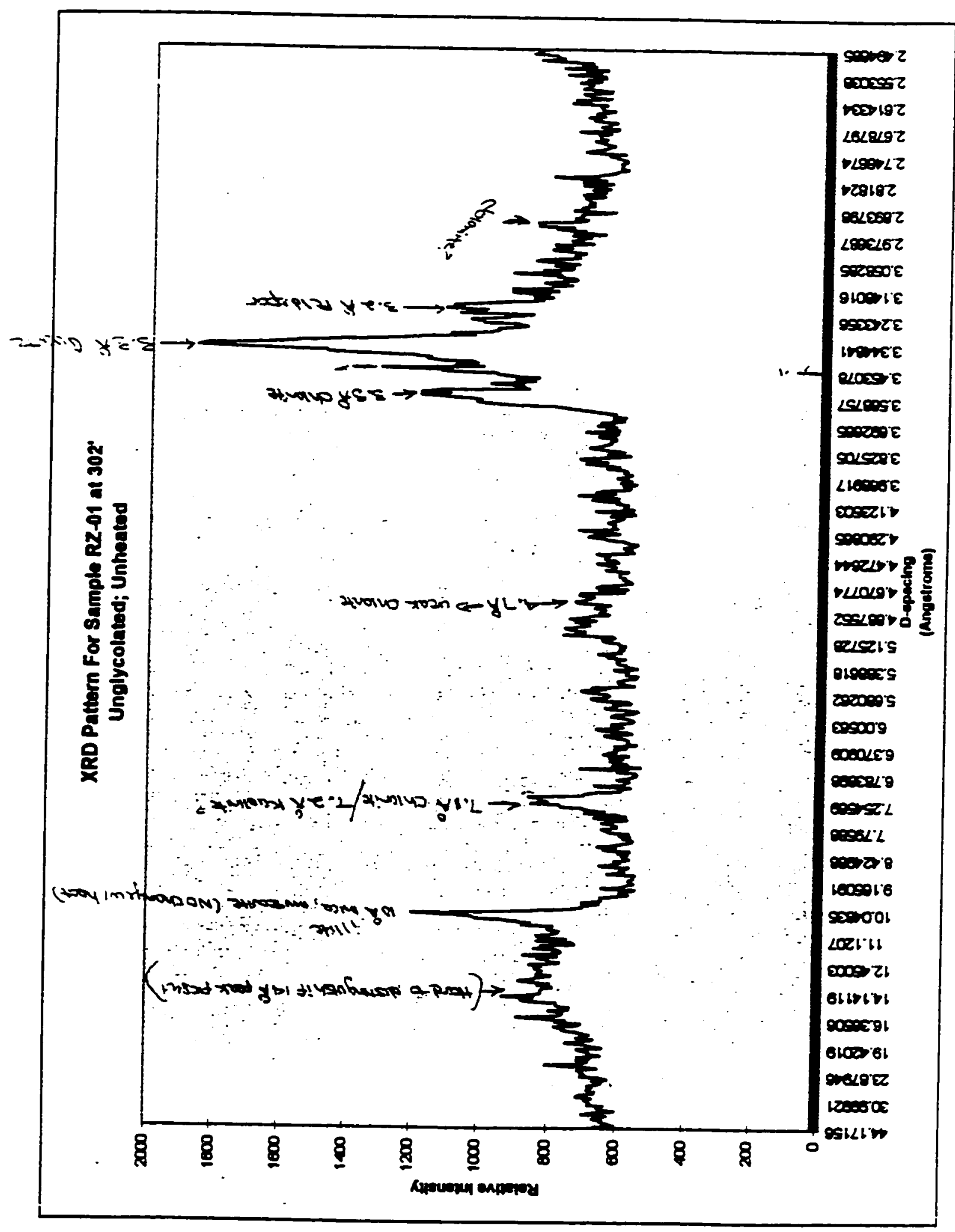




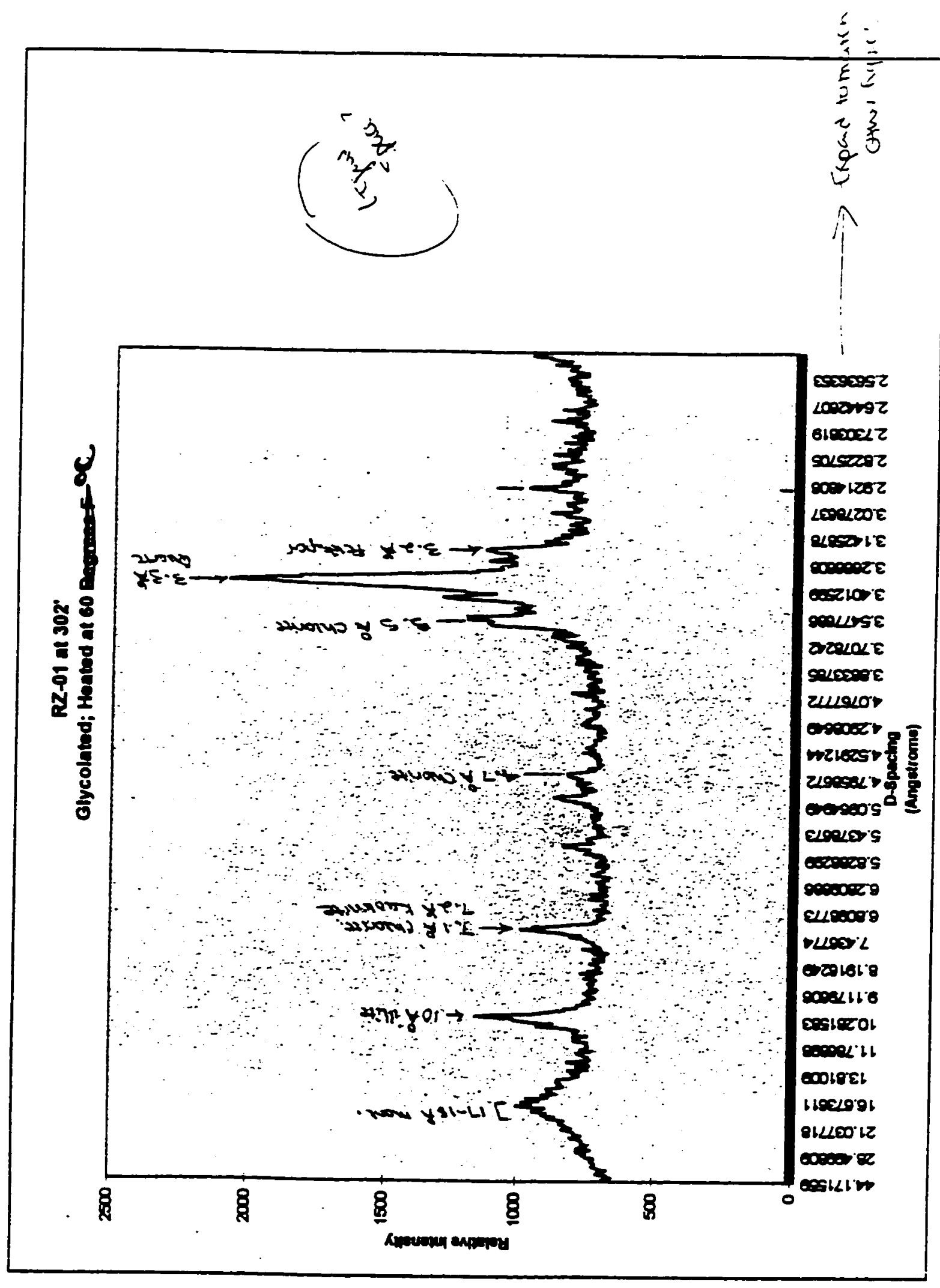




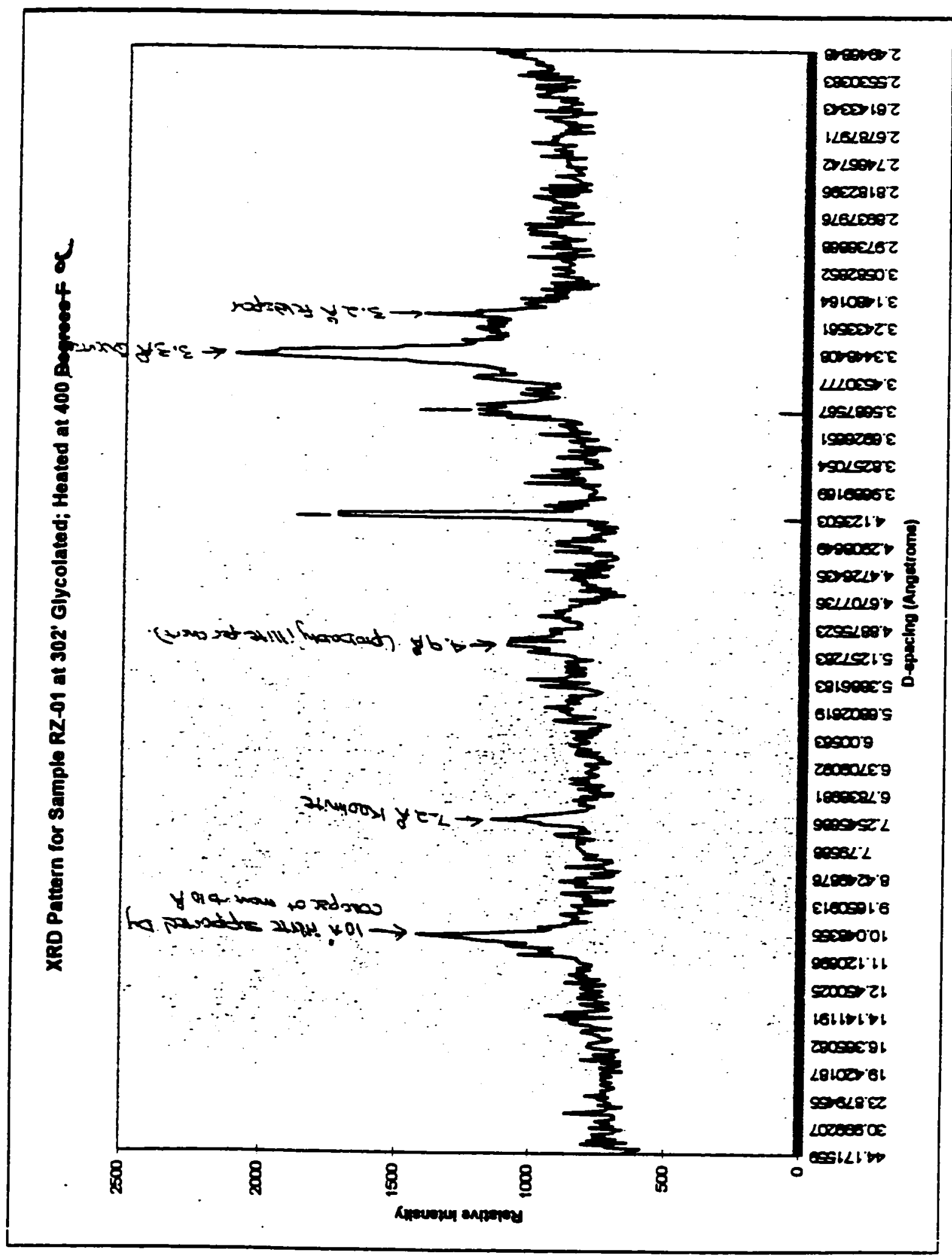




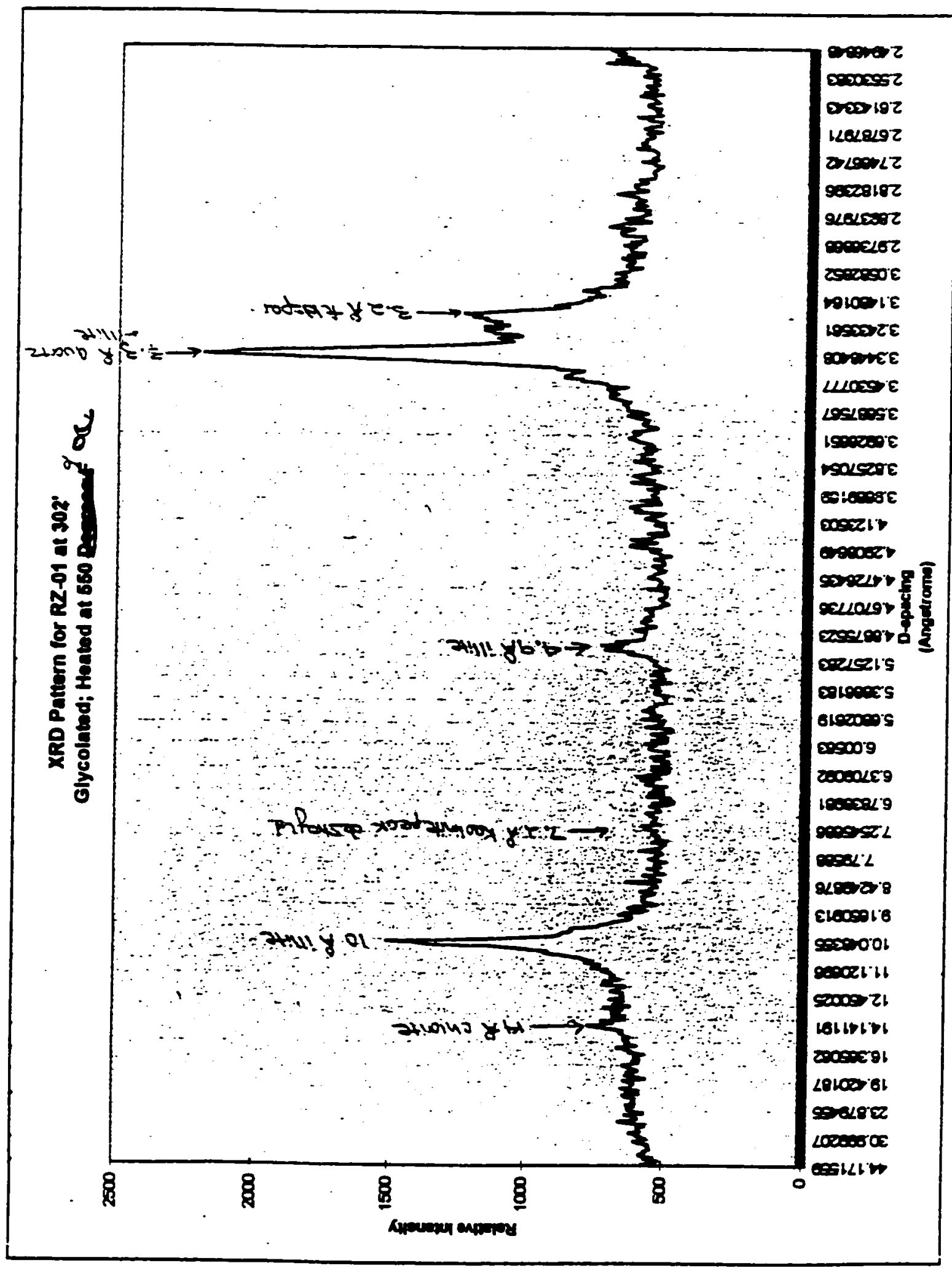




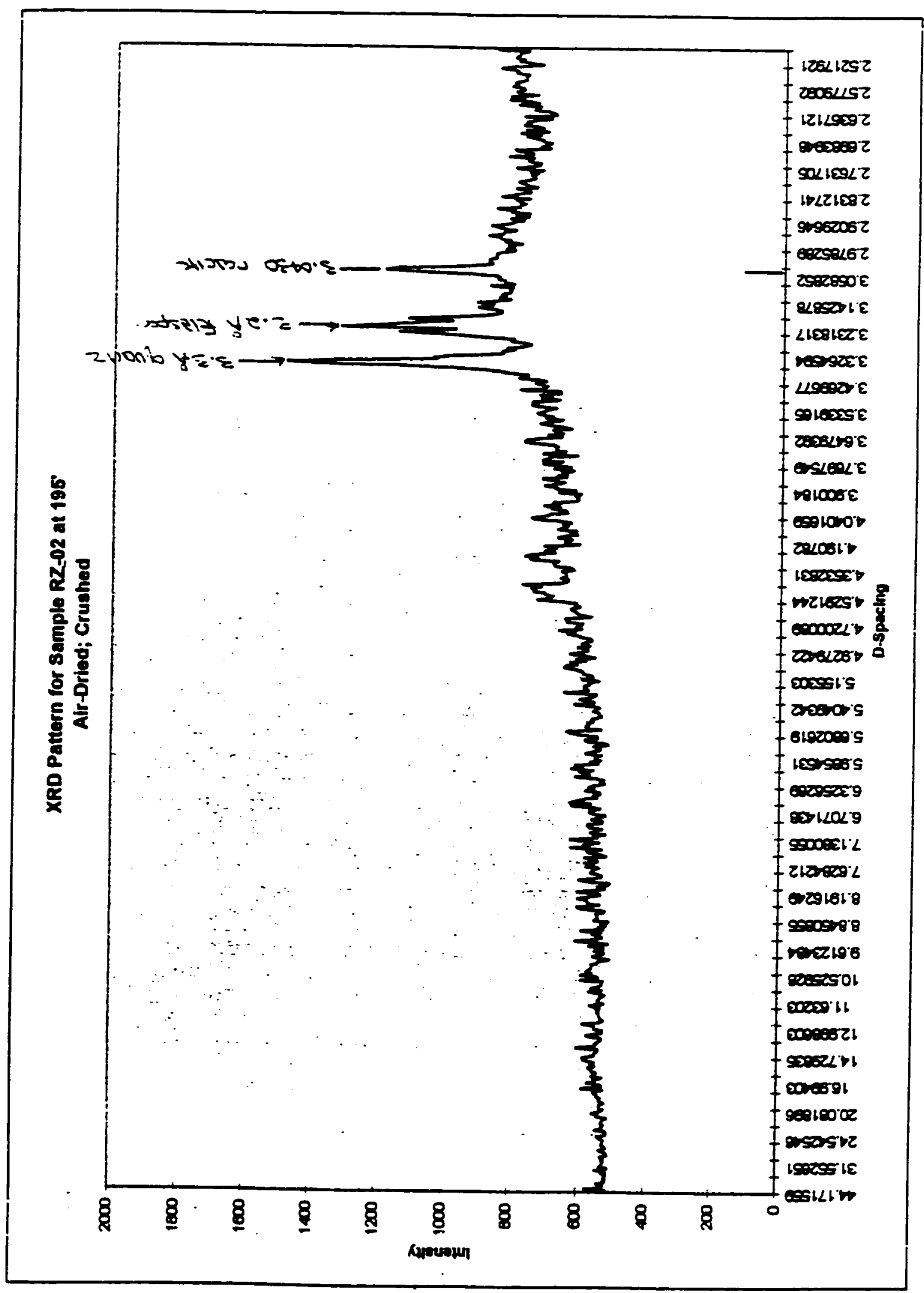




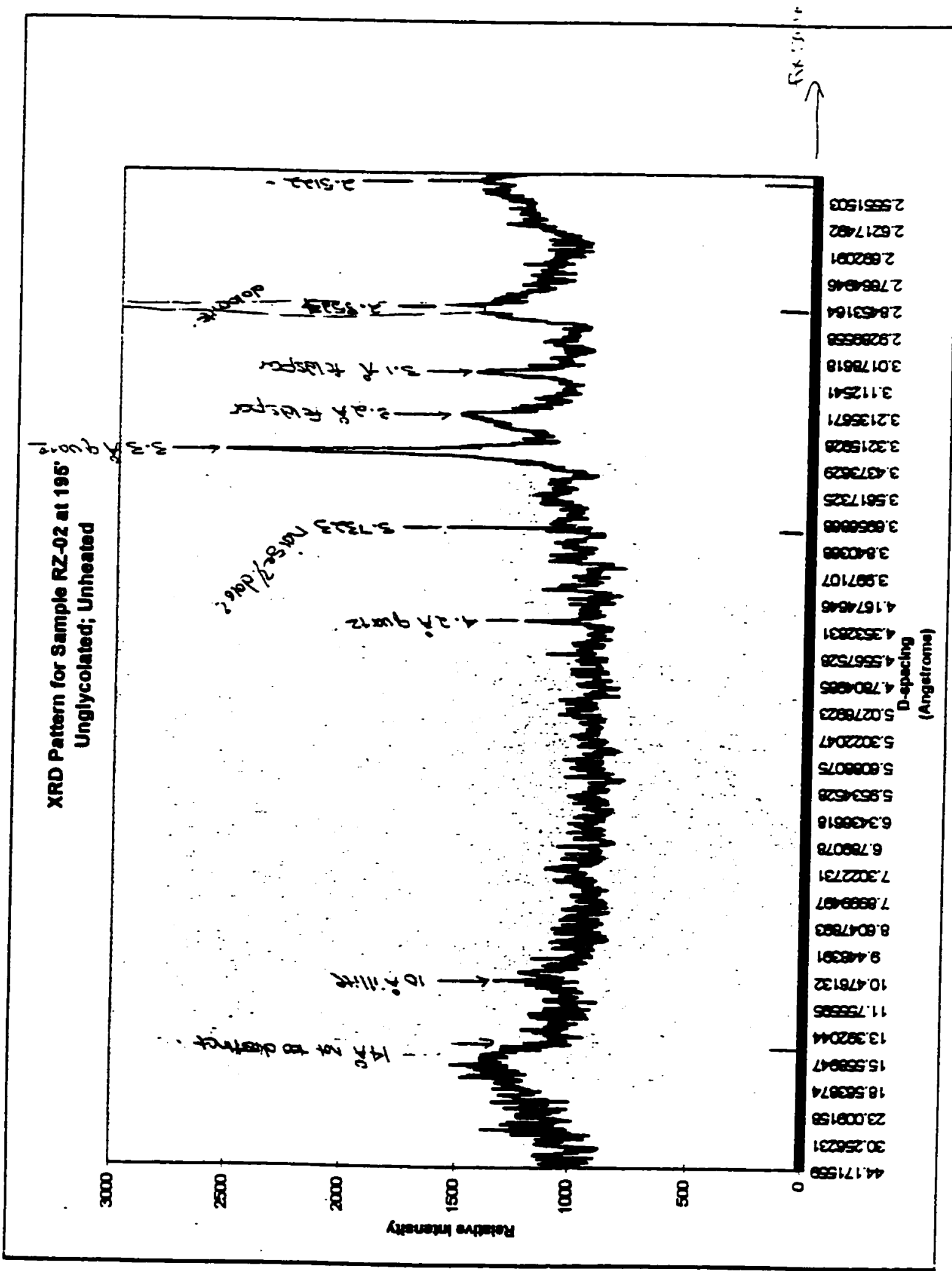




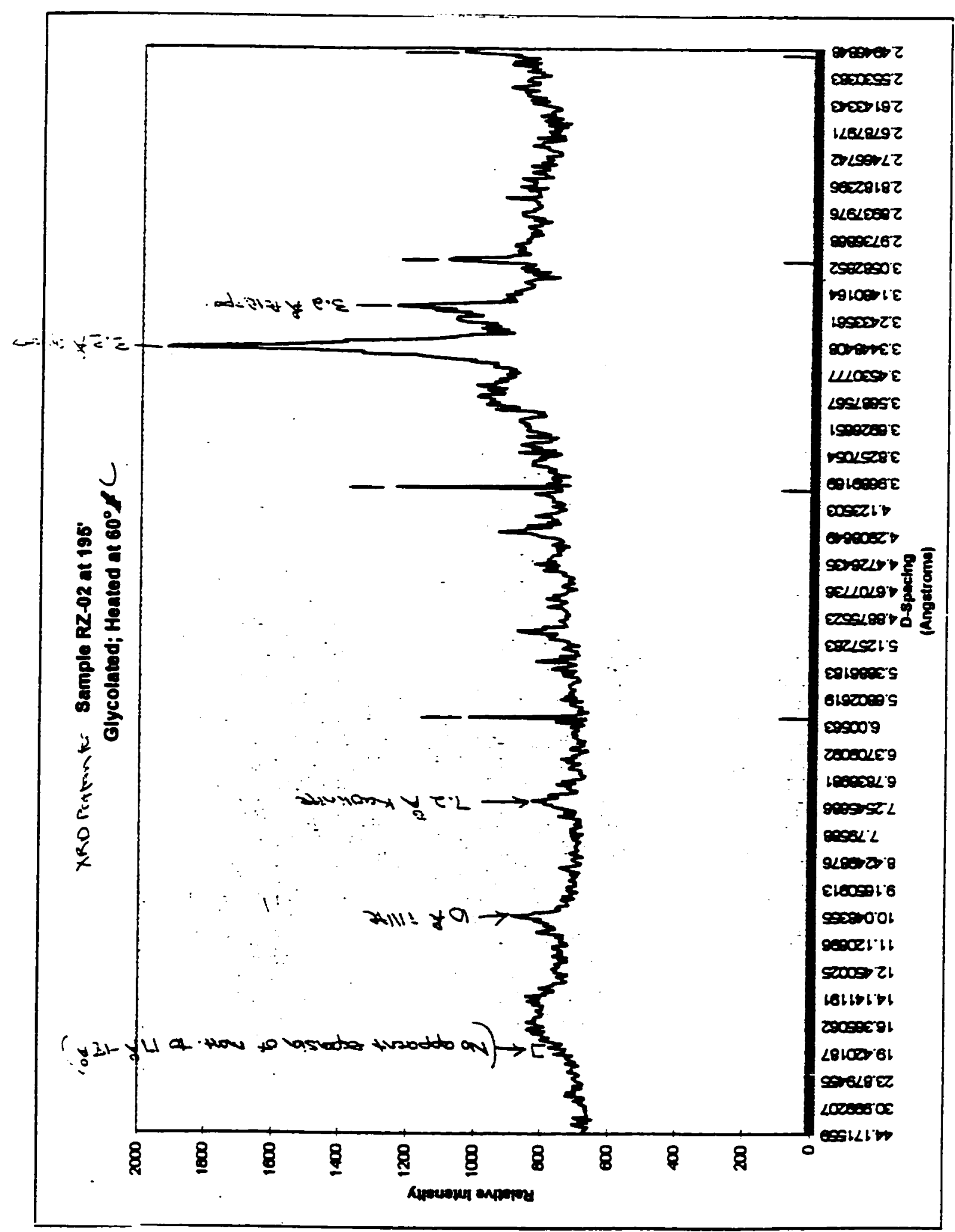




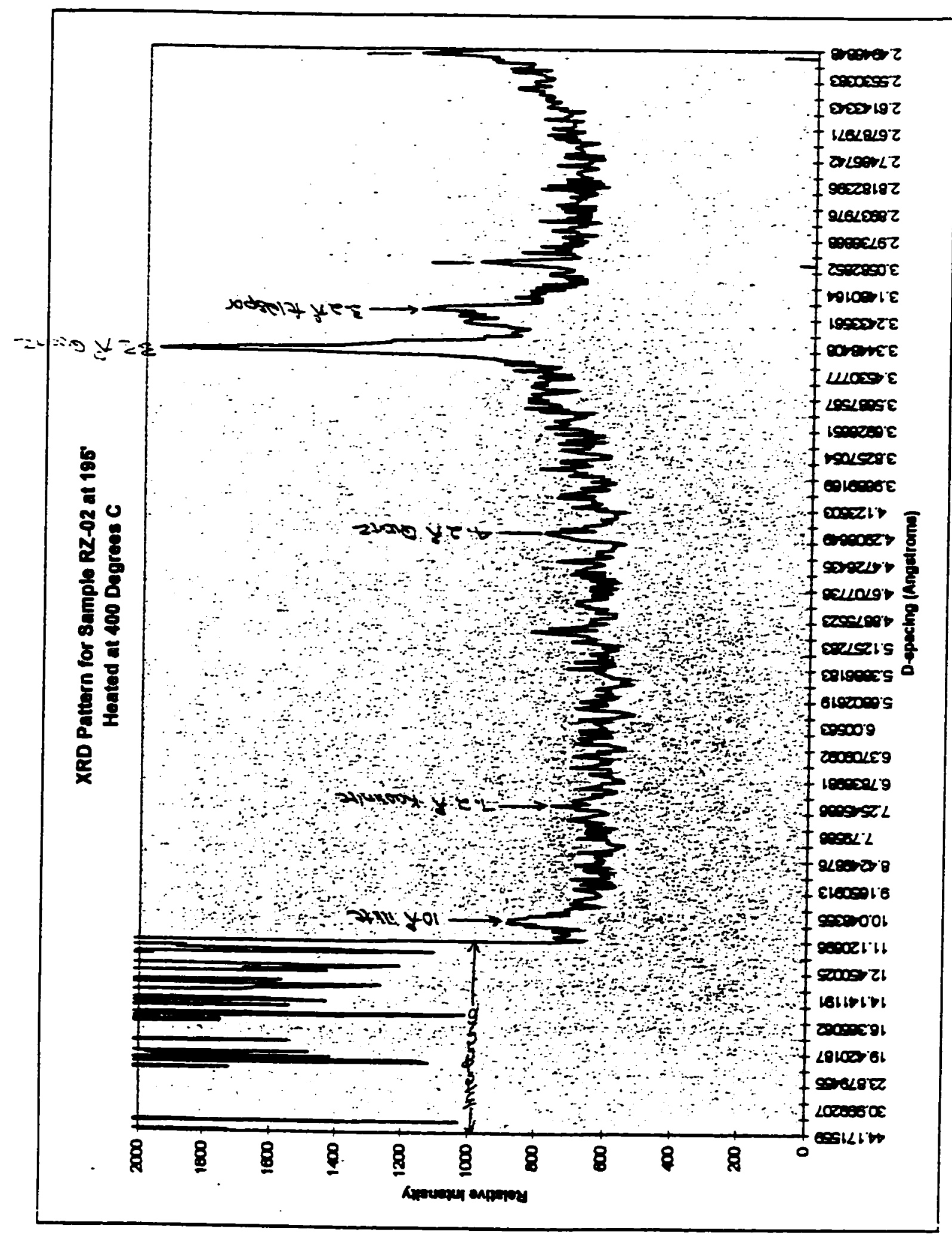




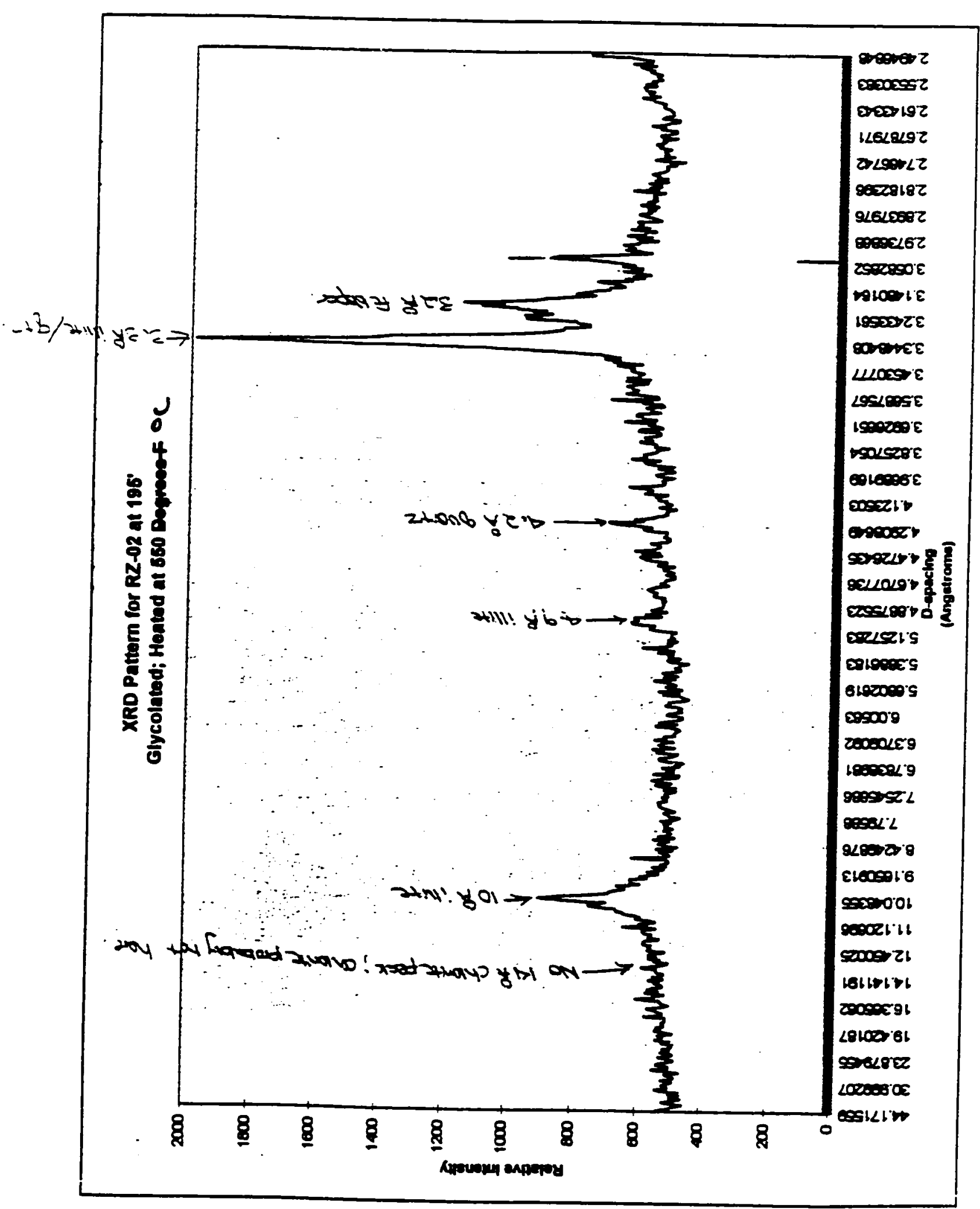




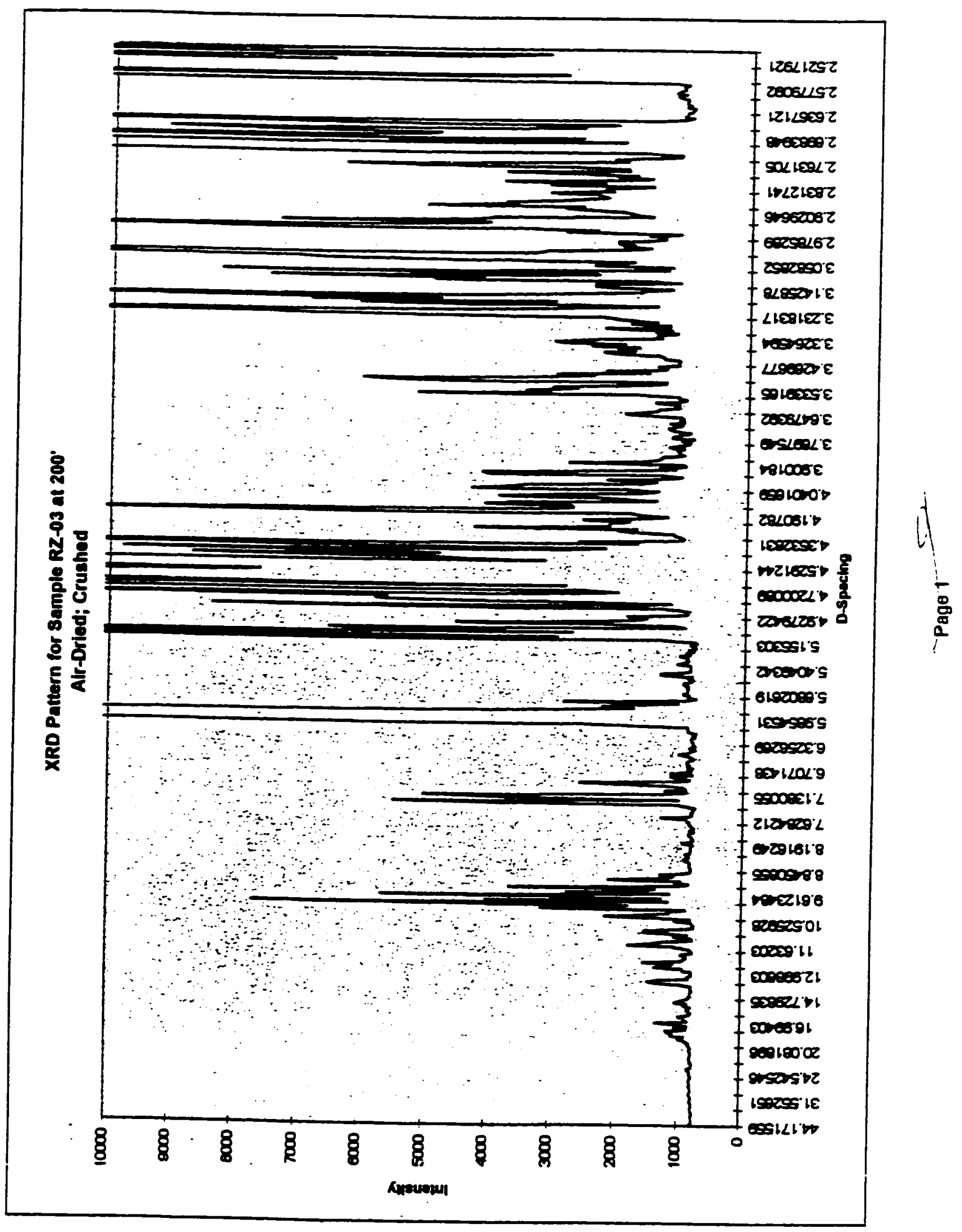




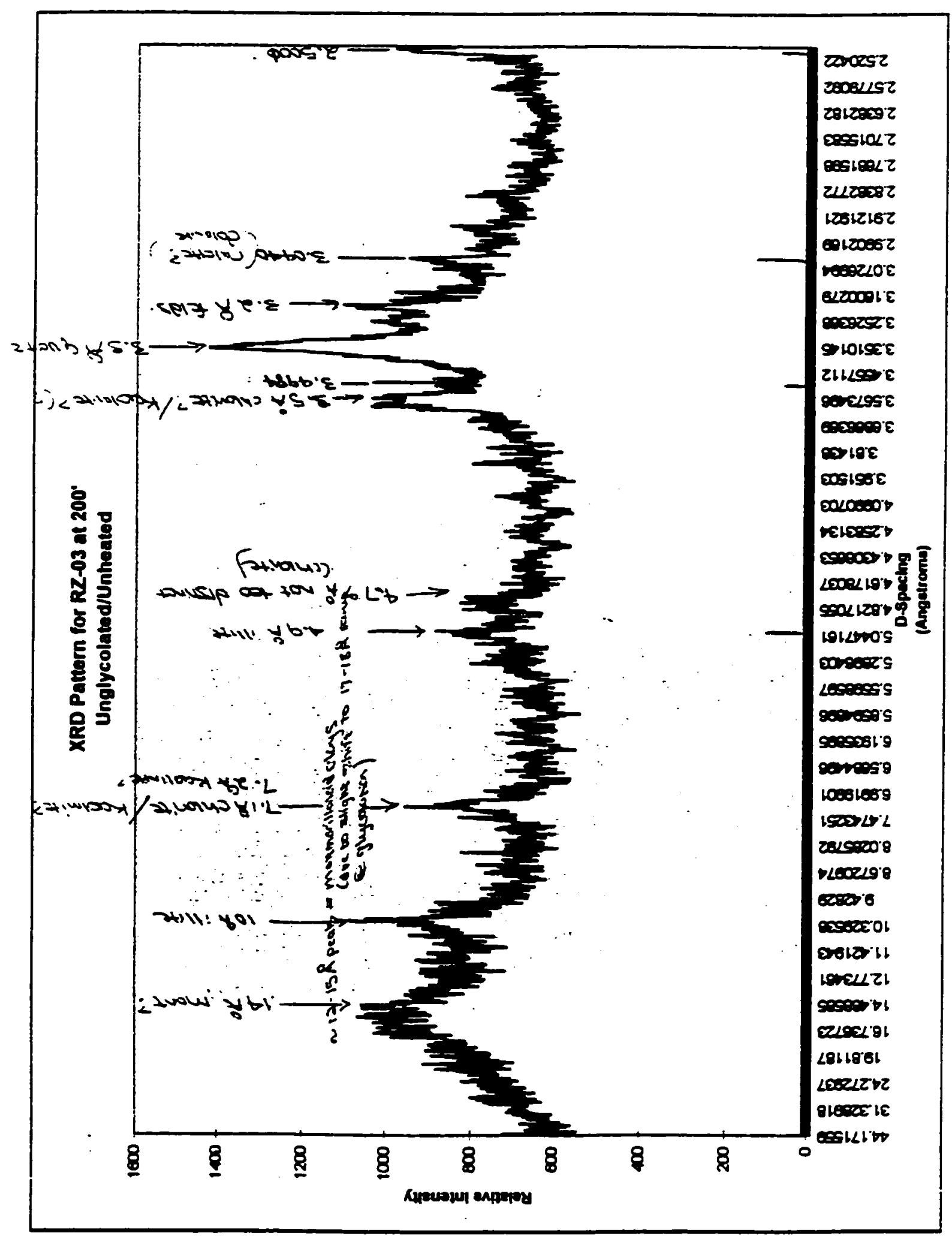




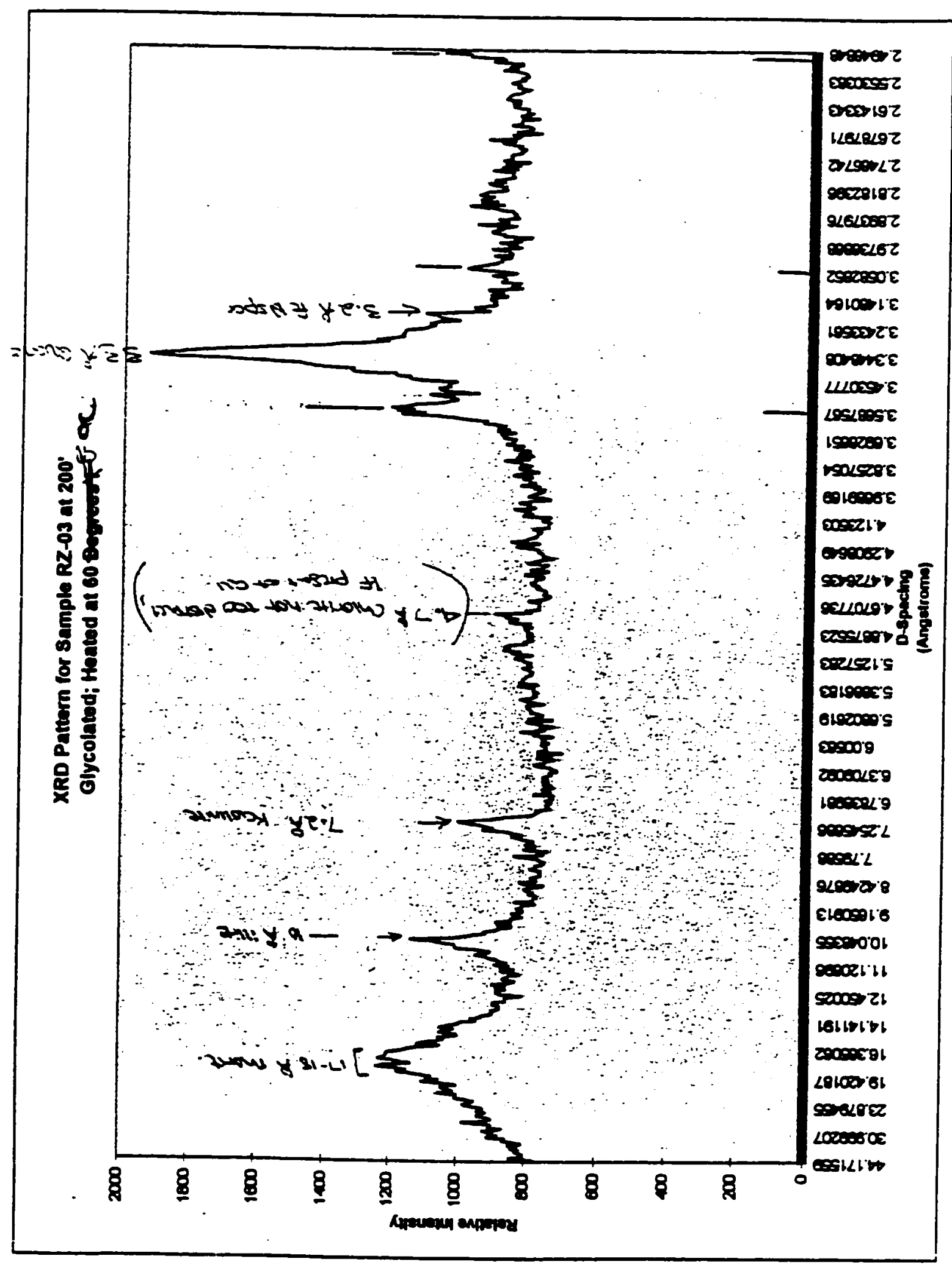




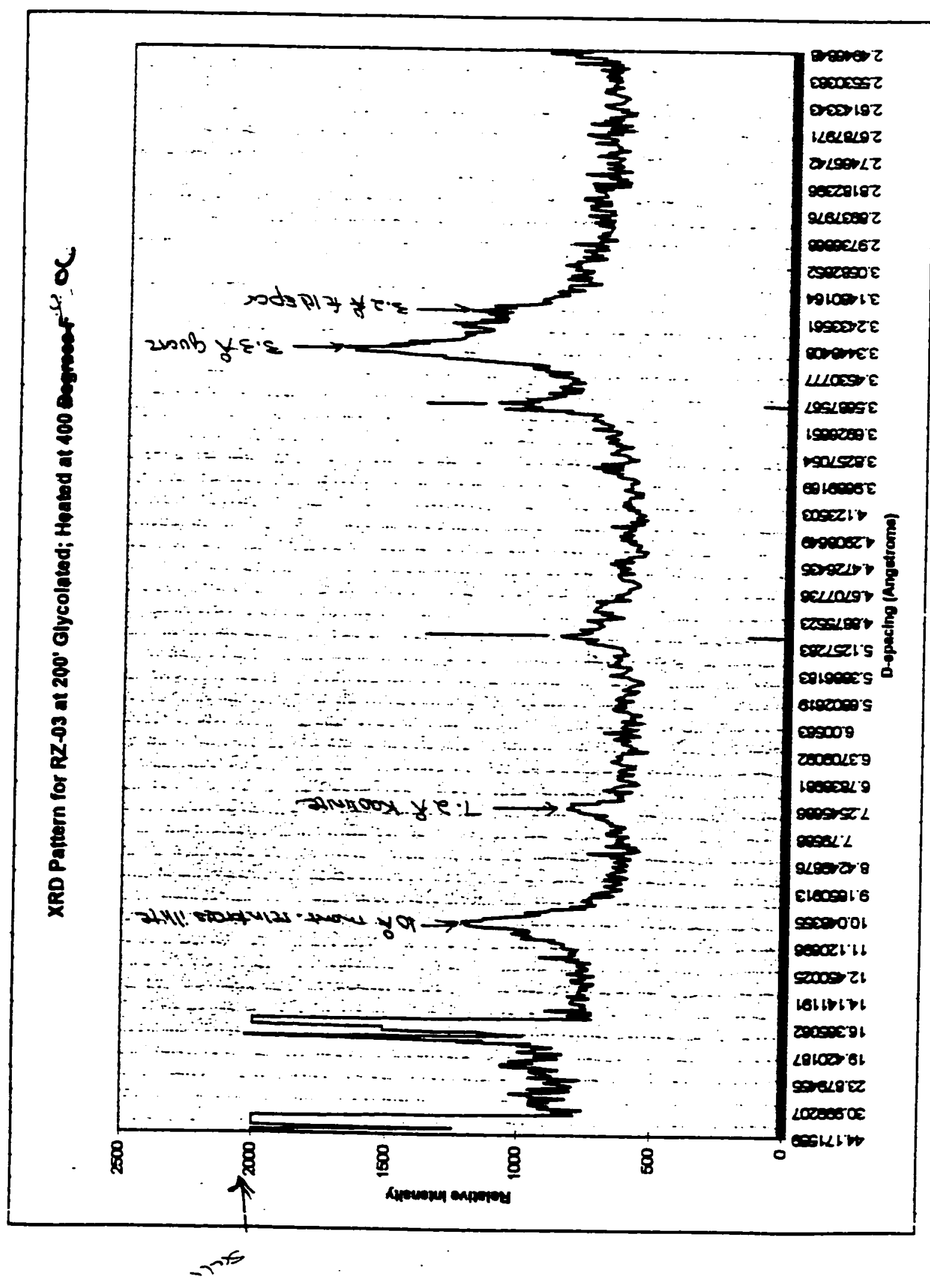




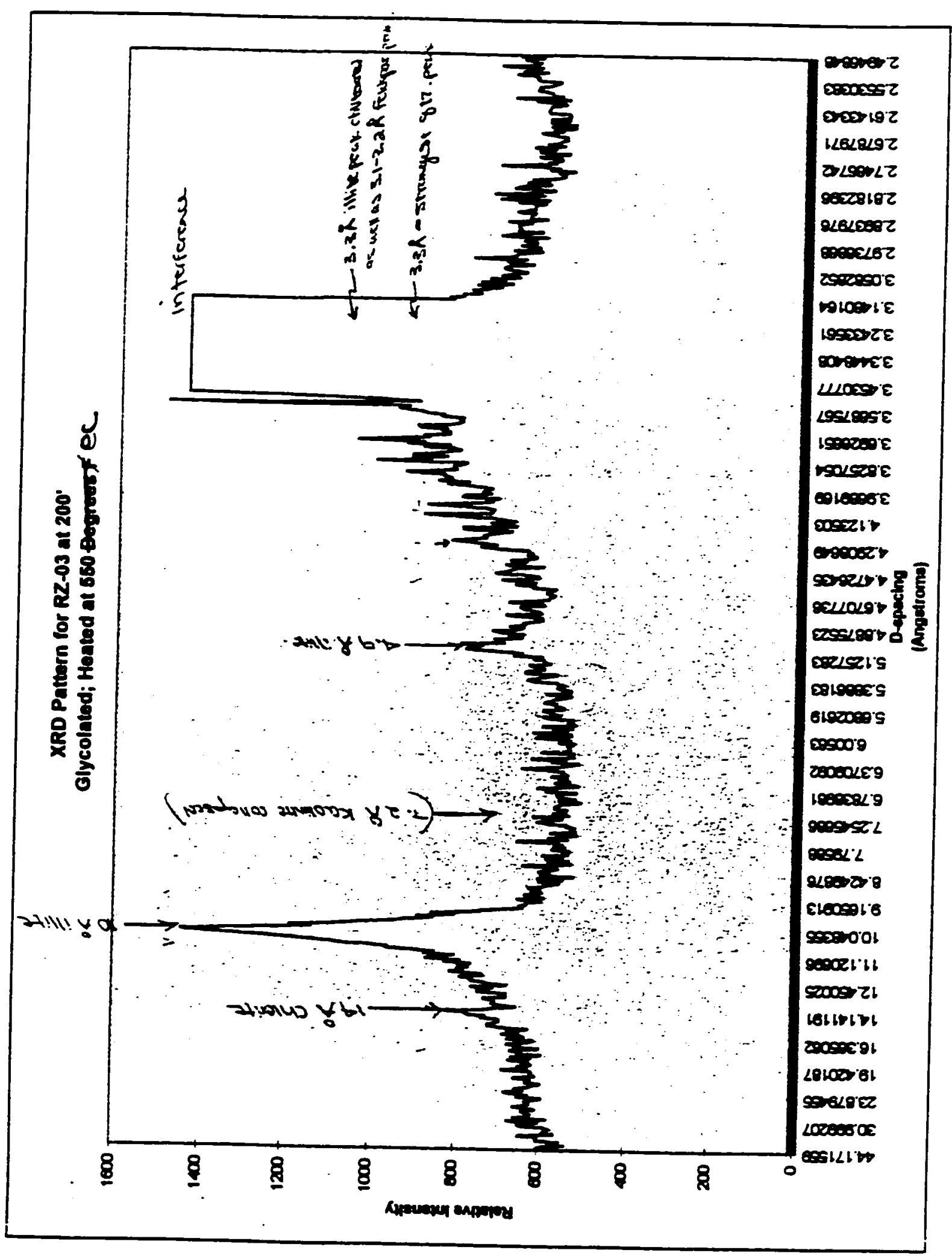




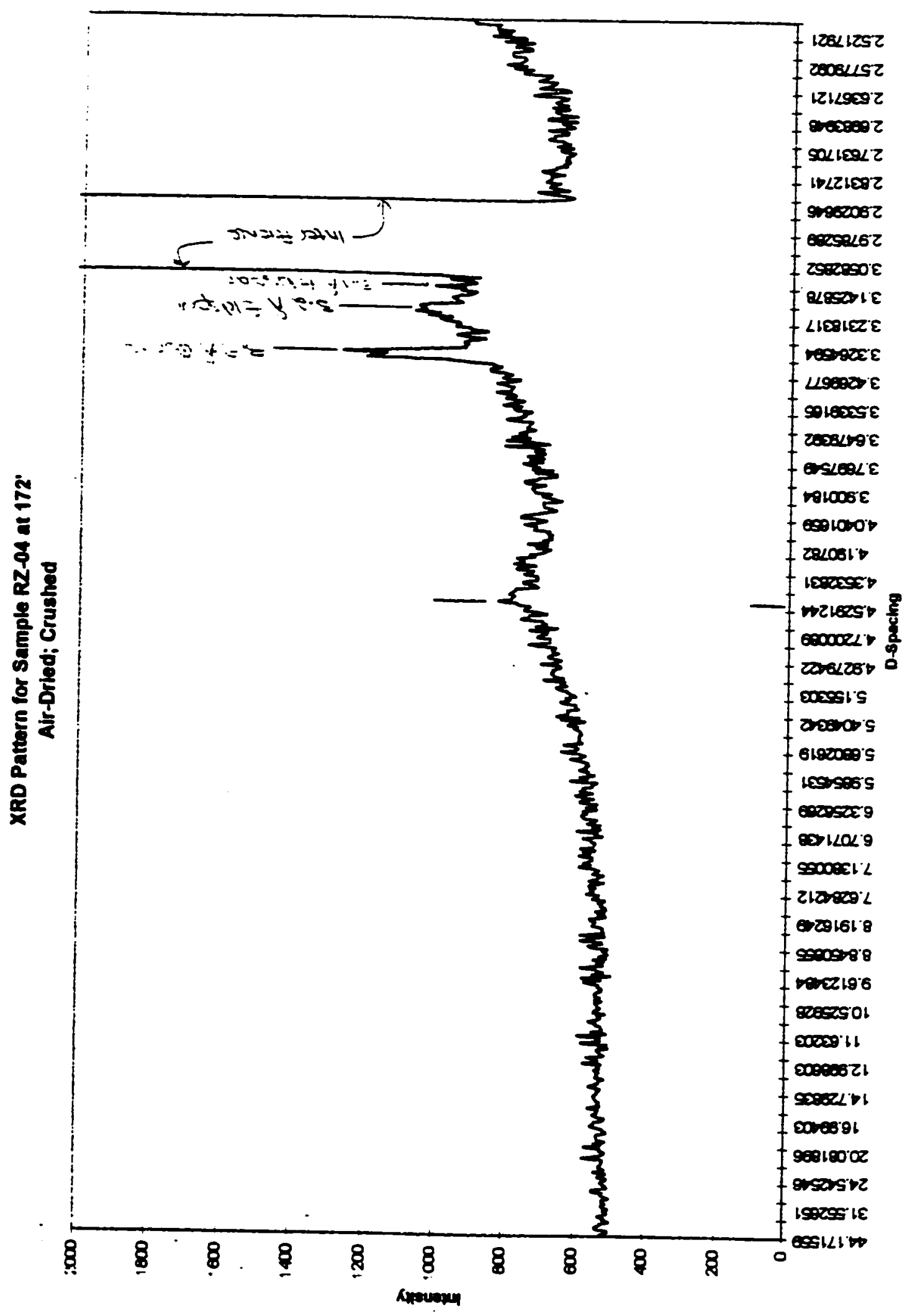

$\stackrel{-}{0}$ 


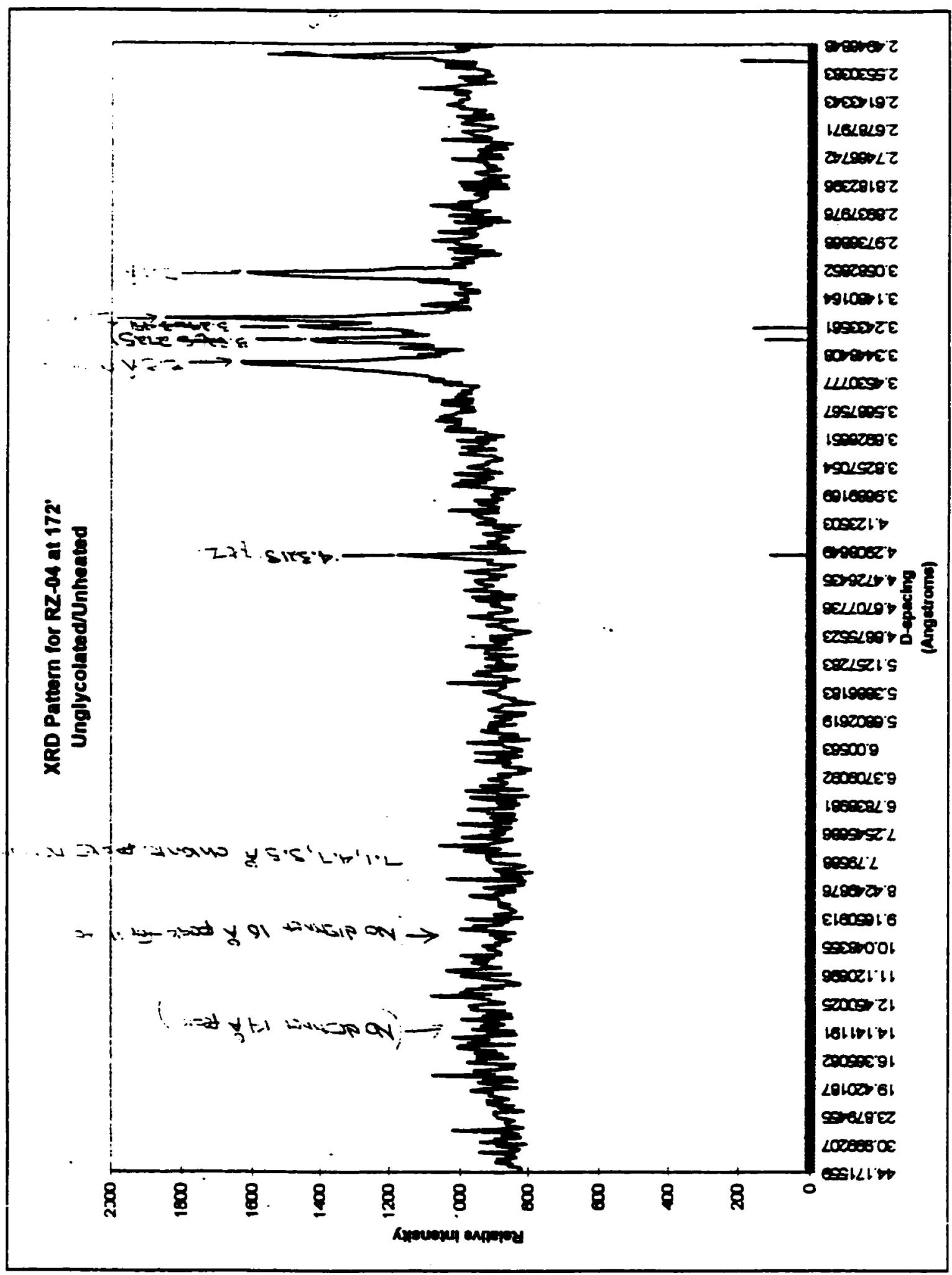




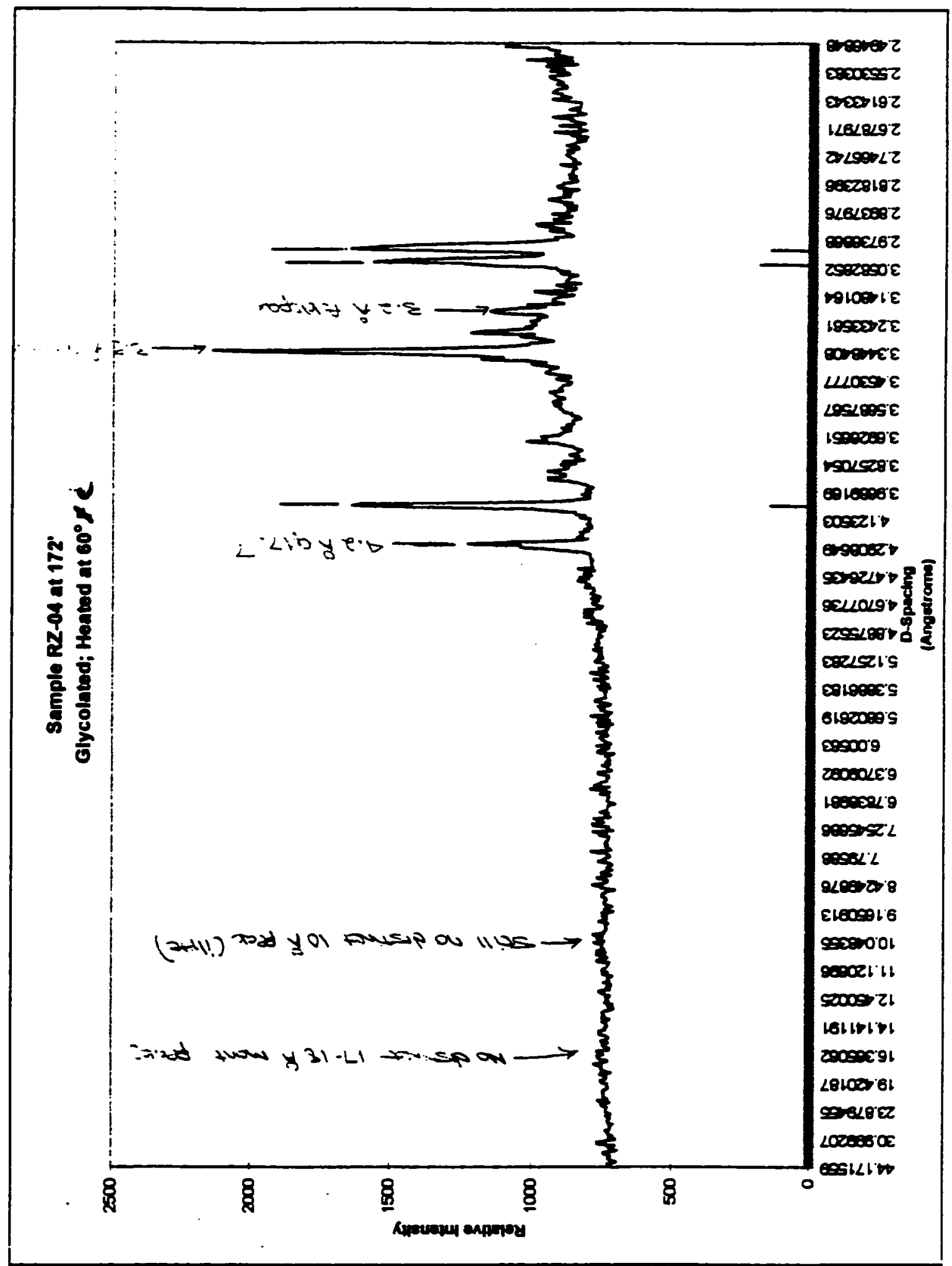




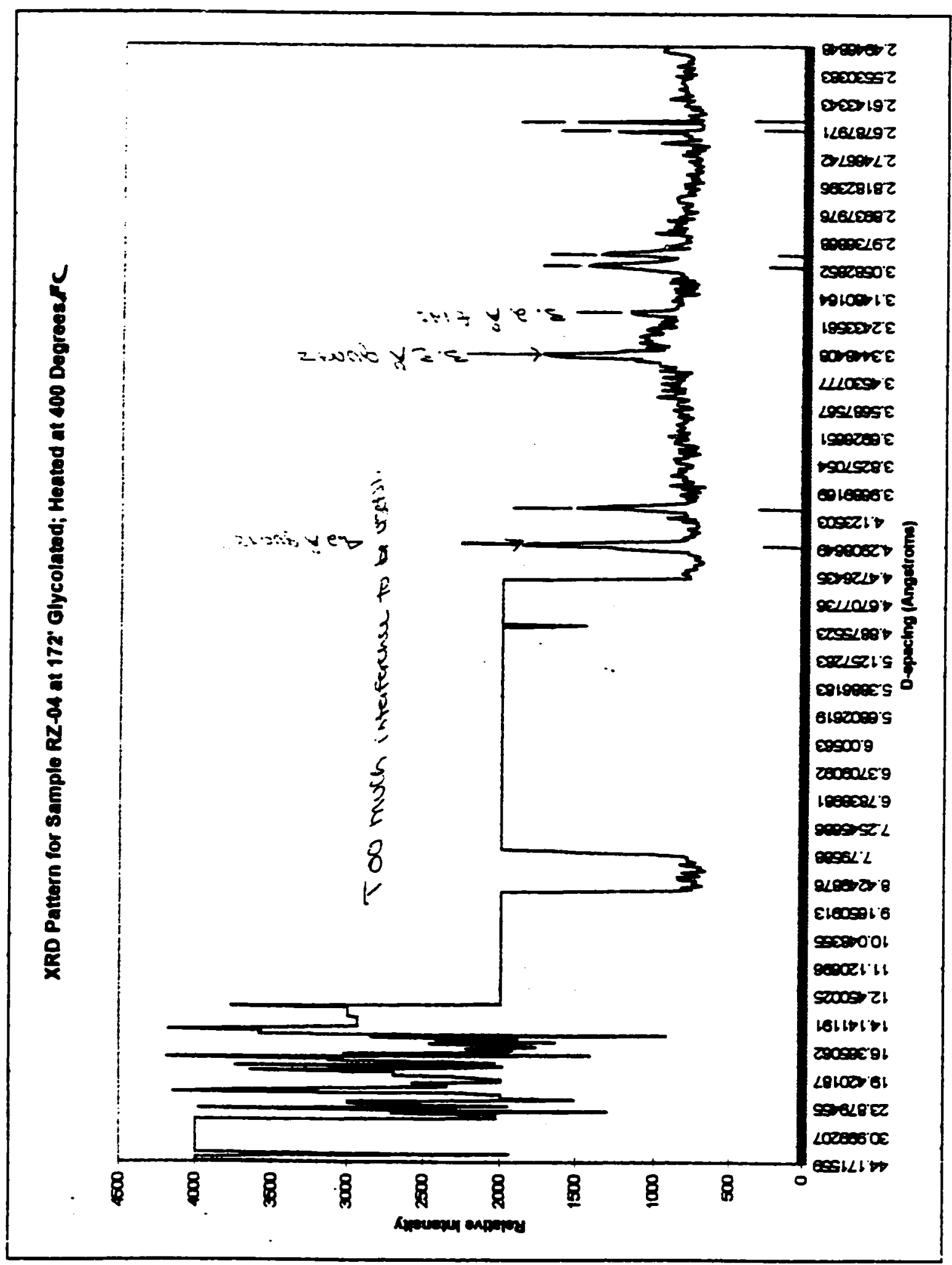




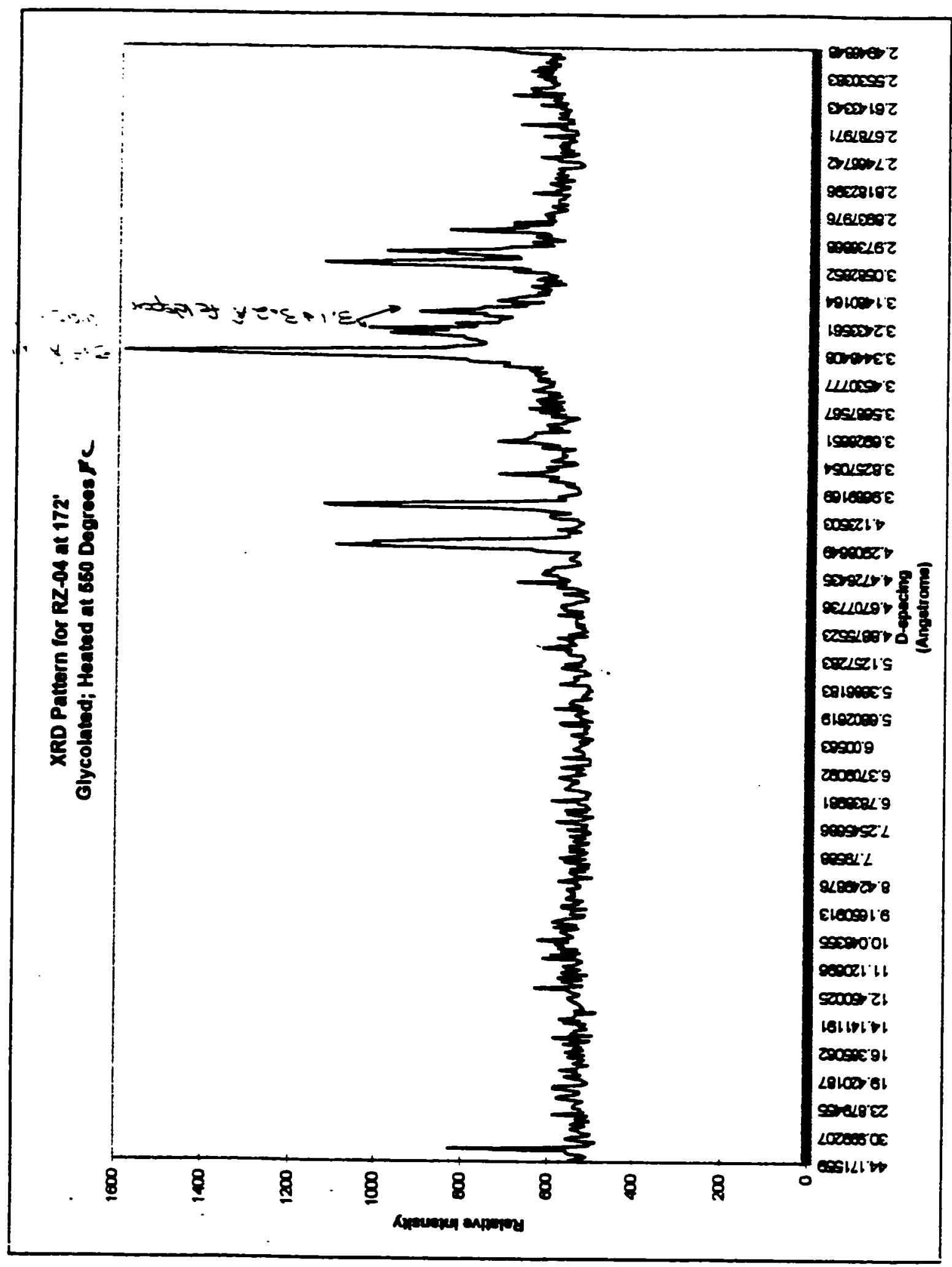




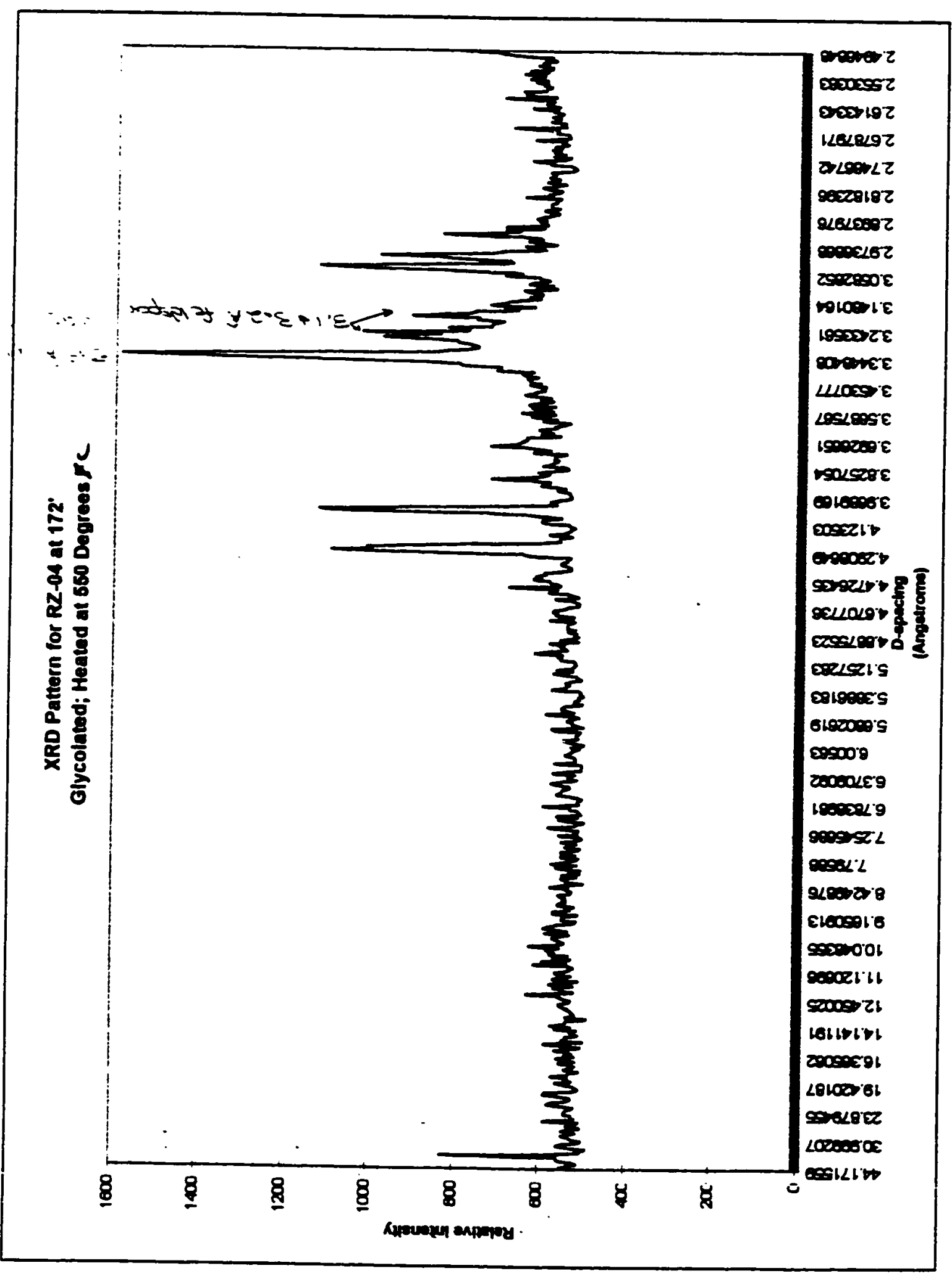


Appendix C

Thin Section Point Counting Data Sheets 

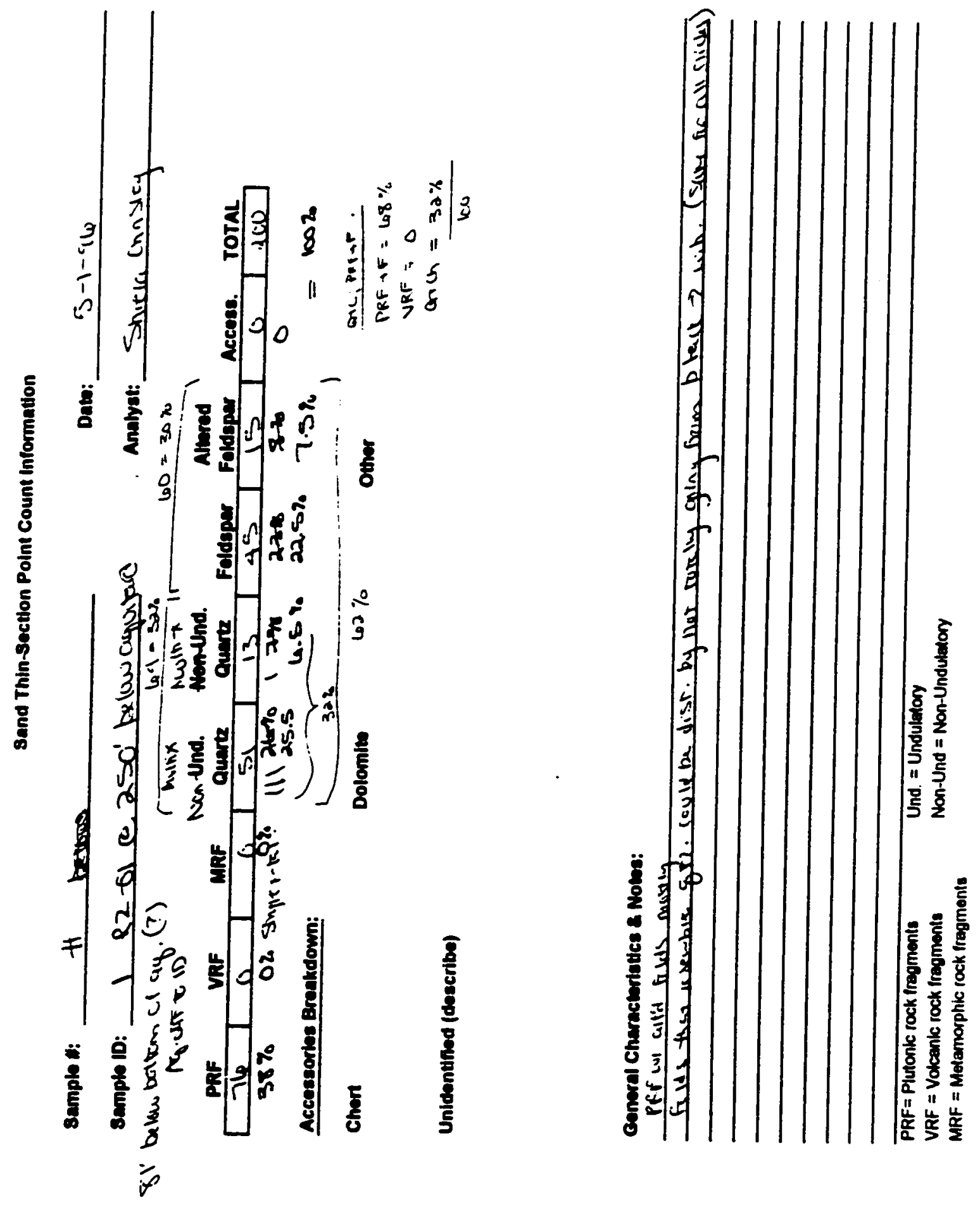


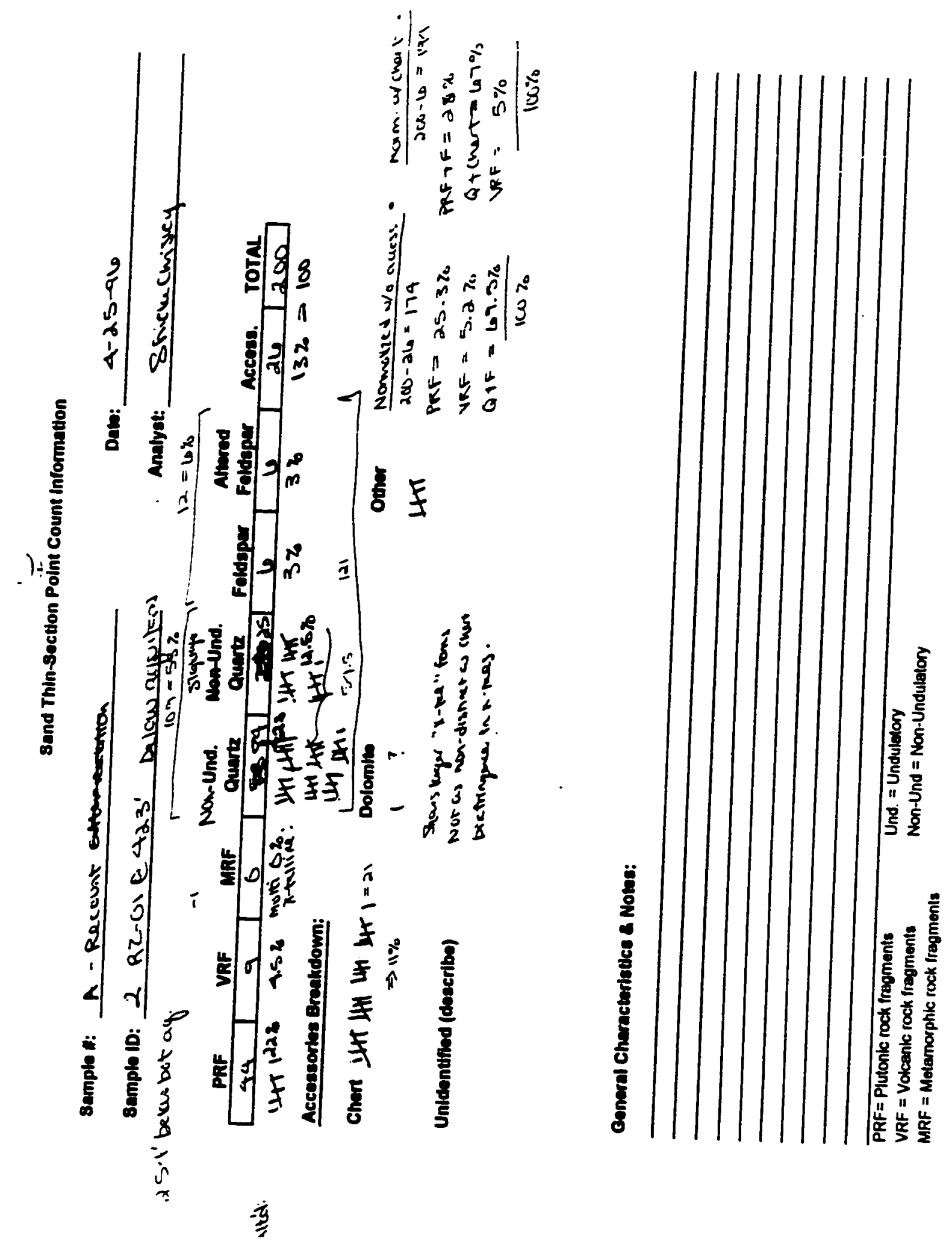




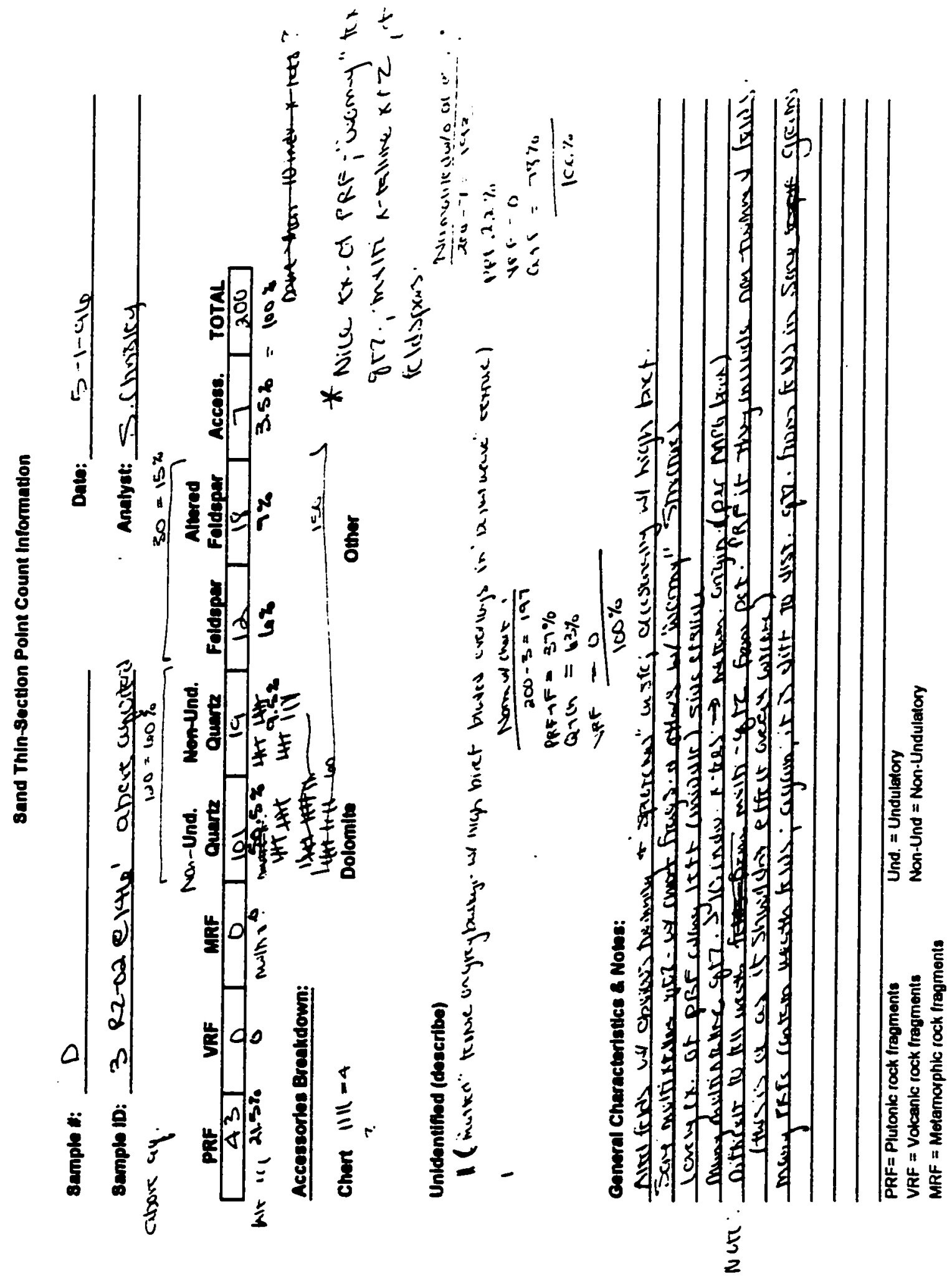




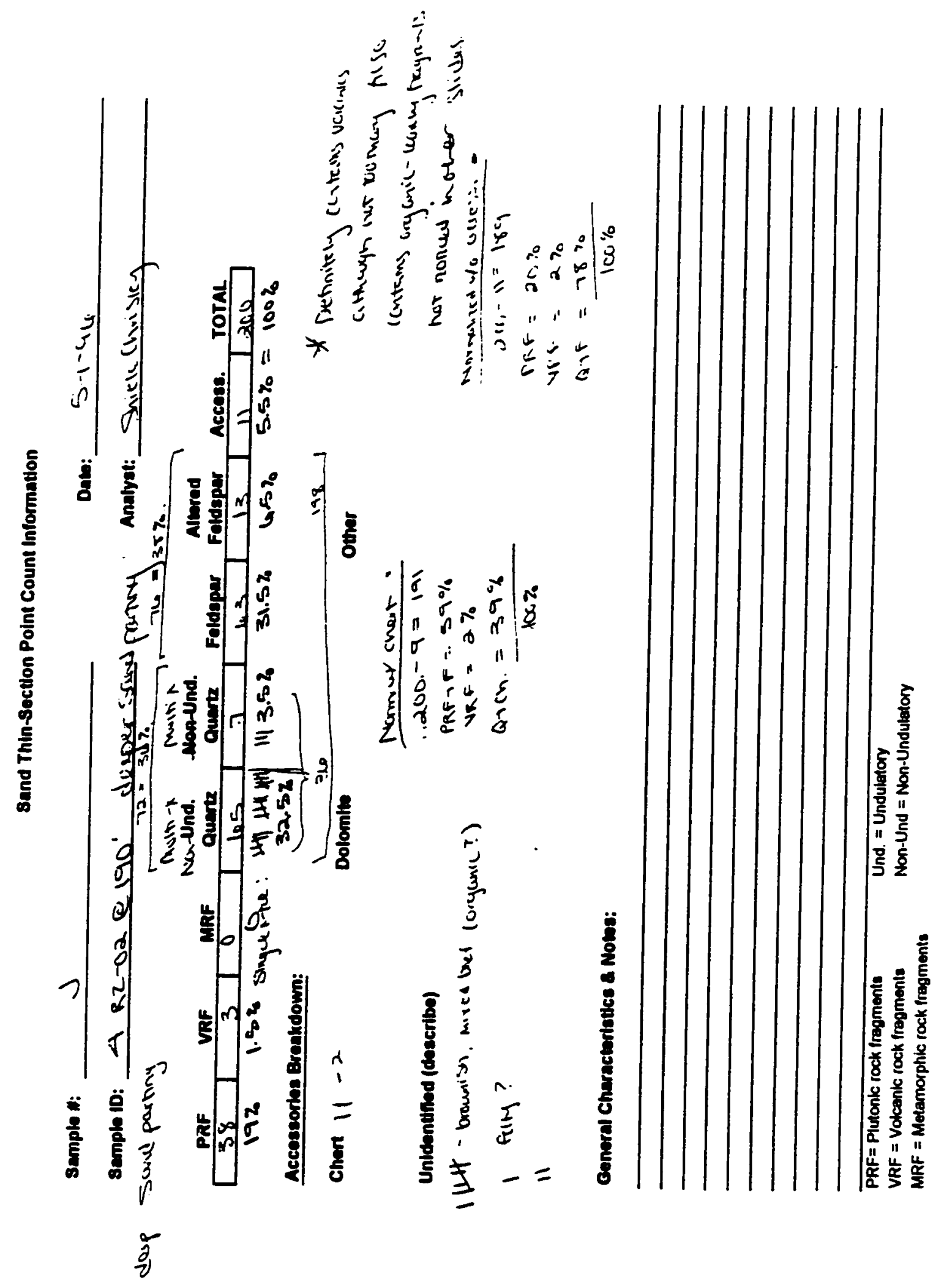



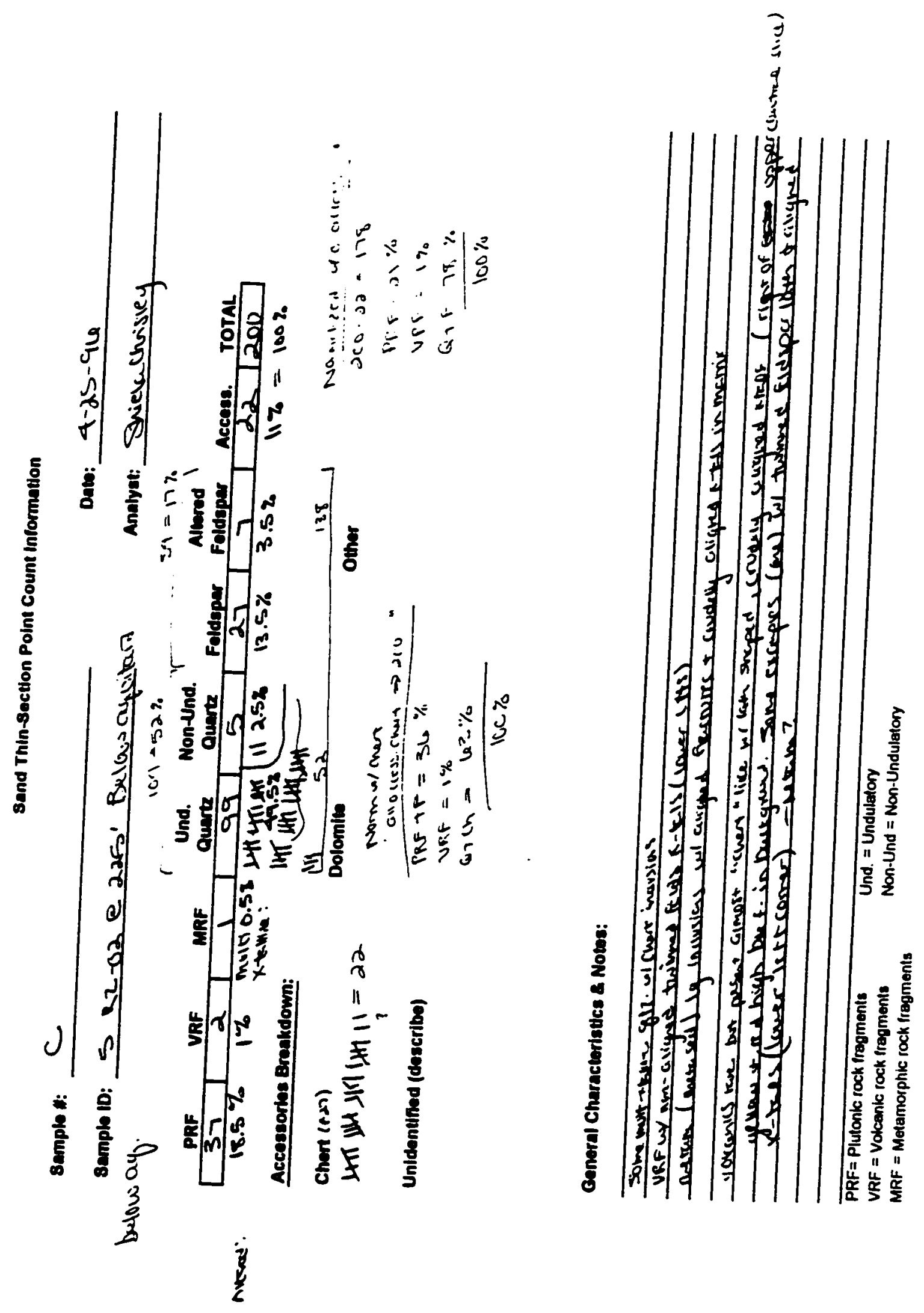

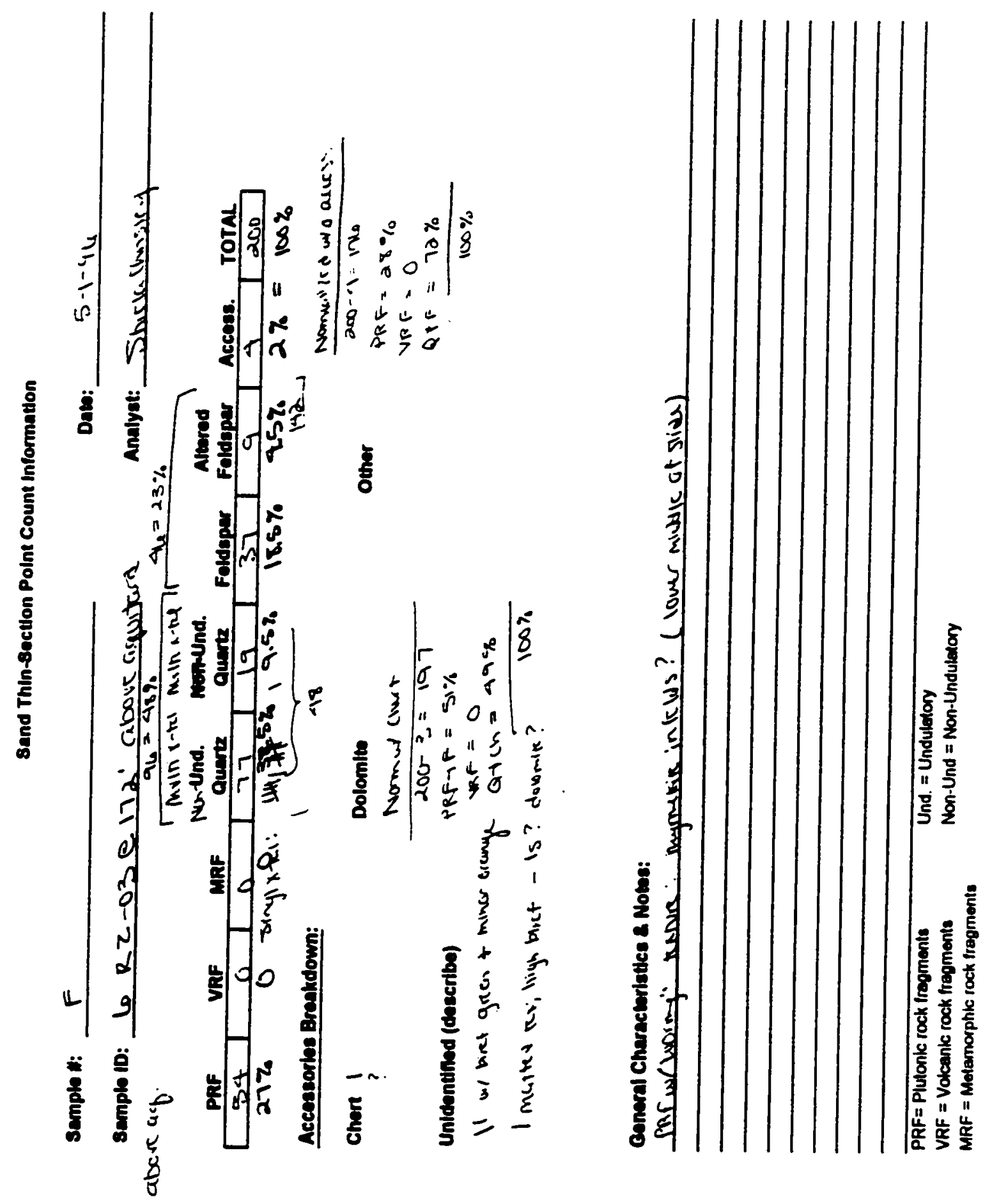


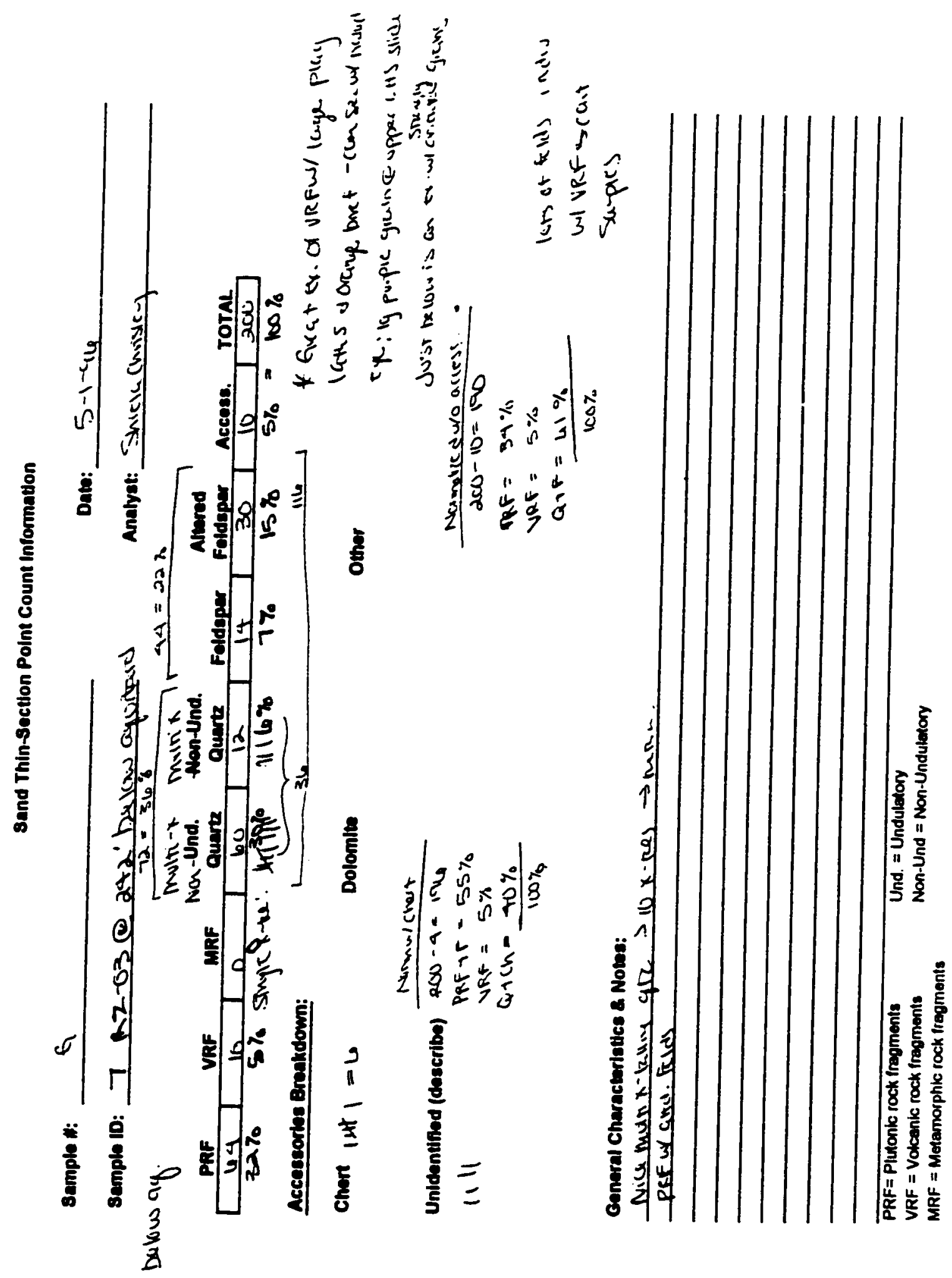



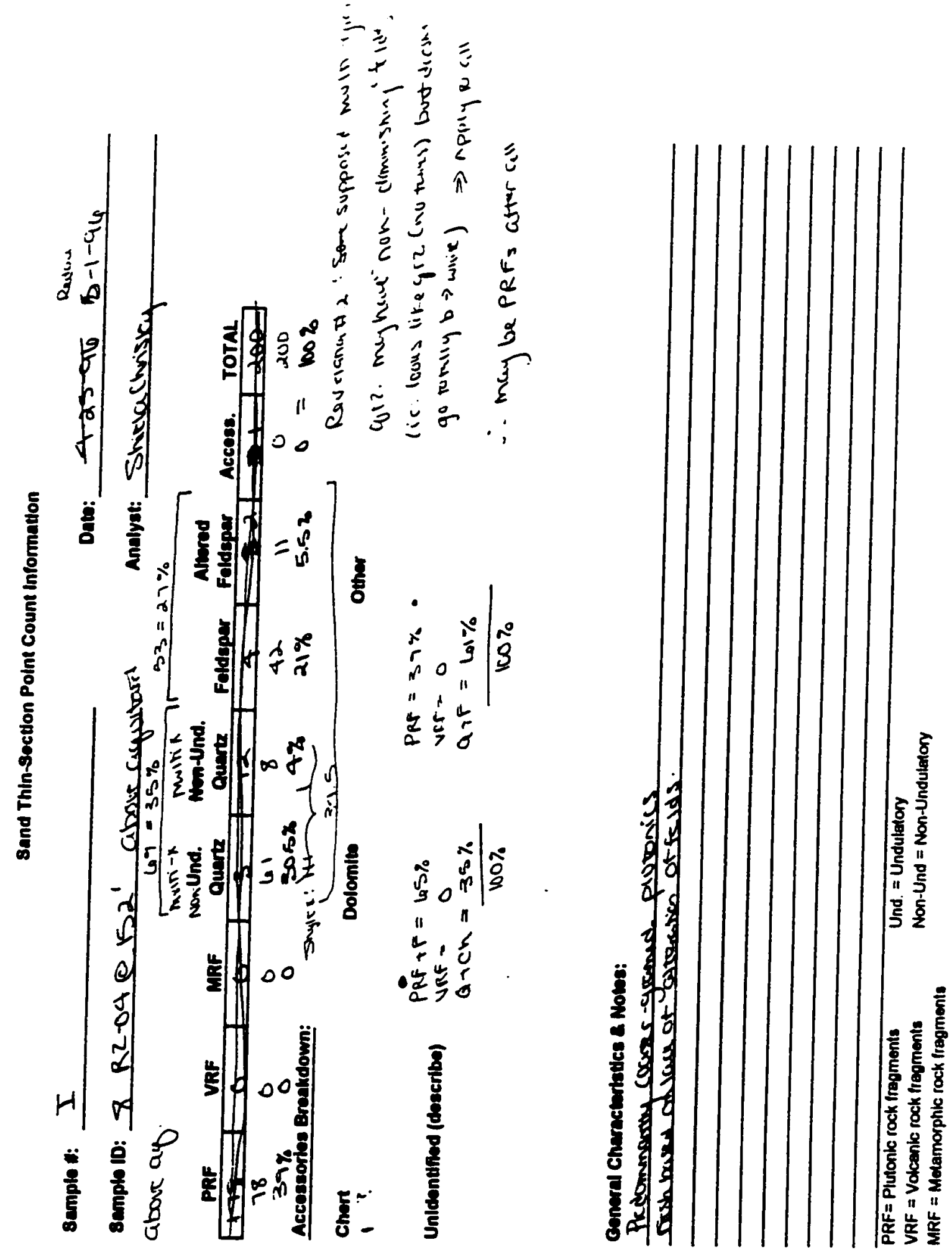

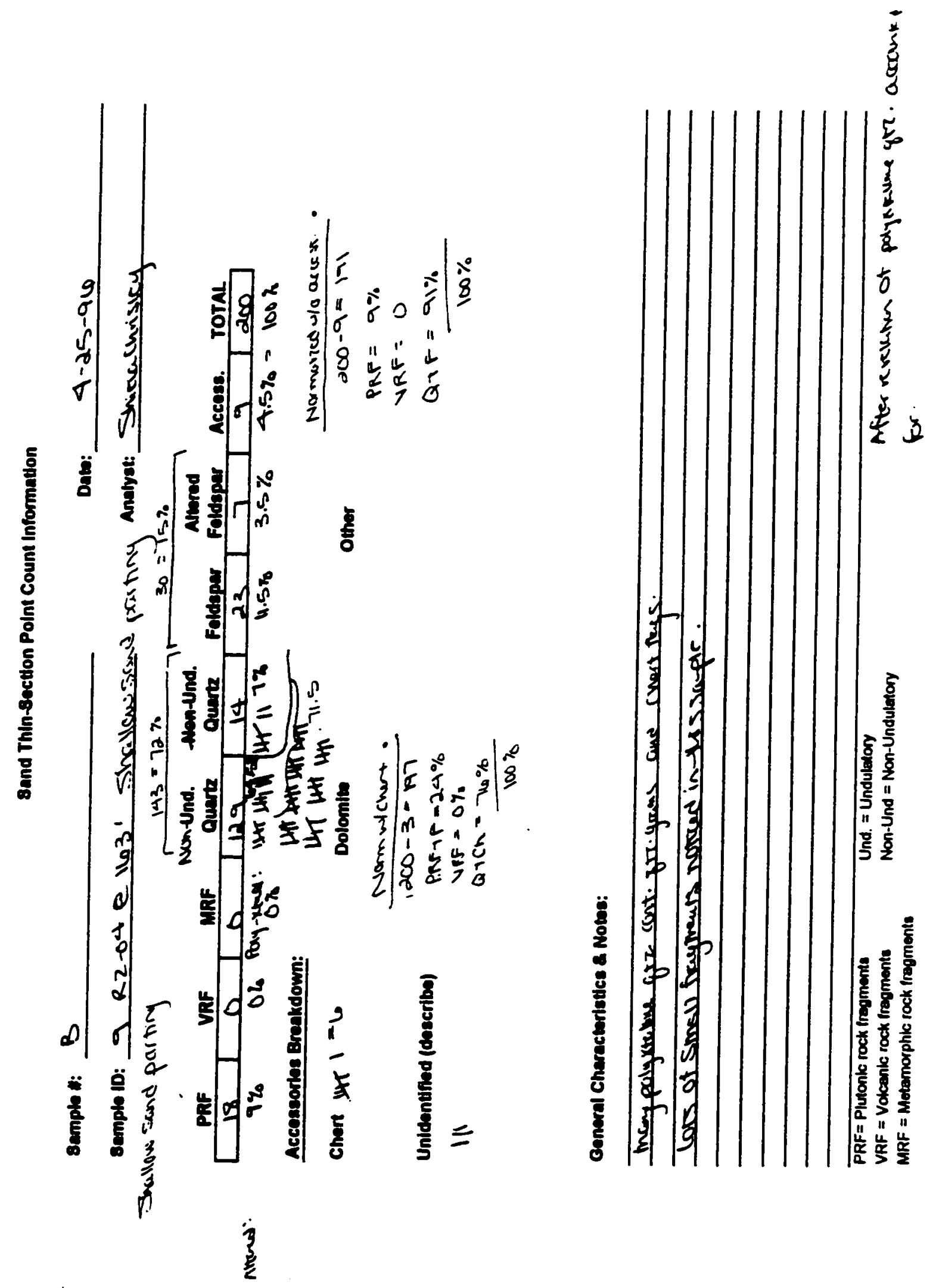


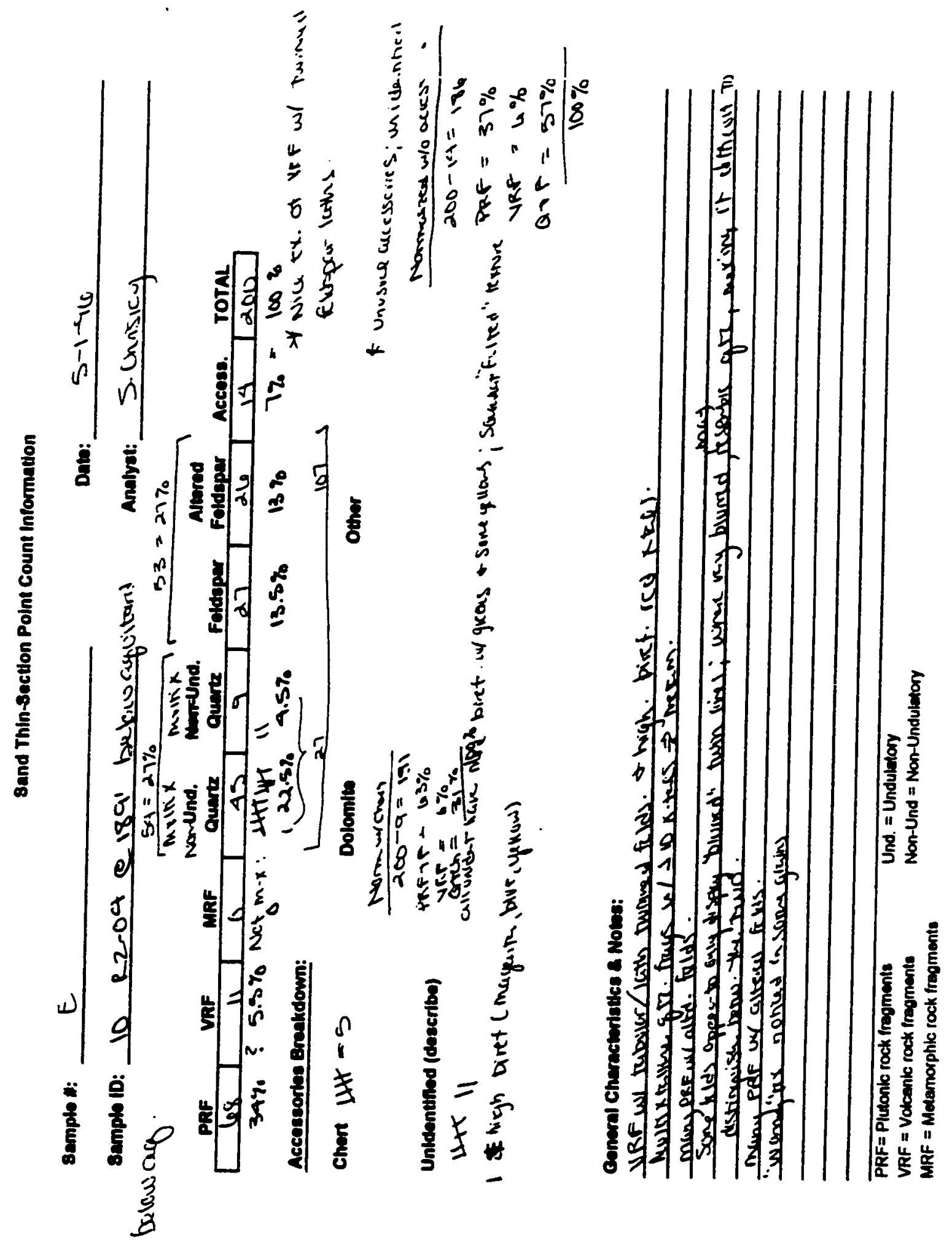

